
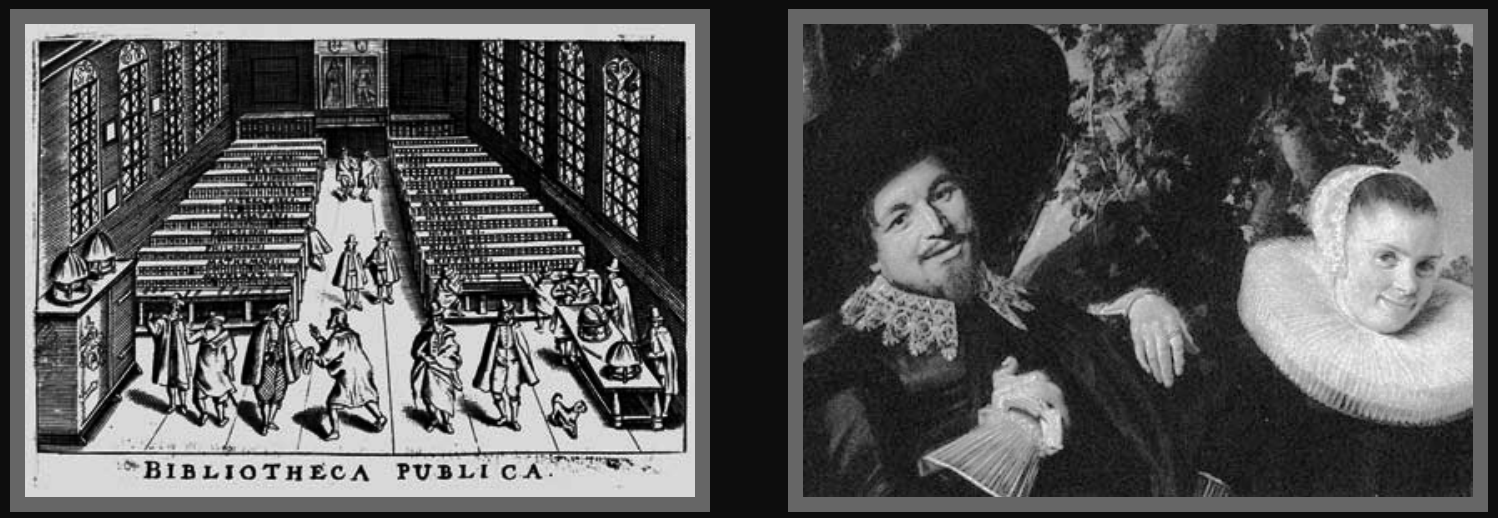

\title{
THIJS POLLMANN
}

\section{De letteren als}

\section{wetenschappen}
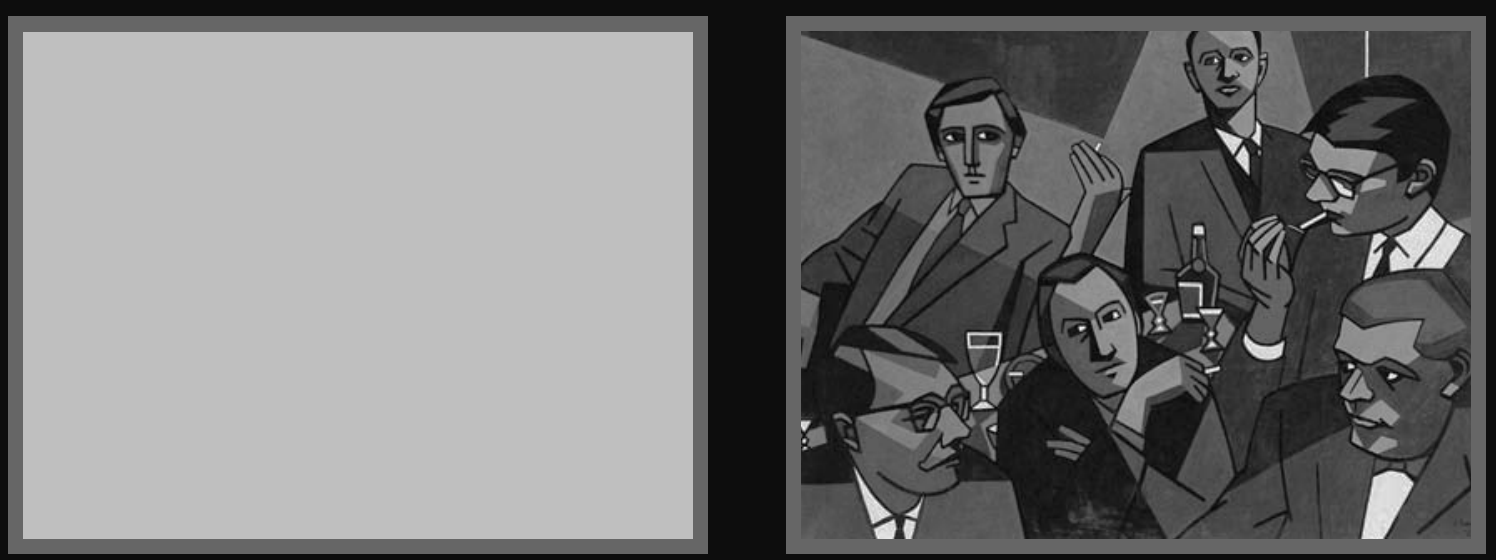
De letteren als wetenschappen 

Thijs Pollmann

\section{De letteren als wetenschappen een inleiding}

Amsterdam University Press 
Omslagontwerp: Kok Korpershoek, Amsterdam

Typografie: Adriaan de Jonge, Amsterdam

NUGI 941

IS BN 9053563938

(C) Amsterdam University Press, Amsterdam, 1999

Alle rechten voorbehouden. Niets uit deze uitgave mag worden verveelvoudigd, opgeslagen in een geautomatiseerd gegevensbestand, of openbaar gemaakt, in enige vorm of op enige wijze, hetzij elektronisch, mechanisch, door fotokopieën, opnamen of enige andere manier, zonder voorafgaande schriftelijke toestemming van de uitgever.

Voor zover het maken van kopieën uit deze uitgave is toegestaan op grond van

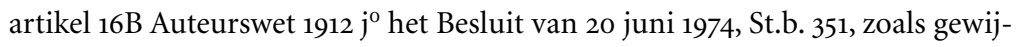
zigd bij het Besluit van 23 augustus 1985, St.b. 471 en artikel 17 Auteurswet 1912, dient men de daarvoor wettelijk verschuldigde vergoedingen te voldoen aan de Stichting Reprorecht (Postbus 882, 1180 AW Amstelveen). Voor het overnemen van gedeelte(n) uit deze uitgave in bloemlezingen, readers en andere compilatiewerken (artikel 16 Auteurswet 1912) dient men zich tot de uitgever te wenden. 


\section{Inhoudsopgave}

\section{Voorwoord 7}

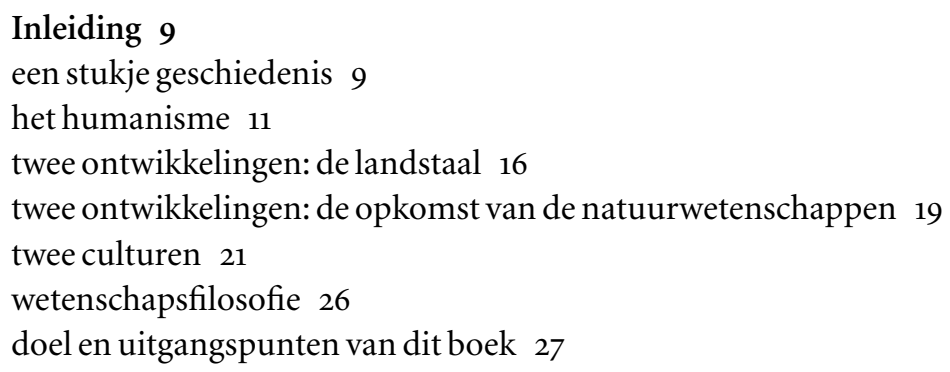


Onderzoekers op zoek naar de waarheid 102 verklaren 1102 een voorbeeld 105 verklaren 2108 onderzoekers zoeken samenhang: begrijpen 110 ordening 116 begrip door classificeren en toetsing aan een norm 117 begrip door classificatie en conceptvorming 121 modellen 123 wetenschap en waarheid 128

6 7 7.1 7.2 $7 \cdot 3$ 7.4 7.5

8 8.1

8.2

8.2.1

8.2.2

8.2 .3

\section{Coherentie 130}

Opvattingen over kennis en de groei van kennis 140 Karl Popper 142

Thomas Kuhn 150

Imre Lakatos 154

Susan Haack 157

groei van kennis 161

De waarde van kennis 171

de geesteswetenschappen en de andere wetenschappen 174 de waarde van geesteswetenschappelijke kennis 176 de waarde van taalkundige kennis 177 de waarde van historische kennis 180 de waarde van de wetenschappelijke kennis over de kunsten 190

Bibliografie 197

Index 205 


\section{Voorwoord}

Dit boek beoogt een aantal theoretische aspecten van de wetenschappen te presenteren. Dit gebeurt aan de hand van ontwikkelingen, werkwijzen, problemen en discussies in de letterenvakken. Er is niet voor deze opzet gekozen omdat deze vakgebieden zich op een bijzondere wijze als wetenschap van de andere wetenschappen onderscheiden. De opzet heeft een didactische bedoeling: voor studenten in de letteren wordt de entree in wetenschapstheoretische problemen vereenvoudigd, als het illustratiemateriaal afkomstig is uit hun eigen vakken.

Geprobeerd is steeds die aspecten van de wetenschapsbeoefening te verhelderen waar studenten in de praktijk van hun opleiding mee in aanraking komen, in plaats van een uitzicht te bieden op de - soms moeilijk met die praktijk te verbinden - filosofische posities van de 'grote namen' in het veld. Uiteraard is wel geprobeerd recht te doen aan de relevante problemen die in de wetenschapsfilosofie doorgaans aan de orde zijn. Het tegendraadse, om niet te zeggen chaotische karakter van de discussie over de grondslagen van de geesteswetenschappen mocht uiteraard niet worden veronachtzaamd. Toch achtte ik het niet heilzaam de structuur van het betoog door deze discussies te laten bepalen. Daarom is er voor gekozen de zienswijzen die niet mochten worden overgeslagen, een plaats te geven in illustratieve kaders op verschillende plaatsen in de tekst. Bij de keuze van de voorbeelden van vakbeoefening heb ik mij laten leiden door de gedachte dat belangrijke en invloedrijke prestaties beter tot ondersteuning van het betoog kunnen dienen dan de curieuze mislukkingen of 'losse flodders', maar ook illustraties uit die laatste categorie ontbreken niet geheel.

Ook is gepoogd de wijze van werken in de letterenvakken zoveel mogelijk vanuit dezelfde gezichtspunten te beschrijven, in de veronderstelling dat contrasten tussen de vakken daardoor duidelijker tot uitdrukking kunnen worden gebracht. Tenslotte is het niet zo dat in alle vakken dezelfde methoden gangbaar zijn. De gekozen doelstellingen brengen met zich mee dat, vergeleken met andere inleidingen in de wetenschapstheorie, naar verhouding veel aandacht wordt besteed aan de problemen rond 'interpretatie', aan het verschijnsel coherentie als maat voor succes en aan de talige vorm van kennis. Hoofdstuk 6 en paragraaf 4.2.1. zijn bewerkingen van Pollmann 1995, resp. 1997. 
Ten behoeve van het gebruik van dit boek in het onderwijs wordt in de loop van 1999 een website ingericht. Het ligt in de bedoeling daar een arsenaal aan voorbeelden, een glossarium met hyperlinks, toetsen en quizzes, en interessante discussieplaatsen op het Internet te presenteren. Geïnteresseerden in het gebruik van deze extra-mogelijkheden wordtverzocht contact op te nemen met de auteur Thijs.Pollmann@let.uu.nl

Discussies met en adviezen en commentaar van mijn collega's Truus van Bueren, Maarten van Buuren, Igor Douven, Rob van Gerwen, Lex Heerma van Voss, Ed Jonker, Gert-Onne van de Klashorst, Geert Koefoed, Malcolm de Mowbray, Theo Verbeek en Sytze Wiersma hebben aan de totstandkoming en verbetering van dit boek bijgedragen. Gedachtenwisselingen met collega's uit verschillende vakgebieden van de letterenfaculteit in Utrecht en met studenten Algemene Letteren hebben grote invloed gehad op de keuze van de stof, de voorbeelden en de presentatie. Ik ben allen daar zeer erkentelijk voor. Dank ben ik ook verschuldigd aan Lex Heerma van Voss voor de toestemming enkele fragmenten uit een syllabus in aangepaste vorm in dit boek te gebruiken. Uiteraard ben ik alleen verantwoordelijk voor alle tekortkomingen die zijn overgebleven. Ik houd me aanbevolen voor op- en aanmerkingen over inhoud en vorm die aan verdere verbetering van de tekst kunnen bijdragen.

Utrecht, januari 1999 
In dit hoofdstuk komen twee onderwerpen aan de orde. Allereerst gaat de aandacht uit naar enkele facetten van de ontwikkeling van de wetenschappen. In het bijzonder zullen we daarbij letten op de positie van de humaniora, de vakken die we hier en elders ook als letteren, alfa-vakken of geesteswetenschappen zullen aanduiden. We zullen ook een poging doen de humaniora te karakteriseren. Daarbij doemt de vraag op of de verschillende wetenschappen kenmerken gemeenschappelijk hebben. Als een begin van een antwoord op die vraag maken we kennis met het vak dat zich bezighoudt met de theorie van de wetenschappen. Dat is het tweede onderwerp van dit hoofdstuk. In dat kader komen het doel en de theoretische uitgangspunten van dit boek aan de orde.

1.1

drie wetenschapsgebieden...

... en hun propedeuse

\section{Een stukje geschiedenis}

Rond het jaar 1200 ontstonden in Parijs, Oxford en Bologna de eerste universiteiten. Die universiteiten kenden vier faculteiten: drie voor de 'hogere' wetenschapsgebieden, de theologie, de medicijnen en de beide rechten, het wereldlijke en het kerkelijke; de vierde was de zgn. artes-faculteit, die soms ook filosofische faculteit werd genoemd.

De artes - of vollediger de artes liberales - waren de vakken die al aan het begin van onze jaartelling de opleiding van de aanzienlijke Romeinen uitmaakten. Het waren die vaardigheden of kundes die typerend waren voor vrije mensen, mensen dus die geen slavenwerk hoefden te doen. De artes worden in de Middeleeuwen op de Latijnse scholen onderwezen, maar ook aan de universiteiten. Daar vormen ze de propedeuse. De vakken waren onderverdeeld in het trivium (de drieweg) en het quadrivium (de vierweg). Tot het trivium behoorden de grammatica (Latijn, d.w.z. de taal en de letterkunde), de dialectica (de redeneerkunst) en de retorica (de welsprekendheid). De muziek, de astronomie, de rekenkunde en de meetkunde vormden samen het quadrivium.

De artes-faculteit verzorgde ook het onderwijs in de filosofie, die als een soort bekroning van de artes-studie gold. Maar ook de filosofie was een propedeutisch vak: een student studeerde af in de theologie, de rechten of de medicijnen. 
gezaghebbende teksten vormden de leerstof

de teksten werden van commentaar voorzien

universiteiten en wetenschapsbeoefening

'beroepsperspectieven'
Universiteiten in de Middeleeuwen waren in de eerste plaats onderwijsinstellingen. Alle colleges werden gegeven in het Latijn. De leerstof werd gevormd door gezaghebbende teksten. Dat waren voor het merendeel teksten die toen al meer dan duizend jaar oud waren. Het volgende geeft een indruk van de werken die behandeld werden.

- voor de theologie bestudeerde men natuurlijk de Bijbel - in de Latijnse vertaling van Hiëronymus - en daarnaast de werken van belangrijke vroegchristelijke schrijvers, de zgn. kerkvaders, zoals bijvoorbeeld Augustinus (354-430 na Chr.);

- voor de geneeskunde was er het via het Arabisch overgeleverde werk van de van origine Griekse, maar vooral in Rome werkzame arts Galenus (130-ca. 210 na Chr.);

- voor het wereldlijke recht gebruikte men het werk van Justinianus (482-565 na Chr.); en voor het kerkelijke het Corpus Iuris canonici dat vanaf de twaalfde eeuw hoe langer hoe vaster vorm kreeg.

- voor de artes waren er ook zulke teksten. Als grammatica gebruikte men eeuwenlang het boek van Donatus ( $4^{\mathrm{e}}$ eeuw na Chr.). Het werk van Cicero (106-43 voor Chr.) was van bijzonder belang voor de retorica, en voor de meetkunde was er Euclides ( \pm 300 voor Chr.). De gevorderden bestudeerden de werken van de Griekse filosoof Aristoteles (384-322 voor Chr.). Die worden in de twaalfde eeuw in de westerse wereld herontdekt via het werk van Arabische auteurs. Aristoteles' werken bestrijken een groot aantal gebieden: de logica, de ethiek, de natuurfilosofie, de biologie en de taal- en letterkunde.

In de colleges werden de gezaghebbende teksten soms op een zeer gedetailleerd niveau van commentaar voorzien. Men gaf verklaringen van de betekenis en de herkomst van woorden, een verheldering van grammaticale eigenaardigheden, en uitleg over de in de tekst genoemde mythologische, historische of literaire figuren en de gebeurtenissen waarin ze waren verwikkeld.

Geleerden streefden in het algemeen niet naar uitbreiding van kennis, bijvoorbeeld door een systematische studie van de werkelijkheid of door het doen van experimenten. Dit hing samen met het goddelijke gezag dat aan de Bijbel werd toegekend, en aan de hoge status die de eeuwenoude klassieke teksten bezaten. Als er in de vroege universiteiten van kennisvermeerdering kan worden gesproken, gaat het in de eerste plaats om nieuwe interpretaties of om een nieuwe systematisering van de kennis die in de teksten vervat is. Als de grootste prestatie op dit gebied geldt de integratie van het werk van Aristoteles in het christelijke denken. Daar zijn de namen aan verbonden van de theologen Albertus Magnus (rond 1200-1280) en Thomas van Aquino (1225-1274).

De 'hogere' universitaire wetenschapsgebieden, de theologie, de rechten en de medicijnen, vormden de fundamenten voor drie beroepen. 10 
Wie 'bedienaar van Gods woord', 'priester' of 'geestelijke' (in de hogere rangen) wilde worden, studeerde theologie. Wie medicijnen had gestudeerd, werd arts. En iemand die opgeleid was in de beide rechten kon gaan werken bij rechtbanken en in de advocatuur, maar was daartoe toen net als nu niet beperkt. Het vierde gebied, dat van de artes en de filosofie, was propedeutisch en had niet het karakter van beroepsvoorbereiding. Wilde men met deze vakken zijn brood verdienen, dan moest men promoveren in een van de hogere opleidingen, en zelf les gaan geven.

1.1 .1

studia humanitatis

de vakkennis van de humanisten

kennis van taal en geschiedenis gaan hand in hand
Het humanisme

In de late veertiende eeuw, begin vijftiende eeuw vormt zich in Italië een nieuw soort 'opleiding' die studia humanitatis werd genoemd. In het klassieke Rome had onder die naam ook al zo'n opleiding bestaan. De term is bewaard gebleven in het Engelse woord 'humanities' en verwant aan het Nederlandse begrip 'humaniora'.

'Humanitas' is het Latijnse woord voor 'mens zijn', en bij uitbreiding voor '(menselijke) cultuur' als tegenstelling van '(menselijke) natuur'. De naam studia humanitatis bracht tot uitdrukking dat de studie in het bijzonder gericht was op de ontwikkeling van menselijke waardigheid en geëigend was voor de opvoeding tot een ontwikkeld en respect afdwingend menselijk persoon.

De nieuwe studie die zowel het programma van de Latijnse scholen als van de propedeuse in de universiteiten ging doordringen, omvatte grammatica (van het Latijn), retorica, geschiedenis en ethiek, alles gecentreerd rondom de 'bonae litterae', de schone letteren, de literatuur. (Kristeller 1979: 22) Dit conglomeraat van vakken was het terrein van geleerden die onder studenten in Italië umanista, 'humanist', werden genoemd.

De humanisten werden de experts in de omgang met 'oude', 'klassieke' teksten. Ze beheersten niet alleen het Latijn, maar ze kenden (vanaf de vijftiende eeuw in toenemende mate) ook Grieks, soms ook Hebreeuws, Arabisch etc. Deze talenkennis maakte het mogelijk dat ze zeer veel manuscripten weer aan het daglicht brachten, die tot de belangrijkste behoorden van hetgeen de klassieke beschaving heeft opgeleverd, maar die geheel vergeten waren, of slechts bij naam bekend. De humanisten werden daardoor bij uitstek de beheerders van het literaire, wetenschappelijke en filosofische erfgoed uit de Griekse en Romeinse tijd.

Kennis van geschiedenis en kennis van talen en letterkunde (filologie) gaan bij de humanisten hand in hand. Door hun historische kennis konden de humanisten laten zien dat een tekst pas goed tot zijn recht komt, als die in de context van zijn ontstaan wordt geïnterpreteerd. En tekstinterpretatie leverde weer zuiverder historische inzichten op. 
retorica maakt de studie toepasbaar

in de studia humanitatis is een echte letterenopleiding herkenbaar

invloed van het humanisme
De humanisten ontdekten dat de manuscripten van dezelfde tekst niet allemaal hetzelfde zijn; dat sommige manuscripten 'corrupt' zijn, dat er verschrijvingen in staan, dat er teksten zijn die wel aan beroemde auteurs werden toegeschreven, maar helemaal niet door die auteurs geschreven konden zijn. Kortom, ze lieten zien dat sommige manuscripten onbetrouwbaar zijn. Ze waren de 'uitvinders' van de tekstkritiek, de kennis en methode waarmee kan worden bepaald welke overgeleverde vorm van een tekst de meest authentieke is. Voor een cultuur waarin men geneigd was voor waar te houden wat geschreven was, was dat een bijzonder belangrijke en verstrekkende ontdekking. (Grafton 1991)

In de samenleving vormde de retorica het meest bruikbare onderdeel van de studia humanitatis. Dit vak omvatte de vaardigheid het woord te voeren in openbare en besloten bijeenkomsten en de vaardigheid in het schrijven van persoonlijke en zakelijke teksten, vaak brieven. Kennis van de grote klassieke culturele voorbeelden, kennis van mythologische figuren en historische persoonlijkheden en gebeurtenissen, in de studie tot handzame brokjes wijsheid verwerkt, konden in zulke redevoeringen en teksten worden opgediend, en zo de overtuigingskracht en de uitstraling ervan ondersteunen. De klassieke letteren, de werken van Cicero en Ovidius bijvoorbeeld, leverden de gecultiveerde en tot navolging strekkende grote voorbeelden in alle mogelijke genres en voor alle mogelijke gelegenheden.

Kennis van vreemde talen, kennis van geschiedenis, van literatuur en kennis van de retorica, de mondelinge en geschreven taalbeheersing: het zal niet veel moeite kosten in deze studia humanitatis een echte letterenopleiding te herkennen.

Maar juist het propedeutische karakter maakt al duidelijk dat de humanistische geleerdheid verderstrekkende effecten had. De andere vakgebieden hadden de nauwkeurige en verantwoorde analyse en interpretatie van die teksten nodig. Het humanisme leverde die. Humanisten vond men na verloop van tijd niet alleen in Italië, maar ook overal elders in West-Europa. Bijna alle geleerden - van welk vakgebied dan ook - waren in de zestiende en zeventiende eeuw humanisten. Het soort geleerdheid dat de humanisten zich eigen maakten en in de studie overdroegen, kwam tot groot aanzien. Op de culturele beweging die wij Renaissance noemen en op de godsdienstige omwenteling die Reformatie heet, hebben zij een grote invloed uitgeoefend. *

Scholing in de humanistische vakken werd synoniem met 'een goede opvoeding'. De vakken groeiden daardoor in aanzien. De humanisten

* Het humanisme waarover hier wordt gesproken, was een vorm van geleerdheid, een cultureel en educatief programma, en moet niet verward worden met de hedendaagse levensbeschouwing zoals die door het Humanistisch Verbond wordt belichaamd. 
de studia humanitatis blijft organisatorisch ondergeschikt aan de 'hogere' vakgebieden kregen door de aard van het onderwijssysteem en hun vakkennis een grote invloed op het onderwijs zelf, zowel dat van de Latijnse scholen als van de universiteiten.

Desondanks, om af te studeren aan een universiteit, om 'doctor' te worden moest men afstuderen in de theologie, de medicijnen of de rechten. Deze eis, gevoegd bij de grote vrijheid van de student om het humanistische deel van de opleiding in veel verschillende richtingen uit te breiden, leidde tot een brede geleerdheid en tot academische loopbanen die ons grillig voorkomen. De bijgaande voorbeelden van opleiding en loopbaan van beroemde Nederlandse humanisten kunnen dit illustreren.

\section{Opleiding en loopbaan van enkele Nederlandse humanisten}

Erasmus (1469?-1536) - volgens sommigen de grootste humanist aller tijden - leerde Latijn aan de kloosterschool in Gouda, werd priester en studeerde theologie en Grieks in Parijs. Hij was een tijdlang secretaris van de bisschop van Kamerijk. Hij publiceerde naast veel ander theologisch werk de Griekse tekst van het Nieuwe Testament (dat deel van de Bijbel dat het leven en de leer van Jezus beschrijft) met de Latijnse vertaling ernaast. Die Griekse tekst was ouder en authentieker. Erasmus werd beroemd bij een groot publiek met de Adagia, een verzameling van op het laatst meer dan 4000 spreekwoorden en zegswijzen. Hij legde uit hoe ze bij de klassieke auteurs werden gebruikt, welke levenswijsheid er in verborgen was. De verzameling beleefde talloze herdrukken. De Adagia betekenden voor een groot publiek een venster op de praktische levenswijsheid van de klassieken.

Justus Lipsius (1547-1606) was achtereenvolgens hoogleraar in de geschiedenis en de filosofie in Jena, in de geschiedenis en de rechten in Leiden, en in de geschiedenis en het Latijn in Leuven. Hij was hofhistoricus van de koning van Spanje. Zijn hoofdwerk De Constantia is een ethisch-filosofisch werk.

Gerard Vossius (1577-1649) studeerde theologie, werd hoogleraar in de retorica en het Grieks in Leiden, promoveerde te Oxford in het wereldlijk recht en werd hoogleraar in de geschiedenis te Amsterdam.

Caspar Barlaeus (1584-1648) was opgeleid als theoloog, behaalde een graad in de medicijnen en werd hoogleraar in de logica, eerst in Leiden, later in Amsterdam. Hij aanvaardde daar zijn ambt met een ethisch-filosofische rede over de Wijze Koopman. 


\section{Een voorbeeld van een Erasmiaans adagium}

'Het hemd is nader dan de rok.

Bij Plautus [...] staat de spreekwoordelijke metafoor: de tunica is nader dan het pallium. Daarmee wordt bedoeld dat men tegenover sommige vrienden meer verplichtingen heeft dan tegenover anderen, en dat niet allen gelijke aanspraak op hulp kunnen maken.

Voor de mensen in de antieke wereld had men in de eerste plaats verplichtingen tegenover de ouders en meteen daarna kwamen de aan ons toevertrouwde kinderen, op de derde plaats de cliënten, op de vierde de gasten en op de vijfde de bloed- en aanverwanten. Dit vertelt Gellius in het vijfde boek, hoofdstuk 13. Daarnaast zijn sommige zaken voor ons ook directer van belang dan andere.

Het pallium was bij de Grieken wat de toga was bij de Romeinen, het overkleed. Onder de toga droeg men de tunica. Zo worden ook bij Homerus vaak mantel en overkleed in een adem genoemd.'

(Adagia I 3, 89)

Opleiding, specialisme en vakbeoefening zijn veel breder dan wij gewend zijn. Geleerden konden verschillende gebieden tegelijkertijd beheersen. Omdat de humanistische vakken propedeutisch waren, had iedereen er in ieder geval mee kennisgemaakt. Omdat de studieprogramma's vrij waren, kon men ze ook op gevorderd universitair niveau beoefenen, en daardoor konden ze ook de beoefening van de 'hogere opleidingen' blijven beïnvloeden. Dat gold ook voor de combinatie van de humaniora met een beoefening van wiskunde, natuurkunde, biologie en astronomie. Golius, rond 1650 de Leidse hoogleraar in het Arabisch, gaf colleges in de wiskunde. En het werk van Joseph Justus Scaliger op het gebied van de tijdrekening is niet denkbaar zonder een bijkans universele kennis op het gebied van de klassieke en oosterse talen, de astronomie en de geschiedenis.

dubbele positie van de artes in het onderwijsstelsel

nieuwe ontwikkelingen
De universitaire gespecialiseerdheid in de humanistische vakken kon ook daarom groeien, omdat de Latijnse scholen een hoe langer hoe groter deel van de propedeutische vorming voor hun rekening gingen nemen. Sommige van de artes-vakken daalden daarmee in status om plaats te maken voor nieuwe specialismen. Nog altijd kan men in onze cultuur die enigszins dubbelzinnige positie van de artes-vakken terugvinden: enerzijds voorbereidend en algemeen vormend, anderzijds voedingsbodem voor de studie van hoog aangeschreven cultuurproducten.

Aan de geprivilegieerde positie van het Latijn en van de humanistische vakgebieden wordt in de zestiende, zeventiende en achttiende eeuw beetje bij beetje geknaagd door nieuwe ontwikkelingen. We bespreken 


\section{Humanistische geleerdheid, Scaliger (1540 - 1609)}

Scaliger had een opmerkelijk talent voor filologie en tekstkritiek. Zijn belangstelling gold niet zozeer klassieke literaire werken, als wel teksten op andere vakgebieden. Zo hield hij zich bezig met het uitgeven en becommentariëren van een Latijns woordenboek uit de tweede eeuw na Christus dat in zeer veel verschillende versies was overgeleverd, en dat een belangrijke bron van kennis was voor het interpreteren van de teksten op het gebied van het Romeinse recht. Bij het bezorgen van een tekst van Hippocrates, de beroemde Griekse medicus, claimde hij dat een filoloog beter in staat was zo'n medische tekst te interpreteren dan de medici die niks van grammatica, woordgeschiedenis en de geschiedenis van tekstoverlevering afweten. Dit soort arrogantie maakte hem berucht bij andere geleerden.

Later ontwikkelde Scaliger een grote belangstelling en kennis van de verschillende systemen van tijdrekening. Dat was een actueel onderwerp. In 1582 voerde Paus Gregorius XIII de moderne zgn. Gregoriaanse kalender in. Het was een aanpassing van de kalender uit de tijd van Julius Caesar, de eerste eeuw voor onze jaartelling.

Grieken en Romeinen, Egyptenaren en Joden, Babyloniërs en Perzen, het Christendom en de Islam hadden allemaal in de loop van hun geschiedenis een of meer systemen ontwikkeld om de tijd in te delen, in jaren en in maanden. De meeste van die systemen konden slechts langs omwegen uit oude teksten worden gereconstrueerd. Hoe de maanden of speciale dagen heetten, was vaak wel bekend, maar het was moeilijk om te bepalen welke plaats in het jaar ze hadden. Ofschoon al die systemen gebaseerd waren op de omlooptijden van zon en maan, waren ze toch allemaal verschillend. Jaren en maanden begonnen niet op dezelfde dag, en duurden niet even lang. Een nieuwjaarsdag in de ene cultuur was niet de nieuwjaarsdag in een andere. Door verslagen van zons- en maansverduisteringen in oude teksten te relateren aan berekende verduisteringsdata slaagde Scaliger er in een heel nieuw samenhangend overzicht te geven van de belangrijkste jaartallen van de geschiedenis van het Nabije en Midden-Oosten en de Joodse, de klassieke en de vroegchristelijke cultuur. Hij unificeerde de wereldgeschiedenis.

Scaliger werd in 1592 voor veel geld naar Leiden gehaald. De in 1575 gestichte Leidse universiteit had een 'grote naam' nodig om gerespecteerd te raken. Scaliger werd er research-hoogleraar zonder onderwijstaak, de eerste ter wereld. Studenten die in onderzoek geïnteresseerd waren, begeleidde hij individueel. Ook dat was nog niet eerder vertoond.

Bron: Grafton 1983-1993. 
hiervan speciaal de opwaardering van de landstaal en de opkomst van de natuurwetenschappen. Beide ontwikkelingen zijn overigens door de humanisten in belangrijke mate begunstigd.

1.1 .2

de opwaardering van de landstaal

invloed van praktijkmensen
Twee ontwikkelingen: de landstaal

Nadat Dante Alighieri (1265-1321) nog vóór het ontstaan van het humanisme al had laten zien dat ook zijn Toscaans een volwaardige literaire taal was die als norm voor andere taalgebruikers kon dienen, duurde het voor sommige andere Europese talen tot de zestiende eeuw voordat er een beweging op gang kwam die er naar streefde dat de volkstaal (vaak gekenmerkt door een grote dialectachtige diversiteit) een enigszins gestandaardiseerde spraakkunst en woordenschat zou krijgen, en daardoor ook een eenheid.

De volkstaal was in aanleg natuurlijk een geschikt communicatiemiddel en kennelijk ook een geschikt voertuig van mooi literair werk. In de Lage Landen laten verhalen als de Reinaert en de gedichten van Hadewych dat bijvoorbeeld zien. Maar velen meenden dat de landstaal de functie als algemene taal pas goed zou kunnen vervullen, als de spreektaal opgebouwd en gezuiverd zou worden. De landstaal moest een zekere mate van standaardisering hebben bereikt. Precies zoals het zo bewonderde Latijn. Zoals men zich kan voorstellen, was de boekdrukkunst bij dit streven naar standaardisering een van de drijvende krachten. (Willemijns 1997)

Het streven naar opwaardering van de volkstaal kreeg steun van de humanisten. Erasmus bijvoorbeeld laat in een van zijn dialogen iemand (in het Latijn!) zeggen dat het een schande is als iemand zijn moedertaal niet beheerst. Geen taal is zo barbaars, zegt hij, of zij heeft haar eigen uitdrukkingsvermogen, als ze maar behoorlijk gekuist wordt. (Dibbets 1977: 21).

De behoefte aan de landstaal deed zich ook bij de kennisoverdracht voor, vooral onder 'technici', dat wil zeggen onder 'artist-ingenieurs, schilders, beeldhouwers, architecten, ook zij die kanalen aanleggen, sluizen en vestingwerken ontwerpen en nieuwe werktuigen uitvinden, maar ook instrumentmakers die voor zeevaart, landmeetkunde, astronomie en muziek werkzaam zijn, en klokkenmakers, kartografen en militaire technici', zoals de wetenschapshistoricus Dijksterhuis de categorie omschreef. Ze hadden veelal een vorm van lager onderwijs in de landstaal gevolgd, en hadden geen vakopleiding doorlopen waarin het Latijn de boventoon voerde. De beginselen van hun vak hadden ze meestal bij een leermeester in de praktijk geleerd. Zulke mensen keken anders tegen 'geleerdheid' aan dan de humanisten. De mensen van de praktijk, onder wie 
Engels als lingua franca heroriëntatie van de humaniora we grote namen uit de kunstgeschiedenis vinden, zoals Brunelleschi, Ghiberti, Alberti, Leonardo da Vinci, Benvenuto Cellini en Albrecht Dürer, hadden behoefte aan betere en handiger manieren van rekenen, meten en wegen dan in de gezaghebbende teksten voorhanden waren. Ze ontwikkelden nieuwe werktuigen en wilden weten waarom die werkten zoals ze werkten. Ze waren soms ook gemakkelijker bereid om proefondervindelijk werktuigkundige ideeën uit te proberen dan de universitaire geleerden.

Het bekendste Nederlandse voorbeeld van deze ontwikkeling biedt het werk van Simon Stevin. Mede op instigatie van Stevin ging de Leidse universiteit rond 1600 Nederlandstalig onderwijs verzorgen, en wel in de rekenkunde, de vestingbouwkunde en de (land-)meetkunde. Dit onderwijs in de landstaal overleefde de zeventiende eeuw echter niet. Voor 1700 had het Latijn weer de alleenheerschappij veroverd.

Het Latijn bleef in de wetenschappelijke wereld nog lang dominant. De volgende tabel geeft daarvan een indruk. De getallen onder de jaartallen verwijzen naar de percentages geciteerde boeken en artikelen in de genoemde talen in verschillende jaargangen van Philosophical Transactions, het natuurwetenschappelijk tijdschrift van de Britse Royal Society dat al meer dan driehonderd jaar bestaat.

$\begin{array}{lrrrrrrrrrrr} & 1665 & 1700 & 1750 & 1800 & 1850 & 1870 & 1890 & 1910 & 1930 & 1950 & 1970 \\ \text { Engels } & 48 & 29 & 33 & 57 & 56 & 61 & 68 & 63 & 66 & 81 & 86 \\ \text { Frans } & 12 & 4 & 13 & 23 & 23 & 15 & 9 & 10 & 8 & 7 & 2 \\ \text { Duits } & 0 & 0 & 0 & 7 & 14 & 21 & 21 & 26 & 22 & 8 & 7 \\ \text { Latijn } & 35 & 60 & 47 & 10 & 7 & 2 & 1 & 0 & 0 & 0 & 0\end{array}$

Tabel 1 Taalgebruik van publicaties waarnaar verwezen wordt in artikelen in verschillende jaargangen van Philosophical Transactions tussen 1665 en 1970 (in procenten). (Naar Allen, Qin en Lancaster, 1994: 300)

De tabel illustreert (in ieder geval voor de natuurwetenschappen) dat het Latijn als een dominante wetenschappelijke taal tot het einde van de achttiende eeuw standhield; dat het Frans aanvankelijk sterk vertegenwoordigd was, maar in de tweede helft van de negentiende eeuw aan invloed verloor; dat de negentiende-eeuwse opmars van het Duits in de twee wereldoorlogen werd gesmoord; en dat het Engels langzaam maar zeker het (bijna-)alleenrecht verwierf, uiteraard mede onder invloed van de groeiende invloed van Amerika op het onderzoek.

Het dalende belang van het Latijn illustreert het afnemende belang van de klassieke teksten. In de humanistische vakgebieden, de geschiedenis en de taal- en letterkunde, vond in de achttiende en negentiende eeuw een heroriëntatie plaats. Na het gezamenlijk succes gingen ze hoe langer 


\section{Simon Stevin (1548-1620)}

Stevin, geboren in Brugge maar vooral werkzaam in de Noordelijke Nederlanden, begon zijn loopbaan als boekhouder. Hij is wel aan de Leidse universiteit ingeschreven geweest (als studiosus litterarum, letterenstudent). Maar hij ontwikkelde zichzelf grotendeels zelfstandig tot wiskundige en ingenieur met veel gevoel voor de praktische toepassingsmogelijkheden van zijn geleerdheid. Hij introduceerde het rekenen met decimale breuken in het onderwijs.

Stevin is het prototype van de volmaakte technicus, zegt zijn biograaf Dijksterhuis. Hij diende Prins Maurits als leermeester, als ingenieur in diens leger en als hoofd van zijn financiële administratie. Maar hij had ook belangstelling voor taal. Hij leverde praktisch en theoretisch een belangrijke bijdrage aan de opwaardering van het Nederlands als wetenschappelijke taal. Hij publiceerde voornamelijk in het Nederlands. In al zijn werk deed hij zijn best om voor allerlei begrippen geen leenwoorden te gebruiken, maar gewone Nederlandse woorden te hanteren. Waar die ontbraken, vormde hij nieuwe. Aan hem danken we woorden als evenredig, raaklijn, omtrek, toppunten vele andere.

hoe meer hun eigen weg. De studie van de contemporaine en op het eigen land gerichte geschiedenis gaat een grotere aandacht vragen, en daar hebben de historici de taalkundigen niet direct voor nodig. In de taalkunde ontwikkelde men eigen nieuwe vraagstellingen, met name betreffende de oorsprong en de verwantschap van de talen, waarin het Latijn niet een bijzondere positie meer heeft. Langzamerhand ontstond er ook een wetenschappelijke belangstelling voor de letterkunde van de eigen taal.

Ook de oudere teksten in het Nederlands, het Duits, het Engels, het Frans etc. bleken zich te lenen voor tekstkritiek, interpretatie en historische inkadering. Daaruit ontstonden rond 1900 zelfstandige studierichtingen, die van de 'moderne talen', met een overigens overwegende belangstelling voor oudere teksten. De bestudering van de talen en de literaire producten van de eigen tijd krijgt pas in de twintigste eeuw vaste grond onder de voeten. Het doel van de nieuwe vakbeoefening blijft dat van het humanisme: het levend houden van het 'historisch erfgoed', het doorgeven van het waardevolle uit het verleden aan de huidige en volgende generaties. Uit de mond van hoogleraar klassieke talen Francken aan het eind van de negentiende eeuw klinkt het zo:

Waarom [bestudeeren] wij [...] taal en literatuur, in zonderheid oude? Om ons verstand te scherpen, ons zedelijk gevoel te versterken, onzen smaak te verfijnen en te ontwikkelen; wilt gij het met één 
woord hooren, om in de waren zin humane menschen te worden. (geciteerd bij Laan 1997: 61)

\section{1 .3}

de opkomst van de

natuurweten-

schappen, de

wiskunde en de

empirische methode

Twee ontwikkelingen: de opkomst van de natuurwetenschappen

De tweede ontwikkeling die de aandacht vraagt, is de opkomst van de natuurwetenschappen, een ontwikkeling die voor die van alle wetenschappen van buitengewoon grote betekenis is geweest. Ook deze ontwikkeling leunt op de tekstkennis van de humanisten, maar zal er op den duur toch voor zorgen dat de humanistische kennis naar een tweede plan wordt verschoven. Ook is in de ontwikkeling de bijdrage van de genoemde 'technici', en de opkomst van de landstaal onmiskenbaar. (Van Berkel 1985; Grafton 1996) Kenmerkend is het dat boeken waaruit mensen leerden rekenen, vanaf de vroegste tijd allemaal in de landstaal zijn geschreven. (Kool 1999)

De natuurwetenschappelijke revolutie voltrok zich over een breed front van vakken, maar spreekt het meest tot de verbeelding door de ontdekkingen op het gebied van de astronomie. Men denke aan het werk van Copernicus, Keppler en Galileo Galilei. Zij ontdekten dat de aarde niet het centrum van het heelal is en de mens dus niet het middelpunt van de schepping, en ze onderbouwden deze visie met een sterk wiskundig georiënteerde bewijsvoering. Deze omwenteling vond zijn bekroning in het werk van Newton (1642-1727) die er in slaagde ontwikkelingen in de wiskunde, de astronomie en de mechanica met elkaar te integreren in een synthese, die een paar eeuwen onaantastbaar bleef.

De omwenteling wordt ook belichaamd in het werk van de Engelsman Francis Bacon (1561-1626), die ijverde voor een zuivering van de wijzen waarop mensen tot de waarheid konden komen. Hij wantrouwde de taal als voertuig van de waarheid, en meende dat uitsluitend door de menselijke ervaring, dat wil zeggen door waarneming, ware kennis kon worden verworven. Dit speelde in op de zich ontwikkelende praktijk van de wetenschappen.

Eigen waarneming, eventueel van een experimenteel gecreëerde of gemanipuleerde werkelijkheid, werd langzamerhand superieur aan de autoriteit van de klassieke teksten. Die nieuwe houding werd gestimuleerd door de uitvinding van wetenschappelijke instrumenten, zoals microscopen, verrekijkers en klokken. Die houding kwam ook tot uiting in een hele reeks van verschijnselen die in de middeleeuwse wetenschap nog zeldzaam waren en vanaf de zestiende eeuw frequenter werden:

- het verzamelen en documenteren van 'naturalia': gesteenten, planten, opgezette dieren en dierskeletten; 
het succes van de nieuwe wetenschappelijke methode

de natuurwetenschappen als ideale wetenschap
- het verzamelen en documenteren van 'artificialia': alle mogelijke bijzondere dingen die mensenhanden gemaakt hadden: objecten uit andere beschavingen, natuurwetenschappelijke instrumenten etc.;

- het inrichten van anatomische 'theaters' waar in anatomische lessen lijken werden ontleed. De sectie van een lijk trok steeds veel publiek. (Rupp 1991) Zoals bekend werden de anatomische lessen door beroemde schilders zoals Rembrandt gekonterfeit;

- de aanleg van botanische tuinen, voor meer dan medicinale doelen alleen.

De rol die het wetenschappelijke humanisme in deze ontwikkeling speelt, moet zeker in de zestiende en zeventiende eeuw nog aanzienlijk zijn geweest. Nog steeds leverden de klassieke teksten voorbeelden; en belangrijke natuurwetenschappelijke problemen waren vaak al in de klassieke teksten geformuleerd. Maar de rol die de uit de oudheid overgeleverde kennis speelt, neemt langzamerhand af. Er komen nog maar weinig nieuwe teksten boven water, en de nieuwe natuurbeschouwing deed afbreuk aan het - eertijds zo onaantastbaar lijkende - gezag van de Aristotelische natuurfilosofie.

Hoewel alle wetenschappen nieuwe ontdekkingen deden door de autoriteit van de tekst aan te vallen en in te ruilen voor de zelfstandige waarneming, boekten vooral de natuurwetenschappen vanaf de zeventiende eeuw de meest indrukwekkende resultaten. Zij deden aan de ene kant de meest gedurfde voorspellingen die nog uitkwamen ook. Aan de andere kant bleken hun inzichten in toenemende mate praktisch bruikbaar. Ze voorspelden steeds preciezer het bestaan en de beweging van planeten of de aard van chemische elementen en hun verbindingen. Ze ontdekten natuurkrachten en brachten die onder menselijke controle. Ze slaagden er in tot dan toe niet bestaande stoffen met nieuwe eigenschappen te maken en ze ontdekten nieuwe productieprocessen die efficiënter werken mogelijk maakten of gevaren konden voorkomen. Van lieverlee produceerden ze dus kennis en inzichten die niet alleen de nieuwsgierigheid bevredigden, maar ook nog toepasbaar bleken. Ze creëerden mogelijkheden voor het ontstaan van de wetenschap en de techniek in de vorm waarvan we de effecten iedere dag om ons heen kunnen zien.

De natuurwetenschappen gingen op den duur het beeld van de ideale wetenschap bepalen. Zij waren in staat te laten zien dat alle materie van plaats en aard verandert in overeenstemming met wetten van de natuur. Deze natuurwetten bleken in wiskundige formules te kunnen worden beschreven. De wetten bleken getoetst te kunnen worden door de werkelijkheid onder nauwkeurig gecontroleerde omstandigheden en met behulp van ingenieuze instrumenten te manipuleren. De experimentele werkwijze van de natuurwetenschappen, maar ook hun succesrijke status werd maatgevend voor de andere wetenschappen. 
reductionisme

\section{1 .4}

alfa's en bèta's twee culturen?

organisatorisch is er soms nog een eenheid...
Voor sommigen gaat de superioriteit van de natuur nog verder. Zij menen dat de wetenschappen alle aspecten van de werkelijkheid die de moeite van het bestuderen waard zijn, tot natuurkundige verschijnselen zouden moeten kunnen herleiden. Historische gebeurtenissen, menselijke communicatie, creativiteit, emoties: ze zouden alleen op wetenschappelijke wijze te kennen zijn als we ze reduceren tot fysische processen. Deze zienswijze wordt reductionisme genoemd.

\section{Twee culturen}

De beide ontwikkelingen die we kort hebben beschreven - enerzijds de opkomst van de landstaal als concurrent van het Latijn, en de heroriëntatie van geschiedenis en taal- en letterkunde op nieuwe onderwerpen die daar mee gepaard gaat, en anderzijds de ontwikkeling van de wiskundig en experimenteel georiënteerde natuurwetenschappen -,geven aan de humaniora en de natuurwetenschappen een andere positie in het wetenschappelijk bedrijf. Sommigen menen zelfs dat er tegenwoordig van een diepe, onoverbrugbare cultuurkloof moet worden gesproken. Wanneer die toestand zou zijn ingetreden, is overigens niet zo duidelijk. (Frijhoff 1988) We wijzen kort op een paar relevante facetten van deze ontwikkeling.

In de zeventiende-eeuwse universiteiten schaarden de trivium-vakken zich net als de natuurwetenschappen nog altijd organisatorisch onder de filosofie. In een zeventiende-eeuwse beschrijving van het Auditorium Philosophicum, de filosofische collegezaal, van de Leidse universiteit lezen we:

Alhier werden [...] ghedaen de Lessen in Philosophia: Te weten in Logica, Physicis [natuurfilosofie], Ethicis, Polyticis [staatsinrichting], Poesis, Rethoricis, als mede in Historiis, Lingua Graeca \& Arabica, etc. (Orlers 1641)

Dezelfde bron vermeldt dat de Leidse Universiteitsbibliotheek verschillende boekenkasten had voor theologie, filologie, filosofie, poëzie (letterkunde), wiskunde, rechten, medicijnen, geschiedenis en handschriften. Ook dit wijst niet op een duidelijke scheiding in twee culturen.

Ook de Encyclopédie ou dictionnaire raisonnée des sciences, des arts et des métiers, die imposante achttiende-eeuwse onderneming van de Fransen Diderot en d'Alembert (1751-1772) om alle 'weten' in één veeldelig boekwerk bijeen te brengen, kent zo'n scheiding tussen humaniora en natuurwetenschappen nog niet.

... tot rond $1800 \quad$ In de organisatievorm van de universiteiten waren er nog altijd vier 
academies

KNAW

differentiatie van de wetenschappen faculteiten, al kan men soms ook (zoals Goethes Faust) in de filosofie doctor worden. Dit blijft zo tot rond 180o. In die periode verandert er veel. Dan worden - vooral naar Duits voorbeeld - de universiteiten ook instellingen voor wetenschappelijk onderzoek. Dan worden 'letteren' en 'natuurwetenschappen' gescheiden faculteiten, en ontstaat de mogelijkheid er de doctorsgraad in te behalen. Het onderscheid tussen de oude 'hogere' faculteiten en de 'lagere' artes- of filosofische faculteit wordt opgeheven.

Inhoudelijke en methodologische verschillen tussen alfa's en bèta's laten zich her en der natuurlijk ook al wel vroeger in de organisatie van de vakgebieden gelden. Dat is bijvoorbeeld soms het geval met de academies. Wat zijn academies?

In de vijftiende eeuw ontstaan er eerst in Italië, maar later ook elders in Europa gezelschappen geleerden en kunstenaars, die zich soms, in navolging van het gezelschap filosofen rond Plato (428-348 v. Chr), 'academie' noemen. Ze werden centra van correspondentie en discussie. Zonder een directe onderwijstaak en minder strak georganiseerd dan de universiteiten, speelden sommige van deze academies en genootschappen een grote rol bij de ontwikkeling van de wetenschappen. Sommige academies ontwikkelden zich tot groepen met een groot internationaal, wetenschappelijk gezag. Groter soms dan dat van de universiteiten.

Bij de academies zien we soms een scheiding van alfa's en bèta's. Er werden bijvoorbeeld in Frankrijk onder andere een academie van taalen letterkundigen opgericht, de Académie Française (1635), en een voor de natuurwetenschappen, de Académie des sciences (1666). Ook de Engelse Royal Society, daterend van 1660, bestrijkt uitsluitend de natuurwetenschappen.

Een dergelijk wetenschappelijk genootschap op nationale schaal, kwam in Nederland pas tot stand in de Napoleontische tijd. Net als overal elders in Europa was er toen de duidelijke behoefte het terrein van de zo geëxpandeerde wetenschappen ook organisatorisch langs andere lijnen te verkavelen dan vanaf de Middeleeuwen gebruikelijk was. De Koninklijke Nederlandse Academie van Wetenschappen, opgericht in 1808, kent sinds 1855 twee afdelingen waarin alle wetenschappen zijn ondergebracht, een afdeling voor de 'natuurwetenschappen' en een voor de taal-, letter- en geschiedkundige en wijsgerige wetenschappen. Daarmee was een parallellie gecreëerd met de al genoemde opdeling van de oude artesof filosofische faculteit in twee nieuwe: die van de wis- en natuurkunde en die van de letteren en wijsbegeerte.

Inhoudelijk gezien was er onder de vrije wetenschapsbeoefenaren al veel langer sprake van veel meer verschillende hoe langer hoe duidelijker afgebakende vakgebieden en specialismen met eigen denkwijzen, terminologieën, tijdschriften, verenigingen etc. Eind achttiende, begin 
de wetenschappen zijn één

hiërarchie van wetenschappen

een speciale positie voor de geesteswetenschappen? negentiende eeuw vormen zich de sociale wetenschappen als afsplitsingen van zowel de natuurwetenschappen als de geesteswetenschappen. Binnen de sociale wetenschappen verwerft de economie zich een eigen plaats.

De verschillen tussen de wetenschappen worden in de eerste plaats bepaald door de werkelijkheid die men bestudeert, en de benaderingswijze, het perspectief dat men kiest. Daardoor zijn de grenzen tussen de wetenschappen niet precies bepaald. Voor de meeste onderzoekers zijn die grenzen ook niet erg interessant. Het gaat er om of de opbrengst van het onderzoek interessant is.

Hebben de wetenschappen nog iets gemeenschappelijks behouden? Nog heel lang was het tamelijk onomstreden, dat de wetenschappen weliswaar allemaal verschillende delen van de werkelijkheid bestudeerden, maar dat allemaal op dezelfde wijze deden. Er was - zo meende men slechts één wetenschappelijke methode. Experimenteren, classificeren en mathematiseren waren daarin kenmerkende activiteiten. Dit is een van de grondideeën van het zgn. positivisme. De wetenschappen zijn één, omdat ze op dezelfde manier naar de waarheid streven. Sommige wetenschappen waren verder gevorderd dan andere, maar die andere zouden op den duur ook de ware weg moeten vinden om het predikaat 'echte wetenschap' te verdienen.

Het idee ontstond dat de wetenschappen in een hiërarchie zijn geordend. Wat het verst op de weg naar de waarheid is gevorderd, staat bovenaan in de hiërarchie. Daar vinden we de wetenschappen die de 'dode natuur' bestuderen: de natuurkunde, de scheikunde, de sterrenkunde, de geologie; dan de wetenschappen van de 'levende natuur': de biologie, de medicijnen, de biochemie etc.; en dan volgen de geesteswetenschappen en de sociale of gedragswetenschappen.

Natuurlijk was het niet aanstonds duidelijk hoe de ideale wetenschappelijke methode eruitzag. Er waren onmiskenbaar wetenschappelijke successen, maar er waren uit het succes van de meest gevorderde wetenschappen niet zomaar recepten af te leiden die de andere slechts behoefden te volgen om hogerop te geraken. Over de juiste weg werd wel veel gediscussieerd. Vooral onder filosofen.

Tegen de idee dat de wetenschappen één zijn en dat er maar één wetenschappelijke methode bestaat, keren zich aan het eind van de negentiende eeuw een aantal Duitse filosofen-historici, waaronder Dilthey en Droysen. Zij claimen voor de Geisteswissenschaften een eigen methode, omdat het object van die wetenschappen anders is dan dat van de natuurwetenschappen.

Is dat zo? Is er zoiets als het eigene van de geesteswetenschappen? Rond 1900 vinden we verschillende pogingen om de eigenheid van de geesteswetenschappen nader te bepalen. 
zijn de geesteswetenschappen bij uitstek 'idiografisch'?

de geesteswetenschappen bij uitstek 'menswetenschappen'?

de geesteswetenschappen bij uitstek de wetenschappen van 'waardegeladen' objecten?

de letteren gedefinieerd door een cultuurvisie? houden de letteren zich bezig met'het hogere'?
Windelband probeerde de beide kennisgebieden te onderscheiden met behulp van het begrippenpaar nomothetisch (= 'wettenstellend') vs. idiografisch (= 'het eigene beschrijvend'). Waar de natuurwetenschappen tot doel hebben algemene wetten op te stellen (nomothetisch), daar stellen de geesteswetenschappen zich tot doel unieke verschijnselen te beschrijven (idiografisch). En inderdaad: sommige alfavakken onderscheiden zich hierin van andere wetenschappen dat ze zich bezighouden met unieke door mensen gemaakte objecten, unieke vormen van menselijk handelen of unieke gebeurtenissen waar mensen bij betrokken zijn. Niet een willekeurig stuk geverfd hout waarvan er dertien in een dozijn gaan, maar het unieke beschilderde of gebeeldhouwde paneel, niet aardbevingen als weliswaar unieke, maar toch door algemeen werkende natuurkrachten veroorzaakte natuurverschijnselen, maar de steeds weer andere lotgevallen van de mensen die er door getroffen werden.

Belangstelling voor het unieke en het door menselijke betrokkenheid bepaalde deel van de werkelijkheid bepalen inderdaad een deel van het karakter van de kunstwetenschappen en de geschiedbeoefening. Maar de belangstelling voor het unieke karakteriseert de geesteswetenschappen maar gedeeltelijk. Historici hebben soms zeker ook belangstelling voor collectieve (niet-unieke) verschijnselen. En de taalkunde, ook een alfadiscipline, bestudeert in de eerste plaats het algemene psychische vermogen tot taal en niet het unieke gebruik dat er op een zeker moment door een individu van wordt gemaakt.

Ook zijn de alfawetenschappen niet exclusief de wetenschappen omtrent de mens. Er zijn immers menswetenschappen, die geen alfavakken zijn: psychologie en sociologie, economie en medicijnen zijn duidelijke voorbeelden.

Er is betoogd (door Rickert, ook rond 190o) dat de objecten van de geesteswetenschappen, in tegenstelling tot die van de natuurwetenschappen, waardegeladen zijn. Zo'n opinie is ook recent nog met overtuigingskracht over het voetlicht gebracht door Nussbaum (1997). Belangrijk is het inzicht dat het waardegeladen karakter van het object van onderzoek niet uit de lucht komt vallen. Het hangt samen met een visie op de cultuur.

Door de socioloog Goudsblom (1990) is de opvatting verdedigd dat de alfawetenschappen zich hierin onderscheiden van de andere menswetenschappen dat zij die dingen van de humane werkelijkheid als hun objecten beschouwen die vanuit een bepaalde visie op het menselijk bestaan en de cultuur van een bijzondere waarde zijn. Ze laten de 'vulgaire' aspecten, de 'lagere' functies (het menselijk lichaam, gezondheid en ziekten, driftleven, emoties, groepsgedrag, geld etc.) - hoe waardevol die ook zijn - over aan de andere menswetenschappen. Dit is in de lijn van hetgeen in de jaren zestig door een Amerikaanse presidentiële Commission on the Humanities werd gezegd: 
consequenties van deze begripsbepaling 'centrale' en 'perifere' onderzoeksgebieden

rechtvaardigt dit een eigen methode?
The humanities are the study of that which is most human. Throughout man's conscious past they have played an essential role in forming, preserving, and transforming the social, moral, and aesthetic values of every man in every age. (geciteerd in Bingham 1966: 79)

Zo gezien ligt aan de alfavakken een zeker elitair cultuurbegrip ten grondslag. Volgens deze zienswijze vertonen de letteren nog steeds dezelfde speciale waardegeladen visie op het menselijk bestaan en de cultuur als het Renaissance-humanisme.

Een door de Nederlandse overheid ingestelde commissie die zich over de toekomst van de alfavakken aan de universiteiten moest uitspreken, oordeelde recent: 'De geesteswetenschappen behoren een afscherming te vormen tegen de waan van de dag.' [...] 'Meer dan veel beroepen, en zelfs meer dan veel andere wetenschappen, bevatten de geesteswetenschappen een element van roeping.' Geld, status en invloed, daar moet men boven staan; die behoeft men van de beoefening van deze vakken niet te verwachten.

[...] de beoefenaars van de geesteswetenschappen zullen moeten accepteren dat zij in hun omgeving status, invloed en inkomen genieten die niet in overeenstemming zijn met het belang van de opdracht die zij door de gemeenschap aan zich zien toevertrouwd. (Commissie Toekomst van de geesteswetenschappen 1995: 21)

De bedoelde visie hecht een bijzondere waarde aan het individuele, aan creatieve vermogens, aan geschiedenis en 'historisch besef', aan taal als expressiemiddel van de geest, aan de 'hogere' cultuuruitingen zoals de kunsten. Onderwerpen die niet onmiddellijk in dit cultuurbegrip passen, zoals strips, popmuziek, massacultuur, vrouwengeschiedenis, geschiedenis van de techniek, volkskunde, dialectkunde, cultuurbeleid, of de toepassing van de verworven kennis; die onderwerpen zijn in de alfawetenschappen niet taboe, maar hebben er geen centrale plaats. Ze lijken in de alfadisciplines steeds op een aparte manier als onderzoeksobjecten verdedigd te moeten worden, of op een aparte manier bescherming te moeten krijgen.

De grote vraag is natuurlijk of dit een eigen methode rechtvaardigt. Rechtvaardigt dit de claim dat de geesteswetenschappen hun onderzoeksobjecten met een methode dienen te benaderen die principieel verschilt van de methode die in alle andere vakgebieden wordt gehanteerd? Aan dit boek ligt de overtuiging ten grondslag dat dit niet het geval is. Argumenten daarvoor worden in de volgende hoofdstukken gepresenteerd. 


\section{'Cultural studies'}

Onder het label 'cultural studies' is de laatste twee decennia van de twintigste eeuw - vooral in de Verenigde Staten - een tak van vakbeoefening gegroeid die speciaal de positie van zich emanciperende groepen in de westerse samenleving tot onderwerp van studie maakt. Een opwaardering van de bijdragen die vrouwen, homo's en lesbo's, zwarten, hispano's en (andere) culturele minderheidsgroepen aan de cultuur hebben geleverd, is nadrukkelijk de bedoeling. 'Cultural studies' onderstrepen het multiculturele karakter van de moderne samenleving. Er is veel aandacht voor uitingen van massacultuur. Er is ook sprake van een herwaardering van de ethische aspecten van literair werk en andere cultuuruitingen.

De methoden van onderzoek verschillen in hoofdlijnen niet van de in de geesteswetenschappen gebruikelijke. Deconstructie wordt er vaak toegepast.

Verschillende Amerikaanse universiteiten en colleges hebben deze onderwerpen in hun curricula en onderzoeksprogramma's geïncorporeerd.

Bron: Martha Nussbaum, Cultivating humanity

1.2

het ontstaan van de wetenschapsfilosofie

het materiaal van de wetenschapstheorie

\section{Wetenschapsfilosofie}

Aan het begin van de twintigste eeuw ontstond een nieuwe wetenschap, die zich bezig ging houden met 'de wetenschappen'. Een wetenschap van de wetenschap dus. Deze wetenschap wordt doorgaans wetenschapstheorie genoemd, soms ook wetenschapsfilosofie of wetenschapsleer. Tot de grondleggers van de wetenschapsfilosofie behoren de logisch-positivisten, een groep filosofen waarvan er een aantal verenigd waren in de Wiener Kreis. Tot de logisch-positivisten behoren onder anderen Rudolf Carnap (1891-1970) en Carl Hempel (1905-1997). Daarnaast is het werk van Karl Popper (1902-1994) baanbrekend voor de wetenschapsfilosofie geweest. Ook hij was Wener van geboorte, en generatiegenoot van de leden van de Wiener Kreis, maar hij koos een eigen benadering van de wetenschapsfilosofische problematiek.

De wetenschapstheorie bestudeert de redeneringen die wetenschappers tot hun conclusies hebben gebracht. Men beoordeelt er de logica van en de verborgen veronderstellingen. Daarnaast bestudeert de wetenschapstheorie ook de feitelijke werkwijze van wetenschappers, de manier waarop ze zich georganiseerd hebben en een maatschappelijke positie verwerven. De wetenschapstheorie is dus geïnteresseerd in vragen als: Hoe werken wetenschappers? Hoe redeneren ze? Wat beschouwen ze als 
goede wetenschap? Wat beschouwen ze als vooruitgang op hun vakgebied? Hoe rechtvaardigen zij hun standpunten als ze het met andere wetenschappers oneens zijn? Wat doen ze als ze iets anders vinden dan ze verwacht hadden? Het materiaal om deze vragen te beantwoorden haalt de wetenschapstheorie overal vandaan: autobiografische geschriften, vraaggesprekken met onderzoekers, beschrijvingen van succes en (in mindere mate) mislukking, overheidsstukken en beleidsstukken van tijdschriftuitgevers of organisatoren van wetenschappelijke congressen, voorstellen voor onderzoeksprojecten etc. Men kan zich dus wel voorstellen dat de wetenschapstheorie sterk verweven is met de geschiedenis van de wetenschappen en met de sociologie van de wetenschappen. De geschiedenis van de ideeën over wetenschap, wetenschappelijke kennis en hoe die kan worden verworven, is nu eenmaal verweven met de geschiedenis van de onderzoekers en de sociale structuren (universiteiten, bibliotheken, onderzoeksinstituten, academies etc.) waarvan zij deel uitmaakten.

Misschien omdat de resultaten van de natuurwetenschappen en de spin-off in de technologie het spectaculairst zijn, heeft de aandacht van de wetenschapstheorie zich vooral gericht op de natuurwetenschappen. De status die die wetenschappen zich verwierven gaf ook de meeste verplichtingen. Toepasbaarheid ging eisen stellen aan de 'zuivere wetenschap'. De toepassingen moesten betrouwbaar, efficiënt en effectief zijn. De wetenschap moest kunnen laten zien waarop de 'geclaimde' waarheid berustte, en diende zich tegen vermoedens van onbetrouwbaarheid en scepsis te kunnen verdedigen.

Naast de filosofie van de natuurwetenschappen en die van de sociale wetenschappen is de filosofie van de geschiedbeoefening een ontwikkelde tak van de wetenschapsfilosofie. De filosofieën van de andere geesteswetenschappen zijn veel minder tot ontwikkeling gekomen.

1.3

doel van dit boek

\section{Doel en uitgangspunten van dit boek}

Dit boek probeert enkele aspecten van een theorie van de wetenschappen te beschrijven aan de hand van de praktijk van de letterenvakken. De belangstelling gaat niet in de eerste plaats uit naar de verhouding van deze vakken tot de natuurwetenschappen. Niet de vraag 'hoe ze zich zouden moeten gedragen om in de hiërarchie der wetenschappen "hogerop" te geraken', staat centraal. We proberen ze te nemen zoals ze zijn. Ook gaan we er niet van uit dat de letterenvakken vanuit een wetenschapstheoretisch standpunt uniform kunnen worden beschreven. 
uitgangspunten

dubbele taak van de wetenschap

doel van het voortbrengen en het beheer van kennis

wetenschappelijke kennis en waarheidsaanspraken

de menselijke rede heeft zijn grenzen
We hanteren de volgende uitgangspunten. We nemen aan dat de eerste taak van alle wetenschappen is: kennis voort te brengen. De wetenschappen zijn er op gericht nieuwsgierigheid te bevredigen en intellectueel interessante problemen op te lossen. De tweede functie van alle wetenschappen is: kennis te beheren. Hoewel dit zeker in alle wetenschappen een rol speelt, is deze taak voor de geesteswetenschappen van bijzonder belang. In het navolgende zullen we onze aandacht vooral richten op factoren die een rol spelen bij de kennisproductie, maar in het laatste hoofdstukken zal ook blijken van welk vitaal belang de kennisbeheersfunctie van de alfavakken is, en hoe verweven die is met de kennisproductie.

Het voortbrengen en het beheren van kennis heeft tot doel de werkelijkheid beter te leren begrijpen. De werkelijkheid te begrijpen is ongetwijfeld een diepe menselijke behoefte. Mensen kunnen nu eenmaal moeilijk leven met verschijnselen die ze niet in relatie kunnen brengen met hetgeen ze al menen te weten.

Uit wetenschappelijk onderzoek vloeien vaak technische toepassingen voort, maar deze toepassingen zijn geen noodzakelijke voorwaarde om van 'wetenschap' te spreken. Kennis die ons de werkelijkheid beter doet begrijpen, kan ook andere vormen hebben dan die van natuurwetten die voorspellingen toelaten en de werkelijkheid daardoor beheersbaar maken. Verschijnselen kunnen in sommige gevallen ook verduidelijkt worden door samenhangende beschrijvingen of classificaties van gegevens.

Iemand die kennis presenteert, maakt er doorgaans aanspraak op dat de gepresenteerde kennis waar is. Maar als je aan wetenschappers vraagt of hun theorieën waar zijn, voelen ze zich in verlegenheid gebracht. Met het pistool op de borst zullen ze wellicht zoiets zeggen als 'Ja, althans... wat ik beweer, is dichter bij de waarheid dan wat anderen over dit onderwerp beweerd hebben. Het verklaart de bekende feiten het beste, het levert het meest coherente beeld. Maar onwankelbaar waar?? Tja!'

Het idee dat wetenschappelijke kennis waar is, staat ook op gespannen voet met het gevoel dat de wetenschap vooruitgaat. Als wetenschappelijke kennis geen ware kennis is, maar kennis die op een bepaald moment als waar wordt gepresenteerd, dan impliceert dit de mogelijkheid dat deze kennis in de toekomst onwaar zou kunnen blijken. De aanspraken van de wetenschap op waarheid kunnen niet verder gaan dan dit: wetenschappelijke kennis is de best mogelijke kennis op een bepaald moment, de kennis waar de best mogelijke rationele rechtvaardiging voor kan worden gegeven. Aan de mogelijkheden van onze menselijke rationaliteit zijn door de menselijke natuur grenzen gesteld. Ons verstand kan kwaliteitseisen voor wetenschappelijke kennis bedenken, waar datzelfde verstand onmogelijk aan kan voldoen. Dit idee van de door de menselijke natuur begrensde rationaliteit van de wetenschappen zal richtinggevend voor onze uiteenzettingen zijn. 
kennis is openbaar

samenvatting van uitgangspunten
Wetenschappelijke kennis is openbaar. Zolang een gedachte zich slechts ophoudt in het hoofd van een onderzoeker, is het voor de wetenschap geen kennis.

Wetenschappelijke kennis is nillens willens vastgelegd in taal: een geformaliseerde taal of een natuurlijke taal en alles wat een tussenvorm is. De consequentie van de talige vorm van wetenschappelijke kennis is in de moderne wetenschapstheorie een van de meest bediscussieerde thema's.

We denken dat deze uitgangspunten een raamwerk vormen voor het onderzoek van de meeste wetenschappers en ook voor hen die zich bezig houden met de geesteswetenschappen. We vatten ze nog eens samen:

- wetenschappelijk onderzoekers presenteren hun kennis als waar, maar zullen toegeven dat de gepresenteerde kennis in principe voor correctie en uitbreiding open is;

- ze zullen het idee onderschrijven dat door de menselijke natuur grenzen zijn gesteld aan de mogelijkheid de werkelijkheid te ontraadselen;

- de geproduceerde kennis heeft een openbaar karakter, en gebruikt de natuurlijke taal of geformaliseerde talen (de wiskunde, de logica etc.) als uitdrukkingsmiddel;

- de productie en het beheer van wetenschappelijke kennis dienen in de eerste plaats het begrijpen van de werkelijkheid, en pas in tweede instantie het manipuleren ervan.

vooruitblik

In het volgende hoofdstuk gaat het allereerst over de vraag hoe wetenschappelijke kennis van andere kennis kan worden onderscheiden 


\section{$2 \quad$ Soorten kennis}

demarcatiecriteria Wetenschapsfilosofen houden zich onder meer bezig met de vraag wat de wetenschap van andere vormen van cultuur onderscheidt. Niet alle vormen van kennis worden door wetenschappers als wetenschappelijke kennis erkend. De wetenschapsfilosofie onderzoekt de argumenten die gebruikt worden om het onderscheid te markeren. De gehanteerde criteria worden demarcatiecriteria genoemd.

normatief weten-

In de eerste helft van deze eeuw was de wetenschapsfilosofie er op schapsbegrip

wat wetenschappen

zijn, is een maatschappelijk gegeven

vooruitblik gespitst om regels te geven voor wat goede of echte wetenschap van slechte of quasi-wetenschap onderscheidde. De wetenschapsfilosofie was normatief. Zo getroostte de wetenschapsfilosoof Karl Popper zich veel moeite om, uitgaand van bepaalde beginselen, aan te tonen dat het buitengewoon invloedrijke werk van de econoom Karl Marx of dat van de medicus Sigmund Freud niet tot de wetenschap gerekend kon worden. En de wetenschapsfilosoof Hempel heeft geprobeerd te bewijzen dat de historici niet aan de vereisten van wetenschappelijk onderzoek voldoen. Aan het eind van de twintigste eeuw is grosso modo de houding gegroeid te accepteren dat de wetenschappen zijn zoals ze zijn. Dat ze maatschappelijke verschijnselen zijn met hun eigen regels, ordening en dynamiek.

Dat ontslaat de wetenschappen niet van de verplichting te laten zien in welke opzichten wetenschappelijke kennis van andere soorten kennis verschilt. Daar beginnen we onze uiteenzettingen mee. Zo bakenen we ook het terrein af voor de volgende hoofdstukken.

We onderscheiden in de volgende paragrafen de volgende soorten kennis: godsdienstige kennis, alledaagse kennis, pseudo-wetenschappelijke kennis en journalistieke of essayistische kennis. Het gaat steeds om (voor bepaalde mensen) gerechtvaardigde overtuigingen, waarvoor in de omgangstaal het woord 'kennis' wordt gebruikt. De principiële vraag of men in al deze gevallen wel terecht van 'kennis' kan spreken, laten we hier terzijde. 
religieuze kennis is 'geopenbaard'

voor gelovigen is religieuze kennis waar

religieuze kennis groeit niet religieuze kennis is dogmatisch, niet open voor kritiek
Voor Thomas van Aquino, de middeleeuwse systematiseerder van theologische kennis, was de filosofie de dienstmaagd van de theologie. De kennis van de werkelijkheid stond in dienst van de veel machtigere en hogere kennis omtrent God en de godsdienst. We duiden deze laatste kennissoort hier aan met de term godsdienstige of religieuze kennis. Voor gelovigen is de kennis omtrent God en godsdienst gebaseerd op een openbaring in enigerlei vorm. Dat wil zeggen dat de kennis door daartoe 'uitverkorenen' aan de mensen kenbaar is gemaakt en in vaak heilig genoemde boeken opgeschreven. De Bijbel en de Koran zijn voorbeelden van zulke boeken.

Omdat de uitverkorenen deze kennis rechtstreeks van God zouden hebben ontvangen, kan er niet aan getwijfeld worden. Religieuze kennis is voor de gelovige waar, en boven elke twijfel verheven.

Een belangrijk kenmerk van religieuze kennis is dat deze niet uitgebreid wordt. De nieuwe catechismus van de katholieke Kerk, een systematische samenvatting van de officiële religieuze kennis van die kerk, beschrijft dat als volgt:

Er zal geen andere openbaring meer zijn. [...] In de loop der eeuwen zijn er zgn. 'bijzondere of privé' openbaringen geweest, waarvan er sommige door het gezag van de kerk erkend zijn. Zij behoren echter niet tot de geloofsschat. Hun rol is niet de definitieve openbaring van Christus te 'verbeteren' of 'aan te vullen', maar te helpen deze voller te beleven in een bepaald tijdperk van de geschiedenis. (Katechismus 1995:31)

De geopenbaarde kennis geldt dus als de laatste waarheid. Hiervoor worden allerlei rechtvaardigingen gegeven, waarvan een van de belangrijkste is dat God zelf onveranderlijk is en dus niet terug kan komen op een door hem geopenbaarde waarheid. Gelovigen koesteren de authentieke vorm ervan, juist omdat de kennis uit een bron komt die zij hoog achten. De catechismus van de katholieke Kerk bijvoorbeeld bestaat bijna geheel uit niet verder becommentarieerde citaten uit andere teksten.

Hier vinden we een belangrijk verschil met wetenschappelijke kennis. Deze laatste immers groeit alsmaar: er is geen laatste wetenschappelijke waarheid.

Een ander verschil betreft het feit dat gelovigen religieuze kennis niet ter discussie stellen. Religieuze kennis is dogmatisch. De bron van die kennis, God, maakt dat de kennis zelf onaantastbaar is. Kennis die als waarheid is geopenbaard, kan niet door mensen worden weerlegd, of verbeterd. Hij moet als waar worden aanvaard.

Interpretatie van de openbaring is wel mogelijk. Het katholicisme kent aan de Paus, het hoofd van de rooms-katholieke Kerk, de eigenschap 
strijdvragen van geloof en wetenschap

de religieuze kennis is in de verdediging gedrongen toe dat hij met onfeilbare zekerheid kan beslissen welke interpretaties 'waar' zijn.

Het is daarentegen een wezenlijk kenmerk van wetenschappelijke kennis dat die aan kritiek blootgesteld moet kunnen worden: wetenschappelijke kennis hoort open te zijn voor kritiek. De meeste wetenschappers beschouwen zichzelf als feilbaar.

De twee laatstgenoemde aspecten waarin wetenschap van religieuze kennis verschilt, staan niet los van elkaar. Het groeien van kennis en het verbeteren van bestaande kennis zijn twee zijden van één medaille. Het definitieve en het dogmatische zijn twee zijden van een andere.

De emancipatie van de wetenschappelijke kennis uit de overheersing door de religie heeft in de westerse cultuur enkele eeuwen in beslag genomen. Ze heeft zich voltrokken in de zeventiende tot en met de negentiende eeuw; en ging met veel conflicten gepaard. Uiteraard spitsten die zich toe op die dingen waar de inzichten van wetenschap en religie uiteenliepen.

Aanvankelijk was de wetenschap, de rationele kennis, in de minderheid, en moesten nieuwe wetenschappelijke inzichten minutieus worden verdedigd, ook voor kerkelijke rechtbanken. Het bekendste voorbeeld is het genoemde verzet tegen het werk van Galileo Galilei. Langzamerhand echter zijn, zeker in de westerse wereld, de kerken - de instituties die de religieuze kennis vertegenwoordigen - in de verdediging gedrongen.

Kenmerkend voor die verdedigende houding is het zgn. creationisme, een christelijk geïnspireerde oppositie tegen het Darwinisme. Het cre-

\section{Klassieke geschilpunten tussen geloof en wetenschap}

- de mogelijkheid het bestaan van God te bewijzen;

- het ontstaan van de wereld, en van de dode en levende natuur;

- de tegenspraak tussen bepaalde bijbelpassages en wetenschappelijke waarnemingen; beweegt de aarde om een stilstaande zon, of is de aarde het stilstaande middelpunt van het heelal: de kwestie waar Galileo Galilei in het begin van de zeventiende eeuw op werd aangevallen;

- het realiteitsgehalte van wonderen, dat wil zeggen van gebeurtenissen die strijdig zijn met hetgeen op basis van de fysische en organische werkelijkheid verwacht mag worden (een opstanding uit de dood; het tot stilstand komen van de zon etc.);

- de historiciteit van in de Bijbel beschreven gebeurtenissen zoals de zondvloed en van religieuze persoonlijkheden zoals Jezus van Nazareth. Heeft Jezus echt bestaan? Is er zoiets als een zondvloed geweest? 
moderne vorm van de tegenstelling tussen geloof en wetenschap

emancipatie voltooid

mythologische kennis

2.2

alledaagse kennis ationisme is een christelijke theorie over het ontstaan van de wereld en van de soorten levende wezens. Het verwerpt de evolutietheorie en is een poging om de resultaten van het natuurwetenschappelijk onderzoek over het ontstaan van de wereld en van de soorten een interpretatie te geven die ze verenigbaar maakt met het bijbelverhaal, dat vertelt dat de wereld in zeven dagen is geschapen. Volgens creationisten zou God de wereld met fossielen en al hebben geschapen. Dit creationisme heeft in Nederland zoveel maatschappelijk gewicht dat de Nederlandse regering recent besloot de evolutietheorie niet langer te beschouwen als een onderdeel van het centraal schriftelijk eindexamen biologie. Een krachtige tegenbeweging vanuit de wetenschappen moest er aan te pas komen om dit besluit weer ongedaan te maken.

Tegenwoordig wordt vanuit veel kerken niet zozeer de opvatting verkondigd dat de wetenschappen onware uitspraken doen en ongelijk hebben, als wel dat de wetenschappen aan de mensen het perspectief op een mogelijke zin van het leven hebben ontnomen door afbreuk te doen aan het religieuze bewustzijn. Niet de waarheid van wetenschappelijke kennis staat meer ter discussie, maar de gevolgen ervan voor de samenleving. Voor een beschouwing over deze problematiek zie Van den Beukel (1990).

Aan het einde van de twintigste eeuw blijkt het emancipatieproces van de wetenschappen in de westerse cultuur voltooid. De aanspraken van de wetenschappen zijn door de grote religies de facto erkend.

Veel van wat hier gezegd is over de religieuze kennis geldt ook voor mythologische kennis. Daarbij denken we speciaal aan de kenniselementen uit de oude klassieke mythen van de Grieken en Romeinen, uit de Germaanse of Keltische mythen of uit moderne mythen als die van het fascisme en het duizendjarig rijk (Von der Dunk 1974). In tegenstelling tot religieuze kennis is mythologische kennis voor de gelovigen vaak van onduidelijke oorsprong. Maar ook hier geldt dat de kennis niet groeit en niet open is voor kritiek.

\section{Wetenschappelijke kennis vs. alledaagse kennis}

Men hoeft geen wetenschapper te zijn om te beschikken over een grote verzameling kennis. Men weet in het algemeen wie zijn ouders zijn, of waren, waar men woont, op welk adres men werkt, waar de dichtstbijzijnde Albert Heijn gevestigd is, wat de hoofdstad van Frankrijk is, waar men vorig jaar met vakantie is geweest etc. Dit soort kenniselementen noemen we alledaagse kennis. Het zal duidelijk zijn dat alledaagse kennis verschilt van wetenschappelijke kennis, maar het verschil is niet gemakkelijk aan te wijzen. 
twee soorten trivialiteiten: weetjes...

... en common sense

alledaagse kennis en wetenschappelijke kennis

wetenschap stelt belang in triviale feiten

wetenschap wil meer dan trivialiteiten
Alledaagse kennis bestaat voor een deel uit trivialiteiten. Trivialiteiten zijn er in twee soorten. Soms gaat het bij alledaagse kennis om dingen die voor het leven van een individu buitengewoon belangrijk zijn, maar waarvan het belang ook tot het individu beperkt is. Ook kan het gaan om zaken die weliswaar algemeen bekend zijn, maar waarvan niet inzichtelijk is, welk belang het heeft die dingen te weten. Allerlei quiz-kennis is van deze aard. Je lijkt er weinig mee op te schieten of je weet wie bij de Olympische Spelen in 1960 kampioen verspringen werd of wanneer de planeet Uranus werd ontdekt.

Sommige alledaagse kennis betreft regelmatigheden: 'kerstbomen zijn te koop in de maand voorafgaand aan Kerstmis'; 'zout is goedkoper dan suiker'; 'jaloezie is nu eenmaal een moeilijk te beteugelen passie'. Common sense-uitspraken worden ze genoemd. Ze vormen de inhoud van ons gezond verstand. Common sense-uitspraken zijn herkenbaar aan de aanwezigheid van de woorden 'nu eenmaal'; of de mogelijkheid deze woorden zonder veel betekenisverandering aan de zin toe te voegen. Hun waarheid staat doorgaans niet ter discussie.

Het is zo op het eerste gezicht duidelijk dat het onderscheid tussen alledaagse en wetenschappelijke kennis, voorzover het om weetjes gaat, niet gelegen kan zijn in de onwaarheid of onbetrouwbaarheid van de eerste soort kennis en de waarheid of betrouwbaarheid van de laatstgenoemde. Een sterk punt van triviale kennis is namelijk dat er in veel gevallen zo weinig twijfel over bestaat. Weetjes zijn vaak waar. Zeker, er worden filosofische standpunten ingenomen die ook die zekerheid ondergraven, maar er lijkt op dit punt toch geen duidelijk verschil tussen de beide kennissoorten te kunnen worden aangewezen.

Ook is het niet zo dat de wetenschap aan triviale feiten achteloos voorbijgaat. De bioloog Darwin (1809-1882) maakt in zijn notebook melding van het feit dat hij 'in een zeer weinig bezocht gedeelte der pampas [van een van de Galapagos-eilanden] een inheemsche muis in het dak eener nieuwgebouwde hut' heeft zien leven. En men kan in een historische studie lezen dat op 27 maart 1670 Cornelis Lourisz., een jonge inwoner van het Noord-Hollandse dorp Graft, op een boedelveiling een pot koopt, een bakermat, een kakstoel, een stoel, een turfvat en een kinderdekentje. (Van Deursen 1994: 65) Deze dingen wijzen er dus op dat de wetenschap onder bepaalde omstandigheden ook voor weetjes belangstelling heeft.

Als het verschil niet in de waarheid van de beide soorten kennis ligt, of in de bruikbaarheid ervan, waar ligt het verschil dan wel? Het verschil heeft te maken met het doel van de wetenschappen. De wetenschap zal er in het algemeen naar streven het niveau van de triviale kennis te overstijgen, en juist over die dingen betrouwbare mededelingen te doen die het direct waarneembare niveau van de werkelijkheid te boven gaan. Darwins observatie wordt wetenschappelijk pas interessant als hij blijkt te 
de wetenschap doet uitspraken over iets waarvan we slechts de verschijningsvormen kunnen zien

common sense en wetenschappelijke kennis

Lazarsfelds gedachtenexperiment passen in de bewijsvoering voor een theorie over het ontstaan van de soorten op aarde; en die theorie heeft betrekking op een veel groter aantal exemplaren (en soorten), dan die ene muis die hij op de Galapagoseilanden heeft gezien. Iets dergelijks geldt voor de observatie over de inboedel van Cornelis Lourisz.

De wetenschap, zo kan men generaliserend zeggen, is nieuwsgierig naar aspecten van wat niet met de zintuigen waarneembaar is, en toch gekend kan worden. Ze wil beweringen doen over de verbanden tussen de dingen die tot de realiteit behoren (de vertegenwoordigers van een natuurlijke soort; de dingen die uit de zeventiende eeuw zijn overgebleven), terwijl die verbanden zelf niet zichtbaar zijn (de natuurlijke soorten; het dagelijkse leven in de zeventiende eeuw). Het bestaan van zulke algemene verbanden, treedt - ondanks die onzichtbaarheid - hierin aan het licht dat er voorspellingen omtrent triviale feiten uit kunnen worden afgeleid. Daarmee manifesteren die algemene zaken zich in de waarneembare werkelijkheid. Hoewel iemand een diersoort als zodanig niet kan zien, streeft de wetenschap er naar kennis te produceren over deze op zichzelf onzichtbare zaak. Op dezelfde manier, hoewel niemand de zeventiende eeuw kan zien, produceren historici kennis over de onzichtbare zeventiende eeuw.

Ook voor common sense-uitspraken geldt dat ze niet naar een waarneembare werkelijkheid verwijzen. Maar dat maakt ze nog niet wetenschappelijk. In tegenstelling tot trivialiteiten zijn common sense-uitspraken vaak wel aanvechtbaar, ook al staan ze, zoals we zagen, doorgaans niet ter discussie. Je kunt zeggen dat aan common sense-uitspraken altijd, op het moment dat ze ter discussie gesteld worden, stilzwijgend een woord als gewoonlijk of meestal wordt toegevoegd. Het lijkt zo te zijn dat er altijd een mogelijkheid is ingebouwd om te ontsnappen aan de algemeenheid waarmee ze zijn geformuleerd. Misschien laten mensen zich daarom zo gemakkelijk door common sense-uitspraken misleiden. Ze worden gemakkelijk voor banale waarheden gehouden, ook al zijn ze onjuist. Dit is op een bijzondere wijze aan het licht gebracht door de socioloog Paul Lazarsfeld in een beroemd geworden experiment.

Lazarsfeld (1949) stelde dat menselijk gedrag zeer complex is en daarom moeilijk accuraat te beschrijven. Zo'n wetenschappelijke beschrijving kan al gauw banaal lijken.

For it is hard to find a form of human behavior that has not already been observed somewhere. Consequently, if a study reports a prevailing regularity, many readers respond to it by thinking 'of course that is the way things are'. Thus, from time to time, the argument is advanced that surveys only put into complicated form observations which are obvious to everyone. [...] 
The reader may be helped in recognizing this attitude if he looks over a few statements which are typical of many survey findings and carefully observes his own reaction. A short list of these, with brief interpretive comments, will be given here in order to bring into sharper focus probable reactions of many readers.

1. Better educated men showed more psycho-neurotic symptoms than those with less education. (The mental instability of the intellectual as compared to the more impassive psychology of the-man-inthe-street has often been commented on.)

2. Men from rural backgrounds were usually in better spirits during their Army life than soldiers from city backgrounds. (After all, they are more accustomed to hardships.)

3. Southern soldiers were better able to stand the climate in the hot South Sea Islands than Northern soldiers. (Of course, Southerners are more accustomed to hot weather.)

4. As long as the fighting continued, men were more eager to be returned to the States than they were after the German surrender. (You cannot blame people for not wanting to be killed.)

We have in these examples a sample list of the simplest type of interrelationships which provide the 'bricks' from which our empirical social science is being built. But why, since they are so obvious, is so much money and energy given to establish such findings? Would it not be wiser to take them for granted and proceed directly to a more sophisticated type of analysis? This might be so except for one interesting point about the list. Every one of the statements is the direct opposite of what actually was found. Poorly educated soldiers were more neurotic than those with high education; Southerners showed no greater ability than Northerners to adjust to a tropical climate; [...] and so on.

If we had mentioned the actual results of the investigation first, the reader would have labeled these 'obvious' also. Obviously something is wrong with the entire argument of 'obviousness'. It should really be turned on its head. Since every kind of human reaction is conceivable, it is of great importance to know which reactions actually occur most frequently and under what conditions; only then will a more advanced social science develop.

wat zegt dit experiment over common sense?
Lazarsfeld is hier zo uitvoerig geciteerd omdat alleen dan het gedachtenexperiment werkt: alleen als vastgesteld is dat de meeste van de vier uitspraken vanzelfsprekend zijn, wordt het feit dat ze allemaal onwaar zijn, bijzonder.

Lazarsfelds gedachtenexperiment brengt bijzondere kenmerken van common sense tot uitdrukking. Merk op dat Lazarsfelds experiment niet 
common sense en wetenschappelijke kennis

laat zien dat de common sense-uitspraken, dat wil zeggen de vier beweringen tussen de haakjes, onwaar zijn. Het laat zien dat die beweringen onvoldoende zijn om de vier gegeven beweringen te onderbouwen. De meeste common sense-uitspraken laten zich gemakkelijk inpassen in het beeld dat we van de samenleving en het menselijk gedrag hebben. We scheppen samenhang tussen de dingen in de chaotische wereld door de aanwezigheid te veronderstellen van common sense-regelmatigheden. Dat doen we ook als we verhalen proberen te begrijpen en in de geschiedschrijving. Als het er om gaat een ordening van samenhang aan te brengen in de veelheid van historische verschijnselen, wordt van de samenhang-scheppende kracht van common sense-uitspraken veel gebruik gemaakt.

Het probleem van common sense is evenwel dat we niet weten wat de reikwijdte ervan is. Niemand kan het andere mensen kwalijk nemen dat ze niet dood willen (zie Lazarsfelds punt 4.), maar het is de vraag welke verklarende waarde zo'n algemene uitspraak heeft voor menselijk gedrag. Wetenschappelijke uitspraken maken deel uit van een min of meer systematisch opgebouwd stelsel van uitspraken. Common sense-uitspraken zijn daarentegen vaak 'losse flodders' die op willekeurige momenten in de geest kunnen worden opgeroepen om een verband tussen aspecten van de werkelijkheid te creëren dat voor dat moment voldoende bevredigend is. Mensen zijn snel geneigd ze te onderschrijven, omdat ze zo gauw niet zien welke bezwaren er tegen in te brengen zijn; en welke beperkingen er aan de geldigheid zijn gesteld. Van wetenschappelijke uitspraken daarentegen is doorgaans preciezer bepaald in welk kader ze gelden en op welke gevallen ze wel en op welke gevallen ze geen betrekking hebben.

\section{3}

algemene voorbeelden van pseudowetenschappelijke kennis

voorbeelden van pseudo-alfawetenschap

\section{Wetenschappelijke kennis vs. pseudo-wetenschappelijke kennis}

Er zijn allerlei mensen die pretenderen 'wetenschappelijke' inzichten in de werkelijkheid te hebben die door de 'officiële wetenschap' niet als wetenschappelijk worden erkend.

Astrologen zijn hiervan een goed voorbeeld: zij pretenderen de toekomst te kunnen voorspellen aan de hand van de stand van de sterren. Natuurgenezers, ufologen en parapsychologen zijn andere voorbeelden. We noemen de hier bedoelde kennisgebieden pseudo-wetenschappen. (Zie voor een overzicht Hulspas en Nienhuys 1998; voor een wetenschapsfilosofische benadering van het verschijnsel Derksen 1993)

Ook de letteren kennen deze pseudo-wetenschappelijkheid. Voorbeelden van pseudo-geschiedbeoefening zijn de steeds weer opduikende Auschwitz-Lüge (de idee dat er in de Tweede Wereldoorlog geen holocaust heeft plaatsgevonden), of de idee dat het dagboek van Anne Frank 
een tweede

voorbeeld: pseudomusicologie

een vervalsing is. Verzonnen kennis van historische snit wordt daarbij als wetenschappelijke kennis gepresenteerd, soms met evidente politieke bijbedoelingen. (Lipstadt 1993)

Op twee andere voorbeelden van pseudo-alfawetenschap gaan we nader in. Pseudo-musicologie vinden we in een kabbalistische benadering van het werk van Johann Sebastian Bach. (Karsbergen en Van Houten 1985) Leidende gedachte daarbij is dat Bach op zeer veel plaatsen in zijn muziek als het ware een muzikale handtekening in zijn werk heeft aangebracht. Dat zou aan het licht komen door een numerologische analyse. Iedere letter heeft daarin een getalswaarde, die correspondeert met de plaats van die letter in het alfabet $(A=1 ; B=2 ; C=3$ etc. $)$. De naam Bach is numerologisch verbonden met het getal 14 , de som van $B=2, A=1, C=3$, $\mathrm{H}=8$. Het getal 14, zeggen de genoemde auteurs, is een 'Bach-getal'. Als je de vier getallen vermenigvuldigt, krijg je 48. Ook dat is een Bach-getal. Zo zijn er nog meer Bach-getallen. Karsbergen en Van Houten vinden nu dat veel passages in het werk van Bach bestaan uit 14 noten, of uit groepen noten die met een ander Bach-getal corresponderen. Dat is geen toeval, zo betogen de auteurs. Die passages moeten worden opgevat als verwijzingen naar de componist: zijn naam, zijn geboortedatum en zelfs naar zijn sterfdatum. 'We staan hier voor een groot wonder, waarbij eigenlijk alleen maar een diep stilzwijgen past.' (p. 6o) De 'pseudo-verklaring' van de diepere betekenis van de aanwezigheid van muzikale structuurelementen die beantwoorden aan Bach-getallen, dwingt de auteurs tot een diepere verklaring, die bij Bach bijzondere mentale gaven veronderstelt.

Het is onze persoonlijke mening, dat we niet moeten stellen dat Bach zijn sterfdatum heeft voorspeld. Het gaat veel dieper. Zijn geest had kennis van kosmische wetmatigheden en hij geeft een afspiegeling daarvan in zijn muziek. Zo had zijn geest ook inzicht in zijn eigen levenswetten, met als uiterste consequentie het bewustzijn van zijn eigen sterfdatum. (p. 61)

Zo komt van het een het ander.

Iemand die in staat is muziek te schrijven van zulk een eeuwigheidswaarde [...] moet innerlijk heel dicht bij de diepste en meest essentiële waarden van de schepping staan en zich daarvan waarschijnlijk ook bewust zijn. Gezien het enorme bewustzijn van Bach met betrekking tot het getal in relatie tot zijn kunst is het niet ondenkbaar dat zijn geest heel bewust met kosmische wijsheden verbonden moet zijn geweest, dat hij inzicht heeft gehad in de wetten van de kosmos, het mysterie van het leven en in zijn eigen levenswetten in het bijzonder. (p.6o) 
een derde voorbeeld: pseudo-etymologie

wat is etymologie?

wat is pseudo-etymologie?

een paar voorbeelden

waarom is dit onzin?
Voor dit 'enorme bewustzijn' evenwel is geen andere evidentie beschikbaar dan de veronderstelde waarheid van de numerologische theorie.

Cruciaal in het betoog is dat het voorkomen van groepen noten met een Bach-getal geen toeval is. Dat wordt weliswaar door een statistische analyse ondersteund, maar die schiet ernstig tekort. (Derksen 1993)

Een ander voorbeeld van pseudo-alfawetenschap levert de pseudoetymologie. Wat pseudo-etymologie is, laat zich niet goed uitleggen als we niet eerst stilstaan bij de vraag wat etymologie is. De etymologie is een onderdeel van de taalkunde. In de etymologie onderzoekt men de oorsprong en geschiedenis van woorden. Woorden als (scharen-) sliep en slijpen, of het Duitse Wald en het Nederlandse woud zijn verwant, ze hebben dezelfde wortel, dezelfde oorsprong. De verschillen tussen de woorden berust op klankveranderingen die zich in de loop van de geschiedenis voor sommige taalgebruikers wel, en voor andere niet hebben voorgedaan. Voor de humanisten was de etymologie al een belangrijke methode om de betekenis van woorden te achterhalen. Maar van een wetenschappelijke etymologie is pas sprake vanaf de zeventiende eeuw. De Nederlander Lambert ten Kate geldt als de grondlegger.

Pseudo-etymologen nu construeren allerlei relaties tussen woordvormen die beogen een diepere zin van het woord zichtbaar te maken op basis van het denkbeeld dat 'een naam voor iets niet zomaar uit de lucht komt vallen'. Zo beweren de pseudo-etymologen Hietbrink en Lagendijk (1994) dat het woord rozemarijn de vorm verbergt r-oz-er-mar-ijn, en dus (!) zo is er maar één betekent. En zij construeren een gelijksoortig verband tussen aanstotelijk en en-staat-lelijk; tussen beminnen en bij-mijinnen; akkefietje en ' $h a k$-t-effe-uit-ja' en nog honderden andere.

Deze onzin komt onder andere voort uit het onjuiste denkbeeld dat er 'een natuurlijke juistheid voor de namen der dingen' is; dat de dingen niet toevallig heten zoals ze heten; dat de naam iets zegt over het ding dat met de naam wordt benoemd. De verbastering van de oorspronkelijke vormen zou deze betekenis verduisteren en de pseudo-etymologie zou die oorsprong weer aan het licht brengen. Voor Hietbrink en Lagendijk verbergen allerlei woorden in andere talen Nederlandse vormen. Men overtuige zichzelf:

Het gesproken woord is mondiaal omdat de mond aanvult wat men direct als ooggetuige allemaal zag of wederhoorde. Mensen heten in het Frans niet voor niets: du monde. Het woord iedereen is in het Frans alle monden: tout le monde. Met onze mond wordt alles in de wereld uitgelegd en verstaan. De wereld: le monde. De krant die voor iedereen spreekt heet Le Monde. Alle monden hebben recht van spreken, daarom verschijnt er in Brabant De Stem. En in Duitsland de tijdtong: Zeitung. (Hietbrink en Lagendijk 1994:37) 
bezwaren tegen deze pseudo-wetenschap

algemene eigenschappen van pseudo-wetenschappen

invloed van pseudowetenschap
Hietbrink en Lagendijk zien in deze en dergelijke vormovereenkomsten aanwijzingen dat het Nederlands de oudste taal ter wereld is en dat alle talen van het Nederlands afstammen.

De regels waarmee de afleidingen worden gerechtvaardigd, zijn vanwege hun willekeur zonder verklarende waarde. Ze zijn ad hoc. Hun bereik gaat niet verder dan het gegeven geval. Er wordt geen reden gegeven waarom we zouden moeten geloven dat de Fransen het Nederlandse woord mond gebruiken - en niet het Franse woord bouche dat 'mond' betekent - voor een begrip dat Nederlanders met het woord wereld aanduiden.*

Deze eigenschappen kunnen steeds bij pseudo-wetenschappen worden aangewezen:

- wat toevallig is, wordt een 'diepere' zin verleend;

- de verklaringen zijn ad hoc.

Andere kenmerken waarin pseudo-wetenschappen zich onderscheiden van de wetenschappen, zijn de volgende.

- pseudo-wetenschappen plaatsen zich buiten de wetenschappelijke tradities. Hietbrink en Lagendijk beroepen zich voor een deel van hun woordverklaringen op een werkwijze die in de zestiende eeuw gemeengoed was. Ze leggen geen rekenschap af van het feit dat hun werkwijze tegenwoordig door geen taalkundige meer wordt aangehangen;

- pseudo-wetenschappers schermen zich af van serieuze kritiek; ze geven niet aan wat ze als een geldige verklaring zien. Ze maken hun beweringen immuun tegen tegenwerpingen.

Pseudo-wetenschappers van hun kant betogen vaak dat ze niet op grond van argumenten, maar uitsluitend op grond van 'macht' buiten de wetenschappelijke wereld worden gehouden.

In de pseudo-wetenschappen ontmoeten we allerlei mensen die mee willen rijden op de aanhangwagen van de wetenschap. Soms lukt het ze een tijdlang een academische erkenning te krijgen. Er zijn tijden geweest dat de astrologie een positie had in de kring van de astronomen. Er zijn universiteiten waar de parapsychologie een erkend vak is. Er zijn faculteiten waar stukjes pseudo-musicologie het studieprogramma binnensluipen. Maar meestal is de gevestigde wetenschap onvriendelijk tegen

\footnotetext{
* Voordat men zegt dat dit niet serieus genomen moet worden, zou men zich moeten verdiepen in sommige van de publicaties van auteurs die zich door het werk van Derrida laten inspireren. Hier is een citaat: 'Andrew Parker suggests, for example, that Derrida's concern with marques, with the structure of marks, is an incorporation of Marx.' (Culler 1989: 190) Ik vrees dat dit niet als grapje is bedoeld.
} 
de pseudo-wetenschappers. Dat is zeker zo, als de pretenties pseudo-wetenschappers tot een levensbedreigend gedrag brengen, of als ze valse hoop scheppen zoals dat bij de natuurgenezers kan worden aangetroffen. Dat tolereert de samenleving niet. Dat geldt ook voor de AuschwitzLüge en de idee dat het dagboek van Anne Frank een vervalsing is. De schadelijkheid daarvan wordt zo groot geacht dat het door de rechter verboden is deze gedachten te verspreiden.

Als er geen maatschappelijke risico's aan zijn verbonden, gaat de wetenschap aan het werk van pseudo-wetenschappers meestal schouderophalend voorbij. Sommigen, zoals de leden van de internationale vereniging SKEPTER, uitgevers van het tijdschrift Skepsis, leggen zich toe op principiële kritiek.

\section{4}

journalistieke kennis

verschil met wetenschappelijke kennis

essayistiek

\section{Wetenschappelijke kennis vs. journalistieke kennis}

Op het terrein van de alfavakken is het onderscheid tussen wetenschappelijke kennis en journalistiek of essayistiek wellicht het moeilijkst af te bakenen.

Sommige mensen zijn van mening dat de kennis die de historicus produceert, niet wezenlijk verschilt van wat een journalist maakt. (Bommeljé 1995: 14) Men bedoelt niet dat professionele historici bij tijd en wijle (ook) in kranten publiceren, maar dat de kennis die journalisten dagelijks tot gewone nieuwsberichten verwerken, niet verschilt van de kennis die de wetenschappen (bijvoorbeeld de historische wetenschappen) opleveren.

Het verschil tussen wetenschap en journalistiek moet gezocht worden in de aard van de kennis en de wijze waarop de kennis wordt verantwoord. Journalisten observeren de werkelijkheid direct en van een korte afstand. Het aantal bronnen is vaak beperkt. Historici observeren van een grotere afstand, en ze verwerken een grotere diversiteit van bronnen. Het belangrijkste verschil is echter dat journalistieke kennis niet op-dewijze-van-de-wetenschap wordt gepresenteerd en verantwoord. Een krantenstuk heeft geen voetnoten. Een journalist is niet (altijd) expliciet over zijn bronnen. Het onderzoek is daardoor niet steeds controleerbaar.

Als een publicatie de kennelijke bedoeling heeft (oorspronkelijke) ideeën te presenteren zonder die op de wijze van de wetenschap te onderbouwen, spreken we van een essay. Essays zijn verrassend en verwarrend. De essayist Willem Jan Otten formuleerde het zo:

Je moet alles op alles zetten om zo te schrijven dat mensen in verwarring raken. Dat behoort bij mijn definitie van essayistisch. Je probeert mensen een ongemakkelijk gevoel te geven, omdat je jezelf ongemakkelijk en onzeker voelt. 
in essays zijn de argumenten niet empirisch

kennis en de onderbouwing van kennis

'context of discovery'

'context of justification'

\section{Wetenschappelijke kennis en niet-wetenschappelijke kennis}

De essayistiek wordt zowel door wetenschappers als door niet-wetenschappers beoefend. Het essay wordt als genre in onze cultuur hogelijk gewaardeerd, maar de essayistiek wordt doorgaans niet tot de wetenschap gerekend.

De afwezigheid van een op-de-wijze-van-de-wetenschap verworven en gepresenteerde argumentatie verleent essayistische kennis een nietwetenschappelijk karakter. Er worden in essays voor de denkbeelden wel argumenten gegeven, maar die argumenten zijn niet of onvoldoende empirisch. We zullen nog zien wat daarmee wordt bedoeld. Sommige schrijvers op het gebied van de letteren presenteren hun werk als 'essay'. De indruk bestaat dat ze dit vooral doen als het gaat om werk waarin ze reflecteren op doel en methode van hun vakken, of als ze grootse maar ongewisse verbanden menen te kunnen laten zien.

Interessante voorbeelden van essayistiek, die zich ook er toe lenen om het inzicht aan te scherpen in het verschil tussen essayistische en wetenschappelijke kennis, zijn Sebastian Haffners Anmerkungen zu Hitler (1978) op het gebied van de geschiedenis, of George Steiners After Babel. Aspects of language and translation (1975) op het gebied van de taalkunde en de vertaalwetenschap.

In deze paragraaf werken we de uiteenzettingen van de vorige paragrafen nog wat verder uit. We zagen dat het nuttig kan zijn een onderscheid te maken tussen aan de ene kant een bewering, een vondst, een ontdekking, een idee, en aan de andere kant de wijze waarop de bewering wordt verdedigd, de vondst onderbouwd, de ontdekking gerechtvaardigd. Dit onderscheid staat in de wetenschapsfilosofie bekend als het onderscheid tussen ontdekking en rechtvaardiging-van-een-ontdekking, doorgaans in het Engels benoemd met de termen discoveryen justification.

Overal ter wereld in allerlei omstandigheden krijgen mensen ideeën. Dagelijks gebeurt dat en niet alleen in bibliotheken, archieven of laboratoria. Maar het ontstaan van ideeën, het 'ontdekken' zelf, is voor wetenschapsfilosofen niet interessant. De manier waarop en de omstandigheden waaronder ideeën worden geboren, de context of discovery, onttrekken zich aan onze waarneming, en zeggen niets over de kwaliteit van het idee. Je zult een wetenschapper nooit horen zeggen: 'Dit is een verkeerd idee, want de manier waarop het gevonden is, is verkeerd.; of 'Dat is een goed idee, want het ontstond tijdens de wandeling langs het Damsterdiep.'

Een idee blijkt pas een goed idee als het kan worden gerechtvaardigd. Maar dan treden we in een heel andere sfeer van de wetenschap binnen, 
'idee'vs.'rechtvaardiging van het idee'

niet-wetenschappelijke kennis zou waar kunnen zijn

bezwaren van de wetenschap tegen de waarheidspretenties van de andere kennisgebieden namelijk de sfeer van het systematische zoeken naar argumenten, de context of justification.

Dit verschil tussen 'idee' en 'rechtvaardiging van het idee' is zeer fundamenteel. In tegenstelling tot wat je zou denken is het verschil tussen wetenschappelijke kennis en andere kennis niet in de eerste plaats gelegen in de aard van de ontdekkingen, de inzichten of de ideeën die worden geponeerd. Het verschil is niet in de eerste plaats dat de wetenschap 'ware ideeën' produceert, en die andere kennisgebieden onware, betwistbare of onzekere.

Ook is het verschil tussen wetenschappelijke kennis en niet-wetenschappelijke kennis niet gelegen in de manier waarop de onderzoeker aan de ideeën of vermoedens is gekomen. De context of discovery bepaalt niet of kennis wetenschappelijk kan heten of niet.

Het verschil tussen wetenschappelijke kennis en de kennis van de andere kennisgebieden zit hem hierin dat in de wetenschap ontdekkingen, inzichten, ideeën etc. op een heel speciale wijze worden gerechtvaardigd. Wetenschappen claimen de waarheid dichter te benaderen dan de andere kennisgebieden. Dit komt doordat er in de wetenschappen strenge eisen aangaande de onderbouwing of rechtvaardiging van de kennis worden gesteld.

Eenzelfde bewering zou gedaan kunnen worden door een wetenschapper en door een journalist, of een natuurgenezer, of een ufoloog of door de paus ex cathedra. Het is niet zeer waarschijnlijk, maar het zou kunnen. Het getuigt bijvoorbeeld allerminst van irrationeel historisch gedrag om te zoeken naar de historische waarheid in een mythe. 'Er heeft zich ooit een zondvloed voorgedaan.' 'Er heeft in het Noordwesten van Klein-Azië een stad Troje bestaan' 'De Vikingen “ontdekten” Amerika'. Zulke beweringen zouden zowel historische kennis als mythologische kennis kunnen zijn. Wat de beweringen onderscheidt, is de wijze waarop ze door wetenschappers enerzijds en niet-wetenschappers anderzijds worden onderbouwd. Het bestaan en de aard van de argumentatie maakt de bewering tot een wetenschappelijke. Langs deze lijn van redeneren kunnen ook 'geschiedverhaal' en 'historische roman' van elkaar worden afgebakend. (Ankersmit 1981: 23)

Claimen dat de bewering geopenbaard is, het niet noemen van argumenten, het afschermen van een bewering van toetsing, het formuleren van een bewering in zulke (dogmatische) termen dat hij zich onttrekt aan toetsing, die dingen maken een bewering op zichzelf niet onwaar, maar wel onwetenschappelijk. En daarmee is die kennis voor de wetenschappen gediskwalificeerd.

Niet de waarheid van de bewering is beslissend voor de vraag of we met wetenschap te maken hebben, maar de wijze waarop de kennis is vormgegeven, en de wijze waarop de kennis getoetst kan worden. Als 
twee verschillen tussen niet-wetenschappelijke en wetenschappelijke kennis

rechtvaardiging verleent een idee zijn waarde

wetenschappelijke kennis vertoont een samenhang met andere wetenschappelijke kennis geloof en wetenschap het oneens zijn, of wetenschap en pseudo-wetenschap, of wetenschapper en journalist, of wetenschappers onderling (!) twisten ze niet over de vraag hoe ze aan hun kennis gekomen zijn, maar over de vraag hoe de kennis is onderbouwd, en op grond daarvan over het waarheidsgehalte van het beweerde. Wetenschappers zullen dus nooit onder de indruk zijn van iemand die zegt dat een ontdekking een goddelijke ingeving was. Dat interesseert ze niet (tenzij ze mensen onderzoeken die zeggen goddelijke ingevingen te hebben), maar ze zullen vragen wat voor argumenten er zijn voor de juistheid van de ontdekking.

De systematische aandacht van de wetenschap voor de rechtvaardiging van de geponeerde inzichten zorgt er voor dat aan die inzichten zelf ook een grotere waarde wordt toegekend dan aan de niet onderbouwde. Deze waarde blijkt uit het feit dat anderen erop willen voortbouwen. Wetenschappelijke kennis is van dien aard dat hij systematisch uitbreidbaar is. Wetenschappelijke kennis is kennis die groeit.

Er kwam nog een tweede verschil tussen wetenschappelijke en nietwetenschappelijke kennis aan het licht. In de paragraaf over alledaagse kennis hebben we erop gewezen dat de wetenschappen proberen geen 'losse flodders' te produceren, geen kennis die niet een maximale samenhang vertoont met andere kennis. De wetenschap is niet geïnteresseerd in losse weetjes, maar in verbanden of regelmatigheden. Wetenschappelijke kennis is altijd ingebed in andere wetenschappelijke kennis en maakt dus ook deel uit van een traditie. 


\section{De vorm van kennis}

wetenschappelijke kennis is gemakkelijk te herkennen

wetenschap heeft een talige vorm

eerste voordeel: uitwisselbaarheid van kennis

tweede voordeel: taal maakt redeneren mogelijk

problemen
Wetenschappelijke kennis is gemakkelijk te herkennen. Sla een boek of een tijdschrift open, en een eerste blik is vaak al voldoende om een wetenschappelijke tekst te onderscheiden van een roman, een publiekstijdschrift of een kookboek. De aanwezigheid van formules, grafieken, voetnoten, literatuurvermeldingen wijst op wetenschap. Plaatjes, een fantasievolle lay-out, korte stukjes tekst, dat alles vindt men doorgaans in de wetenschap niet.

Zoveel is zeker: wetenschappelijke kennis heeft een talige vorm; wat onderzoekers ontdekken is iets abstracts dat in een natuurlijke of kunstmatige taal wordt verwoord. Uiteraard kunnen ook grafieken, landkaarten of andere soorten afbeeldingen vormen van kennis representeren. Maar de talige vormen dringen zich het meest op de voorgrond. Taal is het voertuig van de wetenschap. Daar zitten voordelen aan, maar het schept ook problemen.

Een eerste voor de hand liggend voordeel van de talige vorm is dat wetenschappelijke kennis kan worden uitgewisseld. De kennis kan met anderen worden gedeeld.

Een tweede voordeel is specifieker. Wetenschappelijke kennis kan dankzij zijn talige vorm deel uitmaken van redeneringen. En door middel van redeneringen kan nieuwe kennis worden geproduceerd. Dit voordeel komt het scherpst naar voren, als niet een natuurlijke taal wordt gebruikt, maar een formele taal, zoals de wiskunde of de logica die kent. Daar komen we nog op terug. Maar we kunnen ook redeneren in natuurlijke taal. Taal heeft op dat punt een duidelijke voorsprong op (al of niet bewegende) beelden.

Er blijken echter ook problemen te kleven aan het talige karakter van wetenschappelijke kennis. Als de wetenschap er naar streeft de werkelijkheid te leren kennen en de geproduceerde kennis derhalve geacht moet worden de werkelijkheid in een talige vorm te weerspiegelen of in beeld te brengen, dan kan dit beeld van de werkelijkheid ook niet ontsnappen aan de eigenaardigheden van taal. Als voertuig voor inzichten waarmee aanspraak gemaakt wordt op waarheid, heeft taal problematische kanten. Die kunnen we in de communicatie van alledag gemakkelijk de baas. Maar er zijn kunstgrepen nodig om van taal een voertuig voor wetenschappelijke communicatie te maken. 


\section{De 'linguistic turn'}

Sinds het begin van deze eeuw is er in de filosofie een toenemende belangstelling voor 'taal'. Dat begint in Engeland bij mensen als Bertrand Russell, Wittgenstein en G.E. Moore en bij de door hen beïnvloede filosofen van de Wiener Kreis. Zij hadden de indruk dat men in de filosofie alleen verder zou komen als men uit de filosofische vraagstellingen - die traditioneel betrekking hadden op de werkelijkheid - de taalkundige aspecten zou losmaken. Alleen het heel nauwkeurige definiëren en analyseren van het gebruik van woorden zou een methode zijn die de filosofie zou kunnen verlossen uit een patstelling van eindeloze discussies, waarin geen vooruitgang zat. Er zouden door zo'n analyse ook een heleboel filosofische problemen als schijnproblemen worden ontmaskerd. Methodologische helderheid, dat was het doel. In de Ordinary Language Philosophy richtte men zich op een analyse van het gewone natuurlijke taalgebruik. In de Ideal Language Philosophy probeerde men een speciaal voor het denken en de wetenschappen geschikte taal te ontwerpen. Dit streven is verwant aan dat van de Nederlandse signifische beweging. Mogelijk sinds de verschijning in 1968 van een beroemde verzameling essays onder die titel, wordt deze verschuiving in de filosofische belangstelling aangeduid met de term 'linguistic turn'.

Onder invloed van Franse filosofen als Derrida en Foucault, heeft vanaf de jaren zestig de rol van de taal in het denken en de wetenschapsbeoefening opnieuw bijzondere aandacht gekregen. Dat was wonderlijk want de Fransen hadden zich altijd van de taalfilosofie afzijdig gehouden. Hun doel was niet een zuivering van de filosofische methode. Integendeel, hun eigenzinnige en beeldsprakerige taal is eerder een verduistering dan een verheldering van hun ideeën. De Franse filosofen meenden aan te kunnen tonen dat er eigenlijk geen realiteit is, als er niet over gesproken wordt, of anders gezegd, dat er pas realiteit ontstaat als er over gesproken wordt. Met zo'n inzet krijgt de taal een allesbeheersend monopolie.

Omdat veel geesteswetenschappers die Franse filosofen als geestelijk leidsman hebben gekozen, vindt men ook daar nu een grote aandacht voor de afhankelijkheid van taal. Ook voor deze ontwikkeling gebruikt men wel de term 'linguistic turn'.

Deze 'linguistic turn' blijkt uit een overvloed aan aandacht voor betekenis, voor metaforen. De wending gaat ook gepaard met een overvloed aan 'talige' beeldspraak. Men 'leest' een schilderij. Men onderzoekt de 'filmtaal' van Hitchcock. Men vertelt de 'narratio' van de geschiedenis. Men beschrijft de 'intertextualiteit' van de cultuur. Men analyseert bouwwerken die 'in gesprek' zijn met hun omgeving. 
In de volgende paragrafen bespreken we eigenaardigheden en problematische kanten van de talige vorm van kennis die betrekking hebben op woorden en termen (paragraaf 2.1.), op zinnen/beweringen (paragraaf 2.2.), op redeneringen (paragraaf 2.3.) en op teksten (paragraaf 2.4.).

3.1

de aanwezigheid van vaktermen

essentialisme

essenties en woordbetekenissen

\section{De vorm van kennis: woorden en termen}

Wetenschappelijke publicaties bevatten vaktermen. Dat maakt ze moeilijk. Veel mensen vinden dat irritant en vragen zich af of dat noodzakelijk is. We willen proberen dit kenmerk van wetenschappelijk taalgebruik in algemene zin te verhelderen. We beginnen daartoe met iets te zeggen over het essentialisme.

Het essentialisme is de opvatting dat de verschijnselen in de werkelijkheid een essentie hebben, en dat verschillende dingen van dezelfde soort met elkaar in (hun) essentie overeenkomen. Een driehoek bijvoorbeeld, welke vorm die driehoek ook heeft, is een manifestatie van de onwaarneembare driehoek-essentie. Die maakt het wezen van de driehoek uit. Iets dergelijks kan gezegd worden van alle dingen die we in de werkelijkheid tegenkomen. Hoe verschillend honden, boeken, ogen, huizen of vormen van vrijheid ook zijn, ze hebben een niet direct waarneembare essentie gemeenschappelijk. De grenzen tussen deze dingen en de dingen die 'niet-hond', 'niet-boek' etc. zijn, zijn scherp. De dingen zijn verdeeld over scherp van elkaar afgebakende categorieën. Aldus het essentialisme.

Deze opvatting is verbonden met een algemeen idee over de betekenis van woorden. Veel mensen denken dat een woord verwijst naar de essentie van de dingen die met het woord kunnen worden aangeduid. Is het woord driehoek immers niet in het bijzonder geschikt om te verwijzen naar alle driehoeken, van welke vorm dan ook, en juist niet naar dingen die geen driehoek zijn? Dit lijkt een aanwijzing dat de woordbetekenis de verzameling eigenschappen omvat die overeenkomen met de essentie van de driehoek.

Het essentialisme veronderstelt dan ook dat er een directe en objectieve relatie is tussen de scherp afgebakende categorieën in de werkelijkheid en de woorden voor die categorieën. De woorden zouden steeds eenduidig naar de juiste dingen verwijzen (behalve als ze metaforisch, of 'foutief' worden gebruikt). Als dat zo was, dan zou dat natuurlijk voor het gebruik in de wetenschap van onschatbare waarde zijn. Rond 1920 heeft de signifische beweging, een gezelschap vooraanstaande geleerden, geprobeerd grondslagen te vinden voor een zodanige zuivering van de Nederlandse woordenschat dat die geschikt zou worden voor gebruik in wetenschappelijke teksten. Hun uitgangspunt was essentialistisch. 
twee ontwikkelingen

die afbreuk deden

aan het essentialisme

het darwinisme

de prototypie-theorie

woorden hebben geen 'eigenlijke' betekenis

woorden zijn theoriegeladen
Het essentialisme, dat al bij Plato te vinden is, heeft een lange en sterke filosofische traditie. Maar er is aan de reputatie van het essentialisme belangrijke afbreuk gedaan. Wij noemen twee ontwikkelingen. In de eerste plaats heeft het werk van Darwin laten zien dat er in de wereld van de levende wezens geen scherp afgebakende natuurlijke soorten bestaan, maar dat de soorten zich geleidelijk uit elkaar ontwikkelen. (Mayr 1993: 40 e.v.) Er kan daarom niet meer van scherp onderscheiden natuurlijke soorten worden gesproken. In zekere zin weten we niet meer wat een kat is. De eenvoudigste definitie dat een kat is wat uit een kat geboren is, is vanuit het oogpunt van de evolutietheorie niet meer bevredigend. De verschillen tussen een kat en een niet-kat zijn gradueel.

In de tweede plaats is er het werk van de psychologe Eleanor Rosch. (bv. Rosch 1975a, 1975b) Rosch heeft voor allerlei woorden laten zien dat een woordbetekenis niet met een klasse van in essentie overeenkomende dingen geassocieerd moet worden, maar dat een woordvorm verwijst naar een prototypisch exemplaar van die klasse. Met het woord vogel associëren wij eerder iets merelachtigs dan iets pinguïn- of kipachtigs. Een merel is meer een prototypische vogel dan een pinguïn of een kip. Zo heeft een prototypische stoel, voor mij althans, vier poten, en niet één, twee of drie poten, of een gebogen buispoot. Zo zal ook het woord driehoek in eerste instantie naar een prototypische driehoek verwijzen. Mijn prototypie van een driehoek heeft geen stompe hoek.

We moeten dus afstand nemen van het essentialisme, en dit brengt met zich mee dat we het idee moeten opgeven dat er een één-op-één-relatie is tussen de woorden en de categorieën waar de woorden naar verwijzen. Dit sluit aan bij een gevoel dat het niet zo zinvol of vruchtbaar is te discussiëren over de 'eigenlijke' betekenis van woorden. Hoewel het aannemelijk is dat in een cultuur de sprekers van eenzelfde taal met een woord steeds ongeveer dezelfde prototypie associëren - er zijn middelen waarmee dat kan worden vastgesteld - is het allerminst zeker dat dat gebeurt. Er is een zekere grond voor het gevoel dat woorden soms verraderlijk en weinig betrouwbaar zijn.

Terug nu naar het problematische van woorden in de wetenschap. Uit het voorgaande vloeit onmiddellijk voort dat aan het gebruik van de meest simpele woorden een vooropgezet idee verbonden is omtrent het prototypische karakter van de dingen die met die woorden worden benoemd. Daardoor is niet uit te sluiten dat de woorden geladen zijn met een persoonlijk gezichtspunt. Dat gezichtspunt omvat steeds een 'theorie' over de werkelijkheid. Woorden, zegt men, zijn theoriegeladen. Ze brengen een zienswijze van de taalgebruiker met zich mee. Woorden hebben geen objectieve betekenis. Dit betekent dat de beschrijving van de meest simpele dingen niet in theorievrije termen zal kunnen geschieden. Dat geldt zelfs voor zo iets simpels als het woord kat in de filosofische 


\section{Deconstructie}

In de Franse filosofie wordt de onbetrouwbaarheid van de taal op een bijzondere manier gedramatiseerd. Een van die verschijningsvormen daarvan is het deconstructivisme. Het is bedacht door de Franse filosoof Jacques Derrida (1930) en in modieuze teksten zonder kop of staart beschreven.

Deconstructie is in aanleg een theorie van tekstinterpretatie. Het moedigt aan een tekst te deconstrueren. In zijn onschuldigste betekenis wil dit zeggen dat het zaak is een tekst te interpreteren met in het achterhoofd de mogelijkheid dat een schrijver in zijn (m/v) woordkeuze vooroordelen omtrent maatschappelijke verschijnselen verraadt. Het deconstructivisme past, zo gezien, in een cultuur van politieke correctheid en het bijbehorende taalgebruik met de politiek correcte associaties.

We kennen de betekenis van een woord, zeggen de deconstructivisten, omdat we weten wat de plaats van het woord is in het systeem van alle woorden van de taal, en met welke woorden het een oppositie vormt.

'[...] daarbij viel Derrida het volgende op: we achterhalen [...] de betekenis van het woord "man" door na te gaan met welke betekenissen het woord "vrouw" allemaal gekoppeld wordt - welnu, het woord "vrouw" wordt telkens opnieuw gekoppeld met negatief gewaardeerde termen [emotioneel, prikkelbaar, wispelturig, onbetrouwbaar], "man" daarentegen met positief gewaardeerde [kracht, betrouwbaar, zelfverzekerd etc.] (Schrover 1992: 14) Dit ligt in feite niet ver van de prototypietheorie. Met dien verstande dat er daar sprake kan zijn van individuele verschillen tussen sprekers, terwijl de deconstructivisten zulke woordassociaties een bovenpersoonlijk bestaan schijnen toe te kennen.

Het idee van de met vooroordelen beladen woordbetekenis leidt de deconstructionisten tot verstrekkende conclusies. Eigenlijk, zo beweert Derrida, produceert de lezer het literaire werk bij iedere lezing opnieuw. En omdat de relatie tussen de werkelijkheid en de bewering over de werkelijkheid niet vaststaat, is de enige werkelijkheid die er toe doet, de tekst waar de bewering deel van uitmaakt. Er bestaat geen werkelijkheid buiten de tekst. En omdat het systeem van de taal alles omvat, bevat iedere tekst eigenlijk iedere andere.

Het werk van Derrida is invloedrijk en omstreden. Critici vinden zijn formuleringen ondoorzichtig, de empirische onderbouwing gebrekkig, de verankering in een taaltheorie onvoldoende en de taalgrapjes onuitstaanbaar.

Bronnen: Els Schrover, Deconstructie en literatuur; Jonathan Culler, On deconstruction. 
vertaalprobleem

waardeprobleem standaardzin 'De kat zit op de mat'. Daar hebben we al op gezinspeeld. Als we een dier een kat noemen geven we (impliciet) aan dat het van een kat afstamt. Maar zijn we ook niet gecommitteerd aan de opvatting dat ook die kat uit een kat geboren is? En moeten we ook niet toegeven dat ook alle oudere voorouders van die katten katten waren? Maar komt er niet een moment waarop we in strijd komen met de evolutietheorie? En moeten we dus niet concluderen dat het gebruik van het woord kat een theoretische consequentie over het ontstaan van katten verbergt?

Iets dergelijks geldt voor het woord mat. We ontlenen de observatie aan een vraaggesprek in Le Monde van 5/6 februari 1995 met de Amerikaanse filosoof en wetenschapshistoricus Kuhn. Voor het Engelse woord mat bestaat een reeks van Franse equivalenten: un petit tapis, une carpette, une natte, un paillasson, elk met zijn eigen betekenisnuance, elk waarschijnlijk met zijn eigen prototypie. Dit maakt, zegt Kuhn, de zin 'The cat is on the mat' onvertaalbaar naar het Frans. Hij bedoelt dat er in principe moeilijk zekerheid te verkrijgen is over de juistheid van een vertaling. Iets dergelijks zal voor de vertaling naar het Nederlands gelden. We weten wanneer we over een mat of een matje kunnen spreken, of over een vloerkleed, tapijt, kleedje of tapijtje. Weten hoe een prototypische Engelse mat er in de werkelijkheid uitziet, lost het probleem maar gedeeltelijk op.

Iedere vertaler wordt door dit verschijnsel herhaaldelijk voor problemen gesteld. Het probleem speelt uiteraard ook een rol als woorden bedoeld zijn om kennis over te dragen. We noemen het geschetste probleem het vertaalprobleem.

Naast een theoretische lading dragen woorden ook vaak een waarde. Zeer veel woorden en zinnen vertonen een waardeoriëntatie van de spreker. Dat komt goed tot uitdrukking als er voor een zaak meer dan een woord bestaat, en de taalgebruiker dus een keuze voor het ene of het andere woord moet maken.

Het volgende voorbeeld is geënt op dat van Lorenz (1987: 29). Vergelijk de volgende zinnen.

(1) (a) Koning Lodewijk XVI is door het gepeupel vermoord.

(b) Burger Capet is uit naam van het volk door de beul terechtgesteld.

Het gaat in deze zinnen over dezelfde gebeurtenis. Koning Lodewijk XVI is een andere naam voor Burger Capet. En door het gepeupel vermoord worden en uit naam van het volk door de beul terechtgesteld worden verwijzen eveneens naar elkaar overlappende verzamelingen gebeurtenissen. De woordgroepen hebben (gedeeltelijk) dezelfde extensie. Maar het verschil in woordkeuze is ook een verschil in perspectief van de spreker. De 
extensieprobleem

deze problemen

hebben voor sommigen vergaande consequenties termen hebben een verschillende intensie. Iemand met zijn koningsnaam benoemen, als er ook een republikeinse naam bestaat, impliceert een politieke keuze. Iets dergelijks geldt voor de woorden terechtstellen en vermoorden. Het probleem dat hier opdoemt, noemen we het waardeprobleem. Woorden dragen hun eigen waarde. Door de keuze van een woord kan een onderzoeker bewust of onbewust ook die waarde overdragen.

Tot slot wijzen we er nog op dat er in iedere taal veel woorden zijn waarvan het niet duidelijk is aan welke waarneembare werkelijkheid met die woorden kan worden gerefereerd. Het woord taal zelf is zo'n woord, en het woord zestiende eeuw. Dit noemen we het extensieprobleem.

Het soort problemen dat we hier hebben beschreven, heeft sommige filosofen tot de opvatting gebracht dat wetenschappelijke resultaten nooit een universele waarde kunnen hebben, dat ze nooit voor alle mensen en alle tijden kunnen gelden. Men noemt deze zienswijze het relativisme. De wetenschapsfilosofen Kuhn en Feyerabend hebben dat relativisme in de jaren zestig geïntroduceerd. Het relativisme stelt dat de geschiedenis van de wetenschappen twee dingen laat zien.

- er is niet één onveranderlijke wetenschappelijke methode; maar de methode is variabel, en de keuze ervan wordt bepaald door sociale en intellectuele omgevingen waarin onderzoekers werken;

- er is geen onveranderlijke neutrale taal waarmee onderzoeksresultaten kunnen worden beschreven; de door de wetenschap gebruikte termen krijgen steeds een nieuwe inhoud; alternatieve theorieën kunnen niet in elkaars taal worden vertaald en daarom niet worden vergeleken. Daarom kan niet worden bepaald welke theorie de waarheid het dichtst benadert.

De opkomst van het relativisme is gekenschetst als een crisis van de rationaliteit. Het geloof in de vooruitgang van de wetenschap leek erdoor te worden ondermijnd. (Sankey 1997)

Veel van de wetenschapsfilosofische discussies in het laatste kwart van de twintigste eeuw hebben betrekking op de vraag hoe ernstig de dreiging van relativisme moet worden genomen.

communicatieve principes
Voordat men al te snel met relativistische opvattingen meegaat, moet op het volgende worden gewezen. Hoewel er geen zekerheid is dat de betekenis die de een aan een woord verbindt, dezelfde is als de betekenis die een ander er aan verbindt, is het een ervaringsgegeven dat mensen elkaar niet onophoudelijk misverstaan. Om dit te verklaren worden er bepaalde principes te hulp geroepen die op een veelal nog onbegrepen wijze de communicatie in goede banen leiden. 
principe van rationaliteit

welwillendheidsprincipe
Zo is het wel zeker dat ons taalgebruik zeer veel redundantie vertoont. Aspecten van de mededeling verschijnen twee of meer keer in één boodschap. In de zin 'De kapster verfde zijn haar aan de achterkant lichter' wordt impliciet of expliciet in twee woorden over 'haar' gesproken: in kapster en in haar; in twee woorden over 'kleur': in verfde en in lichter. Misschien dat die woorden buiten een context een wisselende interpretatie kunnen krijgen - verven kan schilderen zijn; we kunnen te maken hebben met de haar of met het haar; lichter heeft verschillende betekenissen - maar in de context zullen ze in de goede betekenis begrepen worden en zonder dat er strijdigheid blijkt. Er is daar een principe aan het werk dat zegt dat een taalgebruiker zich in zijn taalgebruik rationeel, met vermijding van innerlijke tegenspraken zal willen gedragen. Men noemt dit het principe van rationaliteit. Hoewel het soms wel denkbaar kan zijn dat de ene taalgebruiker aan een bepaald woord een betekenis verleent die afwijkend is van wat een andere taalgebruiker zou doen, zegt het principe van rationaliteit dat de hoorder geen interne tegenspraak bij de spreker hoeft te verwachten, en zo krijgt de hoorder dus impliciet informatie over de beoogde woordbetekenis. Dit principe hangt ook hiermee samen dat het psychologisch niet erg voor de hand ligt om alle woordbetekenissen los van elkaar te zien. Woorden of hun intensies zijn in de vorm waarin ze in onze hersenen zijn opgeborgen, delen van netwerken. Ook dit zorgt ervoor dat de problemen die in principe voortvloeien uit het bestaan van per individu verschillende prototypieën, in de praktijk van het taalgebruik onder controle blijven.

Een tweede principe wordt zichtbaar in het volgende. Een hoorder zal er in alle gevallen bij gebaat zijn aan te nemen dat de door de spreker gebruikte woorden in betekenis zoveel mogelijk overeenkomen met de betekenis die hij zelf aan de woorden verleent. Zelfs als iemand het heel bont maakt, en van zichzelf zegt dat hij een parkiet is, is de hoorder niet geneigd om de spraakgeluiden waarmee deze boodschap hem bereikt, niet als menselijke spraak, maar als parkietenspraak te interpreteren, dat wil zeggen als een onverstaanbare code die toevallig net zo klinkt als mensentaal, maar niet zo zou hoeven te worden begrepen. De hoorder is er bij gebaat zich tegemoetkomend op te stellen ten opzichte van de spreker. Dit noemt men wel het principe van welwillendheid of 'principle of charity'. De filosoof Donald Davidson heeft dit principe geïntroduceerd.

Making sense of the utterances and behavior of others, even their most aberrant behavior, requires us to find a great deal of reason and truth in them. To see too much unreason on the part of others is simply to undermine our ability to understand what it is they are so unreasonable about. If the vast amount of agreement on plain matters that is assumed in communication escapes notice, it's because the 
shared truths are too many and too dull to bear mentioning. What we want to talk about is what's new, surprising, or disputed. (Davidson 1984: 153)

en elders:

Charity is forced on us; - whether we like it or not, if we want to understand others, we must count them right in most matters. (ibidem: 197)

Het principe van welwillendheid wordt uiteraard door het principe van rationaliteit in evenwicht gehouden. De hoorder zal zich niet door zijn welwillendheid laten verleiden afbreuk te doen aan zijn rationaliteit. De werking van beide principes wordt zichtbaar als een spreker een metafoor gebruikt, en bijvoorbeeld zegt: 'Je bent een engel.' De hoorder zal welwillend zoeken naar een metaforische interpretatie van deze zin, een interpretatie waarvoor aan de zin waarheid kan worden toegeschreven, omdat de hoorder anders zijn rationaliteit zou moeten verloochenen.

Principes als die van rationaliteit en van welwillendheid worden gehanteerd om te verklaren dat de ontsporingskansen in de communicatie beperkt zijn. Verwante principes zijn voorgesteld door Paul Grice, die ook aansprekende voorbeelden presenteert hoe de principes in communicatieve situaties werken. (Grice 1989) Ze zijn in ons sociale en communicatieve vermogen 'ingebouwd'. Hoe ze precies werken is echter niet bekend. Ze hebben dan ook in wetenschapsfilosofische publicaties enigszins het karakter van 'bezweringsformules', die zeggen dat problemen als het vertaalprobleem, het waardeprobleem en het extensieprobleem onder controle zijn.

conventionele oplossingen voor de talige problemen

definiëren
Maar naast deze principes, die ook in het gewone alledaagse taalgebruik een rol spelen, zijn er in de wetenschap allerlei conventies om de problemen waar het talige karakter de wetenschap voor stelt de baas te worden. We noemen er daarvan een viertal.

Men probeert sommige problemen te minimaliseren door woorden in een wetenschappelijke tekst een vooraf bepaalde betekenis te geven. Men definieert. Omdat definities echter ook uit woorden bestaan, maakt men zich door definities soms nog afhankelijker van de weerbarstigheid van de taal.

Bij het gebruiken van definities hoort ook de afspraak dat het gebruik van synonieme woorden zal worden vermeden. Voor iedere zaak, verschijnsel, gebeurtenis is er één en niet meer dan één woord. Daardoor ontstaan vakjargons. Hoe fijner de onderscheidingen, hoe gedifferentieerder de speciale woordenschat die men moet gebruiken om die onderscheidingen aan te duiden. 
Een andere manier om door de taal veroorzaakte problemen, speciaal het extensieprobleem te beteugelen, is operationaliseren. Door te operationaliseren legt men extensies vast. Men zegt bij voorbeeld:

- 'In dit onderzoek versta ik onder Nederlandse beeldende kunstenaars uit de negentiende eeuw alle kunstenaars geboren tussen 1775 en 1875 die voorkomen in Scheens Lexicon' of

- 'In dit onderzoek versta ik onder "de woorden van de Nederlandse taal"

- alle woorden die als lemma, als ingang, voorkomen in de twaalfde druk van Van Dale Groot woordenboek van de Nederlandse Taal,

- of alle woorden die voorkomen in het geautomatiseerd toegankelijke "corpus" woorden van het Instituut voor Nederlandse Lexicologie,

- of alle woorden die in 1994 voorkwamen in de Volkskrant'.

Principieel zijn de verzamelingen zoals ze in het laatste voorbeeld worden geoperationaliseerd, niet hetzelfde. Het aantal woorden van het Nederlands is oneindig. En de verzamelingen woorden in de dikke Van Dale, of in het corpus van het INL, of een complete Volkskrant-jaargang - hoe omvangrijk ook - zijn beperkt, maar niet aan elkaar gelijk. Maar in sommige gevallen kan beredeneerd worden dat de conclusies die zijn gebaseerd op een goede operationalisering van het begrip 'alle woorden der Nederlandse taal' geldig zijn voor de anders ongrijpbare verzameling der Nederlandse woorden zelf.

In een operationalisering krijgt een begrip een nauwkeurig afgebakende praktische extensie, een extensie waarmee te werken valt. Anders gezegd, een in principe oneindige verzameling verschijnselen, wordt door een operationalisering aftelbaar en dus eindig.

Ook het gebruik van 'wiskundige formules', formalismen, het gebruik van $x$ en $y$, van $P$, van $p_{1}$ en $p_{2}$ om op een abstracte manier proposities of entiteiten aan te duiden, moet men in dit licht bezien. Een voorbeeld van een geformaliseerde taal is de rekentaal, de taal waarvan ' $2+2=4$ ' en ' $\left(a^{2}-b^{2}\right)=(a+b)(a-b)$ ' zinnen zijn. Formalismen vertonen een aantal dubbelzinnigheden niet. Het grote voordeel van het gebruik van een formele taal is dat de redeneringen waarin de formele termen optreden, betrouwbaarder worden. Het is gemakkelijker om te redeneren met behulp van formele termen dan met woorden uit de natuurlijke taal vanwege de meerzinnigheid van de laatste.

Ook het probleem dat woorden soms een verschillende intensie hebben, bij gelijkblijvende extensie, (gepeupel/volk; vermoorden/terechtstellen) en dat aan de intensies (gevoels-)waarden gekoppeld zijn, wordt wel geattaqueerd met quasi-formele technieken. 
quasi-formaliseringen

expliciteren

kenmerken van wetenschappelijke teksten

worden deze oplossingen door wetenschappers in het algemeen geaccepteerd?

zijn alle problemen nu dus opgelost?
Een voorbeeld is het volgende. Er wordt in de Nederlandse universitaire wereld bij de geesteswetenschappen wel een onderscheid gemaakt tussen de traditionele opleidingen en de moderne opleidingen. Nu hebben de woorden traditioneel en modern allerlei gevoelswaarden, waarvan het soms gemakkelijk kan zijn om die even niet mee te laten doen. Een techniek is dan om af te spreken dat wat in de werkelijkheid 'traditionele opleidingen' zijn te benoemen als T-opleidingen en de andere als M-opleidingen. De woorden T-opleiding en M-opleiding hebben die gevoelswaarden niet. Uiteraard moeten we voor de formalisering de prijs betalen dat er met formules niet zo gemakkelijk gecommuniceerd kan worden. Het kost veel meer moeite om formules te lezen en te doorgronden dan teksten in een natuurlijke taal. Ook door formaliseringen van het type M-opleiding en T-opleiding wordt een tekst niet gemakkelijker. Bovendien moeten we er rekening mee houden dat geen enkel woord immuun is tegen het gevaar bezet te raken met connotaties; als we lang door zouden gaan te spreken van T-opleidingen en M-opleidingen zouden ook die termen weer gevoelswaarden gaan dragen.

Nog een vierde conventionele manier waarmee wetenschappers de problemen van het talige medium willen beteugelen is de methodologische regel: maak je vooronderstellingen expliciet, als het vermoeden bestaat dat ze de lezer bij het begrip van de tekst kunnen misleiden. Dat wil zeggen, maak van het vooronderstelde een aparte bewering, desnoods ten koste van de vloeiende leesbaarheid van de tekst.

Door de toepassing van al deze middelen krijgen wetenschappelijke teksten kenmerkende uiterlijke hoedanigheden. De aanwezigheid van formules, de aanwezigheid van vaktermen en geformaliseerd taalgebruik, de explicietheid, het gebrek aan stilistische variatie, al die kenmerken vloeien voort uit de behoefte om de problematische kanten van de natuurlijke taal voor het verwoorden van wetenschappelijke kennis te onderdrukken. Wetenschappelijke teksten, zo wordt wel gezegd, zijn daardoor esoterisch: alleen voor ingewijden bestemd.

Aan de wetenschappelijke publicaties te zien worden de genoemde oplossingen in het algemeen door wetenschappelijke onderzoekers gebruikt. Maar er zijn er ook die dit niet doen. Er zijn er die op de kwaliteiten van de natuurlijke taal vertrouwen. Historici bijvoorbeeld. Zeer veel historische publicaties zijn betrekkelijk vrij van vakjargon, geformaliseerd taalgebruik en al te grote explicietheid met betrekking tot hun vooronderstellingen. Historici vermijden lang niet altijd waardedragende woorden of woorden met een politieke of maatschappelijke connotatie. Het lijdt geen twijfel dat dit te maken heeft met het soort kennis dat als historische kennis geldt. Daar komen we nog op terug.

Met de gepresenteerde hulpmiddelen denken wetenschappers in staat te zijn in taal kennis te presenteren die tegelijkertijd betrouwbaar is en 
open voor kritiek. De praktijk bewijst dat ze daarin redelijk succesvol zijn. Dat neemt niet weg dat het aantal filosofische publicaties over deze problematiek nog altijd toeneemt.

3.2

beweringen

algemene vs. singu-

liere beweringen

algemene beweringen

\section{De vorm van kennis: beweringen}

Beweringen zijn de kleinste eenheden van kennis. Een wetenschappelijke bewering is een zin die door een wetenschappelijk onderzoeker kandidaat gesteld wordt om 'waar' geacht te worden. In het Engels spreekt men van 'beliefs' of 'propositions'. Andere termen zijn wel: vermoeden, uitspraak of kennisuitspraak. Om waar of onwaar genoemd te kunnen worden moeten de beweringen een correcte vorm hebben. Beweringen hebben steeds de vorm van mededelende zinnen: vraagzinnen of uitroepen zijn geen beweringen; het is ook onzinnig om ze 'waar' of 'onwaar' te noemen. Beweringen kunnen uiteraard waar of onwaar zijn, maar ze kunnen, als ze goed zijn geformuleerd, niet tegelijkertijd waar en onwaar zijn.

Het is zinvol een onderscheid te maken tussen algemene of generaliserende beweringen enerzijds, en singuliere beweringen anderzijds.

Algemene of generaliserende beweringen doen uitspraken over iets dat altijd het geval is. Een paar voorbeelden van algemene beweringen:

(2) (a) Nederlandse schilderijen uit de zeventiende eeuw hebben een verborgen betekenis.

(b) In Nederlandse zinnen staan onderwerp en persoonsvorm altijd of allebei in het enkelvoud of allebei in het meervoud.

(c) Wie zich nooit heeft afgevraagd wiens visie in een verhalende tekst wordt weergegeven, zal het spel van verschillende visies in romans steeds ontgaan. (naar Van Luxemburg, Bal, Weststeijn (1981))

(d) In 1994 vermeldde (nog) geen enkel Nederlands woordenboek het woord 'e-mailen'.

(e) Regisseurs van expressionistische films experimenteerden met camera-instellingen en scherpe zwart-wittegenstellingen in de belichting.

De zinnen (2) generaliseren achtereenvolgens over (alle bestaande, bekende of onbekende) Nederlandse schilderijen uit de zeventiende eeuw, 
(alle denkbare) Nederlandse zinnen, (alle denkbare) lezers-van-verhalende-teksten, (alle in 1994 bestaande) Nederlandse woordenboeken, en (alle) regisseurs van expressionistische films. Ze kunnen met behulp van als-zinnen worden geparafraseerd. De zin (2)(b) zegt bijvoorbeeld dat als iets een onderwerp is en als het meervoudig is dat dit onderwerp dan vergezeld gaat van een meervoudige persoonsvorm, tenminste in het domein van de Nederlandse zinnen.

Tegenover algemene of generaliserende beweringen staan singuliere of bijzondere uitspraken. Die hebben betrekking op één gebeurtenis, op de toestand van een bepaalde zaak of stand van zaken, of op enkele (maar niet alle) gebeurtenissen, zaken etc. in een bepaald domein. Voorbeelden vindt men bij (3).

(3) (a) De Brusselse advocaat Verlooy klaagde in 1788 over de achteruitgang van het Nederlands dat in zijn stad de status van 'straet-tael' gekregen had. (Van der Wal 1992: 391)

(b) De tweede oliecrisis had heel andere gevolgen voor de rentestand dan die van 1973. (Van Zanden en Griffiths 1989: 261)

(c) De held van Temesa van Simon Vestdijk speelt in de Griekse Oudheid.

(d) De twaalfde druk van Van Dale vermeldt het woord 'e-mailen' niet.

Singuliere beweringen hebben betrekking op unieke gebeurtenissen (3) (a) en (3) (b) of unieke standen van zaken (3)(c) en (3)(d). Het bijzondere van singuliere beweringen is dat ze soms direct corresponderen met de waarneembare werkelijkheid. De juistheid of onjuistheid van de bewering (3)(d) lijkt bijvoorbeeld onmiddellijk aan de werkelijkheid te kunnen worden getoetst.

Er zijn allerlei zinnen waarin het generaliserende of singuliere karakter niet gemakkelijk herkenbaar is. We vertrouwen er echter op dat we met de hier gegeven globale aanduiding kunnen volstaan.

algemene uitspraken zijn 'waardevoller' dan bijzondere
Twee opmerkingen zijn hier belangrijk. De eerste is deze. In de wetenschap geldt in het algemeen dat generaliserende uitspraken 'waardevoller' zijn dan enkelvoudige. Het doel van de wetenschap is eerder algemene uitspraken te vinden dan singuliere. Hoe algemener, hoe beter. Hoe meer verschijnselen er onder een bewering vallen, hoe meer 'kennis' er over de werkelijkheid in de ene bewering vervat is.

Het tweede dat in samenhang met de singuliere beweringen moet worden vermeld, is dat de cultuurwetenschappen vaak uitspraken over 
cultuurweten-

schappen zijn in het

unieke geïnteresseerd

statistische en

waarschijnlijkheids-

beweringen

synthetische en

analytische

beweringen

streeft de wetenschap naar de productie van analytische beweringen? 'unieke' dingen zullen willen doen - en dus singuliere beweringen zullen willen gebruiken - omdat hun onderzoeksobjecten nu eenmaal unieke objecten, unieke gebeurtenissen, unieke processen of unieke standen van zaken zijn.

Naast algemene en singuliere uitspraken bestaan er ook statistische en waarschijnlijkheidsbeweringen. Een voorbeeld van een statistische bewering is de volgende zin.

(4) (a) In 1930 verklaarde 34,9\% van de bewoners van de Amsterdamse wijk Kattenburg niet tot een kerkgenootschap te behoren. (naar De Lange 1995)

Deze zin heeft geen betrekking op een complete verzameling gevallen, of op een uniek geval, maar zegt voor welke proportie van de Kattenburgers de bewering geldt dat ze niet tot een kerkgenootschap behoren. De zin zegt impliciet dat de waarschijnlijkheid of de kans, dat in 1930 een bewoner van Kattenburg verklaarde niet tot een kerkgemeenschap te behoren, $34.9 \%$ is. Hier is de statistische uitspraak omgezet in een waarschijnlijkheidsuitspraak.

Statistische en waarschijnlijkheidsuitspraken worden vormelijk gekenmerkt door de aanwezigheid van woorden als soms, sommige $(n)$, bijna altijd, vaak, $75 \%$ van de gevallen, vele $(n)$ etc.

Soms is het zinvol een onderscheid te maken tussen synthetische en analytische beweringen. Analytische beweringen zijn beweringen die waar zijn op grond van de betekenis van de in die zin gebruikte termen. Voorbeelden zijn 'Een vrijgezel is ongetrouwd'; of 'Deze schimmel is wit'. De woorden 'vrijgezel' en 'schimmel' omvatten de eigenschappen 'ongetrouwd', resp. 'wit'. En dat bepaalt het 'nogal wiedes'-karakter van de analytische zinnen. Synthetische zinnen zijn niet-analytisch.

In de wetenschapsfilosofie is de vraag gesteld of niet een heleboel kennis bestaat uit analytische zinnen; of wetenschappelijke onderzoekers er eigenlijk niet doorlopend op uit zijn begrippen (die in het dagelijkse leven gebruikelijk zijn) uit te leggen, dat wil zeggen van een inhoud te voorzien en zo dus alsmaar meer analytische zinnen te produceren; kennis te produceren die analytisch waar is. De volgende voorbeelden om dit te illustreren zijn ontleend aan De Vries (1985: 74).

(5) (a) Militairen dragen een identificatieplaatje bij zich, waarop rang en land van herkomst staan vermeld.

(b) Nederlanders die tot de lage inkomensklassen behoren verzorgen hun gebit slecht. 
De bewering (5)(a) stamt uit het oorlogsrecht. Militairen zijn in dat recht gedefinieerd als de mensen die een identificatieplaatje dragen. De bewering is dus analytisch waar. Iemand die geen identificatieplaatje met rang en land van herkomst draagt, is eenvoudig geen militair. De bewering (5) (b) zou echter best door zorgvuldig empirisch onderzoek van (een relevante deelverzameling van) de Nederlandse bevolking kunnen zijn vastgesteld. Dan is het een synthetische bewering. Maar dit is alleen dan zeker als er een manier is om de 'hoge' en 'lage' inkomensklasse van $\mathrm{Ne}$ derlanders vast te stellen, die onafhankelijk is van de gebitsgesteldheid. Denkbaar is immers dat we de gesteldheid van de gebitten al in de definitie van de Nederlander die tot de lagere inkomensklasse behoort, hebben betrokken. Er zijn nu mensen die zeggen dat als (5b) waar is, we een essentiële eigenschap van mensen van de lagere inkomensklasse hebben vastgesteld. We zouden 'slechts' een aspect van de betekenis van de woordgroep 'Nederlanders die tot de lagere inkomensklasse behoren' hebben vastgesteld.

Men kan zich moeilijk aan de indruk onttrekken dat hier een essentialistische visie op woordbetekenis verondersteld wordt. Vergelijk om dat in te zien nog de zin (2)(e), hier herhaald.

(2) (e) Regisseurs van expressionistische films experimenteerden met camera-instellingen en scherpe zwart-wittegenstellingen in de belichting.

Pas als er geloof gehecht wordt aan de mogelijkheid dat het tot de essentie behoort van 'regisseurs van expressionistische films' dat ze experimenteren met camera-instellingen is er in (2)(e) sprake van een analytische zin. Maar op het moment dat men zich voorstelt dat het ook anders had kunnen zijn, met andere woorden als men zich voorstelt dat dit type experimenten niet noodzakelijk waren voor het expressionistische filmen, dan verdwijnt ook het analytische karakter van deze zin.

\section{De vorm van kennis: redeneringen}

In de vorige paragraaf hebben we stilgestaan bij enkele eigenaardigheden van de kleinste eenheden van kennis: beweringen. In deze paragraaf bezien we eigenschappen van enkele vormen van samenhang tussen beweringen.

redeneren is kennis produceren

Een redenering is een geheel van beweringen dat door logische bewerkingen een samenhang verkrijgt en tot een conclusie leidt. De conclusie is ook weer een bewering. En die kan gelden als nieuwe kennis. Redeneren is derhalve een vorm van kennisproductie, en om kennisproductie, zo 
uit algemene beweringen kunnen singuliere beweringen worden afgeleid

drie voorbeelden

deductie

ook uit singuliere beweringen kunnen nieuwe beweringen worden afgeleid

sommige singuliere beweringen corresponderen met de werkelijkheid zeiden we, is het in de wetenschappen allemaal begonnen. We zullen in deze paragraaf een aantal fundamentele redeneerstappen demonstreren, met name deductie en inductie.

Voor onze uiteenzettingen over deductie sluiten we aan bij het in de vorige paragraaf geïntroduceerde onderscheid tussen algemene en singuliere beweringen. Algemene beweringen hebben de eigenschap dat er singuliere beweringen uit kunnen worden afgeleid of gededuceerd.

Als iemand beweert dat alle Nederlandssprekenden weten dat het woord hersenen een meervoud is, dan kan uit die bewering worden afgeleid dat mijn onderbuurman Hans, die Nederlands spreekt, weet dat hersenen een meervoud is. Je kunt zeggen dat dit laatste in de algemene bewering ligt opgesloten. Zo ook als iemand beweert, dat alle landen van Europa gedurende het midden van de zeventiende eeuw opstanden, oorlog, burgertwisten en andere vormen van sociale onrust kenden, dan kan uit die bewering worden afgeleid dat Bohemen in het midden van de zeventiende eeuw een opstand, oorlog, burgertwist of een andere vorm van sociale onrust heeft meegemaakt. En nog een derde voorbeeld: als iemand beweert dat regisseurs van expressionistische films experimenteerden met camera-instellingen en scherpe zwart-wittegenstellingen in de belichting, dan houdt die bewering in dat de expressionistische filmer Fritz Lang, regisseur van Metropolis (1926) en M (1931), met camera-instellingen en zwart-wittegenstellingen in de belichting heeft geëxperimenteerd

Deze voorbeelden demonstreren een bepaalde stap in een redenering. Zo'n stap wordt deductie genoemd. De waarheid van de bijzondere bewering zit als het ware in de algemene bewering opgesloten. Als de algemene bewering waar is, dan is de door deductie uit die algemene bewering afgeleide singuliere bewering ook waar.

Als we iets nader toekijken, dan zien we dat niet alleen algemene beweringen zo'n stap toelaten. Ook uit singuliere beweringen kunnen soms andere singuliere beweringen worden gededuceerd. Opnieuw een voorbeeld. Als bekend is dat Hans weet dat hersenen een meervoud is, dan weten we ook dat er iemand is die weet dat hersenen een meervoud is. Op dezelfde manier laat de bewering: 'Van de $100 \mathrm{ja} / \mathrm{nee-vragen} \mathrm{had} \mathrm{ik} \mathrm{er} \mathrm{niet}$ meer dan 20 fout', de afgeleide bewering toe: 'Ik had in ieder geval 80 vragen goed.' Ook hier zit de waarheid van de tweede bewering steeds in de eerste opgesloten. De eerste bewering omvat als het ware de tweede.

Deductie is dus het proces waarmee op grond van een bewering tot de waarheid van een nieuwe bewering kan worden besloten, omdat de informatie van de tweede al in de eerste ligt opgesloten. In tegenstelling tot algemene beweringen kunnen singuliere beweringen in sommige gevallen - zoals we geconstateerd hebben in paragraaf 2.2. - getoetst worden aan de werkelijkheid. In sommige gevallen kan van een singuliere bewering worden vastgesteld dat deze correspondeert met de werkelijkheid. 
een voorbeeld

een algemene bewering laat soms de afleiding van allerlei andere beweringen toe
Door deductie vinden we dus een manier om de zekerheid te vergroten aangaande het waarheidsgehalte van een algemene bewering. Wil een algemene bewering waar zijn, dan is een minimale eis dat er geen beweringen uit afgeleid kunnen worden die in strijd zijn met de werkelijkheid. Als we dus een bewering hebben waarvan we niet rechtstreeks kunnen vaststellen of die correspondeert met de werkelijkheid, dan kunnen we proberen uit die bewering singuliere beweringen af te leiden, en bekijken of die singuliere beweringen corresponderen met de werkelijkheid.

Als we willen weten of bewering

(2) (d) In 1995 vermeldde (nog) geen enkel Nederlands woordenboek het woord 'e-mailen'.

waar is, dan kunnen we uit die bewering singuliere beweringen afleiden die ieder betrekking hebben op een woordenboek dat in 1995 reeds bestond, en bezien of dat woordenboek het woord e-mailen vermeldt. Deductie levert derhalve in beginsel een mogelijkheid om vermeende kennis, een vermoeden of een idee te toetsen aan de werkelijkheid.

Kijken we iets preciezer. In den beginne is er een vermoeden, een idee, een voorstelling hoe de werkelijkheid ongeveer in elkaar zou kunnen zitten. Omdat dit vermoeden een talige vorm heeft, kunnen er uit dit vermoeden logisch allerlei beweringen worden afgeleid. De mogelijke waarheid van het vermoeden verbergt als het ware de mogelijke waarheid van een aantal andere beweringen. Die beweringen laten zelf ook weer een aantal deducties toe. En die door deductie gevonden beweringen ook, enzovoort en zo verder.

We kunnen dit afbeelden als een boom.

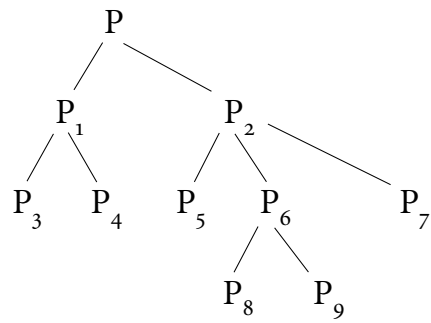

Figuur 1 Boom van deducties

de waarheid van $P$ Stel we beginnen met vermoeden P. Alle knooppunten in deze boom stellen beweringen voor. En alle takken die uit een knooppunt komen, zijn steeds deducties vanuit die ene knoop. Alle beweringen kunnen logisch afgeleid worden uit het vermoeden P. Dit betekent dat de waarheid van P de waarheid van alle knooppuntsbeweringen mede omvat. Merk evenwel 
het begrip

'empirische inhoud'

doorstaat een

bewering een toets, dan heet die bewering 'bevestigd' of 'ondersteund'

hoe neemt de zekerheid van een bewering toe? een voorbeeld op dat er niet zomaar een einde komt aan de boom. De boom kan oneindig ver uitgroeien. Hoever? Dat is mede afhankelijk van de creativiteit van de onderzoeker. Een aantal van de beweringen die uit $\mathrm{P}$ kunnen worden afgeleid, zijn toetsbaar. Voorzover het gaat om de waarheid van P, zijn alleen deze toetsbare beweringen die uit $\mathrm{P}$ kunnen worden afgeleid, belangrijk. De som van die beweringen noemen we de empirische inhoud van P. De beweringen die we uit P kunnen afleiden, maar die zelf niet toetsbaar zijn - en dus niet tot de empirische inhoud van P behoren kunnen we gebruiken als bron van deducties, waarvan er mogelijk wel een aantal toetsbaar zijn. De empirische inhoud van die beweringen behoort vanzelf tot de empirische inhoud van $P$.

De zekerheid van $P$ neemt toe, naarmate meer van de empirische inhoud getoetst is, en de toets een positieve uitkomst had. We zeggen dat er voor P steun of bevestiging is gevonden in de feiten. We zullen dit verder aan de hand van een voorbeeld toelichten. Het is een kunstmatige reconstructie van een redenering, die in de werkelijkheid heel anders zal verlopen.

Laten we aannemen dat we onzeker zijn over de vraag of het Nederlandse woord hersenen een meervoudig woord is, bijvoorbeeld omdat we de vorm ${ }^{\star}$ hersen niet kennen. Een vermoeden zou dan geformuleerd kunnen worden als (6)(a).

(6) (a) Mensen die het Nederlands als moedertaal hebben geleerd, weten dat hersenen een meervoud is.

Bezie dan de volgende deductieve redenering.

(6) (a) Mensen die het Nederlands als moedertaal hebben geleerd, weten dat hersenen een meervoud is.

(b) Hans weet dat hersenen een meervoud is.

Gesteund door de wetenschap dat Hans het Nederlands als moedertaal heeft geleerd, kunnen we (6)(b) zien als een conclusie uit (6)(a), door deductie uit (6) (a) verkregen. (6)(b) is een singuliere bewering. Merk evenwel op dat we het beweerde in (6)(b) niet rechtstreeks in de werkelijkheid kunnen vaststellen. Je kunt niet rechtstreeks zien dat iemand iets weet. (6)(b) is als zodanig niet toetsbaar. Met de deductieve stap zijn we dus niet veel opgeschoten. We moeten een manier vinden om de kennis van Hans zichtbaar te maken. Dat zouden bijvoorbeeld de vaststellingen (6)(c) en (6)(d) kunnen zijn.

(6) (c) Hans die in Nederland door Nederlands sprekende ouders is opgevoed, hebben we de woorden hersenen en hersentjes horen gebruiken. 
(d) Hans antwoordde 'neen', toen wij hem vroegen of hij ooit het woord hersenentjes had gehoord of gelezen, en of hij het zelf zou gebruiken.

(6)(c) en (6)(d) zijn vormen van gedrag, die te interpreteren zijn als zichtbaar gemaakte kennis van Hans. We kunnen ze echter niet rechtstreeks afleiden uit (6)(b). Ze zijn alleen met (6)(a) en (6)(b) te verbinden als we andere beweringen te hulp roepen, die zorgen voor een samenhang. Dat zouden beweringen als de volgende kunnen zijn.

(6) (e) Iemand die een bepaald taalverschijnsel gebruikt, beschikt over het vermogen dat taalverschijnsel te gebruiken.

(f) Iemand die over het cognitieve vermogen beschikt een taal te gebruiken, heeft het vermogen te beoordelen of een willekeurig taalachtig verschijnsel tot die taal behoort etc.

Met behulp van zulke beweringen zijn de beweringen (6)(c) en (6)(d), die een rechtstreeks waarneembaar stukje werkelijkheid beschrijven, logisch te verbinden met de beweringen (6)(a) en (6)(b), die dat niet doen.

Als we dus beweringen betreffende de niet rechtstreeks waarneembare werkelijkheid willen staven, zullen we een redenering moeten bouwen, waarin een verbinding wordt aangebracht tussen deze beweringen en beweringen die wel rechtstreeks waarneembare facetten van de werkelijkheid bestrijken.

beweringen, deducties en theoretisch kader

redeneringen
In termen van de eerder geïntroduceerde boom van deducties moeten we concluderen dat zo'n enkele boom onvoldoende is om te begrijpen hoe door deductie zekerheid groeit. We moeten concluderen dat dit alleen gebeurt als het vermoeden $(\mathrm{P})$, om welks zekerheid het ons te doen is, ingebed is in een reeks van vermoedens die niet ter discussie staan. In ons voorbeeld zijn de beweringen (6)(e) en (6)(f) daar voorbeelden van. De zekerheid die door het positieve resultaat van de toetsing toeneemt, is afhankelijk van het theoretische kader waarin het onderzoek plaats vindt. Theoretisch kader en vermoeden moeten in samenhang worden gebracht. Die samenhang heeft de vorm van een redenering.

In een redenering zijn een reeks beweringen aan elkaar verbonden. De wijze waarop beweringen in een redenering zijn verbonden, is die van de logica. De volgorde van de beweringen in een redenering is willekeurig, en niet van invloed op de correctheid ervan.

Tussen twee willekeurige beweringen $\mathrm{p}$ en q kunnen de volgende relaties bestaan:

- de negatie: de bewering $\mathrm{q}$ is de ontkenning van de bewering $\mathrm{p}, \mathrm{d} . w . z . \mathrm{q}$ is niet-p; p en q zijn niet tegelijkertijd waar; 
- de conjunctie: twee beweringen zijn door en verbonden. Als p waar is en als q waar is, dan is ook p en q waar;

- de disjunctie: twee beweringen zijn door of verbonden. Of p is waar, of $\mathrm{q}$, maar niet allebei;

- de implicatie: de als...dan-relatie. Als p waar is, dan is q waar.

een redenering heet niet waar of onwaar, maar correct of nietcorrect

de geproduceerde kennis is tweeërlei:

trivialiteiten en ...

... toegenomen zekerheid
Beweringen die op deze wijze door conjunctie, disjunctie of implicatie verbonden zijn, kunnen zelf ook weer in hun geheel als lid van een dergelijke relatie optreden. Hetzelfde geldt voor de negatie van die beweringen.

Van een redenering zegt men niet dat hij waar is. Dat zegt men van beweringen. Als een redenering geen strijdigheden bevat, wordt die redenering juist, correct, logisch of geldig genoemd. Zoals we zeiden, zijn redeneringen een middel om kennis te produceren. We moeten nu nog eens terugkijken, naar wat de nieuw geproduceerde kennis in (6) eigenlijk is.

Die blijkt van tweeërlei aard. We begonnen met een idee, een vermoeden. Dat hebben we verwoord in (6)(a). Dit vermoeden bracht ons onderzoek op gang: we werden gedwongen 'kennis' te produceren. Als eerste produceerden we de afleiding (6)(b). Dit was ook niet meer dan een vermoeden, omdat alleen de onzekere bewering (6)(a) er aan ten grondslag ligt. We kunnen de werkelijkheid van (6)(b) niet rechtstreeks waarnemen. Het toetsen van dit vermoeden leidde tot het gerichte waarnemen van het gedrag van Hans. (6)(c) en (6)(d) doen daar verslag van: in ons onderzoek zijn (6)(c) en (6)(d) nieuw geproduceerde kennis. Voordat we ons het hoofd braken over ons 'probleem' hadden we op deze dingen niet gelet. Maar (6)(c) en (6)(d) zijn op zichzelf trivialiteiten. Die kunnen moeilijk het doel van het onderzoek heten. Daarom moeten we nog een paar stappen nemen om te kunnen zeggen welke nieuwe kennis er nog meer geproduceerd werd. We verbonden daarvoor in een redenering (6)(c) en (6)(d) via (6)(e) en (6)(f) aan (6)(b).

Wat is het effect daarvan? Dat wat aanvankelijk een vermoeden was, is nu zekerder geworden. Weliswaar is de bewering (6)(b) afhankelijk geworden van de gevonden juistheid van (6)(c) en (6)(d) en de veronderstelde juistheid van de verbindende beweringen (6)(e) en (6)(f). Maar in dit theoretisch kader is de kennis die we nu geproduceerd hebben te kenschetsen als de toegenomen zekerheid van (6)(b).

Als de zekerheid van de bewering (6)(b) dan is toegenomen, ligt het in de rede om te bezien of hiermee nu ook de zekerheid van de bewering (6) (a) gegroeid is. Wat kan daarover worden gezegd?

Allereerst dit. Het is niet zo dat we zomaar mogen concluderen dat iets bij alle mensen het geval moet zijn, als het bij Hans het geval is. Hans heeft tal van eigenschappen en karakteristieke dingen die alleen maar voor hem gelden en voor niemand anders, en wie zegt ons dat we uit onze 
inductie

het gewone van inductie

inductie garandeert geen waarheid: het inductieprobleem

inductie en deductie vergeleken waarnemingen $(6)(c)$ en $(6)(d)$ kunnen besluiten tot iets dat voor alle mensen zou gelden.

Het ligt voor de hand om te proberen of we soortgelijke dingen als we in $(6)(c)$ en $(6)(d)$ voor Hans hebben vastgesteld, ook voor andere (proef-)personen kunnen vaststellen. Daaruit zouden we dan kunnen concluderen dat ook Jan, Hannes, Jean en John 'weten' dat hersenen meervoud is. We zouden dus aan de bewering (6)(b) over Hans nog een hele reeks van beweringen over andere Nederlandssprekenden kunnen toevoegen. Allemaal singuliere beweringen.

En dan? Het is verleidelijk om te denken: als we dit nu maar in een voldoende aantal gevallen doen, dan mogen we op een gegeven moment de stap maken naar het algemene van (6)(a). We zouden op basis van een 'voldoende' aantal bijzondere gevallen willen concluderen tot de waarheid van het algemene.

Mag dat? In het dagelijkse leven maken we zo'n redeneerstap talloze malen. Als je tweemaal lekker vers brood bij de bakker hebt gekregen, denk je al gauw dat het brood bij deze bakker altijd lekker vers is. En je hoeft maar een paar maal vertraging met de trein te hebben gehad om te zeggen dat de trein altijd te laat is.

De redeneerstap die hier wordt gemaakt, wordt inductie genoemd. Inductie is het trekken van een algemene conclusie op basis van een beperkt aantal gevallen.

Er is een groot probleem met inductie. Hoe vaak we ook in het dagelijkse leven de stap van een aantal bijzondere gevallen naar het algemene maken, hoe vaak we ook in de praktijk een inductieve werkwijze volgen, we kunnen niet waarmaken dat de conclusie die door middel van inductie wordt bereikt, $100 \%$ waterdicht is. We kunnen immers wel van honderdduizend Nederlanders vaststellen, dat ze net als Hans weet hebben van het meervoudige hersenen, maar dat betekent niet dat dat voor de volgende in de rij ook geldt. De sprong van 'een aantal malen' naar 'alle' is niet salva veritate (d.w.z. in de zekerheid dat we de waarheid zullen behouden) te maken. Dit wordt het inductieprobleem genoemd. We kunnen niet op basis van de waarheid van een reeks van singuliere beweringen concluderen tot de waarheid van de algemene vorm van deze bewering. Dit heeft grote consequenties voor de waarheidsaanspraken van wetenschappen.

Er is dus een groot principieel verschil in de betrouwbaarheid van deductie en inductie. Over deductie merkten we op: als de overkoepelende bewering waar is, dan is de door deductie uit die overkoepelende bewering afgeleide bewering ook waar. $\mathrm{Nu}$ zien we echter dat we over inductie niet iets soortgelijks kunnen zeggen. De conclusie van een inductieve redenering is altijd onzeker. Hoe groot we de verzameling bijzondere gevallen ook maken, er zal altijd in principe de mogelijkheid zijn dat dat 
is inductie dus onbruikbaar?

wat levert de redenering uiteindelijk op?

hypothetisch-deductieve werkwijze

abductie wat over de bijzondere gevallen kon worden vastgesteld, voor een (nog) niet onderzocht geval niet geldt.

Is inductie een onbruikbare brug van het bijzondere naar het algemene? Verre van dat. De brug van de inductie wordt enerzijds begaanbaar geacht, zolang de generaliseringen die door inductie worden verkregen, niet tot onomstotelijke waarheden worden verheven. Inductie is anderzijds ook van vitaal belang, omdat die stap ten grondslag ligt aan creatieve, onverwachte generaliseringen, die nieuwe inzichten met zich meebrengen. In de praktijk zal dus toch geprobeerd worden om de stap te maken van een reeks $(6)(\mathrm{d})$-achtige beweringen naar $(6)(\mathrm{a})$, maar met een slag om de arm. De kennis die we daarmee geproduceerd hebben, is er opnieuw een van de soort 'toegenomen zekerheid', maar zekerheid met een voorbehoud.

De totale opbrengst van de redenering (6) en het onderzoek dat daaraan ten grondslag lag, bestaat dus uit enkele trivialiteiten en de toegenomen zekerheid omtrent enkele vermoedens. Wat begon als vermoedens, als ideeën, eindigt als vermoedens die met wat grotere zekerheid kunnen worden uitgesproken, en wel omdat we in de werkelijkheid (in de trivialiteiten) steun hebben gevonden voor de vermoedens. Dat is het (voorlopige) resultaat van wetenschappelijk onderzoek. Voorlopig, omdat (6) (a) zelf ook weer kan passen in een redenering omtrent 'taalkennis' in een algemenere zin, etc. etc.

Zoals gezegd neemt men in de praktijk inductieve stappen gewoon alsof er niets aan de hand is. En dat is maar goed ook, want alleen zo kan de zgn. hypothetisch-deductieve werkwijze worden gevolgd die bij zoveel wetenschappen favoriet is. Met de term 'hypothetisch-deductieve werkwijze' bedoelen we niets anders dan dat veel wetenschappen op basis van een aantal waarnemingen een hypothese opstellen, die zegt wat in-het-algemeen het geval is; en dat uit die hypothese nieuwe beweringen worden afgeleid die aan de werkelijkheid kunnen worden getoetst.

Eigenlijk gebruiken we in de praktijk een afgezwakte vorm van inductie. Onze generalisatie is eigenlijk een waarschijnlijkheidsbewering. Als we twee keer vers brood bij een bakker hebben gehaald, verleidt ons dat tot de gedachtesprong: de kans is groot dat het brood van die bakker altijd lekker vers is. Zo'n redeneerstap wordt abductie genoemd. Het is de stap die ons brengt van een aantal gevallen waarin $\mathrm{X}$ waar is, naar de waarschijnlijkheid dat X altijd waar is.

Abductie treedt vaak op als mensen van een aantal observaties in de werkelijkheid willen komen tot het vermoeden dat er een regelmaat in schuilt. 
geschiedvorsing vs. geschiedschrijving

geschiedvorsing
Wetenschappelijke verhandelingen zien er nooit uit als opsommingen van beweringen, verbonden door logische connectieven. De redeneringen die er de ruggengraat van uitmaken, zijn altijd opgenomen in een tekst. Ze zijn altijd verpakt. Dat is zelden een probleem, als de redenering of de conclusie waar het eigenlijk om gaat, maar goed zichtbaar blijft. Er zijn evenwel wetenschapsgebieden waarin de tekst meer is dan een verpakking van een wetenschappelijke redenering. Men moet hier in de eerste plaats aan de geschiedenis denken.

Om toe te lichten wat er in de producten van historisch onderzoek aan de hand is, maken we allereerst een onderscheid tussen geschiedvorsing en geschiedschrijving.

Geschiedvorsing richt zich op het ordenen en structureren van reeksen gegevens die betrekking hebben op een of meer facetten van het verleden. Het 'houdt zich bezig met het vaststellen van wat er precies gebeurd is, met de oorzakelijke verklaring van wat er precies gebeurd is etc.' (Ankersmit 1981: 280)

[...] their concern is to establish how cities or convents acquired legal or feudal rights, how historical monuments came to be erected, how diplomatic treatises came into being, they study the changes in the price of bread or the growth and the decline in the population of different areas. (Ankersmit 1981: 8)

Als geschiedvorsers lijken historici soms op sociale wetenschappers, maar dan voor gebeurtenissen uit het verleden. Het onderzoek van Fogel en Engerman dat in het volgende hoofdstuk aan de orde komt, is een goed voorbeeld van geschiedvorsing. Maar daarnaast is er de geschiedschrijving, die vorm van geschiedbeoefening waarin de gevonden feiten tot een verhaal worden aaneengesmeed.

Their concern is not so much with the facts themselves or even with their correct interpretation as with the question what might be the most acceptable representation or synopsis of parts of the past. (ibidem 8-9)

Kenmerkend voor de geschiedschrijver is dat de onderzoeker alleen gebruik maakt van die feiten die onder een bepaald oogpunt relevant zijn, en die aan een gekozen standpunt relevantie verlenen. Het standpunt rechtvaardigt als het ware de selectie van de feiten. Een geschiedschrijver mag wel feiten verzwijgen: er zijn gewoon te veel feiten om er allemaal recht aan te doen. Maar er mogen geen historische feiten verdonkere- 
het product van

geschiedschrijving is

een tekst

wetenschappelijke status van een tekst

een kwaliteit van

teksten is

'samenhang'

temporele

samenhang

causale samenhang en common sense maand zijn die onder het gekozen gezichtspunt niet congrueren met het gekozen perspectief.

De geschiedschrijvers onder de historici produceren 'verhalen'. En een verhaal is meer dan een redenering, of een conclusie uit een redenering, of een oplossing van een probleem of toegenomen zekerheid omtrent een in een bewering vervat vermoeden. Het product van het onderzoek is een tekst, waarvan de kwaliteit niet kan worden gereduceerd tot de geldigheid van de redeneringen en de waarheid van de beweringen die er deel van uitmaken.

De wetenschappelijke status van teksten is niet zonder meer duidelijk. Ze kunnen niet waar of onwaar worden genoemd, want waarheid en onwaarheid zijn eigenschappen van beweringen. Natuurlijk, omdat een tekst bestaat uit beweringen, kan een tekst op de waarheid of onwaarheid van de beweringen worden getoetst. En wat dat betreft, moet een historisch verhaal uiteraard in orde zijn. Maar een tekst is meer dan dat. Teksten kunnen ook niet zoals redeneringen geldig of ongeldig heten. $\mathrm{Al}$ moeten de in een tekst gebruikte redeneringen geldig zijn, we kunnen de kwaliteit van een tekst niet reduceren tot de kwaliteit van de redeneringen.

Wat maakt een tekst dan tot een goede tekst? Een exclusieve kwaliteit van teksten is samenhang. Wat maakt dat een tekst samenhang vertoont, wordt bestudeerd in de tekstwetenschap, een onderdeel van de taalkunde. Van de vele factoren die een bijdrage leveren aan de samenhang in de tekst, noemen we er twee die in het bijzonder gelden voor teksten als producten van geschiedschrijving. Een tekst heeft samenhang als delen ervan die over een-en-dezelfde zaak gaan, temporeel geordend zijn. 'Jan deed dit, en daarna deed hij dat.' Ook is er samenhang als de delen een causale ordening vertonen. 'Jan deed zus, omdat Piet zo deed.' De temporele of causale relaties in een tekst behoeven niet expliciet te zijn verwoord met woorden als nadat, toen, veroorzaken dat, maken dat, omdat, door etc. De relaties kunnen ook impliciet blijven.

Dat temporele relaties een rol spelen in een geschiedverhaal behoeft geen betoog. Het gaat in de geschiedenis nu eenmaal vaak over gebeurtenissen die in de tijd op elkaar volgen, en over veranderingen en ontwikkelingen.

Als twee gebeurtenissen in de tijd elkaar opvolgen, is de waarnemer ervan soms geneigd een causale samenhang tussen die twee gebeurtenissen aan te nemen. Hij denkt dat de tweede gebeurtenis door de eerste is veroorzaakt. De lezer is bereid een causale samenhang tussen twee feiten te construeren, als hij een beroep kan doen op common sense. Het gezond verstand vult de singuliere beweringen (a) en (b) aan met de algemene regel (c). 
minimale

voorwaarden voor de wetenschappelijkheid van een tekst

is samenhang een exclusieve eigenschap van historische teksten?

moet kennis mooi worden opgeschreven? (a) 1549 kende een koud voorjaar;

(b) in 1549 mislukte de graanoogst;

(c) een koud voorjaar doet de graanoogst altijd mislukken.

In deze algemene regel, die voor de lezer common sense is, is de causale relatie aanwezig. (b) is het gevolg van (a) omdat (c). Dat de historicus gebruik maakt van common sense hebben we al eerder opgemerkt. Merk op dat de historici er niet in geïnteresseerd zijn om dit soort algemene regels 'waar' te maken; ze willen ons deelgenoot maken van hetgeen er in 1549 gebeurde. En om tussen twee gebeurtenissen in dat jaar een relatie te construeren, doen ze een beroep op een reservoir van common sense. Over samenhang als maat van succes in alfavakken zullen we uitvoeriger spreken in hoofdstuk 6.

Een geschiedschrijver zal dus succes oogsten met een verhaal als minimaal aan de volgende voorwaarden is voldaan:

- er moet tussen de beschreven feiten een samenhang zijn aangebracht;

- voorzover in het geschiedverhaal een beroep gedaan wordt op common sense moet de lezer bereid zijn deze common sense te beamen;

- de selectie van de beschreven feiten moet gerechtvaardigd kunnen worden vanuit het perspectief dat de schrijver heeft gekozen;

- er mogen geen bekende feiten buiten de beschrijving blijven die strijdig zijn met elementen uit de tekst.

Wat hier exclusief voor de geschiedschrijving werd beschreven, heeft ook relevantie voor teksten in andere wetenschapsgebieden. In de meeste wetenschapsgebieden wordt in teksten een samenhang geconstrueerd tussen theorieën, feiten en redeneringen. Zoals we in hoofdstuk 6 zullen zien is de rechtvaardiging van theorieën gebaat bij de constructie van een samenhang, die op dezelfde eigenschappen kan worden beoordeeld als het verhaal als product van de geschiedschrijving. Temporele, niet causale relaties spelen in niet-historische wetenschappelijke teksten doorgaans geen grote rol.

Tot slot nog dit. Er is een tijd geweest waarin velen in de alfavakken hun producten ook een esthetische waarde toeschreven. Het werk van de historicus Huizinga is daar een goed voorbeeld van. Hij meende dat het esthetische een wezenlijk bestanddeel was van het historische beeld dat een historicus schetst. Maar hij gaf wel toe dat ook historische teksten de waarheid niet dichter benaderen als ze mooi zijn. Rationaliteit bleef ook voor Huizinga het hoogste doel. (Huizinga 1905)

Voor de lezer kan het natuurlijk een aantrekkelijke bijkomstigheid zijn dat een wetenschappelijke tekst niet alleen beantwoordt aan de eisen van de rationaliteit, maar ook 'leesbaar' is, d.w.z. beantwoordt aan het 


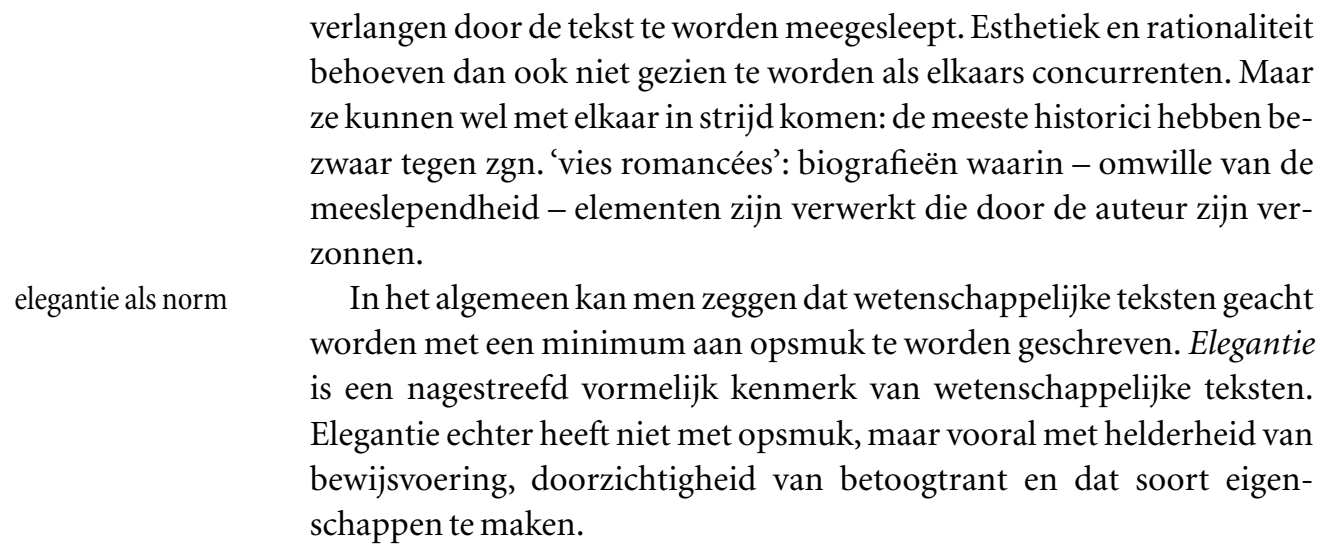


4

empirische wetenschappen

de geschiedbeoe-

fening een

empirische wetenschap?

\section{De wetenschapper en de werkelijkheid}

De wetenschappen worden doorgaans verdeeld in empirische en nietempirische wetenschappen.

Empirische wetenschappen doen beweringen die betrekking hebben op de waarneembare werkelijkheid, of beweringen waar beweringen uit kunnen worden afgeleid die betrekking hebben op de waarneembare werkelijkheid. De taalkunde, de economie, de natuurkunde, de geografie, de chemie: het zijn allemaal disciplines die uitspraken doen over de waarneembare werkelijkheid.

Niet-empirische wetenschappen doen dat niet. De wiskunde en de logica bijvoorbeeld zijn vakken die uitgaan van een aantal als waar aanvaarde stellingen. Die worden axioma's genoemd. Uit de axioma's worden deductief nieuwe beweringen afgeleid. Van een willekeurige bewering in de wiskundige of logische taal wordt aangetoond dat deze 'waar' is, dat wil zeggen te herleiden is tot een of meer van de axiomatisch ware beweringen. De beweringen hoeven geen betrekking te hebben op de werkelijkheid.

Soms worden ook empirische wetenschappen wel axiomatisch opgezet. Beweringen, afgeleid uit de axioma's, kunnen bij de empirische wetenschappen aan de werkelijkheid worden getoetst. Voorzover bekend, is in de geesteswetenschappen een dergelijke axiomatische verankering alleen enigszins reçu bij formeel-grammaticale theorieën. Maar ook zonder een dergelijke axiomatisering heet een wetenschap empirisch, als de beweringen ervan betrekking hebben op de (waarneembare) werkelijkheid. In deze zin zijn de meeste alfavakken empirische wetenschappen.

Geldt dit ook voor de historische vakken? Doen historici uitspraken over de waarneembare werkelijkheid? Of uitspraken waar uitspraken over de waarneembare werkelijkheid uit kunnen worden afgeleid? We kunnen het er gemakkelijk over eens zijn dat het verleden zelf niet meer waarneembaar is. De moord op Willem van Oranje kunnen we niet meer waarnemen. En niemand heeft in het begin van het derde millennium ooit een dinosauriër gezien. Desondanks is het voor iemand met een realistische visie op de werkelijkheid zeker dat er uitspraken over die moord en over dinosauriërs gedaan kunnen worden, en dat waarnemingen in de werkelijkheid de zekerheid kunnen doen toenemen van uitspraken over Willem van Oranjes levenseinde of over dinosauriërs. We 
het waarneembare deel van de werkelijkheid groeit

voorbeelden van nieuwe waarnemingstechnieken in de humaniora kunnen namelijk in de werkelijkheid waarnemingen doen die we in verband kunnen brengen met Willem van Oranje en dinosauriërs: er zijn bronnen of sporen overgebleven. Daaruit blijkt dat onze kennis over het verleden een grondslag heeft in de waarneembare werkelijkheid. Dat wat er uit het verleden bewaard is gebleven: brieven, akten, en andere archiefstukken, maar ook gebouwen en voorwerpen; botresten, fossiele afdrukken, dat maakt de geschiedenis (en de paleontologie) tot een empirische wetenschap.

Gegevens uit de waarneembare werkelijkheid, ook observaties genaamd, geven aan wetenschappers de mogelijkheid uitspraken aan de werkelijkheid te toetsen. Vandaar dat onderzoekers er veel werk van maken gegevens te verzamelen, observaties te doen. Vandaar ook dat er steeds nieuwe waarnemingsmiddelen en -instrumenten worden ontwikkeld en beproefd. Wat er waarneembaar is in de werkelijkheid, verandert daardoor. Door de beschikbaarheid van een zeer groot arsenaal van waarnemingswerktuigen kunnen we tegenwoordig veel meer zien dan vroeger. Gemakkelijk is in te zien dat dat zeker ook voor de geesteswetenschappen het geval is.

Enkele voorbeelden. De analyse van kunstvoorwerpen heeft al lang en ruimschoots kunnen profiteren van de fotografie. Kunstvoorwerpen behoeven niet meer in elkaars nabijheid te worden gebracht om ze toch met elkaar te kunnen vergelijken. De afgelopen decennia zijn nog veel andere analytische technieken in het kunsthistorisch onderzoek gemeengoed geworden. Het gebruik van gammastraling maakt onderliggende lagen verf zichtbaar. Scheikundige technieken maken een analyse van de gebruikte verf mogelijk. Het tellen en analyseren van de jaarringen in hout, een techniek die bekend staat als de dendrochronologie, maakt datering van een houten paneel mogelijk, etc.

De analyse van spraak door fonetici kan zeer veel verfijnder zijn dan vroeger, omdat spraakgeluid nu op geluidsdragers opgenomen en gereproduceerd, maar ook zichtbaar gemaakt kan worden, op een analytischer manier dan met letters, of de letterachtige tekens van een fonetisch schrift.

Iets dergelijks geldt voor de musicologie, waar onderzoekers geprofiteerd hebben van technieken voor reproductie en analyse van geluid, zoals de grammofoonplaat en de bandrecorder. Ook is het mogelijk gebleken met de computer passende melodieën terug te vinden voor liederen die slechts als tekst zijn overgeleverd.

In de historische wetenschap zijn de waarnemingstechnieken eveneens door de automatisering verbeterd. Sommige archieven zijn of worden gecomputeriseerd, zodat ze sneller doorzocht kunnen worden. Daarnaast maakt computeranalyse van vroege watermerken datering van documenten beter mogelijk dan vroeger. 
het overzienbare deel van de werkelijkheid groeit

computers zijn in de humaniora meer 'zoekmachines' dan 'rekenmachines'

voorbeelden van nieuwe zoektechnieken in de humaniora
Alle vakken zijn door deze technische ontwikkelingen in meer of mindere mate van karakter veranderd. Het aantal gegevens dat onder meer door de nieuwe waarnemingstechnieken beschikbaar komt, neemt snel toe. Dat geldt voor de precisie van de waarnemingen en voor de betrouwbaarheid van de uitspraken die op die waarnemingen zijn gebaseerd.

Speciaal ook computers spelen in deze ontwikkeling een grote rol, niet omdat ze sneller kunnen rekenen, maar omdat ze sneller kunnen zoeken. Door de beschikbaarheid van computers nemen de mogelijkheden toe om grote aantallen gegevens te ordenen, om ze overzichtelijk te maken, en met elkaar in verband te brengen. De toepassing van de nieuwe zoekmogelijkheden van de automatisering zal ongetwijfeld in de toekomst tot verdere veranderingen in het onderzoek in de humaniora leiden.

Opnieuw een paar voorbeelden. In de kunstgeschiedenis worden veelbelovende resultaten geboekt met de opslag en de analyse van beeldmateriaal. Dit zal in de toekomst vergelijking van grote hoeveelheden afbeeldingen mogelijk maken. Als men nu afbeeldingen bij elkaar moet zoeken van - om maar wat te noemen - pygmeeën die door vogels in hun kuit worden gepikt, moet men werken met grote hoeveelheden foto's en een beperkt aantal indexen van namen van afgebeelde figuren. Dat levert meestal aparte verzamelingen van afbeeldingen van pygmeeën en van vogels op, maar niet de doorsnede van die verzamelingen: de afbeeldingen waar ze allebei op te zien zijn. Met de computer kan dat in principe wel. Aan het op deze wijze toegankelijk maken van allerlei verzamelingen afbeeldingen wordt op het ogenblik gewerkt.

In de taalkunde worden de laatste jaren grote taalcorpora aangelegd, grote verzamelingen taalmateriaal die via de computer beschikbaar zijn voor allerlei soorten taalanalyses. Dit materiaal is 'verrijkt', dat wil zeggen dat er taalkundige informatie aan de woorddelen, woorden en woordgroepen is toegevoegd. Dit biedt de mogelijkheid snel naar het voorkomen van alle mogelijke woorden en zinsconstructies te zoeken. (Cf. Van Oostendorp en Van der Woude 1998) Gespecialiseerde corpora van letterkundige teksten zijn eveneens voor allerlei nieuw letterkundig onderzoek beschikbaar. (Cf. Mourits en Vaessens 1997) Nu is het nog niet mogelijk om snel aan de weet te komen of er een Middelnederlands gedicht of lied bestaat dat met de woorden 'Het steit een boem' (Er staat een boom) begint, maar een geautomatiseerd repertorium zal dat in de toekomst wel mogelijk maken. (Gerritsen 1997)

Jaargangen van (oude) kranten verschijnen op cd-rom. Deze digitalisering van kranten zal ook een krachtig hulpmiddel blijken voor het (contemporain) historisch onderzoek.

Soms scheppen wetenschappers hun eigen werkelijkheid. Dat is het geval als zij de werkelijkheid zo manipuleren, dat een gebeurtenis waar 
observaties van een gemanipuleerde werkelijkheid: experimenten

de anti-psychologistische attitude van de wetenschap men in de niet gemanipuleerde werkelijkheid eindeloos op zou hebben moeten wachten, zich onder gecontroleerde omstandigheden gaat voordoen. De onderzoeker experimenteert. Als gevolg van menselijk ingrijpen toont de werkelijkheid zich in een experimentele situatie op een manier die de onderzoeker nodig heeft. De onderzoeker isoleert in een experiment op kunstmatige wijze een stukje van de werkelijkheid, opdat dit stukje van de werkelijkheid beter kan worden waargenomen. Enquêtes, waarin proefpersonen worden ondervraagd, zijn ook op te vatten als een vorm van experiment. De proefpersonen worden geacht antwoorden te geven die in de gewone werkelijkheid ook te vinden zullen zijn, maar niet zo dat een onderzoeker er getuige van is. Empirische wetenschappen waarin experimenten (een deel van) de observaties leveren, heten experimentele wetenschappen. Sommige wetenschappen zijn compleet experimenteel, dat wil zeggen dat er geen observaties worden gebruikt die in 'het vrije veld' zijn gedaan. Voor alle onderzoek in die vakgebieden moeten derhalve experimenten worden opgezet.

Onderzoekers beogen de werkelijkheid te beschrijven zonder dat de persoon van de onderzoeker (in filosofische termen: het kennend subject) in beeld komt. Psychologische factoren, persoonlijke karaktertrekken of privé-opvattingen van de onderzoekers mogen geen rol spelen. De wetenschap probeert, zoals dat heet, psychologismen buiten te sluiten. De wetenschap kent vrij algemeen een anti-psychologistische attitude. We zullen in deze paragraaf zien welke maatregelen de geesteswetenschappers nemen om dit doel te bereiken; en op welke punten ze in principe noodzakelijk falen; en welk praktisch standpunt ze innemen om het anti-psychologistische standpunt toch recht te doen.

In dit hoofdstuk gaan we nader in op de relatie tussen de wetenschapper en de werkelijkheid. In paragraaf 4.1. onderzoeken we de werkelijkheid als object van waarneming. In paragraaf 4.2. richten we ons op de waarnemer zelf.

In deze paragraaf zullen we bezien welke elementen uit de werkelijkheid de geesteswetenschapper gebruikt, en hoe de onderzoeker de werkelijkheid manipuleert. Daarmee verschaffen we een fundament voor nadere beschouwingen over waarnemen, interpretatie en het verwoorden van waarnemingen in paragraaf 4.2 .

gegevens De indeling van de vakgebieden is in de eerste plaats gebaseerd op een indeling van de werkelijkheid. Het spreekt daarom vanzelf dat het in de eerste plaats afhangt van het vakgebied wat de wetenschappers als gegevens beschouwen. 
gegevens in verschillende vakken: de kunstgeschiedenis

gegevens in verschillende vakken: andere kunstvakken

gegevens in verschillende vakken: literatuurwetenschap

complicaties

'kwaliteit' bepaalt wat als primair gegeven telt
Voor de kunsthistoricus worden de gegevens primair geleverd door schilderijen, tekeningen, prenten, grafische producten van allerlei soorten technieken, beeldhouwwerken, plastieken en gebouwen; en resten van die zaken, onderdelen en details tot en met de streek-van-een-kwast. Daarbij gaat het zowel om die dingen in hun materiële vorm, de chemische analyse van het materiaal bijvoorbeeld, als om de 'voorstellingen', als daarvan gesproken kan worden, en aspecten daarvan zoals de stijl en het genre.

Ook voor de wetenschappers die zich met andere kunstvormen bezighouden leveren de kunstwerken van hun vakgebied de primaire observaties. Voor de musicoloog zijn het vaker de geschreven notenbeelden, de partituren, dan de uitvoeringen. Voor de theaterwetenschapper daarentegen vormen juist 'voorstellingen' de primaire gegevens; en niet in de eerste plaats de toneelteksten. De tekst is niet meer dan een onderdeel van de voorstelling. En los van de voorstelling rekent de theaterwetenschapper een toneeltekst eerder tot het vakgebied van de letterkunde dan tot zijn eigen vakgebied. De letterkundigen ontlenen in hun rol van kunstbeschouwers hun primaire observaties aan teksten, en wel teksten die op enigerlei wijze als 'literair' te boek staan. Fictionele teksten en teksten met poëtische kenmerken (rijm, metrum, strofebouw) maken daar een groot deel van uit.

De vraag wat in de kunstwetenschappen als gegeven geldt, is in de praktijk echter heel wat ingewikkelder. Twee dingen zorgen daarvoor. Ten eerste speelt 'kwaliteit' een rol bij het bepalen van de objecten die voor bestudering in aanmerking komen. Dit geldt zowel voor de literaire als de niet-literaire kunstwetenschappen. De werken die op een bepaald moment door 'mensen met een ontwikkelde smaak', door critici, door een culturele elite, door de onderzoekers zelf van hoge kwaliteit worden geacht, vormen samen de 'canon' van een kunstdiscipline. Die canon is aan verandering onderhevig. Wat niet van de canon deel uitmaakt (werk van mindere schrijvers en kunstenaars, maar ook genres als stripverhalen, popmuziek, graffiti etc.) vraagt meestal als onderzoeksobject een extra rechtvaardiging.

Merk op dat ook de studie van die minder hoog aangeschreven genres onvermijdelijk beheerst wordt door de canons die binnen ieder van die werkelijkheidsgebieden bestaan. Net als voor de letterkundige niet ieder gedicht een interessant onderzoeksobject is, zal ook niet ieder getekend verhaal met tekst of tekstballonnen voor onderzoek in aanmerking komen.

Het bestaan van een canon - hoe die ook tot stand is gekomen - betekent dat het voor sommige onderzoeksvragen niet vaststaat op welk deel van de werkelijkheid de antwoorden eigenlijk betrekking zullen hebben. Dit geldt bijvoorbeeld voor alle onderzoek dat een historisch overzicht 
het kunstwerk als autonoom onderzoeksobject vs. het kunstwerk als deel van het culturele systeem

geschiedenis

bronnenkritiek

directe en indirecte bronnen probeert te geven. Het maakt nogal wat uit of men in een geschiedenis van de muziekbeoefening in Nederland in de jaren zestig van de twintigste eeuw de popmuziek betrekt of niet, en/of de huismuziek en/of de amateuristische muziekbeoefening in bands, fanfarekorpsen en harmoniekapellen. Men mag aannemen dat bij de onvermijdelijke selectie allerlei prototypieën van de onderzoeker een rol spelen.

Het tweede dat de vraag naar de te bestuderen werkelijkheid in de kunstwetenschappen compliceert, is de omstandigheid dat de kunstwerken niet noodzakelijk als autonome, op zichzelf staande objecten behoeven te worden gezien. Ze hebben een geschiedenis van zichzelf. Er is een maker of een maakster, er is een ontstaansgeschiedenis, er is een cultureel en politiek klimaat waarin het werk ontstaat en moet zien te gedijen, er is een publiek dat het werk 'recipieert', er zijn critici, er zijn andere kunstenaars die er met hun werk op reageren. Het kunstwerk maakt, om kort te gaan, deel uit van een cultureel systeem. En kennis van het culturele systeem kan net zo goed tot de kennis van het kunstwerk behoren als de analyse van het kunstwerk zelf. Alle aspecten van het culturele systeem kunnen vroeg of laat in aanmerking komen voor onderzoek.

In de geschiedenis van de kunstvakken, vooral van de literatuurwetenschap, zijn de vragen met betrekking tot het object van onderzoek doorlopend onderwerp van debat. (Laan 1997)

De observaties van de historicus betreffen de materiële dingen die uit het verleden zijn overgebleven: huizen, ruïnes, meubilair, potscherven, munten, en natuurlijk vooral de tekst op 'beschreven papier': brieven, ambtelijke stukken, documenten, kranten en boeken. Die dingen worden doorgaans kortweg 'de bronnen' genoemd. Dat is het wat er resteert van het verleden. Daarnaast zijn er voor het recente verleden ook foto's, films en video-opnames waaraan observaties kunnen worden ontleend. Een belangrijk punt voor de historicus is de vraag naar de afstand tussen de bron en de historische werkelijkheid. In welke bron is het gegeven aangetroffen? Is de bron de enige? De oudste? Zijn er redenen om aan te nemen dat de bron vervalst is, of dat de feiten bewust zijn verdraaid? Wat was de relatie tussen de auteur van de bron en de historische gebeurtenis waar de bron betrekking op heeft? Was de auteur ooggetuige of niet? Deelt de auteur mee waar hij/zij zich op baseert? etc. Een hele reeks van factoren kunnen bepalend zijn voor de afstand tussen de historische werkelijkheid en de empirische gegevens die er over beschikbaar zijn. Het proces van het keuren van de bron op betrouwbaarheid noemen we bronnenkritiek.

Historici maken soms een onderscheid tussen directe en indirecte bronnen. Een directe bron is een verslag van een historische gebeurtenis door iemand die zelf getuige is geweest van de gebeurtenis; een indirecte bron is een beschrijving of een vermelding van een gebeurtenis door iemand die er niet zelf getuige van is geweest. 
directe bronnen altijd de beste?

bestaat er in de geschiedbeoefening een canon?

taalkunde

grammaticaliteitsoordelen; intuïties over de correctheid van een taalvorm

taalgebruiksgevallen

proefpersonen wordt taalgebruik ontlokt
Het is overigens zeker niet zo dat directe bronnen altijd beter zijn dan de indirecte. Er bestaan legio voorbeelden waar de indirecte bronnen betrouwbaarder geacht moeten worden dan de directe.

Hoewel de geschiedbeoefening zich al lang niet meer beperkt tot de geschiedenis van oorlogen en 'grote mannen', lijkt er in de praktijk van het historisch onderzoek toch ook een canon te bestaan van onbetwistbaar belangrijke historische personen, gebeurtenissen en verschijnselen, die richtinggevend is bij de selectie van de primaire historische gegevens. Dat kan worden opgemaakt uit de soms heftige discussies rond de al of niet vermeende eenzijdigheid van het historisch onderzoek, waarin weinig plaats zou zijn voor vrouwen, het leven van alledag, het platteland, etc. Ook voor deze gebieden geldt echter dat thema- en onderwerpskeuze bepaald wordt door de canons die binnen die gebieden gelden. Er bestaat eenvoudigweg niet zoiets als de 'studie van alles'. In alle wetenschappen is de keuze van de observaties ondergeschikt aan de belangwekkendheid van de analyse of de theorie die de opbrengst van het onderzoek is.

De taalkunde maakt, al naar gelang het soort onderzoek, gebruik van een of meer van de volgende drie soorten gegevens.

(a) De taalkundige zet iets in elkaar dat er uit ziet als een woord, een klankenreeks, een zin, een woordgroep; en beoordeelt of dit taalbouwsel als een woord, een klankenreeks, een zin, of een woordgroep van de moedertaal kan gelden. Het intuïtieve oordeel 'grammaticaal' of 'ongrammaticaal' over zo'n geconstrueerde talige vorm is een primair gegeven. Zo kan de taalkundige in analogie van het woordpaar keten/ketentjes het woordpaar hersenen/hersenentjes vormen; en vervolgens als oordeel geven dat hersenen een goed Nederlands woord is, maar ${ }^{\star}$ hersenentjes niet. De laatste vorm is ongrammaticaal, zegt men.

(b) De taalkundige beschouwt ook dikwijls willekeurige gevallen van taalgebruik als een primair gegeven. Hij of zij stelt bijvoorbeeld vast dat de vorm een stuk of vijf, zes in het Nederlands voorkomt, en niet de vorm een stuk of vijf, zeven. Een computer helpt grote taalcorpora te analyseren om dit vast te stellen. 'Taalgebruiksgevallen' leveren de primaire observaties in veel takken van de taalwetenschap: sociolinguïsten, communicatiekundigen, tekstwetenschappers, vertaalkundigen, lexicografen ('woordenboekenmakers') werken bij voorkeur met taal die 'echt', in natura is aangetroffen.

(c) De taalkundige maakt een proefopstelling in een soort laboratorium en probeert aan proefpersonen een reactie te ontlokken:'zou u deze tekst willen voorlezen'; 'probeert $\mathrm{u}$ eens te beschrijven wat $\mathrm{u}$ ziet'; ' $u$ krijgt zo een geluid te horen; zou u op knop A willen drukken als u denkt dat het geluid een $[t]$ is.' 


\section{Voorbeelden van taalkundige intuïties}

De generatief-taalkundige gebruikt intuïties over (meestal zelf verzonnen) zinnen als empirisch materiaal. Een paar voorbeelden. Waar --- staan, is het werkwoord zag weggelaten. Het verschijnsel wordt 'gapping' genoemd. Een asterisk ${ }^{*}$ ) wil zeggen dat de zin geen zin van het Nederlands is.

(1a) Jan zag Marie en Kees --- Mies.

(1b) Ik denk dat Jan Marie zag en Kees Mies ---.

(2a) ${ }^{\star}$ Ik denk dat Jan Marie zag en Kees de man die Mies ---.

(2b) ${ }^{\star}$ Ik denk dat Jan Marie zag en wist waar Kees Mies ---.

(2c) ${ }^{\star}$ Ik denk dat Jan Marie zag voor Kees Mies ---.

De zinnen (1) laten zien dat een werkwoordsvorm als zag in sommige Nederlandse zinnen kan worden weggelaten. De zinnen (2) laten zien dat het niet altijd kan. Aangenomen wordt dat er in de zinnen (1) een relatie kan worden gelegd tussen het aanwezige zag, en de plaats waar het weggelaten zag zou hebben gestaan. In de zinnen (2) verhindert een eigenschap van de zinsstructuur dat er zo'n verbinding wordt gemaakt. Die eigenschap verklaart hun ongrammaticaliteit. De taalkundige zoekt naar de meest algemene formulering van deze en soortgelijke relaties in termen van de zinsdelen waaruit de zin is opgebouwd.

Nederlandssprekende lezers kunnen gemakkelijk voor zichzelf vaststellen dat de observaties in (1) en (2) in overeenstemming zijn met hun eigen kennis van het Nederlands. Zij hebben dezelfde intuïties als de taalkundigen.

Bron: Jan Koster, 'Gapping moet blijven', in: Tabu (1998), 28-3

andere soorten gegevens zijn secundair

Primaire taalkundige gegevens zijn dus (a) grammaticaliteitsoordelen, (b) taalgebruiksgevallen en (c) ontlokt taalgebruik. Welke van deze drie soorten gegevens de taalkundige zal gebruiken, hangt af van de onderzoeksvraag.

Gegevens ontleend aan naslagwerken als grammatica's of woordenboeken zijn secundaire gegevens. De aanwezigheid van het woord ontbijtservet in een willekeurig woordenboek betekent zoveel als: een lexicograaf heeft op een of andere manier vastgesteld dat het woord ontbijtservet door Nederlanders (in verschillende omstandigheden) gebruikt wordt als een gewoon woord van de Nederlandse taal. De aanwezigheid 
zijn taalkundige intuïties niet strijdig met de anti-psychologistische attitude van de wetenschap?

vooruitblik van het woord ontbijtservet in het woordenboek is een secundair gegeven gebaseerd op het primaire gegeven dat dit woord in het feitelijk gebruik is aangetroffen.

Ook kunnen de oordelen van taalkundigen en niet-taalkundigen over het taalgebruik van anderen als secundaire gegevens gelden. 'Ik vind dat dialect op de preekstoel niet kan.' Er komen in advertentieteksten te veel Engelse woorden voor.' Dit soort oordelen is vaak normatief van aard. Dit wil zeggen dat die oordelen vaak betrekking hebben op de vraag of de vormen in overeenstemming zijn met hoe het in een taal eigenlijk hoort.

De taalkundigen die gebruik maken van hun intuïties bij grammaticaliteitsoordelen is vaak verweten dat zij iets doen dat in de wetenschap vermeden moet worden, namelijk varen op het kompas van hun (subjectieve) inzichten. Taalkundigen betogen echter op goede gronden dat die oordelen een vorm van waarneming zijn, en - zoals we nog zullen zien kan waarneming zich niet onttrekken aan de eigenaardigheden van de menselijke geest. (Kerstens en Sturm 1989)

Was het nu maar zo dat de te onderzoeken werkelijkheid kant en klaar voor onderzoek gereed lag. Maar dat is niet het geval. Om de waarneming van de werkelijkheid succesvol te laten verlopen, moet de werkelijkheid soms op een aantal verschillende manieren gemanipuleerd worden. In de volgende subparagrafen bespreken we verschillende vormen van manipulatie. Achtereenvolgens kijken we naar

- procedures om stukjes van de werkelijkheid te isoleren en als het ware onder een vergrootglas te bekijken; paragraaf 4.1.1.

- procedures om een groot aantal stukjes van de werkelijkheid kwantitatief te manipuleren; paragraaf 4.1.2.

- procedures om een deel van de werkelijkheid voor onderzoek af te bakenen; paragraaf 4.1.3.

4.1 .1

Manipulatie van de werkelijkheid 1: isolatie en uitvergroting

'stukjes'van de werkelijkheid
Op het eerste gezicht lijkt het zo te zijn dat de waarnemingen preciezer kunnen zijn, naarmate de 'stukjes' van de werkelijkheid kleiner zijn. De gedragswetenschappen bijvoorbeeld hebben zich veel moeite getroost methodes te ontwikkelen waarin de gedragswerkelijkheid is gereduceerd tot het 'gedrag' van een druk-op-de-knop van een proefpersoon als reactie op een bepaalde vraag in een experiment. Anderen reduceren het gedrag tot het zwart maken van een hokje in een enquête. Heel veel kleiner kan de eenheid van gedrag niet zijn. Waarom is dat eigenlijk? Wat is de reden dat onderzoekers op zo'n onnatuurlijke manier naar de werkelijkheid kijken? Voordat we op die vraag in algemene zin ingaan, kijken we eerst nog wat preciezer naar de praktijk. 
de fonetiek als voorbeeld

reacties van proefpersonen

waarom 'kleine stukjes'?

geringe interpretatieruimte en kwantificeerbaarheid
De fonetiek is een onderdeel van de taalkunde. Het is de studie van het spraakgeluid. En aangezien spreken een vorm van gedrag is kan men de foneticus zien als een gedragsonderzoeker. De foneticus beperkt zich daarbij veelal tot de fysieke aspecten van het gedrag: hij of zij bemoeit zich niet met de bedoelingen die taalgebruikers met het gedrag zouden kunnen hebben. Men zoekt er het antwoord op vragen als: wat maakt het eigenlijk mogelijk dat je aan mensen kunt horen dat ze jouw taal spreken, terwijl hun stemmen toch ook zoveel verschillen dat je ze aan hun stem kunt herkennen? Hoe kan langs elektronische weg met een klankgenerator spraakgeluid worden nagemaakt? Hoe kan ik er vervolgens voor zorgen dat de automatenstem Nederlands klinkt en geen Engelse stembuigingen produceert? Hoe komt het dat men aan de stem van een $\mathrm{Ne}$ derlands sprekende Engelsman meestal kan horen wat de moedertaal van de spreker was? Wat bepaalt eigenlijk het verschil tussen een mannen- en een vrouwenstem? etc.

Fonetici doen proeven met spraakgeluid, dat zij aan proefpersonen laten horen. Een voorbeeld. In een afgesloten ruimte bevindt zich een tafeltje waarop een knop is gemonteerd waarmee de toonhoogte van een geluid 'met de hand' hoger en lager kan worden gemaakt. De foneticus laat aan een proefpersoon een heel klein stukje spraaksignaal horen, een stukje spraak van slechts een fractie van een seconde lang, en vraagt de proefpersoon om met de knop aan te geven hoe hoog de toonhoogte is van het beluisterde spraaksignaal. In zo'n situatie geldt als 'elementair feit':

- proefpersoon A zet bij spraaksignaal X de knop op stand P.

Men beschouwt dit enkele antwoord van een enkele proefpersoon op een enkel spraaksignaal als een elementair gegeven. Uiteraard worden deze gegevens geaggregeerd; ze worden door eenvoudige rekenkundige bewerkingen tot statistische samengestelde feiten, zodat ook als feit kan gelden: $75 \%$ van de proefpersonen gaf aan dat ze de hoogte van spraakgeluid $\mathrm{X}$ waarnamen als een toon van tussen de 160 en $165 \mathrm{~Hz}$. Cohen, Collier en 't Hart die in de jaren zestig en zeventig in een baanbrekend onderzoek toonhoogte-contouren van verschillende Nederlandse zinnen opspoorden, werkten met dit soort gegevens. ('t Hart, Collier en Cohen 1990)

Men zoekt hier naar het kleinste stukje werkelijkheid dat nog als relevant taalgedrag kan gelden. Het voordeel van zulke observaties van 'atomen-van-het-gedrag' is dat de observerende onderzoeker weinig ruimte krijgt om een eigen interpretatie aan het gedrag te geven. Dubbelzinnigheid lijkt uitgesloten. In volgende hoofdtukken zullen we nog zien hoe wezenlijk dit is. Alle storende context is uit het stukje van de werkelijkheid verdreven. Een druk op de knop is een druk op de knop, daar kun je 
als waarnemer niet gemakkelijk iets anders van maken. Een effect is ook dat het gedrag van de proefpersoon kwantificeerbaar en statistisch analyseerbaar wordt.

Ook het vaststellen van de stand van een metertje, of het aflezen van een schaal is een observatie die de ruimte voor een interpretatie door de onderzoeker zo gering mogelijk maakt, en die zich laat verwoorden in eenvoudige termen van de omgangstaal. Hoe kleiner de ruimte voor een eigen interpretatie door een onderzoeker, hoe groter de kans dat een tweede onderzoeker hetzelfde zal waarnemen, en hoe groter de kans dat de waarneming ook 'echt' de realiteit en niets dan de realiteit betreft, meent men. Hoe doorzichtiger het observatieproces is, hoe gemakkelijker een ander van een stap in dit proces kan zeggen dat er iets mis mee is. Hoe vatbaarder dit proces is voor kritiek, hoe objectiever. De uitkomsten van het onderzoek: bijvoorbeeld dat $91 \%$ van de proefpersonen op het horen van geluid $[X]$ de knop in stand $\mathrm{P}$ zette, behoeven alsnog een interpretatie. De stap moet worden gemaakt van deze geaggregeerde observaties naar: 91\% van de proefpersonen hoorde een toon van $160 \mathrm{~Hz}$. Met zo'n stap verlaat de onderzoeker het terrein van de beperkte observatie en beziet hij of zij de gegevens in het kader van de veronderstellingen die aan het onderzoek ten grondslag liggen. Dit betekent dat de beoogde $o b$ jectiviteit zich beperkt tot een theoretisch raamwerk. Over het probleem van de objectiviteit van het waarnemen spreken we in hoofdstuk 4.2.1.

\subsection{2}

'kleinste deeltjes' in de (kunst-)geschiedschrijving

de stijlanalyse als voorbeeld

\section{Manipulatie van de werkelijkheid 2: vermenigvuldiging}

In de vorige paragraaf zagen we dat sommige taalkundigen klanken beschouwen als de 'kleinste deeltjes' van spraakgedrag. Het is gemakkelijk in te zien dat niet alle vormen van gedrag of gebeurtenissen op soortgelijke wijze in 'atomen' kunnen worden opgesplitst. Je kunt zo wel - in principe - de verkiezingen voor de Tweede Kamer in stukjes opdelen, maar niet de kabinetsformatie. Je kunt daar misschien fasen in onderscheiden, en andere onderdelen, maar je kunt hem niet onbeperkt in kleinere deeltjes opsplitsen, zonder dat de gebeurtenis zelf ophoudt te bestaan. Gebeurtenissen die in de tijd verlopen, of grotere gedragseenheden die niet in een keer kunnen worden overzien, kunnen niet onbeperkt in kleinere stukjes werkelijkheid worden opgeknipt. Het onderzoek van historische gebeurtenissen, teksten, schilderijen, muziekstukken kan geen gebruik maken van de mogelijkheid het voorwerp van onderzoek 'objectiever' waar te nemen, zoals dat bij de fonetiek in zwang is.

Een van de intrigerendste vragen van de kunstgeschiedenis is de vraag van de stijl. Wat is het dat maakt dat schilderijen globaal gedateerd kunnen worden? Wat maakt dat alle schilderijen van Van Gogh zo herken- 
baar van Van Gogh zijn? Soms staan er bij zulke oordelen grote financiële belangen op het spel. Het komt er dus soms heel erg op aan, hoe kunsthistorici kijken.

Het vergelijken van stilistische kenmerken is een proces dat deels verloopt door middel van beelden in het geheugen, door het opmerken van zeer kleine visuele verschillen, door het waarnemen van 'iets' in een afbeelding dat soms ongrijpbaar lijkt. Deze waarnemingen zijn moeilijk te verwoorden. [...] Deze onverwoordbaarheid maakt de kennersblik oncontroleerbaar, ontoegankelijk, subjectief en dus wetenschappelijk verdacht. (Willems 1993: 125)

Natuurlijk is geprobeerd de stijlanalyse een wetenschappelijke basis te geven. Er is lange tijd gedacht dat men, om aan de verdenking van subjectiviteit te ontkomen, een voorstelling in kleinere eenheden op zou moeten delen. 'Ogen', 'hand', 'haar', 'plooival', 'rotsblok', 'huid', 'deur', 'raam' etc. etc. En die onderdelen zouden op verschillende kunstwerken vergeleken moeten worden. Zo zul je zien: iedere schilder heeft een eigen manier van 'ogen' schilderen, iedere tijd zijn karakteristieke 'plooival'. Men zou willen dat het zo zou werken. Maar nee. Kunsthistorici zijn het er nu wel over eens dat je geen stijl kunt determineren zonder juist te bestuderen hoe de vormelementen tot een voorstelling zijn georganiseerd.

soms leent historisch

materiaal zich voor kwantificatie

cliometrie
Dat neemt niet weg dat ook (kunst-)historisch materiaal zich soms voor kwantificatie leent. We willen dit toelichten aan de hand van een studie van Fogel en Engerman, Time on the cross, over de slavernij in het zuiden van de Verenigde Staten rond het midden van de negentiende eeuw. Het is een beroemd onderzoek. Voor Fogel was het het begin van een carrière als historicus en econoom die recent met een Nobelprijs (voor economie!) werd bekroond.*

De studie van Fogel en Engerman is een voorbeeld van wat wel cliometrie, of 'new economic history' wordt genoemd. De auteurs beogen een nieuwe interpretatie te geven van de op slavernij gebaseerde economie in het zuiden van de Verenigde Staten in de negentiende eeuw. Ze baseren zich daarbij bijna uitsluitend op kwantificeerbare gegevens: aantallen plantages, aantallen slaven, prijs van de slaven, groei van de behoefte aan slaven; levensverwachtingen van slaven en blanken, aantallen huwelijken, aantallen als slaaf geboren kinderen, aantallen als slaaf geboren kinderen waarvan de vader een blanke was, de jaarlijkse onderhoudskosten per slaaf, rentepercentages, opbrengst van arbeid, etc. Al deze zaken zijn

* Zoals bekend bestaat er geen Nobelprijs voor de geesteswetenschappen. De historicus Theodor Mommsen won rond 1900 de Nobelprijs voor de literatuur, zoals ook het historisch werk van Winston Churchill met de Nobelprijs voor de literatuur werd bekroond. 
steeds geaggregeerde gegevens, samengesteld op basis van schattingen en extrapolaties uit beschikbare gegevens in geboorteregisters, beschrijvingen van scheepsladingen, registers van slavenmarkten, jaarrekeningen van plantages etc. Fogel en Engerman vertellen dat er duizenden en duizenden van dit soort gegevens in de archieven te vinden zijn. Hier is een voorbeeld van een van deze soorten gegevens.

Plantation account and record books are on deposit in various historical archives throughout the South. Approximately 4000 observations drawn from 30 plantations in various parts of the South over the entire antebellum era have been recovered from these records and put on tape [zodat ze door een computer kunnen worden verwerkt; T.P]. It is expected that the total number of observations from this source will eventually increase to between 7,00o and 10,000. (Fogel en Engerman 1974: 26-27)

Ieder van de gegevens is een 'stukje werkelijkheid' zoals we dat hiervoor bedoelden, maar samengevoegd tot een statistiek is er een abstracte samenhang tussen deze stukjes gecreëerd. Een geboorte van een kind wordt zo een 'historisch atoom'.

cliometrie als recon-

Het is in de cliometrie alsof de historisch onderzoeker een eeuw na structie van statistieken

kwantificatie brengt toevalsfactor onder controle dato alsnog allerlei gegevens ordent tot overzichten die wij economische, demografische of sociologische statistieken zouden noemen als ze over het heden zouden gaan. De onderzoekers hebben veel feiten nodig om statistisch verantwoorde uitspraken te kunnen doen. De kwantitatieve benadering is gebaseerd op tellen. Tellen kan alleen met gelijksoortige gegevens. De gegevens zijn onder gecontroleerde omstandigheden ontstaan. De instanties die de gegevens bijeenbrachten, hebben vaak aangegeven hoe de gegevens zijn 'ontstaan' en, tenminste gedeeltelijk, hoe ze 'gelezen' moeten worden. De gegevens gaan daarmee lijken op data die bij een wetenschappelijk experiment onder gecontroleerde omstandigheden, of door middel van enquêtes zijn bijeengebracht.

Het is voor wetenschappers belangrijk vast te stellen dat hun gegevens niet op toeval berusten. Als het onmogelijk is de gegevens experimenteel te verwerven, zoals bij de geschiedenis, dan kan men zich gedwongen voelen grote hoeveelheden gegevens uit de bronnen bijeen te brengen en met statistische methodes te laten zien dat de toevalsfactor binnen redelijke perken blijft, wat algemene (generaliserende) conclusies mogelijk maakt. Dat is dan ook een typerende eigenschap van het werk van Fogel en Engerman. Ze hebben duizenden en duizenden gegevens onder dezelfde noemers gebracht om er mee te kunnen rekenen. Fogel en Engerman zijn hun grootscheepse kwantitatieve onderzoek begonnen omdat ze er op vertrouwden dat cijfers hen minder zouden bedriegen dan 
kwantificatie kan niet zonder interpretatie

4.1 .3

selectie van gegevens

Parkers studie als voorbeeld bijvoorbeeld verhalen van degenen die de slavernij hebben meegemaakt. Ze vertrouwen de feiten in hun gekwantificeerde vorm omdat het toeval onder controle gebracht wordt.

Het is niet toevallig dat juist sociaal- en economisch-historici zich bij de cliometrie thuis voelen. De kwantitatieve benadering in het historisch onderzoek geeft de onderzoekers het idee dat de conclusies over de historische werkelijkheid 'objectiever' zijn, minder afhankelijk van de persoonlijkheid of de vooropgezette ideeën van de onderzoekers. De onderzoekers proberen, net als de experimentele fonetiek, te ontkomen aan het gebruik van gegevens die ieder apart interpretatie behoeven. De uitkomsten van zo'n onderzoek, de statistieken zelf, vragen natuurlijk alsnog om een interpretatie ervan in een groter geheel van kennis. De kaders voor die interpretatie worden enerzijds verschaft door theorieën die veelal aan de sociale wetenschappen of de economie zijn ontleend en anderzijds door historische kennis die op de traditionele wijze is verworven. Als toetssteen voor theorieën over sociale structuren die niet meer bestaan, lijkt de cliometrie onvervangbaar. Maar niet alles in het verleden is telbaar.

Manipulatie van de werkelijkheid 3: selectie van gegevens; afbakening van het onderzoeksterrein

Wetenschappers selecteren uiteraard ook gegevens. Selectie betekent een onderscheid maken tussen stukken van de werkelijkheid die voor observatie in aanmerking komen en te verwaarlozen stukken van de werkelijkheid. Ook dat is een vorm van manipulatie.

We kiezen als voorbeeld een studie uit 1979 van de Britse historicus Geoffrey Parker, Europe in crisis 1598-1648. Parker begint met een beschrijving van wat bekend staat als de 'defenestratie van Praag': op 23 mei 1618 werden er in Praag drie katholieke leden van de Raad van State van Bohemen uit het raam gegooid door een grote deputatie protestantse leden van de staten (het parlement) van Bohemen. Het is, zegt Parker, 'the best known single event of seventeenth century European history'.

Na de schildering van deze scène merkt Parker op dat er in het midden van de zeventiende eeuw overal in Europa onrust heerste: in Rusland, Frankrijk, Engeland, de Pfaltz, Bohemen, Duitsland, Catalonië, Portugal, Ierland, Engeland, Schotland, Holland, Zweden, Italië, de Oekraïne, Moskou en het Ottomaanse rijk, en ook buiten Europa: in Brazilië, Marokko, India en China. Daarnaast waren er nog tal van boerenopstanden en rellen in steden. In de Provence in Frankrijk met slechts 600.00o inwoners waren in de zeventiende eeuw 400 opstanden; 66 daarvan hadden plaats tussen 1648 en 1653 . In Aquitanië waren er 500 opstanden. 
de'defenestratie van Praag' als ideaaltype

selecteren en afbakenen

narratieve substanties
'[...] a similar pattern of revolt, reaching something of a crescendo in the 1640 s and ' 50 s, has been discovered in almost every area where historians have cared to look.' (Parker 1979: 18-19) De sociale onrust levert Parker het onderwerp van zijn studie. Om het onderwerp te introduceren bij de lezers selecteert Parker een gebeurtenis: de boven genoemde 'defenestratie van Praag'. Door deze gebeurtenis te selecteren geeft Parker aan de werkelijkheid een bepaalde structuur. Waarop berust de selectie? Aangenomen mag worden dat Parker van mening is dat de gebeurtenis kenmerkend is voor de sociale onrust in het Europa van de zeventiende eeuw. Hoe opvallend de gebeurtenis in de geschiedenis van Europa van die tijd ook geweest mag zijn, het is de beslissing van de historicus juist deze gebeurtenis te selecteren om de markerende rol te vervullen die hij kennelijk speelt. De visie van de historicus maakt deze gebeurtenis tot een prototype van de crisisverschijnselen in de periode daarna. De 'defenestratie van Praag' is evident een unieke, structuurmarkerende gebeurtenis zoals we in de aanhef van deze paragraaf bedoelden. In de terminologie van Max Weber: het is een 'ideaaltypische' opstand.

Het is in de beschrijvende alfavakken gebruikelijk dat onderzoekers hun onderzoeksterrein afbakenen. Wat ze daarmee bedoelen is dat ze de grenzen aangeven waarbinnen ze de werkelijkheid willen leren kennen, en waarbuiten de werkelijkheid niet meedoet in het onderzoek. Het is een belangrijke stap, vooral als het onderzoeksobject zelf geen 'natuurlijke' grenzen kent. Een tekst heeft een 'natuurlijke' begrenzing: er is een begin en een eind aan. Een schilderij ook: daar zit een lijst omheen. Maar onderzoeksobjecten zijn niet altijd op zo'n natuurlijke manier in de werkelijkheid afgebakend. In de historische vakken dus, met name bij de geschiedschrijving, bestaan die grenzen niet, en er zijn ook geen theorieën waaraan ideeën omtrent de afbakening kunnen worden ontleend. Toch zijn grenzen noodzakelijk. Hier komen historische begrippen te hulp. Quasi-precies afgebakende periodes zoals 'de Franse Revolutie', 'de Renaissance', 'de reformatie', 'de gouden eeuw', 'de Tweede Wereldoorlog', 'het empire,' 'de industriële revolutie' zorgen voor 'grenzen'. Met deze termen bakenen historici een tijdvak en een aantal gebeurtenissen en veranderingen af. De begin- en eindpunten zijn niet in de werkelijkheid aanwezig.

De Nederlandse historicus-filosoof Ankersmit heeft de afgebakende stukken historische werkelijkheid narratieve substanties gedoopt. Ze structureren het verhaal van het verleden. Ze geven de (verhalende) historicus de gelegenheid om een samenhang te creëren die de werkelijkheid enigermate overzichtelijk maakt.

Naar analogie van de historische narratieve substanties kan men ook zeggen dat 'de Nederlandse letterkunde' of 'de beeldende kunst' structurerende afbakeningen van de werkelijkheid zijn en voor de onderzoekers 
zijn de afbakeningen

willekeurig of

kunnen ze empirisch worden gerechtvaardigd of weerlegd?

4.1.4

gegevens, data en feiten

het begrip 'feit' als narratieve substanties fungeren. Iemand die over de schilderkunst van de zeventiende eeuw schrijft, heeft zijn werkterrein naar twee kanten afgebakend. Als object van studie wordt schilderkunst onderscheiden van andere cultuuruitingen, als periode is de zeventiende eeuw afgebakend van de andere tijdvakken. In beide afbakeningen zit iets willekeurigs. De schilderkunst van de zeventiende eeuw is net als de Franse Revolutie een uitvinding van de onderzoekers, zo zegt men wel. Nu zou men zich de vraag kunnen stellen of zulke concepten mogelijk naar de niet waarneembare werkelijkheid verwijzen waartoe de wetenschapper toegang wil krijgen. Deze vraag beantwoordt Ankersmit ontkennend. Volgens hem zijn deze afbakeningen geen constructies waarvoor de werkelijkheid een rechtvaardiging kan leveren. De historicus is autonoom; of liever gezegd, de traditie der geschiedschrijving is autonoom in het bepalen van de narratieve substanties. We kunnen hun bestaan niet aannemelijk maken door er beweringen uit af te leiden die we aan de werkelijkheid kunnen toetsen.

Hier is tegen ingebracht dat de praktijk soms anders is. Waar het vijftig jaar geleden nog gebruikelijk was om de Tachtigjarige Oorlog (15681648) als een heldere narratieve substantie te hanteren, spreken historici daar tegenwoordig liever niet meer over. De narratieve substantie is, naar het schijnt op empirische gronden, vervangen (in onbruik geraakt? gefalsifieerd?) door de narratieve substantie De Opstand (van de Noordelijke Nederlanden tegen de Spaanse koning).

\section{Feiten}

Ook al worden de begrippen gegevens, data en feiten nogal eens door elkaar gebruikt, het heeft zin ze uit elkaar te houden. We zullen proberen de begrippen gegevens en data aan de ene kant en feiten aan de andere kant te onderscheiden. Feit is een breder begrip dan de andere: gegevens en data zijn een bijzonder soort feit.

We gebruiken in de omgangstaal het begrip feit wat gemakkelijker dan de begrippen gegevens en data. We beschouwen data als een aan het Engels ontleend vernederlandst woord, dat het equivalent is van gegevens. We zullen gegevens en data verder door elkaar gebruiken. We reserveren die begrippen voor onderdelen van de werkelijkheid; het zijn de kleinste stukjes van de werkelijkheid die we waarnemen. Het begrip feit gebruiken we ruimer. We noemen ook wel dingen een feit die we niet onmiddellijk kunnen waarnemen. We kijken hier nog wat preciezer naar.

Wat is een feit? Wanneer noemen we iets een feit? Op het eerste gezicht lijken er een paar dingen daaromtrent wel duidelijk. Een feit is iets in de werkelijkheid, niet iets 'in ons hoofd'. We noemen iets pas een feit als de 
niet alles wat we een feit noemen, zullen we zelf vastgesteld hebben

verschil tussen de noties 'gegevens' en 'feiten'

soorten feiten werkelijkheid daartoe aanleiding geeft. Als we zeggen dat het een feit is dat het regent, dan bedoelen we in de eerste plaats dat het regenen zich werkelijk voordoet. Maar we bedoelen er nog iets meer mee: we bedoelen ook dat we het regenen hebben vastgesteld, dat we het zien regenen of horen regenen of voelen regenen. Ons kenvermogen heeft het regenen geregistreerd. 'Feiten' noemen we de dingen van de werkelijkheid die we kunnen vaststellen.

Met 'vaststellen' bedoelen we niet alleen maar 'waarnemen' in engere zin. Er zijn dingen die we 'feit' noemen die we niet kunnen zien. Dat Jan notaris is kan een feit zijn zonder dat we rechtstreeks kunnen zien dat Jan een notaris is. We kunnen het echter wel (in principe) vaststellen: we kunnen het lezen in zijn benoemingsbrief of in de krant, we kunnen het van zijn vriend gehoord hebben. We concluderen het derhalve op grond van andere vastgestelde feiten. Het feit zelf is niet waarneembaar, maar er is een manier om het vast te stellen (en daarin speelt de waarneming, hoe dan ook, een rol).

We kunnen onder bepaalde omstandigheden zeggen dat het een feit is dat de regering is afgetreden, als we in de krant hebben gelezen dat de minister-president een briefje-met-een-zekere-inhoud heeft gestuurd aan de koningin, welk briefje wij niet onder ogen hebben gehad. Historici beschouwen een groot aantal dingen als een feit, die niet rechtstreeks waarneembaar zijn. Dat is een praktische werkwijze. Het zou verwondering wekken als iedere historicus zich eerst over de primaire gegevens (de bronnen) van de Slag om Arnhem zou moeten buigen, voordat hij zou aanvaarden dat de Slag om Arnhem heeft plaatsgevonden.

Op die manier beschouwen we dus een groot aantal dingen als een feit, als vaststaand, ook al hebben we ze niet waargenomen, ook al zijn ze niet rechtstreeks waarneembaar. Voldoende om iets een feit te noemen, is de 'vaststelbaarheid-in-principe' ervan. Hier ligt een verschil met de begrippen gegevens en data. Die begrippen gebruiken we voor dingen van de werkelijkheid die onmiddellijk en rechtstreeks zijn waargenomen. Dingen dus die we niet nog eens uit andere dingen behoeven af te leiden. Van wat voor zaken in de werkelijkheid kunnen we zeggen dat ze een feit kunnen zijn?

- Sommige feiten zijn (statische) standen van zaken:'deze appel is rood'; 'de vrijheid van meningsuiting is vastgelegd in de grondwet'; 'het woord "appel" is een zelfstandig naamwoord, zijn hier voorbeelden van.

- Sommige feiten zijn gebeurtenissen, veranderingen in de werkelijkheid met een gemarkeerd begin- en eindpunt:' $e r$ is een meteoriet ingeslagen'; 'de invasie van Normandië begon op 6 juni 1944'.

- Sommige feiten zijn processen, veranderingen in de werkelijkheid zonder gemarkeerd begin- of eindpunt: 'de aarde draait om de zon'; 'het inwonersaantal van Amsterdam is de laatste twee decennia gedaald'. 
feit op grond van inlevingsvermogen van de waarnemer

feiten worden uit de werkelijkheid door het kennend subject geïsoleerd

wat als feit wordt erkend is afhankelijk van waarnemingsmogelijkheden
Van de gegeven voorbeelden zal het duidelijk zijn dat dit inderdaad het soort dingen is die (onder bepaalde omstandigheden) 'feit' genoemd kunnen worden.

Ook na het bovenstaande is het niet meteen duidelijk of we ook beweringen over 'waarden', over 'belevingen' of over 'esthetische kwaliteiten' (kwesties van 'mooi' en 'lelijk') als feit kunnen aanmerken. Beweringen als 'haar hele optreden is vertrouwenwekkend', 'het publiek heeft genoten', 'de voorstelling was grandioos' lijken moeilijk de status van 'feit' te kunnen krijgen. (Frye 1957: 20) We aanvaarden de juistheid ervan ook niet zonder meer op grond van de getuigenis van anderen. Het is mogelijk dat dit samenhangt met het feit dat de beweringen niet gebaseerd zijn op de vaststelbaarheid-in-principe van ieder die wil zien, maar op rapportages van diegene die als subject daarin was betrokken. Die waarnemer neemt (bij zichzelf) waar. Buitenstaanders kunnen die waarnemingen slechts als getuigenis al of niet overnemen. Deze verklaring veronderstelt dat een bewering gebaseerd op zintuiglijke waarneming 'objectiever' is - want gemakkelijker op grond van een getuigenis te aanvaarden - dan een bewering die ook inleving veronderstelt.

Wat bepaalt nu dat de genoemde dingen (onder bepaalde omstandigheden) feit genoemd worden? Er is in de werkelijkheid immers geen signalement van 'feiten'. In de onophoudelijke stroom van gebeurtenissen en processen, van veranderende en gelijkblijvende standen van zaken is er een aantal dat daaruit door ons verstand kan worden geïsoleerd. Hoe dat in het alledaagse leven precies gebeurt, is hier minder terzake, dan dat het gebeurt. Kennelijk heeft de beschikbaarheid van concepten en woorden om de werkelijkheid te benoemen er mee te maken, maar ook de behoefte van een persoon om de werkelijkheid een structuur te geven is erop van invloed. Wat we (onder omstandigheden) een feit noemen is afhankelijk van de vraag of we het door waar te nemen uit het totaal van de werkelijkheid kunnen en willen isoleren. Feiten dienen zich niet aan. Wat feit is, is mede afhankelijk van onze geest, die de waarneming stuurt, die selecteert en isoleert.

Wat we als feit uit de werkelijkheid kunnen isoleren is ook afhankelijk van de waarnemingstechnieken die ons ter beschikking staan en ligt geenszins voor alle eeuwigheid vast. Het duurde tot de uitvinding van de fotografie dat iemand, Muybridge, in 1877 op een foto kon vastleggen dat een dravend paard als deel van de drafbeweging soms met geen enkele poot de grond raakt, terwijl men toch iedere dag paarden zag draven. We constateerden al eerder dat wat er nu over de werkelijkheid kan worden vastgesteld, aanmerkelijk veel meer is dan vroeger mogelijk was. Wat feiten zijn, is dus afhankelijk van wat kan worden waargenomen. Aangezien waarnemingstechnieken verbeterd kunnen worden, moeten we toegeven dat wat we nu 'met eigen ogen' kunnen waarnemen mogelijk toch 
onbevangen waarneming bestaat niet

'damessandaal' niet waar is. En wat op het eerste gezicht wellicht nog verbazingwekkender is, is dat de feiten afhankelijk zijn van de behoefte van de onderzoeker. Dat wil zeggen: wat we onder omstandigheden een feit noemen is afhankelijk van de vraag of we het uit het totaal van de werkelijkheid willen isoleren.

Wat 'feiten' zijn, wordt in hoge mate bepaald door de kijk van de waarnemer. Onbevangen waarneming van de werkelijkheid in de strikte zin van het woord, dat wil zeggen waarneming zonder van tevoren een idee te hebben wat je zou kunnen aantreffen, zulke waarneming bestaat niet. De anti-psychologistische attitude van de wetenschappen is een vrome wens, eerder dan praktijk. Daar spreken we in de volgende paragraaf verder over. In hoofdstuk 7 presenteren we een principiële verklaring voor het bestaan van de spanning tussen het onvoorwaardelijke geloof in de eigen waarneming en de gewenste wetenschappelijke twijfel. Daar zullen we feiten uiteindelijk ook definiëren als die verschijnselen waarvan we menen dat ze niet voor tweeërlei uitleg vatbaar zijn.

Al deze aspecten van 'feiten' komen samen in het volgende verhaal dat in taalkundige kring enige faam geniet. Een lid van de Tweede Kamer dat deelnam aan een debat in een parlementaire commissie over de spelling van het Nederlands, zei daar dat het een feit was dat het woord damessandaal twee $[s]$-klanken bevatte. Dat kon je toch horen. (Er kon daarom volgens hem ook geen twijfel over bestaan dat het woord met twee s-en moet worden gespeld.) Fonetici echter kunnen laten zien dat op een foto van de zichtbaar gemaakte geluidsstroom geen twee $[s]$-klanken te zien zijn (zonder daar overigens consequenties voor de spelling van het woord damessandaal aan te verbinden). Geven de feiten de foneticus gelijk? Is wat het Tweede Kamer-lid zegt, niet een feit? Hij hoort toch twee s-en? Kan een zintuig toch bedriegen? Hoe beslissen de fonetici dat zij gelijk hebben? Men ziet hier de genoemde aspecten van feiten duidelijk terug.

- feiten worden door het kennend subject uit de werkelijkheid geïsoleerd;

- wat als feit telt is mede afhankelijk van de mogelijkheden van het waarnemingsvermogen;

- aan wat mensen als 'feiten' beschouwen, ontlenen ze zekerheid; ze laten zich er soms in hun gedrag door leiden;

feiten vs.opvattingen De anekdote laat ook zien dat iets voor iemand een feit kan zijn, wat voor de ander niet meer dan een opvatting is. De beroepsgroep der fonetici heeft er moeite mee te 'bewijzen' dat de leek die 'zijn eigen oren vertrouwt', ongelijk heeft, maar zal toch de impressionistische observatie van het 'ongewapende oor' van de leek niet als feit accepteren. Fonetici 
achten andere waarnemingstechnieken superieur. Het is net alsof het de expliciete of impliciete theorieën van sociale groepen zijn die bepalen wat in die groep als feit wordt beschouwd.

\section{Waarnemen, interpreteren en onder woorden brengen}

We keren nu weer terug naar het waarnemingsproces. Waar we in paragraaf 4.1. in algemene termen de werkelijkheid probeerden te beschrijven zoals de onderzoeker die waarneemt, kijken we in deze paragraaf

twee stappen in het waarnemingsproces: waarnemen en verwoorden naar de waarnemer en het waarnemen zelf. Het proces van observatie kent steeds twee stappen.

- de stap van werkelijkheid naar waarneming van de werkelijkheid,

- en de stap van waarneming van de werkelijkheid naar weergave van die waarneming in een bewering.

De eerste stap creëert de verbinding tussen een object (een 'stukje van de werkelijkheid') en het waarnemende subject. De waarnemer neemt echter niet alleen maar waar. Hij moet het waargenomene ook onder woorden brengen. Dat is de tweede stap.

Ieder van de beide stappen heeft zijn eigen problemen. Die komen respectievelijk aan bod in de paragrafen 4.2.1. en 4.2.2.

4.2 .1

kijken

\section{Waarnemen en interpreteren}

Niets lijkt zo eenvoudig als kijken. Het geel dat in mijn tuintje staat te wiegelen is onmiskenbaar een knop van een narcis. Eerlijk gezegd was ik er, zittend achter mijn computer, eerst even niet zeker van. Afgaande op de kleur zou het ook een verschrompeld restant van een kinderluchtballon kunnen zijn, of een verfrommeld stukje van een geel servetje, maar ik ben even naar het raam gelopen, en daar zag ik dat de slanke bladeren in de buurt van het geel narcissenbladeren zijn. Het geel is vandaag bovendien wat groter dan gisteren: de knop is gegroeid. Nee, alles wijst er op dat het een narcis is die ik zie. Ik weet wat ik zie. Ik heb eerder narcissen gezien, ik heb in mijn geheugen een beeld van een voorstelling van een narcis en deze gele vlek komt overeen met die geheugenvoorstelling. Als ik ook iets van het omringende groen in de beschouwing betrek, herken ik daarin de smalle bladeren van een narcis. Het idee dat het om een narcis gaat is het meest in overeenstemming met wat ik weet van een wereld met narcissen, ballonrestanten en binnengewaaide servetjes, en met de rest van wat ik zie. 
twee aspecten:

1. in- en uitzoomen

2. matching

waarnemen is interpreteren
We zien in deze beschrijving van het waarnemingsproces twee elementen. Het eerste is dat we op het waargenomen object in- en uit'zoomen'. We stellen enerzijds ons waarnemingsvermogen scherp: we lopen naar het raam om beter te kunnen zien. En we breiden anderzijds de waarneming uit tot de onmiddellijke omgeving van het object dat we willen leren kennen: we kijken of het omringende groen aanwijzingen bevat omtrent de aard van het gele object.

Het tweede element van het waarnemingsproces wordt matching genoemd. We vergelijken het waargenomene met herinneringsbeelden. Het waargenomen 'gele object' wordt gematcht met de in onze geest aanwezige beelden van 'gele dingen'; narcissen, verfrommelde gele servetjes en restjes gele luchtballon, en de waargenomen groene vorm wordt gematcht met het beeld van narcissenbladeren in onze herinnering. Ik vergelijk de beelden op mijn netvlies, met geheugenvoorstellingen; en kies voor datgene dat het meest in overeenstemming is met het waargenomene, de omgeving ervan en geheugenvoorstellingen. Van alles wat het geel zou kunnen wezen, kies ik de narcis. Waarnemen is dus ook een vorm van selectie.

Kennelijk is ons waarnemingsvermogen er op gericht om enerzijds elementen in ons blikveld te vergelijken met in het geheugen opgeslagen beelden, en anderzijds steeds tot een (voorlopige) keuze uit de beschikbare mogelijkheden te komen op grond van de informatie uit de omgeving van het object in ons blikveld. Als we willen beslissen wat we zien en we hebben de keuze uit verschillende mogelijkheden, dan kiezen we steeds dat wat waarschijnlijk past, dat wat - gegeven de kennis van de omgeving en onze verwachtingen - het meest waarschijnlijk is.

Deze pendelbeweging, dit in- en uitzoomen op het waargenomen object en matching van het waargenomene met herinneringsbeelden is op alle niveaus in waarneming herkenbaar. Ook bij 'technisch lezen' bijvoorbeeld. Woordherkenning vraagt om letterherkenning. Het waarnemen van een verticaal streepje met een vlag, van twee rondjes en een slingerlijntje leidt tot het herkennen van een $r$, een $o$, nog een $o$ en een $s$. Het waarnemen van deze letters leidt in hun onderlinge samenhang tot de waarneming van de woordvorm roos, maar soms herkennen we het woord roos eerder dan de letters waaruit het is samengesteld. Bij onzekerheid over een van de lettervormen $d$ of $r$ kan vaak met succes een beroep gedaan worden op de context Er staat een ?oos in bloei om tot de waarneming van de woordvorm roos en dus ook van de lettervorm $r$ te komen.

Dit selectie- en herkenningsproces gaat uiteraard bliksemsnel, maar dat maakt het niet minder reëel. Wat we hier aan de hand van een paar voorbeelden hebben beschreven, is een weergave van gedetailleerde psychologische onderzoekingen betreffende waarnemingsprocessen. Deze onderzoekingen leiden tot de gedachte dat waarnemen precies de 
waarnemen in onzekerheid vraagt om interpreteren

alle waarnemen heeft elementen van onzekerheid

herkennen en betekenistoekenning

in het waarnemingsproces is de hermeneutische cirkel herkenbaar

hermeneutiek kenmerken heeft van interpreteren. We willen voor dit standpunt een paar argumenten presenteren.

Wat we interpreteren noemen is een waarnemingsproces waarin meer onzekerheid dan normaal moet worden overwonnen. Bij interpreteren is sprake van afwegingen, van waarschijnlijkheden, van marges van onzekerheid. Stel, iemand kijkt naar een schilderij en zegt: 'Het lijkt wel of die persoon daar links een handschoen in zijn hand heeft. Van dichtbij zie je alleen maar een paar verfstreekjes in een afwijkende kleur. Het zou ook een sok kunnen zijn, of een slappe pet.'Vanzelf gaat de waarneming over in een interpretatie.

Maar eigenlijk verloopt alle waarneming zo; in feite kent alle waarneming een aspect van onzekerheid: alle waarnemen begint bij een nietweten omtrent een aspect van de werkelijkheid, welk niet-weten door in- en uitzoomen en matching in een weten wordt omgezet. Daar komt altijd interpretatie aan te pas.

Wat bij waarnemen herkennen is, heet in de context van interpreteren 'betekenistoekenning. We zien in het rondje een letter $o$, we zien in de gele vlek een narcis, we zien in de verfstreek een handschoen. Dat wil hetzelfde zeggen als: in de context betekent het rondje een letter $o$, de gele vlek een narcis, en de verfstreek een handschoen. Dat we de narcis kunnen interpreteren als een teken van de lente, is hetzelfde als zeggen dat we in een bepaalde context in de narcis een teken van de lente zien.

Interpreteren is vaak beschreven als een circulair proces. Een deel wordt begrepen vanuit een groter geheel, dat zelf ook weer deel is van iets groters etc., en het grotere geheel wordt begrepen op basis van de onderdelen. Een gegeven krijgt een interpretatie op grond van de omgeving waarin het gegeven wordt waargenomen. Mijn beslissing dat mijn waarneming een narcis betrof, kwam mede tot stand door de waarneming dat het groen in de omgeving van het geel het beste als narcisblad kon worden gezien. De interpretatie verloopt dus van object naar context, naar object, naar detail, naar object, naar context, naar context van de context en weer terug. Zo ontstaat het idee van een cirkelgang of een pendelbeweging. Men noemt dit proces de hermeneutische cirkel. Dezelfde cirkelgang blijkt ons waarnemingsvermogen te beheersen. In het voortdurende in- en uitzoomen op het object waarin én details én context informatie verschaffen is deze hermeneutische cirkel herkenbaar. Integratie van details met gegevens van andere niveaus van waarneming is daarbij steeds het doel.

De leer en de methode van het zoeken en rechtvaardigen van interpretaties is de hermeneutiek. Aanvankelijk ontwikkeld voor de uitleg van bijbelteksten door de Duitse theoloog Friedrich Schleiermacher (17681834) is de hermeneutiek hoe langer hoe meer geworden tot de leer en de methode van het interpreteren van alles dat maar een zin kan krijgen: 
teksten, kunstwerken, maar ook gebeurtenissen en het leven zelf. Steeds gaat het in de hermeneutiek om zingeving of betekenisgeving. Die ontstaat door de pendelbeweging tussen deel en geheel. Jansen (1991: 221) noemt als voorbeelden van zulke pendelbewegingen bij het interpreteren van literair werk:

- tussen een woord en een zin waarin het voorkomt;

- tussen een zin en de tekst waarin die voorkomt;

- tussen een enkel werk van een schrijver en diens oeuvre;

- tussen een enkel werk en het geheel van de literatuur van een bepaalde periode;

- tussen een enkel werk van een schrijver en diens leven;

- tussen het leven en werk van een individu en de 'tijdgeest'.

Uiteraard kan men op ieder niveau ook weer naar verschillende niveaus hoger of lager pendelen. Het hogere niveau is steeds context in de waarneming op het lagere niveau.

Deze intuïties worden door psychologische theorieën over waarnemingsprocessen bevestigd: die pendelbewegingen tussen deel en geheelhet in- en uitzoomen op het waar te nemen object - zijn kenmerkend voor alle waarneming.

het dagelijks gebruik van de begrippen interpreteren en waarnemen: er is slechts een gradueel verschil...

... en het gebruik van die begrippen in de humaniora: de factor'tijd'

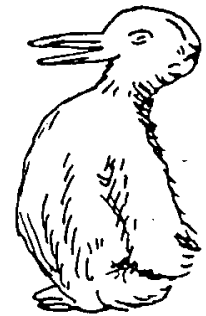

Interpreteren en waarnemen verschillen slechts van elkaar in de snelheid waarmee de zekerheid tot stand komt. In de omgangstaal lijken we speciaal dan van 'interpreteren' te spreken, als niet bij eerste oogopslag duidelijk is wat zich aan onze waarneming voordoet, als het object zo groot is dat het niet in een keer kan worden overzien, of als het object vaag is of (relatief) klein of om andere redenen niet gemakkelijk kan worden waargenomen, of als (de waarneming van) het object een verloop in de tijd kent, waardoor de waarneming uit een opeenvolging van waarnemingen is opgebouwd.

Dit komt overeen met het spraakgebruik in de geesteswetenschappen. We spreken met name van interpreteren als de factor 'tijd' in het spel is.

- Als het waarnemingsobject zo groot en rijk aan informatie is dat het niet in één keer te bevatten is, d.w.z. als er delen van het object al in het geheugen moeten zijn opgeborgen voordat het laatste deel is waargenomen: een romantekst, een gedicht, een bouwwerk, een muziekstuk;

- Als het object een object in verandering is, zoals bij 'gebeurtenissen', complexe processen, muziekstukken, taalgebruik;

- Als het object raadselachtig is, dat wil zeggen meerduidig. Als je het ene moment een eend ziet en het andere een haas. 
problemen met interpretaties

waarneming en interpretatieproblemen vergeleken
Merk op dat ook hieruit geen principieel verschil tussen waarnemen en interpreteren te voorschijn komt. Ook die dingen die we in één oogopslag kunnen waarnemen, kopjes, appels, woorden, etc. worden, zij het bliksemsnel, in hun onderdelen en kenmerken ontleed en herkend, om vervolgens weer tot een coherente gewaarwording te worden gesynthetiseerd.

Interpreteren en de interpretaties die we als de producten ervan kunnen beschouwen, zijn onderwerp van een buitengewoon levendige discussie in allerlei geesteswetenschappen. (CF. Nuchelmans e.a. 1990) De volgende vragen komen aan de orde. Heeft een gegeven aspect van gedrag (een taaluiting, een tekst, een historische gebeurtenis, een muziekstuk) één en niet meer dan één juiste interpretatie? Zijn er criteria om te bepalen of een interpretatie correct is? En hoe verhoudt een interpretatie van een gedragsaspect (een taaluiting, een tekst, een historische gebeurtenis) zich tot de bedoeling van de handelende persoon, de spreker, de schrijver? Zijn interpretaties waar? Bestaan er aantoonbaar onjuiste interpretaties? Kunnen we dit nu als waarnemingsproblemen zien?

Laten we dezelfde vragen aan het waarnemingsproces stellen. En om de persoon van de waarnemer er buiten te houden proberen we de vragen te beantwoorden voor de 'stilgezette' waarneming van foto's.

Heeft het zin om te spreken van de 'enig juiste' foto van een landschap? Kennelijk niet. Twee foto's gemaakt vanuit twee verschillende punten die 100 meter uit elkaar liggen, of twee foto's van hetzelfde landschap waarvan de eerste vanuit de lucht is gemaakt en de andere vanaf de grond, zulke foto's verschillen in principe van elkaar. Geen van de opnames kan aanspraak maken op het etiket 'enig juiste opname'. Ze kunnen allebei 'juist' heten. Twee foto's vanuit hetzelfde punt maar met verschillende toestellen gemaakt, verschillen mogelijk van elkaar. Ze zullen elkaar aanvullen. Zelfs een opname die met een slechte camera is gemaakt, kan moeilijk als een incorrecte of 'onjuiste' foto worden beschouwd. Desondanks heeft het zin om de ene foto beter te vinden dan de andere. Een foto waarop meer details zichtbaar zijn, foto's die scherper zijn, of foto's die een duidelijker structuur en samenhang in het object laten zien, zulke foto's zijn beter. Onder zekere omstandigheden kan het zinvol zijn om over 'onware' foto's te spreken. De bekende foto van Lenin als redenaar, waarop de figuur van Trotsky is weggeretoucheerd, is een 'onware' foto. Alle getrukeerde foto's zijn 'onware' foto's. Foto's kunnen ook op velerlei manieren misleidend zijn. Iedereen die foto's in vakantiefolders met de werkelijkheid heeft vergeleken, weet hoe misleidend foto's kunnen zijn, bijvoorbeeld doordat ze een zeer speciale uitsnede uit de werkelijkheid vertonen. Ook is het resultaat afhankelijk van het waarnemingsvermogen: met een zwart-witfilmpje kun je geen kleurenfoto's maken. 
toepassing op interpretaties in de humaniora

selectief waarnemen

objectiviteit in de waarneming
Al deze dingen gelden ook voor beschrijvingen of interpretaties van historische verschijnselen of van kunstwerken. Twee van zulke beschrijvingen kunnen allebei correct zijn, ook al verschillen ze van elkaar. Ze kunnen op hun kwaliteiten worden vergeleken. Ze kunnen misleidend en frauduleus zijn. Ze kunnen genuanceerd en ongenuanceerd zijn. Ze kunnen veel of weinig aandacht voor details hebben, ze kunnen veel of weinig structuur van gebeurtenissen of toestanden zichtbaar maken. Alles net als een foto of een waarneming met het blote oog. Het is niet toevallig dat gedetailleerdheid, scherpte, genuanceerdheid, waarheidsgetrouwheid, structurering en samenhang, en afwezigheid van misleiding de criteria zijn waaraan in de wetenschap interpretaties worden gemeten. Dit geldt zowel voor de interpretaties van kunstwerken als van historische verschijnselen.

We hebben opgemerkt dat twee verschillende foto's van eenzelfde object elkaar kunnen aanvullen. We moeten erkennen dat we in beginsel niet kunnen zeggen wanneer we genoeg foto's van een object hebben, om te kunnen zeggen dat we het object compleet hebben waargenomen. Dat geldt ook voor het interpreteren van historische gebeurtenissen en kunstwerken. Ook daar wordt meestal van een nieuw gepresenteerde interpretatie gezegd dat deze de bestaande niet weerlegt, maar aanvult.

Wat de fotografie niet kan, is een foto maken van uitsluitend huizen, of uitsluitend 'grote gebouwen', of uitsluitend de mensen, of uitsluitend de 'arme mensen'. De menselijke waarneming, de samenwerkingsvorm van zintuigen en verstand, kan dat wel. Zoals de zwart-witfotografie af kan zien van de kleur van de dingen, zo is de menselijke geest in staat van bepaalde andere aspecten van de werkelijkheid te abstraheren. Een beschrijving van de Utrechtse kerken in de zeventiende eeuw, of van het drankgebruik in de Amsterdamse Pijp aan het eind van de negentiende eeuw. 'Selectief waarnemen' is de menselijke geest gegeven. Maar in principe geldt voor het selectief waargenomene weer hetzelfde als hiervoor aan de hand van de fotografie over waarnemen en interpreteren werd gezegd.

Maar gaat het bij interpretatie niet altijd om een waarneming vanuit een bepaald gezichtspunt, en werkt dat gezichtspunt niet door in het resultaat? En staat dat niet op gespannen voet met het idee dat we in de wetenschap moeten proberen 'onbevangen' waar te nemen?

Dat zou misschien zo zijn, als er zoiets als objectieve, onbevangen waarneming zou bestaan. Maar dat is niet zo. We zagen dat waarneming niet mogelijk is, zonder matching, zonder dat het kennend subject gebruik maakt van wat het al van de wereld weet, en op grond daarvan verwacht te zullen waarnemen. Daar zit onvermijdelijk een subjectief element in. Dit betekent dat het anti-psychologistische standpunt van de wetenschapper, dat dicteert dat de waarneming onbevangen moet zijn, 
noodzaak van gecontroleerde observaties

waarneming theoriegeladen

zijn er ook waarnemingsprincipes die zorgen dat de subjectieve, theoriegeladen waarneming van de een niet verschillen van die van een ander?

Fodors argument

voorbeeld van werking van dit principe bij visuele waarneming eerder een 'mooi voornemen' blijft dan 'een haalbare kaart'. We kunnen niet helemaal uitsluiten dat we ons door ons waarnemingsvermogen (veel of) een beetje laten misleiden.

Dit maakt ook de voorzorgsmaatregelen nodig die we in de eerste paragraaf van dit hoofdstuk hebben behandeld: de controle over de situatie waarin de observatie wordt gedaan, zoals in het fonetisch laboratorium nagestreefd, of de behoefte observaties in 'kleine stukjes' tegelijk op te nemen, zoals we in de cliometrie tegenkwamen.

Er wordt hier een parallellie zichtbaar tussen woordbetekenissen en waarnemingen. Net als woorden een theoretische lading dragen zoals we zagen in paragraaf 2.1., zo zijn ook waarnemingen theoriegebonden. $\mathrm{Ze}$ worden gestuurd door de concepten waarover het waarnemend subject beschikt. Die concepten vormen een bij de waarnemer bestaande theorie over de werkelijkheid. Net als bij de woordbetekenissen zien we dat onderzoekers praktische oplossingen gebruiken om het probleem onder controle te houden. Ze stellen de eis dat de waarneming intersubjectief en herhaalbaar moet zijn. Daar bedoelen ze mee dat een tweede wetenschapper onder dezelfde omstandigheden hetzelfde zou moeten zien.

$\mathrm{Nu}$ zagen we echter ook, toen we spraken over het vertaalprobleem, dat het menselijk communicatief vermogen geleid wordt door principes, zoals het rationaliteitsprincipe en het welwillendheidsprincipe, die er voor zorgen dat de communicatie niet ontspoort. We kunnen daarom de vraag stellen of er ook dat soort principes bestaan die er voor zorgen dat het menselijke waarnemingsvermogen betrouwbaar intersubjectief kan heten. Principes dus die de ideeën over de theoriegeladen waarneming kunnen verzoenen met het alledaagse gegeven dat we doorgaans zo weinig merken van de theoretische lading die mijn waarneming zou doen verschillen van de waarneming van die van een ander. Net als bij woorden vertrouw ik doorgaans immers blindelings op de waarneming van een ander.

Inderdaad wordt dit met klem door sommige filosofen betoogd. Jerry Fodor, Amerikaans filosoof en psycholinguist, heeft er bijvoorbeeld op gewezen dat de theoriegebondenheid van de waarneming de waarneming niet onbetrouwbaar maakt. Het is vervelend, zegt hij, dat mensen dit doorgaans aannemelijk willen maken met visuele waarneming, die we niet zo gemakkelijk kunnen controleren. Ik kan niet zo gemakkelijk het beeld van de ontluikende narcis in mijn hoofd vergelijken met het beeld van hetzelfde in andermans hoofd. We kunnen niet in onze hoofden kijken, en een getekende of geschilderde weergave zegt niet zo veel, want we kunnen niet allebei even goed tekenen of schilderen. Maar, zo gaat de redenering verder, met spraak gaat dat veel gemakkelijker. Als iemand een niet al te lange zin zegt en ik hoor die zin, kan ik die zin - als ik dezelfde taal spreek - moeiteloos herhalen. De waarneming van die zin is 

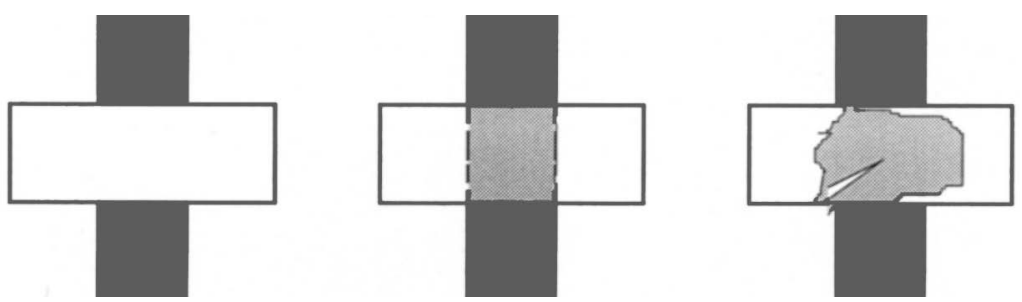

Figuur 2 De waarneming van gedeeltelijk verborgen figuren verloopt niet willekeurig. Achter de verticale pleister in de eerste figuur verwachten we lijnen zoals in de tweede, geen lijnen zoals in de derde figuur. Naar Jackendoff (1993)

geladen met de op ons natuurlijk taalvermogen gebaseerde kennis van die taal. Een zin herhalen van iemand in een taal die ik niet spreek, kan ik niet. De menselijke waarneming mag dan theoriegeladen zijn, de betrokken theorieën zijn ingeweven in het natuurlijke menselijke waarnemingsvermogen, en daarom voor alle mensen in grote lijnen gelijk.

Dat ons waarnemingsvermogen wordt gestuurd door zulke algemene principes, blijkt duidelijk uit de interpretaties van figuren als de bovenstaande.

In figuur 2 interpreteren we de linker als twee rechthoekige strips, waarvan de een over de ander ligt. We interpreteren de 'onderliggende' strip niet als de grillige figuur in de rechterfiguur. Niemand heeft ons ooit verteld dat we de figuren zo moeten interpreteren, en toch leidt dit principe ons kennelijk iedere dag als we dingen moeten waarnemen die gedeeltelijk achter andere dingen verborgen liggen.

Waarneming theoriegeladen? Ja dus, maar de betrokken theorieën zijn geen subjectieve hersenspinsels die ieder mens in zijn persoonlijke leven opdoet (en die de uitwisseling van waarnemingen een onzekere zaak zouden maken), maar het zijn (aangeboren) principes die het menselijk waarnemingsvermogen sturen.

innerlijke waarneming: images

$\mathrm{Er}$ is nog een interessant resultaat van het psychologisch waarnemingsonderzoek. Mensen zijn in staat zich beelden voor de geest te halen, zowel op basis van de herinnering als gefantaseerde. Deze innerlijke voorstellingen ('images' in het Engels) vertonen dezelfde karakteristiek als producten van geschiedschrijving.

People cannot reconstruct an image of an entire visual scene. Images are fragmentary. We recall glimpses of parts, arrange them in a mental tableau, and then do a juggling act to refresh each part as it fades. Worse, each glimpse records only the surfaces visible from one vintage point, distorted by perspective. [...] To remember an object we turn it over or walk around it, and that means our memory for it is an album of separate views. [...] images are slaves to the organization of 
objectieve waarneming bestaat niet, maar de aard van het menselijk waarnemingsvermogen zorgt ervoor dat de waarneming bij ieder mens 'regel-geleid' verloopt memory. Our knowledge of the world could not possibly fit into one big picture or map. There are too many scales, from mountains to fleas, to fit into one medium with a fixed grain size. Memory labels must be labeled and organized within a propositional superstructure, perhaps a bit like hypermedia, where graphics files are linked to attachment points within a large text or database. (Pinker 1997: 294-295)

Men ziet het geschiedverhaal voor zich: scènes die eenmaal verteld de neiging hebben onscherp te worden, in een coherent verband geschikt dat ze een organisatie geeft. Producten van geschiedschrijving worden niet toevallig vaak in visuele metaforen beschreven. Men spreekt van een 'breed panorama', van 'perspectief', van 'historisch toneel' en 'scènes'. Huizinga heeft het over de 'aanschouwelijkheid', 'beeldbaarheid' en 'schilderbaarheid' van het geschiedverhaal.

Waarneming als wetenschapstheoretisch fenomeen heeft dus de kenmerken van alle waarneming. Daarmee worden de aanspraken dat objectieve waarneming in de wetenschap mogelijk zou zijn, een waarneming dus waarin de rol van het kennend subject geheel afwezig is, principieel niet waar gemaakt. Te erkennen dat objectieve waarneming onmogelijk is heeft als consequentie dat we waarheidsaanspraken in het licht moeten stellen van de begrensde rationaliteit die ons mensen gegeven is. Daarom is het ook zo buitengewoon vruchtbaar voor de wetenschap, als het begrensde menselijke waarnemingsvermogen wordt uitgebreid met allerlei technische 'verlengstukken': verrekijkers, microscopen, fototoestellen, kunstmanen, infraroodscanners, computers etc. Net als die apparatuur aan natuurlijke, uit de aard van het apparaat voortvloeiende grenzen gebonden is, en dus ook een zekere theoretische onzekerheid meebrengt, zo geldt dat ook voor het in zijn eigen aard beperkte menselijke waarnemingsvermogen.

Willen we in de wetenschap wat aan waarnemingen/interpretaties hebben, dan moeten ze een vorm krijgen: ze moeten worden verwoord. We kunnen de parallel tussen waarnemen en interpreteren ook tot dit punt doortrekken. Zijn er immers niet ook tussen foto's verschillen die niet aan de opname kunnen worden toegeschreven, maar aan de afdruk? Daarover spreken we in de volgende paragraaf.

Waarnemen en onder woorden brengen

In de eerste paragraaf van dit hoofdstuk zeiden we dat twee stappen noodzakelijk zijn om van een object tot een bewering over dat object te komen. De eerste was dat we het object moesten waarnemen, of - wat hetzelfde is, zoals we hebben gezien - de werkelijkheid waarin het object 
opnieuw: woorden en waarnemingen zijn theoriegeladen

filosofische voorstellen om aan de theoriegeladenheid van woorden te ontkomen

soorten termen waarmee eigenschappen worden beschreven

theoretische termen in de geschiedbeoefening? voorkomt, moeten interpreteren. De tweede stap is de omzetting van het waargenomene in woorden. Zonder woorden geen wetenschappelijke kennis.

Door het kiezen van woorden voor zaken die we hebben waargenomen kennen we aan die zaken eigenschappen toe. In de keuze van de woorden verraden we gemakkelijk onze kijk op de werkelijkheid. Ze maken de beschrijving theorie- en waardegeladen. Dit hebben we eerder vastgesteld, toen we spraken over het vertaalprobleem en het waardeprobleem.

En in de vorige paragraaf voegden we daar het inzicht aan toe dat ook het waarnemen aan menselijke beperkingen onderhevig is. Beide soorten beperkingen worden in filosofische publicaties niet altijd uit elkaar gehouden.

Er is in de filosofie zeer uitvoerig gediscussieerd over de vraag of de wetenschappen aan de theoriegeladenheid van woorden en waarnemingen kunnen ontkomen. Er is betoogd (door Mach, 1858-1916) dat de wetenschap uitsluitend vertrouwen zou mogen hebben in beweringen die direct waarneembare eigenschappen verwoorden, zoals kleuren, geuren of vormen. Russell (1872-1970) en Wittgenstein (1889-1951) hebben betoogd dat alleen atomaire mededelende zinnen onbetwijfelbaar de werkelijkheid weerspiegelen. Atomaire zinnen zijn bijvoorbeeld: 'Dit ding bevindt zich naast dat ding. 'Dit ding is van aluminium' etc. Van atomaire zinnen zou gezegd kunnen worden of ze waar zijn. Alle beweringen die niet herleidbaar zijn tot atomaire beweringen, zouden geen aanspraak kunnen maken op waarheid. Carnap hechtte diezelfde waarde aan zgn. protocolzinnen: zinnen waarin nauwkeurig de elementaire bestanddelen van het waarnemingsproces zijn weergegeven. De primaire gegevens van de fonetiek, zoals we die bespraken in paragraaf 4.1.1, komen in de richting van deze atomaire beweringen en protocolzinnen. Ze zijn een beschrijving van een 'gedragsatoom': 'Proefpersoon P drukt op tijdstip $\mathrm{t}_{1}$ op het horen van geluid [ete] op knop A.' Dit zoeken naar minimale beweringen die als kennisatomen rechtstreeks de waarneming weerspiegelen, is uiteraard ingegeven door het anti-psychologisme, waar we in de eerste paragraaf van dit hoofdstuk over spraken.

De huidige wetenschapsfilosofie onderscheidt naast enerzijds alledaagse, vooraf begrepen termen en anderzijds observatietermen die nog het meest aan de woorden voor de 'zintuiglijke gewaarwordingen' van Mach herinneren, ook theoretische termen. We wijden nog enkele woorden aan de wijze waarop verschillende wetenschappen met theoretische termen omgaan.

Een eerste voorbeeld ontlenen we weer aan Europe in crisis van Geoffrey Parker. Als Parker zegt, zoals we zagen, dat er in Aquitanië in de zeventiende eeuw 500 opstanden zijn geweest, dan kent hij aan gebeurte- 
nissen de eigenschap 'opstand te zijn' toe. Dit roept uiteraard onmiddellijk de vraag op hoe dit gebeurt. Wanneer is een gebeurtenis een 'opstand' en wanneer is een reeks van gebeurtenissen 'twee opstanden'? De centrale these van Parker is dat het Europa van de zeventiende eeuw een Europa in crisissituatie was. En zijn studie dient om dat verschijnsel te verklaren. Centrale begrippen zoals 'opstand', 'sociale onrust', 'crisis' worden niet speciaal gedefinieerd, dat wil zeggen dat hij ze in hun niet scherpe alledaagse betekenis gebruikt. In paragraaf 2.1 zagen we al dat dit onder historici niet ongebruikelijk is: zij menen het best aan hun onderzoekstaak te kunnen voldoen door begrippen te gebruiken in hun alledaagse betekenis. (Vgl. Huizinga 1905: 12) Dat hangt ongetwijfeld hiermee samen dat de historici niet de bedoeling hebben de toestand te beschrijven die door begrippen als 'sociale onrust' of 'opstand' wordt aangeduid. Het is niet hun ambitie een theorie over 'opstanden' te verwoorden, noch willen ze generaliserende beweringen bijdragen aan onze kennis over maatschappelijke machtsverhoudingen en de veranderingen die daarin kunnen worden aangebracht. Ze willen de werkelijkheid van het verleden beschrijven in termen die begrijpelijk zijn voor hen die er niet bij geweest zijn, ook al hebben die termen weinig precieze referenten. Het gebruik van de woorden is impliciet geladen met de veronderstellingen die de prototypische intensies van die woorden vormen, en dus impliciet theoriegeladen.

Contrasteer dit met het tweede voorbeeld, dat we ontlenen aan de taalkunde. In taalkundige publicaties kan men de bewering aantreffen dat het woord appel een zelfstandig naamwoord is. De notie zelfstandig naamwoord is een taalkundige notie. Het is een begrip dat weliswaar in de omgangstaal door het onderwijs enigszins gemeengoed is geworden, maar het is typerend een taalkundige notie. Zo'n term is eigenlijk een afkorting voor een aantal eigenschappen.

Vroeger werd het begrip omschreven als 'een woord waaraan de voorstelling of het begrip van een zelfstandigheid gekoppeld is'. (Den Hertog $1973^{3}$ ) Het begrip 'zelfstandigheid' in deze omschrijving stamde uit de filosofie.

$\mathrm{Nu}$ brengt men in een omschrijving tot uitdrukking dat een zelfstandig naamwoord typerend verbonden kan worden met een van de woordjes ' $d e$ ' of ' $h e t$ '. De eigenschap 'verbonden-te-kunnen-worden-met-deof-het' is met de klankvorm en de betekenis van een aantal woorden in de taalkennis van Nederlandssprekenden opgeslagen. Met te zeggen 'appel is een zelfstandig naamwoord', duiden we derhalve een aspect van die taalkennis aan. Aangenomen wordt dat dit op een of andere manier correspondeert met de wijze waarop het woord appel in onze hersenen is gerepresenteerd. (Sturm en Van Bart 1987) De term zelfstandig naamwoord ontleent zijn betekenis (en toepasbaarheid) aan de theorie waar hij deel van uitmaakt. 
theoretische termen maken beweringen theoriegeladen
Naar gelang de theoretische gezichtspunten verschuiven, verschuiven ook de vaktermen mee. Dat zien we aan het genoemde voorbeeld. Theoretische termen zijn bij uitstek theoriegeladen. Het verschil met de theoretische lading die woorden in de omgangstaal hebben, is gelegen in het feit dat de lading van de laatste niet in een theorie expliciet is gemaakt.

Beweringen waarin theoretische termen voorkomen zijn eveneens theoriegeladen. Hun betekenis bevat theoretische veronderstellingen. Dit behoeft uiteraard geen verder betoog. 


\section{5 \\ Onderzoekers op zoek naar de waarheid}

soorten onderzoeksresultaten

trivialiteiten als manifestatie van een wet of regelmaat

\section{Verklaren 1}

Het vaststellen van de werkelijkheid als verzameling trivialiteiten is niet het doel van de wetenschap. Observaties van de triviale werkelijkheid zijn een middel dat andere doelen dient. Over die doelen gaat het in dit hoofdstuk.

De wetenschappen zoeken op verschillende manieren naar relaties tussen de rechtstreeks waarneembare 'stukjes' van de werkelijkheid en de door de wetenschappen te produceren kennis. We stellen vier soorten relaties aan de orde:

- verklaren;

- begrijpen;

- ordenen en classificeren;

- het bouwen van modellen.

In de volgende vier deelparagrafen gaan we op deze vier soorten relaties dieperin.

Eerder zeiden we dat wetenschappers een werkelijkheid willen ontraadselen die niet rechtstreeks waarneembaar is. Zij willen geen oppervlakkigheid, zij willen inzicht; zij willen geen trivialiteiten, zij willen verbanden leren zien, zij willen verklaren. Zij gaan ervan uit dat de werkelijkheid niet een chaotische verzameling trivialiteiten is, maar dat de werkelijkheid (op zijn minst gedeeltelijk) geordend is. De werkelijkheid gehoorzaamt aan wetten. De wetenschap rekent het zich tot taak die wetten te ontdekken. De wetenschap is, zoals dat heet, nomothetisch (letterlijk: 'wetten opstellend'). Ze zoekt de geordendheid van de werkelijkheid in een regelmaat die de uitdrukking is van oorzakelijke verbanden. Een enkele, op zichzelf onbetekenende, triviale gebeurtenis is dan een uitvloeisel van die wet. Wetmatige relaties tussen twee (soorten) verschijnselen hebben altijd de vorm van generaliserende uitspraken. Ze brengen altijd tot uitdrukking dat het ene verschijnsel steeds optreedt als het andere verschijnsel optreedt. Een wet kent geen uitzonderingen. 
de begrippen 'theorie' en 'hypothese'

feiten en theorieën

de cyclische relatie tussen feiten en theorie: de empirische cyclus
Een verzameling beweringen die een ordening aanbrengt in een deel van de werkelijkheid, noemen we een theorie. Onderdelen van een theorie worden wel hypotheses genoemd. Een verzameling samenhangende hypotheses heet dan een theorie. Een scherp onderscheid bestaat hier echter niet. De termen hypothese en theorie worden veel door elkaar gebruikt.

Op welke manier brengen onderzoekers een relatie aan tussen feiten en theorieën? In eerste instantie kan deze relatie tussen feiten en theorieën worden gezien als een brug. Onderzoekers hebben vaak het idee dat ze in het onderzoek een brug proberen te slaan tussen de gegevens aan de ene kant en de vermoedens over de samenhang tussen de gegevens aan de andere kant. De gegevens moeten in overeenstemming zijn met de vermoedens die er de samenhang tussen creëren. En de vermoedens moeten in overeenstemming zijn met alle facetten van de werkelijkheid die met het vermoeden in verband gebracht kunnen worden. De vermoedens kunnen derhalve aanleiding zijn om naar speciale feiten op zoek te gaan. De vermoedens voorspellen als het ware het bestaan van die speciale feiten. Dat leidt tot die vormen van manipulatie van de werkelijkheid die we experimenteren noemen.

Daarom kan de relatie tussen feiten en theorie beter worden beschreven als een cyclische. Dat gaat ongeveer als volgt.

(a) Er is een vermoeden;

(b) Uit dat vermoeden worden door deductie beweringen afgeleid over de waarneembare werkelijkheid; die beweringen doen derhalve een voorspelling hoe de werkelijkheid er uit zal zien;

(c) Door observatie of experiment wordt getoetst of deze beweringen inderdaad in overeenstemming zijn met de werkelijkheid: er wordt gekeken of de werkelijkheid is, zoals hij op grond van het vermoeden zou moeten zijn;

(d) Zo niet, dan wordt er (mede op basis van de waarnemingen) door inductie een nieuw vermoeden geformuleerd; en kan zich het proces (b) $\mathrm{t} / \mathrm{m}$ (e) herhalen;

(e) Zo ja, dan wordt geprobeerd de zo pas bevestigde theorie een groter bereik te geven; ook hier kan zich het proces (b) $t / m$ (e) vervolgens herhalen.

Uit deze verschillende stappen is duidelijk het cyclische karakter van onderzoek af te lezen. Men spreekt bij het empirisch onderzoek dan ook wel van de empirische cyclus. Men herkent in dit vijftal stappen ook de heenen-weerbeweging via deductie en inductie die we in paragraaf 2.3 als de hypothetisch-deductieve werkwijze hebben leren kennen. Vermoedens worden getoetst aan de waargenomen werkelijkheid; de waargenomen 
succes van de empirische cyclus:

een vermoeden wordt bevestigd

er duikt een nieuw vermoeden op werkelijkheid geeft aanleiding tot vermoedens. Of - en in afwisseling - in de omgekeerde volgorde: waarnemingen geven aanleiding tot bepaalde vermoedens, en die vermoedens worden getoetst aan aspecten van de waarneembare werkelijkheid. Men ziet dat de cyclus steeds inductie en deductie vereist.

Wanneer beschouwen we dit proces als een succes? Dit is het geval in twee situaties.

- Er is een gevoel van succes, als een vermoeden bij herhaling op cruciale wijze de toetsing aan de werkelijkheid doorstaat; of anders gezegd, als de uit het vermoeden af te leiden beweringen die tot de empirische inhoud van het vermoeden behoren, in overeenstemming zijn met de werkelijkheid. Het vermoeden wordt, zo zegt men, door de tests bevestigd. De zekerheid omtrent het vermoeden is toegenomen. In termen van de boom van deducties: als $\mathrm{P}_{6}$ correspondeert met de werkelijkheid neemt de zekerheid van het vermoeden $P$ toe.

- Er is ook een gevoel van succes, als theorieën aanleiding geven tot een onverwacht vermoeden; hoe onverwachter hoe beter, in zekere zin. Want uit een onverwacht vermoeden kunnen veel nieuwe te toetsen beweringen worden afgeleid. Als die nieuwe uit het vermoeden afgeleide beweringen correct blijken, wordt er gezegd dat er voor het vermoeden onafhankelijke evidentie bestaat. Het vermoeden blijkt rijker (er kan meer omtrent de werkelijkheid uit afgeleid worden) dan de waarnemingen die tot het vermoeden aanleiding gaven. Het vermoeden zelf werkt productief, omdat het aanleiding geeft tot nieuwe vermoedens.

de empirische cyclus is soms een vicieuze cirkel: ad hoctheorieën

unificatie
Een theorie waar alleen de al bekende feiten uit kunnen worden afgeleid, wordt ad hoc genoemd. Zo'n theorie verklaart niks. Befaamd is het voorbeeld van Popper, dat goed de absurditeit van een ad hoc-theorie aangeeft.

'Why is the sea so rough today?'

'Because Neptune is very angry.'

'By what evidence can you support your statement that

Neptune is very angry?'

'Oh, don't you see how very rough the sea is? And is it not always rough when Neptune is angry?' (Popper 1985: 163)

De theorie (de boosheid van Neptunus) kan blijkbaar slechts de waarneming (de hoge golven) verklaren, en is dus ad hoc. Ad hoc-theorieën herschrijven in andere bewoordingen wat in waarnemingen beschreven is. Succes in de wetenschap daarentegen ontstaat daar waar theorieën 
een theorie verklaart de feiten

theorieën zijn waar in zoverre ze corresponderen met de werkelijkheid

5.1 .1

klankwetten

1. een eerste observatie

2. een eerste hypothese zich onder één (unificerende) theorie laten onderbrengen, die meer af te leiden beweringen mede gaan omvatten, en daardoor dus rijker of algemener worden.

Van de algemene bewering wordt nu gezegd dat die de feiten verklaart. Dat dit samenspel tussen theorie en feiten ontrolt zich als de initiële condities vervuld zijn.

De initiële condities zorgen ervoor dat de verklarende kracht die in de algemene bewering, de theorie, ligt opgesloten gaat werken, zodat het feit optreedt. De initiële condities zijn zo gezien dus de oorzaak van het 'stukje werkelijkheid' dat uit de theorie kan worden afgeleid. Ze veroorzaken dus het feit, maar ze kunnen dat omdat het feit in zekere zin al opgesloten ligt in de algemene bewering waaruit het kan worden afgeleid.

Zolang er uit een vermoeden dat een aantal malen door de feiten is ondersteund, geen empirische beweringen afgeleid kunnen worden die strijdig zijn met de werkelijkheid, wordt het vermoeden voor waar gehouden. Het vermoeden, zo zegt men, correspondeert met de werkelijkheid. De werkelijkheid komt overeen met een stand van zaken die in het vermoeden, de theorie, beschreven wordt. We ontmoeten hier de meest gangbare waarheidsopvatting of waarheidstheorie. Deze correspondentietheorie van waarheid zegt dat waarheid hetzelfde is als correspondentie met de werkelijkheid.

\section{Een voorbeeld}

We willen wat in het voorgaande in algemene bewoordingen is uiteengezet, in deze subparagraaf toelichten aan de hand van een voorbeeld dat twee polen van de letteren lijkt te omspannen: de taal en de geschiedenis. Het voorbeeld is dat van de klankwetten. Het kent tien stappen.

Wie een beetje Duits en Nederlands kent, zal het wel eens zijn opgevallen dat er in het Duits vaak zelfstandige naamwoorden met [ $p f]$ beginnen, terwijl verwante woorden in het Nederlands met een $[p]$ beginnen. Een paar voorbeelden vindt men in het volgende rijtje.

$\begin{array}{ll}\text { Pfund } & \text { pond } \\ \text { Pferd } & \text { paard } \\ \text { Pfeife } & \text { pijp } \\ \text { Pfeffer } & \text { peper }\end{array}$

Dit is een eerste observatie.

Het is niet moeilijk om van hier uit via inductie tot een bewering te komen als de volgende. 
3. toetsing

4. andere vermoedens

5. verbreding van het observatieterrein
6. verbreding van de hypothese: de Hoogduitse klankverschuiving
Naast ieder Duits woord dat met een $[p f]$-klank begint, heeft het Nederlands een woord dat ongeveer hetzelfde betekent en ongeveer hetzelfde klinkt, met dien verstande dat het Nederlandse woord een $[p]$ heeft, waar het Duits een $[p f]$ heeft. Dit is een eerste hypothese.

Deze bewering kan men eenvoudig toetsen. Men neme een Duits woordenboek. Zoekt de woorden op die met [ $p f]$ beginnen en kijkt of het Nederlands een woord heeft, dat daarmee op de aangegeven wijze correspondeert. De regelmaat blijkt opvallend, zij het niet compleet.

Dit kan aanleiding geven tot andere vermoedens. Wat voor het Nederlands en het Duits geldt, zou ook wel eens voor Nederlandse en Duitse dialecten kunnen gelden. En wat voor de $[p f] /[p]$ geldt, zou ook wel eens voor andere klanken kunnen gelden.

Kijkt men wat beter naar de feitelijke spraak, dan blijkt dat in de dialecten in de Noordelijke helft van Duitsland, de zgn. Nederduitse dialecten steeds vormen bestaan die aansluiten bij het Nederlands, vormen met de $[p]$-klank dus, terwijl de [pf]-klank gevonden wordt in het Hoogduits, dat wil zeggen de Duitse standaardtaal en de dialecten van het (hogergelegen, bergachtiger) deel van Duitsland.

Betrekt men ook andere woorden in de beschouwing, dan blijken er nog meer systematische klankverschillen te bestaan tussen het Nederlands en de Nederduitse dialecten aan de ene kant en het Hoogduits en de Hoogduitse dialecten aan de andere kant. Hoogduitse woorden hebben een $[t s]$-klank, waar de Nederlandse en Nederduitse woorden een $[t]$-klank hebben, en we vinden Hoogduitse vormen met een $[\chi]$-klank (een harde $[g]$ ), waar het Nederlands en de Nederduitse dialecten een $[k]$ hebben. Bovendien, waar Hoogduitse vormen na een klinker een $[f]$ klank hebben, hebben het Nederlands en de Nederduitse dialecten een $[p]$. Een paar voorbeelden.

\begin{tabular}{|c|c|}
\hline Hoogduits & Nederduits/Nederlands \\
\hline [ts] Herz, setzen & [t] hart, zetten \\
\hline Dach, machen & dak, maken \\
\hline offen, waffen & open, wapen \\
\hline
\end{tabular}

Deze gegevens illustreren een klankwet. Een klankwet beschrijft een correlatie: als de ene taal of dialect (op een bepaalde plaats in een woord) een klank $x$ heeft, heeft een andere taal of dialect in het overeenkomstige woord een klank $y$. Dit kan geen toeval zijn. In een deel van een taalgebied zijn in een bepaalde periode een aantal vormen (één voor één) van klank veranderd. Een klankwet beschrijft dus ook altijd een klankverandering, een veranderingsproces. De algemene vorm van de klankwet is: de klank $x$ verandert in de omgeving van de klank $z$ in de klank $y$ in tijd T in gebied $P$. 
7. additionele gegevens

8. het algemene van de klankwetten

9. een hypothese over taalverwantschap

10. toetsing van de klankwet?
Uit allerlei additionele gegevens blijkt dat de Nederlands-Nederduitse situatie de oudste is, dat vroeger in het hele gebied waarvan hier sprake is, steeds de $[p, t, k]$-vormen zijn gebruikt, maar dat al in de vroege Middeleeuwen, onder invloed van de Volksverhuizing waarschijnlijk, de uitspraak van deze vormen in het Hoogduitse gebied is verschoven in de richting die we hebben beschreven. Het proces staat bekend als de Hoogduitse klankverschuiving. De ontdekking ervan staat op naam van Jacob Grimm (1785-1863) en werd voor het eerst beschreven in diens Deutsche Grammatik, verschenen tussen 1819 en 1837.

Klankwetten worden geacht zonder uitzondering door een hele woordenschat van een taal in een bepaald gebied te werken. Vindt men uitzonderingen, dan gaat het om woorden die op een later tijdstip in de taal zijn opgenomen, of om woorden die om een bijzondere reden zich aan het veranderingsproces hebben onttrokken. Alle uitzonderingen vragen om een eigen verklaring.

Klankwetten brengen verschillen en overeenkomsten tussen talen in kaart. Ze maken het bijvoorbeeld mogelijk te denken dat een groot aantal (alle?) talen uit dezelfde oorsprong zijn voortgekomen. Opnieuw dient zich een verbreding van de theorie aan.

Kan een klankwet getoetst worden? De klankwet en de additionele gegevens moeten daartoe een afleiding toelaten. Hoe zou die er uit kunnen zien? De klankwet voorspelt dat als er nog eens een oude Hoogduitse tekst gevonden wordt waarin een of meer tot nu toe onbekende woorden voorkomen die met $[p f]$ beginnen, er overeenkomstige woorden in het Nederlands of de Nederduitse dialecten bestaan die met $[p]$ beginnen, etc. De initiële conditie is dat er een Hoogduitse tekst opduikt waarin onbekende woorden met een beginklank [ $p f]$ voorkomen. De wet 'voorspelt' dat aan het licht zal komen dat iets zich in het verleden heeft voorgedaan. Men noemt dit wel een 'retrodictie': een 'predictie' (voorspelling) met terugwerkende kracht. Deze 'retrodictie' kan in beginsel worden getoetst; maar het opduiken van een vroeg-Hoogduitse tekst heeft een onderzoeker niet in de hand. De Hoogduitse klankverschuiving is een zeer efficiënte manier om te beschrijven welke verandering zich in de Germaanse dialecten heeft voorgedaan. Het is evenwel niet zo dat het een verschijnsel beschrijft dat, bijvoorbeeld door menselijk ingrijpen, nog eens in gang gezet zou kunnen worden. Op grond van het bestaan van de klankwet kan geen tweede Hoogduitse klankverschuiving worden voorspeld. 
nogmaals het deductief-nomologische verklaringsmodel waarschijnlijkheid: statistische regelmatigheden

\section{Verklaren 2}

$\mathrm{Na}$ onze inleidende beschouwingen en het voorbeeld in de vorige paragraaf geven we in deze paragraaf aan wat geldt als de meest algemene formulering van de wetenschappelijke verklaringswijze: het deductief-nomologische verklaringsmodel van Hempel.

Een verklaring voor het verschijnsel V wordt verschaft door een redenering $(\mathrm{R})$ waarin een of meer algemene theoretische uitspraken, de wetten $\mathrm{W}$, voorkomen en een of meer initiële condities I. Die redenering ziet er dus ongeveer zo uit:

(R) Als $\mathrm{W}^{1}, \mathrm{~W}^{2}$ etc. het geval is, en als $\mathrm{I}^{1}, \mathrm{I}^{2}$ etc. zich voordoen, dan treedt $\mathrm{V}$ op.

Het te verklaren verschijnsel $\mathrm{V}$, het explanandum, vloeit logisch voort uit het explanans, dat wil zeggen uit de wetten $\mathrm{W}^{1}, \mathrm{~W}^{2}$ etc. en de initiële condities $\mathrm{I}^{1}, \mathrm{I}^{2}$ etc. (R) maakt dat we kunnen zeggen dat we $\mathrm{V}$ begrijpen. Het optreden van $\mathrm{V}$ was te verwachten op grond van het explanans. We kunnen dus ook zeggen dat $\mathrm{V}$ door het explanans voorspeld wordt. Verklaren en voorspellen zijn eigenlijk hetzelfde onder een ander temporeel perspectief. Als $\mathrm{V}$ zich al heeft voorgedaan, wordt $\mathrm{V}$ als retrodictie verklaard door $\mathrm{W}^{1}, \mathrm{~W}^{2}$ etc. en $\mathrm{I}^{1}$, $\mathrm{I}^{2}$ etc.; als dat niet het geval is, en we zorgen er voor dat de initiële condities vervuld worden, dan wordt $\mathrm{V}$ door $\mathrm{W}^{1}, \mathrm{~W}^{2}$ etc. en $\mathrm{I}^{1}, \mathrm{I}^{2}$ etc. voorspeld. Tussen predictie en retrodictie is dus geen principieel verschil.

De wetten W beschrijven het algemene patroon. Ze omvatten, of dekken, alle verschijnselen V. De wetten noemt men om die reden in het deductief-nomologische verklaringsmodel wel 'covering laws'. Het model zelf heet daarom ook wel het 'covering law model. De initiële condities lokken het optreden van het in de wet genoemde verschijnsel uit; ze geven aan dat de in de wet voorwaardelijk genoemde omstandigheden zich feitelijk voordoen.

Toegepast op het eerste voorbeeld: de Hoogduitse klankverschuiving is een covering law. De initiële conditie die vervuld moet worden, is het vinden van een tot nu toe onbekend Hoogduits woord dat begint met een van de klanken die in de wet zijn beschreven. Samen verklaren klankwet en initiële conditie de aanwezigheid van $p / p f$-paren, en $t / t$-paren in het Nederlands en Duits.

Het komt natuurlijk ook voor, dat er statistische regelmatigheden zijn die de waarschijnlijkheid van het optreden van een verschijnsel beschrijven. Ze drukken uit hoe groot de kans is dat er een samenhang tussen twee verschijnselen bestaat. Bij een echte wet is die kans 100\%. Daar is het een beetje absurd om nog van 'kans' te spreken. Maar vaak is de samen- 
hang niet zo zuiver. Het volgende voorbeeld is ontleend aan Van Brakel en Van den Brink (1988: 169).

De waarschijnlijkheid om gegeven symptomen $\mathrm{a}^{1}, \mathrm{a}^{2}$ te genezen via behandeling $\mathrm{k}$ is $90 \%$. De patiënt A vertoonde de symptomen $\mathrm{a}^{1}, \mathrm{a}^{2}$ en is behandeld volgens $\mathrm{k}$. A is genezen. De genezing van A kan met 9o\% zekerheid aan de behandeling $\mathrm{k}$ worden toegeschreven.

De verklaring in dit voorbeeld wordt een inductief-statistische verklaring genoemd. Het is onduidelijk of hier wel van 'verklaren' kan worden gesproken. Immers, we begrijpen nog steeds eigenlijk niet waarom $\mathrm{k}$ in A's geval wel heeft gewerkt, en in $10 \%$ van de gevallen niet werkt.

diepte als kwaliteit

Het verklaringsmodel leidt er als het ware vanzelf toe dat covering laws zelf ook weer onder het bereik van wetten worden gebracht. Dat zagen we in het eerste voorbeeld op het moment dat we de stap namen ons observatieterrein te verbreden. In termen van de boom van deducties: $\mathrm{P}$ kan zelf weer aan een tak hangen, die samen met andere takken uit een hoger gelegen knooppunt komt. Hoe langer hoe meer verschijnselen worden daardoor uit wetten deduceerbaar en voorspelbaar. De kwaliteit van covering laws is dan ook 'diepte'. Een inzicht, een vermoeden, een theorie heet dieper naarmate er meer van de werkelijkheid mee kan worden verklaard.

de geschied-

beoefening en het covering law-model

Het zoeken van een verklaring voor een gegeven verschijnsel komt dus neer op het zoeken van een wet, die de condities aangeeft, waaronder het verschijnsel optreedt. Vanuit een positivistische visie op de wetenschappen is als eis gesteld dat wetenschappen zich op het zoeken naar dergelijke wetten zouden toeleggen. Hempel, de wetenschapsfilosoof die het genoemde deductief-nomologische verklaringsmodel en het inductief-statistische verklaringsmodel beschreef, heeft betoogd dat wetenschappen aan het deductief-nomologische verklaringsmodel herkenbaar zouden moeten zijn. Als een dergelijk model in een vakgebied niet zou worden gevolgd, zou dat vakgebied geen wetenschap genoemd kunnen worden. Het model heeft daarom met name bij de geschiedbeoefenaren voor opschudding gezorgd. Dat is begrijpelijk, omdat in feite geëist wordt dat historische verschijnselen in termen van wetten worden gepresenteerd. Die wetten zouden als de eigenlijke opbrengst van het historisch onderzoek moeten gelden. Historici echter zijn niet uit op 'verklaringen' in termen zoals hier verondersteld. Historici hebben eerder de neiging om verschijnselen te verklaren door een beroep te doen op common sense-inzichten in het sociaal functioneren van mensen en groepen. Verklaringen die gebaseerd zijn op common sense-uitspraken veronderstellen de juistheid van die algemene beweringen in plaats van die te onderzoeken. 
kent de geschiedenis wetten?

ja, meenden sommigen vroeger

nee, is nu de algemene opinie

trivialiteiten krijgen een plaats in een samenhang

een voorbeeld van niet-wetmatig inzicht

één handtekening...
Is het desondanks denkbaar dat de loop van de geschiedenis uit wetten zal worden verklaard? Ooit dacht men van wel. De beschikbaarheid van 'klankwetten', die wetenschapshistorisch gezien een enorm prestige hebben gehad, waren een belangrijke impuls tot dat denken. Er zijn dan ook pogingen gedaan om de loop van de wereldgeschiedenis uit historische wetten te voorspellen. Het marxisme is daar het bekendste voorbeeld van. Een ander voorbeeld is de voorspelling over de ondergang van de westerse beschaving van Oswald Spengler in Die Untergang des Abendlandes (1918-1922), die in de periode tussen de beide wereldoorlogen een groot prestige genoot. Spengler meende dat beschavingen gezien konden worden als 'organismen', die geboorte, bloei, verval en ondergang kenden. Alle beschavingen zouden eenzelfde ontwikkelingsgang kennen. Op grond daarvan voorspelde Spengler de ondergang van de westerse beschaving, waarvan het verval rond 1800 was ingetreden, rond het jaar 2000.

$\mathrm{Nu}$ echter wordt algemeen ingezien dat de loop van de geschiedenis wel aan allerlei wetten onderworpen is, maar niet kan worden voorspeld, omdat het aantal wetten en wetmatigheden dat op een historische verandering invloed heeft, enorm groot is, en de samenhang tussen die wetten en wetmatigheden onkenbaar complex is. De loop van de geschiedenis laat zich niet voorspellen, al was het alleen maar - zoals Popper in De Armoede van het historicisme (1967) schreef - omdat de voorspelling zelf invloed heeft op de loop van de geschiedenis.

\section{Onderzoekers zoeken samenhang: begrijpen}

Wetten zijn de uitdrukking van een ordening van gelijksoortige verschijnselen. Maar wetten zijn niet de enige vorm van ordening die mensen als rationeel accepteren. Begrip en inzicht ontstaan bijvoorbeeld ook doordat een enkele, unieke gebeurtenis een plaats krijgt in een groter geheel van gebeurtenissen.

Een voorbeeld. De Duitse componist Richard Wagner ontving na afloop van de première van zijn opera Die Meistersinger von Nürnberg in 1868 een brief van zijn mecenas Koning Ludwig II van Beieren. Wagner kreeg wel vaker brieven van de koning, maar bijzonder aan deze brief was dat hij ondertekend was met de naam Walther. Op zichzelf genomen is dit laatste feit nietszeggend en triviaal. 'Het zij zo,' kan een waarnemer opmerken, 'het staat er.'

Realiseert men zich echter dat de ondertekening Walther een uiting is van gedrag, dan ligt het voor de hand te vragen naar de intenties van het gedrag. Waarom, zo kan men vragen, ondertekent iemand, een koning, een brief niet met zijn eigen naam, maar met de naam Walther? Het 
... vier mogelijke interpretaties

bij een keuze is 'samenhang' beslissend

coherentietheorie van waarheid genoemde enkele feit: Koning Ludwig ondertekent een brief met Walther, kan een reeks van interpretaties worden gegeven, afhankelijk van de fantasie van de waarnemer van het feit. We noemen er vier.

- koning Ludwig wilde niet dat de lezer de brief kon identificeren als van hem, koning Ludwig, afkomstig;

- de koning deed maar wat; hij vertoonde wel vaker irrationeel gedrag;

- in de omgang met Richard Wagner noemde koning Ludwig zich altijd Walther;

- koning Ludwig identificeerde zich met de figuur Walther uit de opera die zojuist in première is gegaan.

Die interpretaties zijn mogelijk niet allemaal correct. Hoe kan men beslissen welke juist zijn? In het geesteswetenschappelijk onderzoek veronderstelt men dat die interpretatie correct is die past in een samenhang. De interpretatie die coherentie creëert, is correct.

Tot die samenhang kunnen de feiten behoren dat een van de hoofdfiguren van de opera Die Meistersinger von Nürnberg Walther heet, van adel is, en als groot, zij het ongeschoold liefhebber van de kunsten een heldenrol vervult in de opera. De opera zelf kon begrepen worden als een nationalistisch appèl. De première was een groot succes. De koning was al jaren een groot bewonderaar van Wagners werk, en hij identificeerde zich steeds weer opnieuw met figuren uit Wagners opera's. De ondertekening met de naam Walther in de laatste van de vier voorgestelde interpretaties past het best bij deze andere feiten, die met de bronnen kunnen worden gestaafd. (vgl. Gutman 1968: 322) Hier ontstaat een inzicht op een heel andere manier dan het inzicht dat verkregen wordt door het deductief-nomologische verklaringsmodel. Belangrijk in dit voorbeeld zijn de volgende elementen.

- Het gaat om waarneembaar gedrag.

- De onderzoeker beoogt een interpretatie van dat gedrag te geven.

- Zo'n interpretatie komt neer op een antwoord op de vraag: 'wat zou er met het gedrag bedoeld zijn?'; 'wat is de intentie?'

- Het waarneembare gedrag op zichzelf laat een aantal interpretaties toe.

- Coherentie met andere waarneembare feiten of andere interpretaties van het gedrag bepaalt de juistheid van een interpretatie.

Men kan met enig recht zeggen dat de interpretatie steun vindt in de feiten: aspecten van de totale interpretatie corresponderen met de feiten. Dat betekent dat ook hier de waarheid gedeeltelijk verklaard wordt door de correspondentietheorie van waarheid. Maar de keuze van juist de laatste 
de hermeneutische cirkel

door coherentie ontstaat begrip van de vier interpretatiemogelijkheden wordt op een andere manier gerechtvaardigd dan door de correspondentie met de werkelijkheid. De keuze berust immers op coherentie met andere gegevens. Enigszins misleidend spreekt men hier wel van de coherentietheorie van waarheid, alsof het om een andere waarheidsopvatting gaat. Coherentie speelt hier een rol als rechtvaardigingsmiddel. Op het centrale begrip samenhang, coherentie komen we terug in hoofdstuk 6.

In het genoemde geval ontstaat derhalve begrip voor een triviaal feit doordat het inpasbaar blijkt in een groter geheel. Dat beeld van het grotere geheel wordt op zijn beurt door het inpasbare gegeven versterkt. Men herkent de pendelbeweging tussen deel en geheel waar de hermeneutische cirkel om vraagt. Het effect van deze vorm van begrip zoeken is niet dat er een greep op de werkelijkheid door ontstaat, maar dat het kennende subject in het contact met de omringende werkelijkheid aan zekerheid wint. Het triviale gegeven krijgt een betekenis. Steeds als de waarneming betrekking heeft op facetten van gedrag die een bedoeling verraden, is het zoeken naar coherentie, naar samenhang de manier om een passende, c.q. de meest passende interpretatie van het gedrag te vinden, dat wil zeggen de zin van het gedrag te bepalen.

Het begrip dat daardoor ontstaat, berust ook zeker op veronderstelde causaliteit. De causale relaties zijn echter meestal niet meer dan common sense-verklaringen. Waarom, zo kunnen we bijvoorbeeld vragen, is de gekozen interpretatie van het stukje koningsgedrag een juiste? Het antwoord op die vraag doet kennelijk een beroep op het bij de lezer reeds bestaande inzicht dat mensen door hun identificatie met een van de figuren uit een (literair) kunstwerk tot uitdrukking te brengen, hun hoogachting voor het kunstwerk en voor de schepper ervan tot uitdrukking kunnen brengen. De onderzoeker in het musicologisch-historisch terrein rekent het doorgaans niet tot zijn taak alle gevallen van 'identificatie met een kunstenaar' en 'hulde brengen' in een wetmatig verband te verwoorden. Het gezochte inzicht in de werkelijkheid bestaat er in dat de dingen op een begrijpelijke plaats vallen. Daarbij wordt kennis van common sensecausale relaties doorgaans als gegeven beschouwd. Het resultaat van het onderzoek is dus ook niet een generalisatie, een algemeen inzicht, maar een uniek inzicht. De inzichten die ontstaan, zijn niet generaliseerbaar.

De inzichten zijn echter wel uitbreidbaar. Alles wijst erop - en dat is ook heel begrijpelijk - dat het een verdienste van een samenhangend geheel is, dat veel gegevens in die samenhang worden ondergebracht. De kwaliteit zit in de breedte. Zit er daarom een kern van waarheid in het idee dat geesteswetenschappelijk werk, gericht op het begrijpen van verschijnselen, eerder tot omvangrijke boeken moet leiden dan tot korte tijdschriftartikelen? 
De hierboven geillustreerde manier van begrip zoeken wordt in de wetenschapstheoretische en hermeneutische literatuur doorgaans aangeduid met het Duitse woord Verstehen. Dat woord krijgt als term zijn eigenlijke betekenis in oppositie tot de term Erklären. Begrijpen, respectievelijk verklaren zijn goede, maar in deze oppositie minder gebruikelijke, Nederlandse equivalenten. Hoewel oorspronkelijk met een andere lading geïntroduceerd, is Verstehen goed te zien als die manier van begrijpen waarbij een waarneembaar aspect van de werkelijkheid een interpretatie krijgt, waarvan de juistheid blijkt uit de inpasbaarheid in een groter geheel. Verstehen is er niet op gericht een groot aantal dezelfde verschijnselen onder een noemer te brengen. Verstehen beoogt eerder een aantal heterogene elementen van de werkelijkheid in een uniek onderling verband te bezien.

Verstehen en de eenheid van wetenschappelijke kennis
De begrippen Verstehen, interpreteren, intentie en samenhang horen bij de wetenschappen die menselijk gedrag en producten van menselijk gedrag bestuderen: de menswetenschappen, de gedragswetenschappen, de geesteswetenschappen. Daar is het begrip ook voor ingevoerd. Het onderscheid tussen Erklären en Verstehen is geïntroduceerd door de Duitse filosoof Dilthey (1833-1911). Deze meende, zoals we in ons inleidende hoofdstuk zagen, dat de geesteswetenschappen een methode hadden of moesten ontwikkelen die anders was dan die voor de natuurwetenschappen. Die methode kreeg, in onderscheid van de natuurwetenschappelijke die op Erklären gericht zou zijn, het Verstehen tot doel. Dilthey noemde 'das Verstehen grundlegend für die Geisteswissenschaften'.

Het is verleidelijk om hieruit te concluderen dat dit voortvloeit uit de objecten van onderzoek. Erklären zou voorbehouden zijn aan de objecten van de natuurwetenschappen, terwijl Verstehen exclusief voor de objecten van de geesteswetenschappen zou zijn. Daarmee zou dan tevens beslist zijn dat de 'eenheid van kennis' niet bestaat; dat het een illusie is te menen dat alle wetenschappen deel zijn van dezelfde onderneming. Dat lijkt inderdaad het standpunt van Dilthey. Het standpunt is gebaseerd op zijn mensbeeld. De mens onderscheidt zich van de natuur door 'zelfbewustzijn'. Mensen kunnen over hun eigen daden reflecteren. De objecten van de geesteswetenschappen zijn door de menselijke wil tot stand gekomen; mensen zijn verantwoordelijk voor de geschiedenis en voor de cultuur, die door menselijke inspanningen en menselijke offers tot stand zijn gebracht. De kennis van door de vrije menselijke wil veroorzaakte fenomenen vraagt om een andere methode dan de kennis omtrent de natuurverschijnselen die een mechanisch verloop kennen. Het mensbeeld van Dilthey verdraagt zich echter slecht met hedendaagse inzichten. Wij hebben veel meer het idee dat een groot deel van het menselijk doen en laten bepaald wordt door de mogelijkheden en beperkingen van onze menselijke natuur. Mensen zijn niet compleet vrij. Op basis van dit 
Verstehen en het unieke van de onderzoeksobjecten van de cultuurwetenschappen

Verstehende natuurwetenschap?

Verstehen en intentionele aspecten in de onderzoeksobjecten van de geesteswetenschappen andere mensbeeld waarin de mens een plaats in (en niet boven of buiten) de natuur inneemt, vervalt het motief voor een eigen geesteswetenschappelijke methode.

Er zijn meer redenen om geen scherpe scheiding te maken tussen natuur- en geesteswetenschappen en met dat verschil samenvallende eigen methodes. We hebben al eerder opgemerkt dat de geesteswetenschappen in belangrijke mate worden gekarakteriseerd door het feit dat hun onderzoeksobjecten vaak uniek zijn. Ieder gedicht is uniek, iedere veldslag is uniek, ieder muziekstuk is uniek, iedere historische persoon is uniek, dat wil zeggen: juist het unieke nodigt uit tot geesteswetenschappelijk onderzoek. Wat er over unieke gebeurtenissen of objecten kan worden verhelderd, beperkt zich vaak tot vragen die te maken hebben met de interne samenhang van de onderdelen van het object of met de externe samenhang van het unieke object (gebeurtenis, stand van zaken) met andere (unieke) objecten, gebeurtenissen, of standen van zaken. Om deze reden zijn de geesteswetenschappen met de Verstehende methode bijzonder vertrouwd.

Toch is het niet zo dat de natuurwetenschappen de verschijnselen uitsluitend onder het oogpunt van hun regelmatigheid interessant vinden, en daarom alleen maar in niet-unieke gebeurtenissen of processen geïnteresseerd zijn. Ons zonnestelsel, de ' big bang' (het ontstaan van het heelal), het verschuiven van de continenten, de evolutie van de natuurlijke soorten zijn als onderzoeksobject uniek en ook niet (experimenteel) voor herhaling vatbaar. Intuïtief volgen de natuurwetenschappelijke onderzoekers op die terreinen dan ook de Verstehende methode, zoals zojuist geformuleerd: ze proberen de verschijnselen te begrijpen door ze in een coherent verband te brengen met andere verschijnselen. Het grote verschil met de geesteswetenschappen is dat de natuurwetenschappen de connectie tussen de unieke feiten niet op common sense baseren, maar op onder andere omstandigheden getoetste theorieën. Ligt de rechtvaardiging van een eigen verstehende methode dan wellicht hierin dat (menselijk) gedrag om de ontraadseling van bedoelingen vraagt? Het begrip Verstehen, en de daarmee verbonden typisch geesteswetenschappelijk geachte methode, is ingevoerd met de bedoeling om menselijk gedrag en effecten van dat gedrag te kunnen beschrijven, en wel het intentionele aspect daarvan. De methode hield in zijn oorspronkelijke vorm in dat de onderzoeker zich moet verplaatsen in de geest van de handelende persoon, zich moet inleven, om als het ware van binnen uit een bepaalde cruciale beslissing van een historische persoon te kunnen beschrijven. Zo zei de kunsthistoricus Van de Wetering in een interview over het Molart-project, een onderzoeksprogramma waarin chemici en kunsthistorici samenwerken: 'We kunnen [met de nieuwe technieken] dichter op de huid van de schilders komen, zelfs in hun hersens doordringen, om te 
Verstehen en de antipsychologistische attitude van de wetenschap

is Verstehen irrationeel? zien welke beslissingen ze namen en welke consequenties die beslissingen hadden.' (Stoof 1995) Uiteraard kan men moeilijk geloven dat Van de Wetering dit letterlijk bedoelt. Als hij zou menen dat het project in hersens zal kunnen doordringen, en nog wel van dode kunstenaars, dan kan worden voorspeld dat een dergelijk ondernemen tot mislukken gedoemd is. Maar bedoelt Van de Wetering iets irrationeels?

Veel onderzoekers zijn van mening dat inleving in de geest van een ander om van binnenuit het gedrag te begrijpen, een niet-wetenschappelijke onderneming moet worden genoemd. Verstehen in deze zin leek en lijkt veel onderzoekers niet te rechtvaardigen. Intenties kun je niet waarnemen. Het subjectieve invoelingsvermogen van de onderzoeker is oncontroleerbaar. Een beroep op dat vermogen is in strijd met het antipsychologistische uitgangspunt van de wetenschap. Betekent dit dat de verstehende methode juist voor de intentionele aspecten van het menselijk gedrag - waar de methode voor is bedacht - niet bruikbaar is?

Dat is nog maar de vraag. Als Verstehen die manier van begrijpen is waarbij een waarneembaar aspect van de werkelijkheid een interpretatie krijgt, waarvan de juistheid blijkt uit de inpasbaarheid in een groter geheel, dan is bij het onderzoek van menselijk gedrag de vraag: hoe komen we daaraan, aan die mogelijke interpretaties waaruit we Verstehend een keuze maken? Hoe kwamen we bijvoorbeeld aan die vier mogelijke interpretaties van het gebruik van de naam Walther door Ludwig II? De fantasie van de onderzoeker, zeiden we hierboven. Het inlevingsvermogen van de onderzoeker, hadden we ook kunnen zeggen. Maar hier moeten we in herinnering roepen wat we eerder gezegd hebben over het verschil tussen idee en rechtvaardiging, tussen discovery en justification. In de context of discovery is het niet verboden om je creatief in te leven in de geest van een handelende persoon. Waar het bij Verstehen echter om gaat, is dat de keuze voor een (of meer) van de gevonden interpretaties gerechtvaardigd wordt, doordat deze in de samenhang past/passen. En in deze context of justification speelt het inleven geen bijzondere rol meer. Dit betekent niet dat er geen rechtvaardiging behoeft te worden gegeven, dat een bewering terecht wordt voorgesteld als een mogelijke interpretatie van een zeker aspect van een handeling; en zo'n rechtvaardiging kan nog gecompliceerd genoeg zijn, maar het inlevingsvermogen kan als bron van zo'n interpretatie moeilijk besmet en onbruikbaar verklaard worden.

Als Van de Wetering zegt dat hij in de hersenen van kunstenaars kan doordringen, om te zien wat voor beslissingen ze namen, bedoelt hij dat een aantal gissingen over de bedoelingen van de kunstenaars kunnen worden voorgesteld en getoetst; en als de toetsing uitwijst dat een gissing niet in overeenstemming is met de chemische analyse van de gebruikte verf (of andere dingen), zal die gissing moeten worden verworpen. 
Inderdaad lijkt het of we dan kunnen zien wat er in de geest van de kunstenaar is omgegaan.

Als we Verstehen opvatten als een poging om (een aspect van) gedrag of een ander verschijnsel te begrijpen door dit te interpreteren als een deel van een samenhang, lijkt het een rationele rechtvaardigingsmethode met een veel bredere toepasbaarheid dan die van het geesteswetenschappelijk onderzoek. In hoofdstuk 6 proberen we dit nog verder aannemelijk te maken.

\section{Ordening}

Er zijn nog andere manieren om inzichten te verwerven aangaande unieke verschijnselen. Daar zullen we in twee deelparagrafen twee voorbeelden van geven. We zullen laten zien dat er begrip voor verschijnselen wordt gezocht door ze in verband te brengen met een maatgevend ander verschijnsel. In een tweede deelparagraaf laten we zien dat ook het sorteren van verschijnselen en de daarvoor benodigde conceptvorming tot nagestreefde doelen van het geesteswetenschappelijk onderzoek behoren. Beide soorten gaan terug op een algemeen principe dat we eerst zullen uiteenzetten.

het unieke als een

Een manier om een uniek verschijnsel te karakteriseren is het te analyoptelsom van onderseren als een optelsom van de kenmerken ervan. Het onderstaande bescheidende algemene kenmerken oogt dat te illustreren.

Kijk naar de volgende vier figuren. Ieder van die figuren is op drie kenmerken beoordeeld:

- bestaan ze uit stukjes, ja of nee?

- zijn de figuren driedimensionaal, ja of nee?

- zijn de stukjes van gelijke grootte, ja of nee?

De uitkomsten zijn in de tabel ondergebracht. '+' betekent: het kenmerk is aanwezig, en '-' betekent dat de figuur het genoemde kenmerk niet heeft.
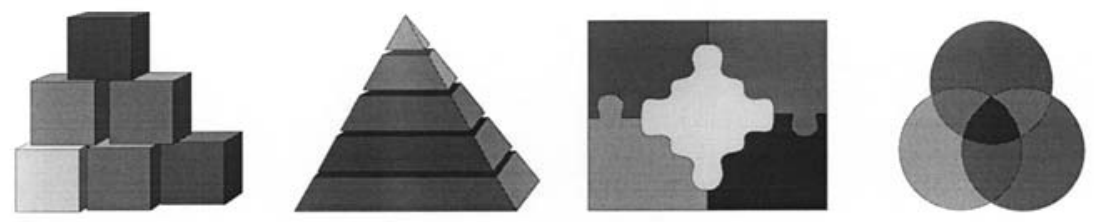

+ bestaand uit stukjes + bestaand uit stukjes + bestaand uit stukjes + bestaand uit stukjes

+ driedimensionaal +driedimensionaal -driedimensionaal -driedimensionaal

+van gelijke grootte - van gelijke grootte - van gelijke grootte + van gelijke grootte

Figuur 3 Vier figuren en hun onderscheidende kenmerken 
de toepassing van het principe: de beperkingen...

... en de mogelijkheden

$5 \cdot 3.1$

een eerste voorbeeld: fonologische kenmerken; het structuralisme
Als de wereld uit deze vier verschijnselen zou bestaan, dan zouden we de vier dingen op de aangegeven wijze uniek kunnen karakteriseren. Dat is gemakkelijk in te zien. Het stapeltje kenmerken dat we aan ze toeschrijven, is bij ieder verschillend. Ze hebben allemaal een verschillende verzameling van de kenmerken waarop we ze hebben beoordeeld. In feite zouden we het zelfs zonder het eerste kenmerk kunnen doen. Want dat blijken ze gemeenschappelijk te hebben. Natuurlijk, als de wereld meer verschillende verschijnselen kent, wordt het moeilijker. We zouden meer onderscheidende kenmerken (concepten) moeten hebben. Maar er is geen reden te bedenken dat er unieke verschijnselen zijn, die in principe niet gekarakteriseerd zouden kunnen worden als een unieke verzameling van (algemene) kenmerken. Getalsmatig zouden we aan ongeveer dertig verschillende kenmerken genoeg hebben om ieder lid van de wereldbevolking uniek te karakteriseren. Weliswaar weten we niet op voorhand welke kenmerken relevant-onderscheidend zullen blijken, maar onmogelijk is het niet.

Het is zeker niet zo dat de unieke verschijnselen die in de geesteswetenschappen worden onderzocht, steeds op de aangegeven wijze geanalyseerd worden. Per slot van rekening leert men er het unieke verschijnsel slechts mee kennen, voorzover het verschilt van andere dingen. Het aantal kenbare eigenschappen van mensen bijvoorbeeld is veel en veel groter dan de dertig waarmee iemand als individu van alle andere kan worden onderscheiden.

Desondanks herkent men de toepassing van het principe op verschillende manieren in onderzoek dat betrekking heeft op unieke dingen. In de volgende deelparagrafen bespreken we daarvan een paar typen:

- de karakterisering van iets unieks door overeenkomsten en verschillen aan te wijzen met iets anders;

- het zoeken naar relevante onderscheidende kenmerken en de conceptvorming die daar het gevolg van is.

Objecten vergelijken komt neer op het aanwijzen van overeenkomsten en verschillen. Een belangrijke kwestie is steeds wat interessante en relevante onderscheidende kenmerken zijn.

\section{Begrip door classificeren en toetsing aan een norm}

We geven een paar voorbeelden. Het systematisch determineren van een verzameling onderscheidende kenmerken voor een werkelijkheidsgebied is kenmerkend voor het structuralisme. Een succesvolle toepassing in de letteren vindt men in de fonologie. Klankinventarissen van een taal 
een tweede

voorbeeld: Jacob van

Maerlant en

Vincentius van

Beauvais

een derde voorbeeld: Van Goghs 'onhandigheid' berusten op het aanwijzen van die kenmerken van klanken die betekenisonderscheidend zijn. Het verschil tussen een [b] en een [p] berust op het al of niet gebruiken van de stembanden. Dit al of niet gebruiken van de stembanden heeft betekeniseffecten, zoals blijkt uit het naast elkaar bestaan van de woorden [pan] en [ban], en [beuken] en [peuken]. Iedere spraakklank kan met een eigen stapeltje kenmerken uniek worden gecategoriseerd.

Een tweede voorbeeld. De neerlandicus-mediëvist Van Oostrom bezorgde een bloemlezing van de Spiegel historiael van Jacob van Maerlant uit omstreeks 1285. In zijn inleiding vertelt Van Oostrom dat Van Maerlant

juist het meest recente en indrukwekkende specimen binnen [het genre 'geschiedenis van de gehele wereld'] als basis voor zijn eigen werk nam: het Speculum historiale van Vincentius van Beauvais (ca. 1250).

Tegelijkertijd merkt Van Oostrom op

dat nog nimmer in het Nederlands zich iemand aan een dergelijke ambitieuze onderneming had gewaagd; maar wist hij ook dat hij hiermee zelfs de eerste schrijver was van alle Europese volkstalen? (Van Oostrom 1995: 4-5)

Van Maerlant volgde een beroemd voorbeeld, maar was daarbij uniek in het gebruik van een andere taal dan het Latijn. Van Oostrom plaatst het werk van Van Maerlant in een perspectief door overeenkomsten en verschillen te beschrijven met het werk van Vincent van Beauvais dat als norm geldt in het genre dat Van Maerlant beoefende.

Er is vaak opgemerkt, door kunsthistorici en toeschouwers, dat Van Gogh op sommige van zijn schilderijen het menselijk voorkomen enigszins stuntelig uitbeeldt. Een goed voorbeeld vindt men in het schilderij 'De aardappeleters'. De kunsthistoricus Rummens heeft er op gewezen dat

Van Goghs gaucherie, zoals de Fransen deze onhandigheid zo mooi noemen, past in een belangrijke traditie binnen de moderne kunst, die gericht is op expressieve mogelijkheden in de schilderkunstige praktijk. (p. 28)

Onhandigheid, stunteligheid, 'gaucherie' was en is in een bepaald kader derhalve een eigenschap met een eigen traditie. Er zijn schilderijen van andere schilders die dezelfde eigenschap vertonen. Onhandigheid is zo 
classificeren veronderstelt een vergelijkingsobject

de waarde van het introduceren van een norm

nog een voorbeeld gezien een schilderkunstige waarde (en niet iets unieks), eigen aan (een fase in de ontwikkeling van) het werk van Van Gogh, dat verder uitsluitend begrepen moet worden vanuit de technische bekwaamheden en expressieve doelen van de schilder zelf. Alleen al het besef dat er voor het verschijnsel een aparte naam bestaat, geeft er iets bovenindividueels aan. Er zijn nu kennelijk vergelijkingsobjecten. Tegelijkertijd helpt het begrip het unieke van schilders als Van Gogh te herkennen tegenover andere schilders in wier werk het kenmerk ontbreekt.

De twee laatste voorbeelden laten zien dat onderzoekers vergelijkingsobjecten presenteren om het unieke te classificeren. Verschillen en overeenkomsten zijn tegelijkertijd belangrijk. Het Van Gogh-voorbeeld komt uit dat deel van de kunstgeschiedenis dat stijlanalyse wordt genoemd. De stijlanalyse probeert de intuïtie te beschrijven en te verklaren dat de werken van dezelfde kunstenaar, of uit dezelfde periode op elkaar lijken. Vergelijken en classificeren is in de stijlanalyse aan de orde van de dag. De kunsthistoricus Gombrich zei van Wölfflin, de grondlegger van de moderne kunsthistorische stilistiek: 'Sinds Wölfflin staan er twee diaprojectoren in de collegezaal.' (Willems 1993)

Het unieke wordt geclassificeerd door het in verband te brengen met prototypische verschijnselen. Soms begint een beschrijving van een reeks verschijnselen daarom met een beschrijving van een normverschijnsel dat de onderscheidende kenmerken duidelijk maakt. In de retoriek van de geschiedschrijving, de meestal ongeschreven regels voor het opzetten van een historisch panorama, speelt de keuze van een voorbeeld dat normatief werkt daarom een bijzondere rol.

We herinneren aan het begin van Europe in crisis van Parker. Door de keuze voor een beschrijving van de defenestratie van Praag als introductie van zijn boek over het door crisissen geteisterde Europa in het tijdvak 1598-1648 legde Parker een norm vast, waaraan andere crisisachtige verschijnselen af te meten zijn.

Thompsons The making of the English working class uit 1963 is een 'classic' op het gebied van de Engelse sociale geschiedenis. Het opent met een beschrijving van de scène van een eerste bijeenkomst van de London Corresponding Society in 1792, een bijeenkomst van negen 'well-meaning, sober and industrious men' die hervorming van het kiesrecht nastreven. Duidelijk is de scène gekozen omdat de bijeenkomst op een of andere manier een norm van arbeidersorganisatie zichtbaar maakt. Thompson is zich zeer bewust van het normstellende karakter van de keuze voor dit begin.

Too often, since every account must start somewhere, we see only the things which are new. We start in 1789, and English Jacobinism appears as a by-product of the French Revolution. Or we start in 1819 and 
ideaaltypen

waarom worden verschijnselen gemeten aan een norm?

politieke lading van historische vergelijkingen with Peterloo, [een bloedige door burgers en militairen uiteengeslagen demonstratie van arbeiders waarbij 11 arbeiders om het leven kwamen; T.P.] and English radicalism appears to be a spontaneous generation of the Industrial Revolution. (1963: 24)

Introducerende beschrijvingen hebben dus een normatief effect. Wat we in 4.1.3 manipulatie van de werkelijkheid noemden, ontmoeten we hier weer als een middel om inzicht te verwerven.

De Duitse socioloog en filosoof Max Weber spreekt in dit verband van ideaaltypen. Dit woord vindt men nogal eens gebruikt om de norm aan te duiden waarmee een onderzoeksobject wordt vergeleken. Een stukje van de werkelijkheid wordt door het te classificeren zowel als uniek verschijnsel erkend als een plaats gewezen. Dit classificeren gebeurt soms zonder over de oorzakelijkheid uitspraken te doen. Dat wil zeggen dat niet noodzakelijk wordt gezocht naar de oorzaak van de overeenkomst. Er hoeft ook helemaal geen causale relatie te zijn tussen het optreden van de norm en het optreden van verschijnselen die daaraan getoetst kunnen worden. De defenestratie van Praag heeft Europa niet in een crisis gestort; het heeft de andere crisissen niet veroorzaakt.

Ook stilistisch onderzoek, het onderzoek dat er op gericht is in het werk van individuele kunstenaars of in stromingen in de kunsten stijlen aan te wijzen, heeft niet als uitkomst dat het ene schilderij de oorzaak is van het andere dat er stilistisch mee overeenkomt.

Waarom worden verschijnselen gemeten aan een norm? Hoe kan dit type onderzoeksactiviteit met 'het zoeken van de waarheid' in verband gebracht worden? Dat is niet zo erg duidelijk. Het vloeit niet uit de verschijnselen zelf voort dat ze onderling vergelijkbaar zijn. Dat verschijnselen tot een bepaalde klasse van dingen behoren, is het gevolg van een bepaalde wijze van kijken. Het ideaaltype vertegenwoordigt de maat der dingen. Het introduceren van zo'n vergelijkingsobject lijkt op het gedrag van ouders die een kind de betekenis van een woord willen leren. Als je aan een kind wil uitleggen wat een citroen is, is het een betrouwbare strategie te wijzen op een mooi geel exemplaar, en niet op een grijs beschimmelde, uitgeperste of verrotte vrucht. Men scherpt met een ideaaltype het onderscheidingsvermogen.

Dat er door de classificatie begrip ontstaat, is in de bedoelde gevallen een effect van het feit dat men door het meten aan een norm de waarde van verschijnselen kan vergelijken. De norm functioneert als een waardestandaard.

Als twee verschijnselen met elkaar worden vergeleken, zijn soms de overeenkomsten overheersender dan de verschillen. In een samenleving kan veel commotie ontstaan rond historische vergelijkingen. KNIL-militairen vergelijken met SS-ers is hetzelfde als KNIL-militairen meten aan 
de waardeschaal waarmee SS-ers worden gemeten. Een politicus vergelijken met Hitler is de waarde van het handelen van de politicus meten met de standaard waarmee Hitler wordt gemeten. In de jaren tachtig ontstond in Duitsland een moreel en politiek geladen discussie over het al of niet unieke karakter van het duitse fascisme en over de toelaatbaarheid van historische vergelijkingen. Er was verzet tegen het feit dat Duitse historici het Nazisme hadden vergeleken met het Stalinisme en de wandaden van Pol Pot in Cambodja. In deze zgn. Historikerstreitging het in de kern om de vraag of zo'n vergelijking wel mocht, en wat de implicaties waren van een positief of negatief antwoord op die vraag.

Er is sprake van classificeren, als een onderzoeker elementen van de werkelijkheid verzamelt, en in die verzameling een bepaalde ordening aanbrengt aan de hand van een gegeven lijst van kenmerken. Het komt neer op inventariseren en systematiseren. Het beroemdste voorbeeld van dit type classificatie, is de ordening van de soorten levende wezens die de Zweedse bioloog Linnaeus in de achttiende eeuw opstelde.

Voorbeelden uit de geesteswetenschappen zijn er te over: museumcatalogi, lijsten met alle werken van een componist (men denke aan de beroemde Köchel-verzeichnis van alle werken van Mozart), concordanties (bijvoorbeeld de beroemde Trommius-concordantie: waarin men alle woorden vindt die in de Bijbel voorkomen met hun vindplaatsen), woordenboeken, etc. Het praktisch nut van zulke inventarissen behoeft geen betoog.

In de kunstgeschiedenis zijn belangrijke classificatiesystemen voor afbeeldingen en onderdelen daarvan tot ontwikkeling gekomen. Beroemd is het door de Nederlander Van de Waal ontworpen en door Couprie uitgewerkte systeem Iconclass. Het is niets anders dan een systematische manier van coderen van afbeeldingen en onderdelen daarvan. Als die codes op dezelfde systematische manier aan collecties schilderijen en prenten en literatuur daarover zouden worden toegekend, zouden op den duur in principe op een eenvoudige manier alle afbeeldingen die dezelfde voorstellingen tonen, bijeen kunnen worden gezocht. De Internetversie beschrijft de mogelijkheden als volgt:

At present the system contains approximately 24,00o definitions of objects, persons, events, situations and abstract ideas. With these definitions you can 'describe' the subjects of visual documents like paintings of old masters, book illuminations, or the photographs in your daily newspapers. 13,00o unique keywords help you locate the 
andere vormen van classificeren

ordening vereist concepten

het belang van de beschikbaarheid van concepten

narratologie

sommige wetenschappers onderzoeken concepten notations you need for describing or indexing your pictures. The $\mathrm{Bi}$ bliography contains some 40,0oo references to books and articles of iconographical and cultural historical interest.

Inmiddels zouden 350.000 kunstvoorwerpen met Iconclass gecodeerd zijn. Voor de iconografie, dat onderdeel van de kunstgeschiedenis dat zich bezighoudt met de voorstelling op kunstwerken, is Iconclass een belangrijk hulpmiddel.

Soms ligt er aan classificaties een rudimentaire theorie ten grondslag. Men denke aan de indeling van woordsoorten en zinsdelen zoals beschreven in de zogenoemde traditionele grammatica. De, het en een zijn lidwoorden. Naar, tot, bij, van, in, met etc. zijn voorzetsels. De basis voor dit onderscheid is al door Aristoteles gelegd. De ordening berust in eerste aanleg op intuïtief inzichtelijke verschillen en overeenkomsten tussen de verschijnselen. Het onderzoek is er op gericht aannemelijk te maken dat het onderscheid ook zichtbaar is te maken in andere verschijnselen. Dat de verschijnselen zich in de classificatie laten ordenen, is in eerste instantie dus het gevolg van een bepaalde manier van kijken. Maar die manier van kijken blijkt te werken als het begin van een theorie. Anders gezegd, het concept (het onderscheidende kenmerk) dat de ordening bepaalt, blijkt het denken te sturen.

Voor de ontwikkeling van de wetenschap is de beschikbaarheid van concepten van groot belang. We kunnen pas onderscheidingen maken als we over verschillende concepten (en woorden daarvoor) beschikken. Een nieuw concept maakt nieuwe waarnemingen mogelijk. Concepten vormen het mentaal waarnemingsinstrumentarium. Goede concepten richten de waarneming.

In de literatuurwetenschap is de afgelopen decennia een samenhangend geheel van concepten ontwikkeld waarmee een groot aantal aspecten van verhalen kan worden benoemd. Dit terrein staat bekend onder de naam narratologie. De verzameling is niet ten onrechte wel vergeleken met een grammatica, de verzameling taalkundige begrippen waarmee zinnen kunnen worden geanalyseerd. Net zoals de grammaticale begrippen zijn ook de narratologische niet theorie-neutraal.

Er zijn vakgebieden waar het onderzoek bepaald wordt door reflectie op bestaande concepten en stelsels van concepten, en op de reikwijdte en de geschiktheid van nieuwe. Men onderzoekt de beperkingen van het vertrouwde zicht op de werkelijkheid en de mogelijkheid van een nieuw perspectief. Dit type onderzoek is aanvankelijk in hoge mate beschouwend van aard. Conceptvorming vertegenwoordigt als het ware een fase in de ontwikkeling van wetenschap die vooraf gaat aan het empirisch onderzoek. 
vrouwenstudies als onderzoeksgebied van het dominante conceptuele systeem

strategieën voor verandering
$5 \cdot 4$

representaties van de werkelijkheid: een landkaart

een representatie van een (veranderings)proces: een model
Deze situatie lijkt op dit moment karakteristiek voor het onderzoek in de vrouwenstudies. Bij vrouwenstudies is de onvrede ontstaan door het idee dat de samenleving gedomineerd wordt door systemen van concepten die voortkomen uit een dominante mannelijke en westerse manier van kijken. Hier richt de conceptkritiek zich, zou men kunnen zeggen, op de conceptuele inhoud van de in de maatschappij dominante common sen$s e$. Een deel van het onderzoek in de vrouwenstudies heeft betrekking op het blootleggen van deze dominante common sense, en de uitwerking die dat heeft op de representatie ervan in cultuuruitingen. (Vgl. Buikema en Smelik 1993) Sommige onderzoeksters hebben de overtuiging dat men de wortels van de dominantieverhoudingen in een 'onderbewuste' moet zoeken. Zij zoeken daarom aansluiting bij een psychoanalytisch begrippenkader.

Een ander deel van het onderzoek in de vrouwenstudies is gericht op het bedenken van strategieën om de bestaande conceptuele systemen te bestrijden, of - op zijn minst - er niet het slachtoffer van te worden. Zulke strategieën zijn gebaat bij de vorming van nieuwe concepten waarmee zowel overeenkomsten tussen mensen, als hun verschillen kunnen worden gerepresenteerd, en die niet lijden onder de bestaande dominantieverhoudingen.

\section{Modellen}

Verklaren, begrijpen en classificeren zijn drie methodes die de geesteswetenschappen gebruiken om begrip te verwerven. Die drie soorten begripsverwerving komen bijeen in een vierde: sommige onderzoekers proberen een modelvan de werkelijkheid te ontwerpen. De wetenschapsfilosofen Apostel en Walry (1993:167) beschrijven het wetenschapsbedrijf zelfs als de 'collectieve en historisch doorgezette pogingen om modellen van delen van de werkelijkheid te construeren'.

Een model maken van de werkelijkheid is een oude en beproefde manier van kennisverwerving. De aardrijkskundigen produceren landkaarten, die een afbeelding zijn van aspecten van de werkelijkheid. Ze maken het mogelijk zich een overzicht te vormen over een relatief grote uitsnede uit de werkelijkheid. Men kan zeggen dat een landkaart het afgebeelde stuk van de werkelijkheid representeert. De kaart is een model van de werkelijkheid. Tekeningen en schema's zijn andere voorbeelden.

Het begrip 'model' is nog iets breder. Het wordt ook gebruikt voor een afbeelding van een werkelijkheid-in-verandering. Iets dat verandert, kun je niet zomaar afbeelden in het platte vlak. Je kunt er geen kaart van maken. Het idee van het model komt aan dit probleem tegemoet. Een model kan ook een representatie zijn van een aan veranderingen onderhevig 
modellen in de economische geschiedenis

modellen in de psycholinguïstiek stuk van de werkelijkheid. Het kan zowel betrekking hebben op een herhaalbaar gebeuren, als op een uniek gebeuren, dat in het model wordt gereconstrueerd.

Modellen zijn altijd simplificaties. Ze vereenvoudigen de werkelijkheid altijd tot die aspecten die kenbaar zijn. Een model wordt daar gebruikt waar de complexiteit van structuur en processen groot is, terwijl tegelijkertijd het een en ander bekend is over deelprocessen. In de economische wetenschappen zijn modellen populair. De interactie van een groot aantal bij een proces betrokken factoren kunnen in een model in een onderling verband geplaatst worden. Door de 'automatisering' heeft het gebruik van modellen in de wetenschap een hoge vlucht genomen.

De economisch-historicus Jan Luiten van Zanden (1985) heeft de modelgedachte toegepast door op basis van een sociologisch-economische theorie over 'kleine boeren' een model te construeren waaraan de historische verschijningsvorm van 'kleine boeren' in het Oost-Nederland van de negentiende eeuw wordt getoetst. Hier benadert het werken met een model 'het toetsen aan een norm', zoals dat in de vorige subparagraaf wordt beschreven. Uit het model worden voorspellingen over de (historische) werkelijkheid afgeleid, die vervolgens aan de historische werkelijkheid worden getoetst.

Bij de geesteswetenschappen wordt ook gewerkt met modellen bij de studie van de psychologische processen die een rol spelen bij taalgebruik. In het onderstaande citaat geeft taalpsycholoog De Ruiter aan wat de voordelen zijn van het werken met computermodellen.

Het belangrijkste [voordeel] is, dat men gedwongen is allerlei aannamen die in een theorie gedaan worden, nauwkeurig vast te leggen, waardoor deze ook voor iedereen inzichtelijk zijn. Dit betekent dat computermodellen vaak gemakkelijker te toetsen zijn dan verbale theorieën.

Een tweede voordeel is, dat een computermodel vaak voorspellingen doet die vanuit de leunstoel moeilijk te verzinnen of te overzien zijn. Een computermodel levert vaker nieuwe ideeën en voorspellingen op die tevens als leidraad kunnen fungeren voor verder onderzoek.

Niet te onderschatten is ook het belang van het scheppen van samenhang in de grote hoeveelheid bevindingen die in vakgebieden als cognitieve psychologie gepubliceerd worden. Als het lukt om een groot aantal bevindingen in een model te vangen, dan zijn deze bevindingen daarmee al voor een groot deel in een samenhangende theorie beschreven. Zo'n model moet natuurlijk wel iets toevoegen dat het op een computer draait is niet zaligmakend. Belangrijk is vooral dat het model niet alleen de gevonden data simuleert, maar deze op de een of andere manier ook verklaart. 
Een voorbeeld uit de psycholinguïstiek: als men weet dat veelgebruikte woorden sneller door mensen herkend worden dan weinig gebruikte woorden, heeft het weinig zin dit te simuleren door een programma te schrijven dat de herkenningstijd direct relateert aan een gebruiksfrequentie. In dat geval levert het model niets meer op dan we al wisten. Kan men echter een model maken dat woorden zo opslaat in een geheugen dat ze sneller gevonden worden naarmate ze vaker opgezocht zijn, dan is dat waardevol. Het geeft dan een verklaring voor bevindingen uit experimenten. [...] Samengevat: computermodellen zijn wezenlijk voor wetenschappelijke theorievorming. Zij brengen helderheid en samenhang in de grote hoeveelheid gegevens die door middel van experimenten aan het licht komen. (De Ruiter 1995)

is een model nieuwe kennis?

model biedt overzichtelijkheid

model heeft een heuristische functie

Poppers 'logica van de situatie'
Een model kan alleen maar vervaardigd worden als we er veel, zeer veel detailkennis en -vermoedens instoppen. Levert het model zelf ook nieuwe kennis op? Produceren we door een model te maken nieuwe kennis? Modellen hebben een enigszins hybride status. De volgende voordelen worden er in de literatuur aan toegekend.

Een model schept overzichtelijkheid in een verwarrende hoeveelheid gegevens en deelprocessen. Denk nog eens aan de landkaart. Een landkaart is in de eerste plaats een 'afbeelding', een 'representatie' van de kennis over de werkelijkheid die we al hadden. Anders hadden we de landkaart niet kunnen vervaardigen. Maar vanwege de nieuwe overzichtelijkheid kunnen uit deze representatie wellicht nieuwe hypotheses over de werkelijkheid voortkomen en die zijn mogelijk een bron van nieuwe kennis. Zo is dat ook het geval bij modellen. Door de nieuwe overzichtelijkheid is de heuristische functie de meerwaarde die een model heeft: het stuurt het zoeken van de onderzoeker.

We spraken in het voorgaande over 'modellen' als mogelijke uitkomsten van (geesteswetenschappelijk) onderzoek. Verwant aan deze modellen is een benadering die Popper schetste en die in de wetenschapstheoretische literatuur bekend staat als de 'Situationslogik'; te vertalen met 'logica van de situatie'. Popper beschrijft dit na te streven onderzoeksresultaat als volgt.

[...] we may say that our actions are to a very large extent explicable in terms of the situation in which they occur. Of course, they are never fully explicable in terms of the situation alone; an explanation of the way in which a man, when crossing a street, dodges the cars which move on it may go beyond the situation, and may refer to his motives, to an 'instinct' of self-preservation, or to his wish to avoid pain, etc. But this 'psychological' part of the explanation is very often trivial, as 
compared with the detailed determination of his action by what we may call the logic of the situation [...]. (Popper 1985:353)

logica van de situatie: alle situationele gegevens als input en het feitelijk gedrag als output

handelende persoon als probleemoplossers
Wat Popper bedoelt is dus ongeveer het volgende. Tot de situatie waarin 'gedrag' tot stand komt, behoren een hele reeks uiterlijke omstandigheden. Daarnaast gaat er nog allerlei in het hoofd van iemand om, maar de kennis daaromtrent is onbetrouwbaar. Nemen we nu aan dat alle actoren zich altijd rationeel gedragen. Dan is de constructie van een logische relatie tussen alle uiterlijke omstandigheden voldoende om het gedrag te verklaren. De redenering is het rationeel geconstrueerde verband tussen situatie en feitelijk gedrag.

Zo gezien is de Nachtwacht de oplossing van Rembrandts probleem een schilderij te maken dat aan bepaalde voorwaarden moest voldoen: de verlangens van zijn opdrachtgevers, de eisen die de cultuur aan een dergelijk schilderij stelde, de mogelijkheden die de schildertechniek hem liet, Rembrandts eigen schilderkunstige opvattingen, etc. Men kan zeggen dat het een kunsthistorische opgave is Rembrandts probleem zo te reconstrueren dat de Nachtwacht er de logische oplossing voor is. Die reconstructie is rationele, in principe verbeterbare kennis.

Popper beschrijft een werkwijze die we in de geschiedbeoefening en het onderzoek van de kunsten veelvuldig aantreffen. Een mooie toepassing vinden we in Hélène Nolthenius' studie over het leven van Franciscus van Assisi De man uit het dal van Spoleto (Nolthenius 1989). Eerst presenteert de schrijfster daarin een grote reeks citaten uit contemporaine bronnen om de tijd van Franciscus te schetsen, het Midden-Italië van de twaalfde, dertiende eeuw. Daarna presenteert ze een geordende reeks citaten, eveneens uit bronnen uit die tijd waarin Franciscus wordt beschreven of over Franciscus wordt gesproken. Ten slotte ordent ze deze gegevens tot een samenhangend beeld van Franciscus en de door hem geïnspireerde religieuze beweging. In die ordening probeert de schrijfster recht te doen aan alle gegevens uit die tijd.

Voordelen en nadelen van situatie-logische verklaringen worden door Popper als volgt tegen elkaar afgewogen. Het anti-psychologistische standpunt van de wetenschapstheoreticus krijgt daarin het volle pond.

[...] admittedly, I have different aims and I hold different theories (from, say, Charlemagne); but had I been placed in his situation thus analysed - where the situation includes goals and knowledge - then I, and presumably you too, would have done what he did. The method of situational analysis is certainly an individualistic method and yet is certainly not a psychological one; for it excludes, in principle, all psychological elements and replaces them with objective situational 
het rationaliteitsprincipe toegelicht elements.[...] The explanations of situational logic described here are rational, theoretical reconstructions. They are oversimplified and overschematized and consequently in general false. Nevertheless, they can possess a considerable truth content and they can, in the strictly logical sense, be good approximations to the truth, and even better than other testable explanations. [...] Above all, however, situational analyses are rational, empirically criticizable and capable of improvement. For we may, for instance, find a letter which shows that the knowledge at Charlemagne's disposal was completely different from what we assumed in our analysis. By contrast, psychological or characterological hypotheses are hardly ever criticizable. (Popper 1992: 79-80)

Het onderzoeksresultaat is een betoog. Voorzover de redeneringen er in sluitend zijn, is het betoog een logisch model van de gedragssituatie. In het model wordt geen beroep gedaan op elementen in de geest van de handelende persoon, die door inleving zijn vastgesteld. Het leent zich voor rationele en empirische toetsing. Het is van belang op te merken dat er in het model common sense-verklaringen ingevoerd moeten worden om de redenering sluitend te krijgen. In het bovenstaande citaat gaat Popper daaraan voorbij.

Het 'rationaliteitsprincipe', de veronderstelling dat mensen in de gegeven situatie rationeel handelen, speelt in Poppers 'Situationslogik' een belangrijke rol. In het volgende citaat licht hij de werking van dit principe nog wat toe.

It is interesting to see that we employ the rationality principle to the limit of what is possible whenever we try to understand an action, even the action of a madman. We try to explain a madman's action, as far as possible, by his aims (which may be monomaniac) and by the 'information' on which he acts, that is to say, by his convictions (which may be obsessions, that is, false theories so tenaciously held that they become practically incorrigible). In so explaining the actions of a madman we explain them in terms of our wider knowledge of a problem situation which comprises his own, narrower, view of his problem situation; and understanding his actions means seeing their adequacy according to his view - his madly mistaken view - of the problem situation. (Popper 1985:362-363)

Poppers idee is dat onderzoekers van het menselijk gedrag op de aangegeven wijze kunnen ontkomen aan de valkuilen van het 'psychologiserend inleven', dat, zoals we gezien hebben, soms als het eigenlijke Verstehen wordt beschouwd. 
Het rationaliteitsprincipe fungeert als een weliswaar aantoonbaar werkelijkheidvervormend, maar desondanks handig principe. Als we een voorgestelde analyse van een situatie onder kritiek stellen en verbeterbaar achten, kunnen we beter zoeken naar de waarneembare elementen in de omstandigheden dan naar de in principe onkenbare psychische processen van de handelende persoon. Als er een veelheid aan intenties van gedrag denkbaar is, kunnen we een beroep doen op coherentie om een keuze te maken.

\section{5}

bij wijze van samenvatting

'... en wat heeft dat nu met waarheid te maken?'

\section{Wetenschap en waarheid}

Waar heeft dit hoofdstuk ons gebracht? We hebben geprobeerd te laten zien op welke manieren onderzoekers de triviale werkelijkheid gebruiken om kennis te produceren. We hebben dat proberen af te leiden uit een aantal voorbeelden van wetenschappelijk werk, en uit uitlatingen van wetenschappers daaromtrent. Dat leverde het volgende beeld op.

Min of meer afhankelijk van de mogelijkheden die hun onderzoeksobjecten bieden zoeken wetenschappers naar uitbreiding van hun kennis. Soms zoeken ze het in de diepte, soms in de breedte, soms ook gaat het om combinaties van beide strategieën. Dit alles geschiedt met een zo groot mogelijke rationaliteit als inzet: hoe de redeneringen ook zijn opgezet, hoe breed of diep de inzichten ook worden gezocht, altijd is de logische geldigheid ervan en de verankering in de empirische werkelijkheid het richtsnoer waaraan wordt vastgehouden. Altijd is er ook de inzet om het kennend subject buiten de redenering te houden.

En dan is er ten slotte de onontkoombare vraag: 'komen de wetenschappers zo dichter bij de waarheid? Denken ze dat ze door naar verklaringen en interpretaties te zoeken, door modellen en classificaties op te stellen uiteindelijk bij de waarheid uitkomen?'

In de voorgaande hoofdstukken hebben we er al op gewezen dat de wetenschap een dubbelzinnige houding aanneemt tegenover de waarheid. Aan de ene kant is de wetenschap bezeten door de zucht de waarheid te kennen, en worden in het onderzoek allerlei maatregelen genomen om de onwaarheid buiten te sluiten; en aan de andere kant zijn er weinig wetenschappers die voor hun inzichten het woord 'waarheid' in de mond durven nemen. De meeste wetenschappers zijn 'fallibilist', ze hechten eraan zichzelf feilbaar te achten. Het begrip waarheid, zo ze daar al over spreken, is gereserveerd voor onmiddellijk door observatie vast te stellen, op zichzelf weinig opzienbarende trivialiteiten. En dan nog gaat het daar eerder om een weten dat we voor waar aannemen omdat iedereen het met ons eens is, niet omdat er een onomstotelijke correspondentie tussen bewering en werkelijkheid is vastgesteld. Het is een waarheid, 
omdat we onder zekere condities met elkaar afspreken dat het de waarheid is.

andere beperkingen op de mogelijkheid de waarheid te vinden
We hebben sindsdien van verschillende kanten verder bevestigd gezien dat de waarheid eigenlijk steeds buiten het bereik van de onderzoekers blijft. We noemen nog een paar punten die in dit opzicht van belang zijn gebleken.

- de afstand tussen de werkelijkheid en de door de beschikbaarheid van concepten gestuurde waarneming van de werkelijkheid;

- de afstand tussen directe observatie en de verwoording van die observatie;

- het inductieprobleem; verificatie van kennis, dat wil zeggen bewijzen dat een theorie waar is, door systematisch alle gevallen in de werkelijkheid die door de theorie worden 'gecoverd', te toetsen, is onmogelijk;

- waarnemingsinstrumenten hebben noodzakelijkerwijs een theoretische component: de oscillograaf die een geluid zichtbaar maakt, verandert iets aan de wijze waarop we het geluid waarnemen;

- de onmogelijkheid om de waargenomen werkelijkheid onbeperkt op te delen in kleine stukjes zonder de werkelijkheid te denatureren.

Ondanks al deze belemmeringen om de waarheid te kennen lijken onderzoekers zich toch als waarheidzoekers te gedragen. Er bestaat zoiets als de waarheid, zo lijken ze te denken, maar dat wil nog niet zeggen dat er ooit meer dan een voorlopige waarheid binnen handbereik ligt.

De dubbelzinnige houding ten opzichte van de waarheid is alleen maar goed te begrijpen in het licht van het idee dat de wetenschap vooruitgaat. Over de groei van kennis spreken we in het zevende hoofdstuk. In het volgende hoofdstuk staan we eerst nog stil bij een controverse over de bruikbaarheid van het begrip 'coherentie' als maat voor succes in het wetenschappelijk onderzoek. 


\section{6}

coherentie en correspondentie

coherentie favoriet

correspondentie favoriet

\section{Coherentie}

In een voorgaand hoofdstuk hebben we opgemerkt dat wetenschappen die kennis produceren in de vorm van 'tekst' de samenhang van de tekst als maat van succes hanteren. In dit hoofdstuk gaan we in op het fundamentele wetenschapstheoretische belang van de notie 'samenhang'. De termen 'coherentie', 'samenhang' en 'cohesie' zullen we door elkaar gebruiken.

In het voorgaande maakten we kennis met twee 'waarheidstheorieën': de correspondentietheorie en de coherentietheorie. Volgens de correspondentietheorie van waarheid is een uitspraak waar als deze correspondeert met de werkelijkheid, met de feiten. Daartegenover staat de coherentietheorie van waarheid die zegt dat een uitspraak waar is wanneer zij samenhangt met een aantal andere uitspraken die we al als waar hebben aanvaard.

[Volgens de coherentietheorie is een uitspraak waar], wanneer deze past in het geheel van reeds geaccepteerde uitspraken, dat door deze toevoeging zijn coherentie niet verliest, maar behoudt of versterkt.

(De Vries 1985: 80)

De theoretisch-historicus Lorenz (1987) meent dat historici waarschijnlijk het meest voor de coherentietheorie zullen voelen. Zijn vakgenoot Van der Dussen (1988) noemt de coherentietheorie 'veel aannemelijker' dan de correspondentietheorie 'ten aanzien van uitspraken over het verleden'. Voorstanders van de coherentietheorie illustreren deze ook vaak met historische voorbeelden.

Coherentie is echter een omstreden begrip. De meeste beoefenaren van een empirische wetenschap onderschrijven impliciet of expliciet de correspondentietheorie. Filosofen zijn de belangrijkste getuigen. De filosoof Putnam zegt bijvoorbeeld: 'The theory that truth is correspondence is certainly the natural one. Before Kant it is perhaps impossible to find any philosopher who did not have a correspondence theory of truth.' (1981: 56) En de filosoof Kirkham, die een vergelijkende studie maakte van de belangrijkste waarheidstheorieën, beweert: 'The chief weakness of the coherence theory of truth is its lack of initial plausibility.' (1992: 110) De oordelen van geschiedtheoretici zijn hier wel op een bijzondere wijze mee in strijd. 
historici doen vaak een beroep op samenhang zijn correspondentietheorie en coherentietheorie verenigbaar?
Het probleem is gedeeltelijk terminologisch. Kirkham maakt een onderscheid tussen coherentietheorieën-van-waarheid en coherentietheorieën-van-rechtvaardiging; en het is, althans uit Lorenz' uiteenzettingen, duidelijk, dat wat hij, Lorenz, een coherentietheorie-van-waarheid noemt eigenlijk een coherentietheorie-van-rechtvaardiging is. Maar ook als we dit verdisconteren, blijft er een groot verschil in appreciatie van coherentie als maat voor wetenschappelijk succes.

In het gesignaleerde verschil van inzicht lijken Van der Dussen en Lorenz de praktijk van historici aan hun zijde te hebben. Historici beroepen zich regelmatig op samenhang om een opvatting aannemelijk te maken. Befaamd is de passage in het werk van Huizinga waar hij spreekt over 'het historisch kennen', dat altijd 'een verstaan van samenhang' is, welke samenhang hij vergelijkt met een boeket, 'een los samengebonden bundel'. Vergelijk ook de volgende citaten van de historicus Martin:

On the basis of [...] our so-called evidence, we have to piece together a coherent account of what must have happened. (1993: 29)

We seek explanations for the meaning of historical episodes (but not only) when we are puzzled because something doesn't 'fit'. We want a more coherent understanding. [...] We demand that historical accounts render the past intelligible - the more intelligible the better. This involves, as I suggested, fitting what we know about individual historical episodes into a coherent context, so that we are not puzzled by what we think was going on. (1993: 43-44)

Deze citaten kunnen gemakkelijk met zeer veel anderen worden uitgebreid.

Hier is dus een probleem. Het is niet aannemelijk dat historici in de praktijk gebruik maken van een concept dat een plaats vindt in een implausibele theorie. We moeten derhalve deze praktijk verder onderzoeken om te achterhalen waarom historici vertrouwen hebben in cohesie als maat voor succes en of de correspondentie- en coherentietheorieën verenigbaar zijn.

De noties waarvan hier sprake is, coherentie, cohesie, samenhang, vindt men gebruikt bij het beoordelen van interpretaties. Onderzoekers zijn tevreden over een interpretatie naarmate ze meer elementen van een te interpreteren geheel met elkaar in verband brengen. Daar zullen we nu eerst bij aanknopen. We kiezen als voorbeeld een interpretatie van een schilderij. 
een voorbeeld van het

gebruik van

coherentie als maat

van wetenschappelijk

succes: De Jongh en

Vinken over Hals'

'Echtpaar ten voeten uit'
De Jongh en Vinken publiceerden in 1961 een iconologische studie van het schilderij 'Echtpaar ten voeten uit' van Frans Hals in het Rijksmuseum in Amsterdam. Op dit schilderij is een wijnrank zichtbaar

welke [...] de boom omstrengelt achter en precies tussen de hoofden van de man en de vrouw in. In dit detail [...] wordt de huwelijksrelatie op allegorisch niveau weerspiegeld; hier wordt niets anders geafficheerd dan een in de 16e en 17e eeuw bekend beeld dat in de emblemata-literatuur en in de amoureuze poëzie van die tijd regelmatig optreedt.

In een voetnoot bij deze zin merken De Jongh en Vinken op dat de wijnstok of wijnrank een symbool is van

vele andere begrippen: van de vruchtbaarheid, van Christus en Maria, van Bacchus en de Herfst, van Europa, van het dichterschap, etc.

Kennelijk achten zij die betekenissen hier niet aan de orde.

De eveneens op het schilderij voorkomende distel associëren de auteurs met de 'meer seksuele aspecten van de erotiek'. Ook de distel kent nog een aantal andere uiteenlopende betekenissen, zoals aanduiding van nijd, haat, wraak, ketterij, zonde, beeld van aardse smarten, van martelaarschap, etc. Ook die worden door de auteurs voor de distel op dit schilderij niet relevant geacht. De genoemde interpretatiemogelijkheden van wijnrank en distel worden door de auteurs met citaten uit zeventiendeeeuwse bronnen ondersteund. We kunnen daarom zeggen dat ieder van de interpretatiemogelijkheden in principe correspondeert met de historische bronnen. Die bronnen zijn veelal embleemboeken, verzamelingen literaire en picturale zinnebeelden, plaatjes met een vermaning in versvorm of proza of beide. De bronnen noemen met zoveel woorden een distel een zinnebeeld van seks of van ketterij of van martelaarschap etc. Een voorbeeld van zo'n bron zouden de beide strofen uit Ariosto's Orlando Furioso kunnen zijn die hierbij gaan.

van alle mogelijke interpretaties is er eén favoriet
De auteurs van de studie over het schilderij van Hals kiezen dus uit de gepresenteerde reeksen steeds één bepaalde betekenis. Bij die keuze worden ze maar door één overweging geleid en dat is de samenhang die de gekozen betekenis oplevert met de andere interpretatieve elementen waaruit het schilderij is opgebouwd: de zichtbare, de gelukkig lachende man en vrouw bijvoorbeeld, en de onzichtbare, het abstracte begrip waar wijnrank en distel naar verwijzen. Weliswaar heeft de wijnrank die een olm omstrengelt - zo is de impliciete redenering - ook een betekenis Christus en Maria, maar die betekenis past niet bij de andere elementen van het schilderij en hun interpretatie. De manier waarop de man en de 


\section{Twee strofen uit Orlando Furioso}

Canto 7:29

Zo innig heeft een klimop zich nog zelden

Gestrengeld om de plant die naast hem stond

Als zij het deden in hun liefdesspel, de

bezielde lippen op elkanders mond,

Een zoeter bloem dan men op verre velden

Van 't vruchtbare Arabië ooit vond.

Die vreugd wordt door henzelf het best bezongen,

Omdat hun mond gevuld werd door twee tongen.

\section{Canto 10:9}

Wil, vrouwen, mijn verzekering aanvaarden

Dat ik u't minnen niet verbied, want dan

Bent u gelijk een wijnrank in de gaarde

Die op geen tak of latwerk steunen kan.

Maar hoed u voor de met jong dons bebaarde,

Dus wispelturige, ontrouwe man!

Wees voor onrijp en steenhard fruit beducht en

Kies rijpe, maar niet al te rijpe vruchten.

In beide strofen wordt de verliefde met een slingerende plant vergeleken die steun zoekt bij een andere plant, tak of latwerk. Orlando Furioso ('Razende Roeland') van Ludovico Ariosto uit 1532 was een van de populairste verhalen uit de zestiende eeuw. (Vertaling Ike Cialona)

vrouw zijn afgebeeld correspondeert in kleding, houding, gelaatsuitdrukking etc. niet met de gebruikelijke voorstellingswijze van Christus en Maria - en dus betekent de een olm omstrengelende wijnrank in de context van dit schilderij niet 'Christus en Maria'.

Omgekeerd, omdat de interpretatie: 'de wijnrank verbeeldt een echtelijke relatie', wel past in het schilderij dat een gelukkig lachende man en vrouw als echtpaar uitbeeldt, is die interpretatie juist, en wordt de bewering: 'de wijnrank verbeeldt in dit schilderij de huwelijksrelatie' waar. Iets dergelijks geldt mutatis mutandis ook voor de gekozen interpretatie van de distel. Daar past eveneens maar een van de mogelijk geachte interpretaties. Uiteindelijk kunnen de auteurs dan ook concluderen: 'De zinnebeeldige elementen zijn volledig in het realistische tafereel geïntegreerd.' (1961: 137) 
samenhang rechtvaardigt de keuze van een favoriete interpretatie

hineininterpretieren

correspondentie en coherentie spelen allebei een rol

de hermeneutische cirkel

werkt coherentie in de geschiedenis ook zo?
Wat de analyse van dit voorbeeld aan het licht brengt, is dat cohesie een argument is om een keuze voor een zekere interpretatie te rechtvaardigen. De wijnrank en distel zijn op zichzelf in de emblematische traditie meerduidig en de samenhang beslist over de betekenis die in het verband van het geïnterpreteerde schilderij relevant is. Dat is bij nader inzien niks bijzonders: denk aan woorden in een zin. Op zichzelf beschouwd soms dubbelzinnig, verliezen woorden die dubbelzinnigheid meestal door het zinsverband.

Natuurlijk komt het voor dat er onderzoekers zijn die samenhang menen gevonden te hebben, als er te weinig correspondentie met de werkelijkheid kan worden aangetoond. Men spreekt dan van 'hineininterpretieren'. Laten we aannemen dat dat hier niet zo is. We hebben nu het volgende. Er zijn onafhankelijke argumenten voor de opvatting dat huwelijksrelatie en erotiek een mogelijke betekenis is van wijnrank en distel. De bronnen, de bewijsplaatsen in de literatuur leveren deze argumenten. De mogelijke betekenissen waren dus al potentieel correct op grond van deze bewijsplaatsen. Buiten de context is tot een mogelijke juistheid te besluiten, en wel op grond van de correspondentie van deze betekenis met een vermelding elders. In de context wordt de virtuele correctheid een definitieve: de andere, eveneens (virtueel) correcte, maar niet passende interpretaties vallen af. De interpretatie die op grond van de samenhang wel wordt verkozen, past in een groter geheel en versterkt daarmee de juistheid van de interpretatie van het totaal. De praktijk van het kunsthistorisch interpreteren levert dus een voorbeeld van de veronderstelde werking van de coherentietheorie.

We stuiten weer op de hermeneutische cirkel die we al eerder zijn tegengekomen. Het interpretatieproces voert ons in een pendelbeweging van detail naar totaal, en weer terug. De interpretatie komt tot stand door een samenhang van beweringen te creëren die het mogelijk maakt een onderdeel te begrijpen door dit in de samenhang te integreren.

Ongeacht de vraag of de interpretatie van De Jongh en Vinken juist is, achten we het voorbeeld illustratief voor een redeneerwijze waarmee onderzoekers een interpretatie onderbouwen. In voorgaande hoofdstukken hebben we impliciet al twee keer eerder een demonstratie van de coherentietheorie gegeven. Bij de waarneming van de gele vlek in de tuin maakten we een keuze uit mogelijke interpretaties: narcis, verkreukeld servetje, ballonrestant. En de interpretatie van de ondertekening van de brief aan Richard Wagner was eveneens gebaseerd op een keuze uit mogelijke interpretaties.

Werkt de coherentietheorie in een historische bewijsvoering net zo? De kennis die de historicus zoekt, heeft nogal eens, zo niet altijd, de vorm van een algemene interpretatieve bewering, die het toevallige van de feiten een betekenis beoogt te geven in een groter verband. De volgende 


\section{Semiotiek}

Achter op de auto van mijn buurman staat I⿶NY.

Iedereen weet wat dat betekent. Mijn buurman houdt van New York. Een boodschap als deze is niet helemaal taal, en niet helemaal voorstelling, maar heeft iets van allebei. De vier elementen ervan zijn tekens. De semiotiek is het vakgebied dat het gebruik van tekens analyseert van welke aard dan ook.

Tekens komen overal voor. In taal natuurlijk, maar ook in gedrag ('handopsteken'), op de openbare weg ('verkeersborden'), in het sociale verkeer ('ansichtkaarten'; 'rouwannonces'), in de religie ('kruisbeelden'), in de politiek ('roos in de vuist'), in de beeldende kunst. Als je het goed beschouwt, kan alles wel teken zijn. Lipstick aan een glas kan al een teken van medeplichtigheid zijn. Een gefluisterd woord een teken van samenzwering.

Waar woorden bijna steeds een willekeurige relatie hebben tussen vorm en betekenis, is de interpretatie bij andere tekens vaak af te leiden uit de vorm (een landkaart lijkt op het afgebeelde land) of staat er volgens common sense mee in een causale relatie of allebei (' $\boldsymbol{\nabla}$ ' = 'een hart' = 'zetel van liefde' = 'love'). Tekens, hun betekenis en de context waarin ze werken, worden geleerd, net als woorden.

De semiotiek claimt verborgen betekenissen te kunnen opsporen. In de roman Nice Work van David Lodge komt een hilarische discussie voor tussen een literatuurwetenschapster en een fabrieksdirecteur over een billboard waarop een paarse zijden lap is afgebeeld met een snee erin. De afbeelding dient als een woordeloze reclame voor het sigarettenmerk Silk Cut. De literatuurwetenschapster meent dat

[the] shimmering silk, with its voluptuous curves and sensuous texture, obviously symbolized the female body, and the elliptical slit, foregrounded by a lighter color showing through, was still more obviously a vagina. The advert thus appealed to both sensual and sadistic impulses, the desire to mutilate as well as penetrate the female body.

Haar metgezel noemt dit flauwekul. Wie heeft er gelijk?

Het is hier niet duidelijk wat de empirische basis van verborgen betekenissen is, behalve de bias dat waarnemingen moeten passen in een freudiaans kader. Er bestaat niet zoiets als een algemeen 'tekenboek', waar alle tekens van onze cultuur met hun standaardbetekenissen in staan, zoals er een algemeen woordenboek of embleemboeken bestaan.

Bronnen: Aart van Zoest, Semiotiek. Over tekens, hoe ze werken en wat we ermee doen; Arie J. Gelderblom, 'Ceci n'est pas une pipe. Kunstgeschiedenis en semiotiek' in Halbertsma en Zijlmans (1993). 
eenvoudige historische redenering, in essentie gebaseerd op Van der Woude (1972) en Davids (1993), kan dat toelichten.

een eenvoudige historische redenering

correspondentie...

... en coherentie zijn relevant voor de juistheid van de redenering
De opmerkelijke Nederlandse welvaart in de Gouden Eeuw had een technisch-industriële basis. Nederland liep bij de bouw van schepen namelijk voor op de rest van de wereld. Vooral dankzij twee innovaties: men slaagde er in een standaard-vrachtschip, de fluyt, te ontwikkelen; en er kwam een molentype tot ontwikkeling waarmee snel planken gezaagd konden worden...

Het ontstaan van molentype en scheepstype kunnen worden gedocumenteerd. In archieven bevinden zich documenten waarin de bouw van molens en van schepen van de bedoelde nieuwe types wordt beschreven. De uitvinding van de molen staat op naam van Cornelis Cornelisz, en werd voor het eerst toegepast in Uitgeest. Die van de fluyt is van 1595 en staat op naam van Pieter Jansz. Liorne uit Hoorn. Feitelijke uitgangspunten in de redenering vertonen dus de vereiste correspondentie met de werkelijkheid.

De bouw van een reeks houtzaagmolens wordt niet als een reeks losstaande historische feitjes gezien, maar als een ontwikkeling. De bouw van de houtzaagmolens wordt geïnterpreteerd als een feit dat relevant is voor de scheepsbouw. De bouw van houtzaagmolens is coherent met het bestaan van een gedocumenteerde behoefte aan hout in de scheepsbouw. Dat de bouw van de molens in de feiten over de scheepsbouw past, versterkt het gelijk van de voorgestelde interpretatie. Het is niet onaannemelijk dat er nog andere interpretaties van de bouw van houtzaagmolens bestaan - nieuwe bron van inkomsten, verandering van het landschap, etc. - maar die versterken de samenhang niet, en doen in de redenering dus niet mee. Deze redeneerwijze kan met enig recht een model genoemd worden voor de praktijk van het historisch redeneren.

In deze reconstructie van het historisch redeneren is verondersteld dat een bewering die correspondeert met een zekere gebeurtenis een reeks van interpretaties toelaat. Hoe komen we aan die interpretaties? Een belangrijke bron is onze common sense. Onze algemene kennis van de wereld zegt ons dat het min of meer gelijktijdig bouwen van een aantal molens van hetzelfde type niet als een verzameling losstaande feiten moet worden gezien, maar als aspecten van een en dezelfde ontwikkeling.

Ook die interpretaties zijn dus mogelijk correct voorzover ze zich laten afleiden uit de feiten en algemene kennis van de wereld. Een status van feitelijkheid verkrijgen ze zodra ze blijken te kunnen worden ingepast in een algemenere bewering. De betekenistoekenning, de zingeving, dit Verstehen, is derhalve een keuze uit mogelijk correcte interpretaties op grond van een algemene bewering waarin die interpretatie past. 
wordt coherentie in de kunstgeschiedenis op dezelfde manier gebruikt als bij de geschiedbeoefening?

een belangrijk verschil: artefacten en menselijk gedrag kennen een zekere ordening...

... voor historische gebeurtenissen is dat lang niet altijd duidelijk

verheldert dit de controverse tussen filosofen en theoretisch-historici over de waarde van coherentie?
Het bovenstaande laat zien dat de toepassing van de notie 'samenhang' in een historisch betoog tot op grote hoogte parallel loopt met de toepassing ervan bij de interpretatie van een schilderij in de iconologische traditie.

Maar er is ook een belangrijk verschil. Aan de iconologische interpretatie van een schilderij als 'Echtpaar ten voeten uit' ligt enerzijds het triviale gegeven ten grondslag dat de te interpreteren werkelijkheid beperkt is: alle samenhangende elementen bevinden zich binnen de lijst van het schilderij. Anderzijds is er de veronderstelling dat de werkelijkheid van het schilderij een geordende is, waarin alle elementen (van een zekere omvang en eindig in aantal) met elkaar verband houden. Deze veronderstelling speelt bij de interpretatie van kunstwerken en teksten een rol. De menselijke geest kan door mensen vervaardigde dingen niet interpreteren zonder ervan uit te gaan dat de delen ervan met elkaar in verband staan. Hetzelfde geldt voor reeksen van gedragingen van hetzelfde individu of van individuen die in hun gedrag op elkaar reageren. Onweerstaanbaar werkt de behoefte in ons om bij de waarneming te zoeken naar wat de onderdelen samenbindt. Wie naar samenhang zoekt, gaat uit van de veronderstelling dat de werkelijkheid binnen zekere grenzen niet chaotisch is. Dit is natuurlijk ook in het historisch bedrijf niet een onbekende gedachte.

Een probleem is echter dat er met betrekking tot de loop van de geschiedenis geen onafhankelijke evidentie is voor zo'n geordendheid. De toepassing door Cornelis Cornelisz van een of ander nieuw principe in een molen in Uitgeest heeft weliswaar een interpretatie die de bewering coherent maakt met een algemene bewering over de ontwikkeling van de houtzaagmolen in de zestiende en zeventiende eeuw. Maar daarmee is de noodzaak van deze interpretatie niet aangetoond. Hoe weten we dat de bouw van een willekeurige molen in een andere plaats, b.v. Zaandam in die tijd niet los van de ontwikkeling van de houtzaagmolen moet worden gezien? Er is geen mogelijkheid om te bepalen welke elementen wel en welke niet met een bepaalde ontwikkeling een samenhang vertonen. Toen we in paragraaf 4.1.3 spraken over manipulatie van onderzoeksobjecten hebben we er op gewezen dat er om samenhangende delen van de geschiedenis geen lijst staat zoals een schilderij een lijst heeft, waarbinnen alle elementen in samenhang zijn; geen begin en eind zoals een tekst waarvan de woorden en zinnen met elkaar in verband staan.

Terug daarom nu naar het begin, en naar de vraag hoe het mogelijk is dat de waardering van cohesie als kentheoretische term zo uiteen kan lopen als aan het begin van dit hoofdstuk het geval bleek? Hoe is het mogelijk dat een epistemoloog als Kirkham enerzijds, en historici en theoretisch-historici anderzijds coherentie kentheoretisch zo anders waarderen? 
de vertrouwdheid van

de geestesweten-

schappen met een

ambigue werke-

lijkheid
Het punt waarop de opinies uiteenlopen, is het antwoord op de vraag of en zo ja hoe 'coherentie' iets aan de juistheid van een bewering kan toevoegen. Kirkham heeft ongetwijfeld gelijk in zijn zienswijze dat de gerechtvaardigdheid van beweringen niet toeneemt door cohesie, als de juistheid ervan al het resultaat is van waarneming of van een geldige redenering. Van zijn kant heeft Lorenz gelijk in zijn zienswijze dat historici terecht een beroep op coherentie kunnen doen als rechtvaardigingsgrond voor de juistheid van hun beweringen. Hoe kunnen deze standpunten worden verzoend?

We hebben in het bovenstaande laten zien dat coherentie een grond is om uit een aantal interpretaties te kiezen. Het vaststellen van samenhang is een manier om een ambigue werkelijkheid te disambigueren. Coherentie rechtvaardigt geen beweringen, maar een keuze uit een reeks interpretaties. Coherentietheorieën controleren de waarheid niet; ze wijzen een uitweg, als correspondentie slechts als mogelijkheid, niet als feit kan worden vastgesteld.

Als de historicus de kans krijgt, zal correspondentie met de empirische werkelijkheid, verantwoord in de voetnoten, zoals we al eerder hebben opgemerkt, een superieure bron van kennis worden gevonden. Voor de rechtvaardiging van kennis is correspondentie met de werkelijkheid nu eenmaal superieur aan coherentie met een reeks andere beweringen. Waar we echter niet aan mogen voorbijgaan is de mogelijkheid dat we in een en hetzelfde verschijnsel twee of meer verschillende dingen kunnen zien. Een filosoof als Kirkham heeft daar geen aandacht voor. Voor historici en voor geesteswetenschappers in het algemeen is dit echter een zeer vertrouwde gedachte. In de theorie van de geschiedenis (en in de theorie van andere wetenschappen) moet naast een correspondentietheorie plaats zijn voor een coherentietheorie, niet omdat de laatste aantrekkelijk zou zijn, maar omdat ons waarnemingsvermogen soms een dubbelzinnig beeld oplevert. We hebben een coherentietheorie nodig als we willen verantwoorden hoe we rationeel tegemoet kunnen komen aan onze onstelpbare behoefte om ook een dubbelzinnige werkelijkheid te begrijpen.

En dan is er soms de overmoed van 'het grote verband'. In een artikel in de catalogus bij een tentoonstelling van zeventiende-eeuwse landschapsschilderijen schrijft de historicus Simon Schama:

Three great transformations occurred in the Northern Netherlands between 1590 and 1650. A type of landscape painting, wholly new to Western art, made its first appearance; the physical geography of northern Holland was dramatically altered by the reclamation of about two hundred thousand acres from inland seas; and the United Provinces detached itself from the body of international monarchy 
Simon Schama's

vormen van

'landwinning' and became, rather suddenly, a self-conscious, independent, culture. The contemporaneity of these developments was not accidental. They were related in complicated and indirect ways that preclude any one of the phenomena 'explaining' the other. But that there was some connection between the peculiarities of Dutch geography and history and the revolutionary peculiarities of its landscape painting between 1620 and 1640 is very likely. (Schama 1987: 64)

De verleiding om tussen gelijktijdige ontwikkelingen een samenhang te construeren is voor sommigen soms te groot. In een betoog als dat van Schama heeft een serieuze coherentietheorie niets te zoeken. Hier geen dubbelzinnige werkelijkheid die ontdubbelzinnigd wordt door een interpretatie in te passen in een reeks andere kenniselementen. Hier de speculatie dat de gelijktijdigheid geen toeval kan zijn, maar 'very likely' een causale relatie verbergt. Theorieën die een 'samenhang' tussen maatschappelijke ontwikkelingen kunnen verklaren, doen op een of andere manier altijd een beroep op een wetmatigheid in de loop van de geschiedenis. Ze doen een beroep op een 'tijdgeest', op 'collectieve mentaliteiten' etc. Zulke theorieën moeten met de nodige scepsis worden bezien. 


\section{Opvattingen over kennis en de groei van kennis}

Wetenschappelijke kennis groeit. In het inleidende hoofdstuk zeiden we dat dit een van de karakteristieken is waarmee wetenschappelijke kennis zich van andere soorten kennis onderscheidt. Het gebeurt wel eens dat iemand afwezigheid van groei signaleert op een onderzoeksgebied. Schoenmakers (1990b: 185) meent dat er op zijn vakgebied, de theaterwetenschap, tussen het begin van de eeuw en 1967, toen een speciaal nummer van het tijdschrift Forum der Letteren aan de theaterwetenschap werd gewijd, van geen theoretische ontwikkeling gesproken kan worden. Dat is voor de wetenschappen uitzonderlijk. De wetenschap bouwt voort op het werk van voorgangers. Maar het gevoel schatplichtig te zijn aan de voorgangers heeft ook iets dubbelhartigs. Er moet ook ruimte zijn voor kritiek: het werk van de voorgangers is ook steeds onvoldoende, incompleet of verbeterbaar. Het is een centrale opgave van de wetenschapsfilosofie duidelijk te maken waar de vooruitgang in het wetenschappelijk onderzoek eigenlijk uit bestaat, en hoe 'verbeterbare' kennis er uit ziet. Om op het werk van voorgangers te kunnen voortbouwen moet dat werk op een bepaalde manier zijn ingericht. Als wetenschap een rationele onderneming is, moeten er criteria zijn waarmee bepaald kan worden wanneer wetenschappelijk onderzoek succesrijk is.

eerste kennismaking met het probleem van de groei van kennis

kwantitatieve evidentie voor de groei van kennis...
Op het eerste gezicht lijkt de vraag of de wetenschappelijke kennis zich uitbreidt, onnozel. Het is toch aan alles duidelijk dat de wetenschap zich uitbreidt. Kijk maar naar wetenschappelijke bibliotheken. Die worden steeds groter; dus, zo zou je kunnen zeggen, neemt de wetenschappelijke kennis ook toe. De Arts\&Humanities citation index $x^{*}$ vermeldt - afgezien van de boekbesprekingen - ongeveer 30.000 wetenschappelijke artikelen op het gebied van de geesteswetenschappen per jaar. Naast de tijdschriftartikelen zijn er natuurlijk boeken. Hoeveel wetenschappelijke boeken er jaarlijks verschijnen is onbekend, maar het aandeel van de humaniora er in is groot. 'Van de ca. $42 \mathrm{mln}$. boeken en

* Hier en in het vervolg wordt gebruik gemaakt van cijfers ontleend aan deze index. De A\&HCI geeft een kwantitatief overzicht van het gebruik dat alfa-onderzoekers maken van elkaars werk. De A\&HCI geldt als niet zeer betrouwbaar, maar is voor de humaniora de enige in zijn soort. De cijfers moeten met voorzichtigheid worden gehanteerd. 
... maar kennis veroudert ook

verouderingscurves van verschillende vakgebieden vergeleken tijdschriftafleveringen in de wetenschappelijke bibliotheken in Nederland $[\ldots]$ heeft naar schatting ruim $1 / 3$ betrekking op geesteswetenschappelijke vakgebieden.' (RAWB 1990: 8)

Maar er is niet alleen sprake van kwantitatieve aanwas van kennis, kennis veroudert ook. Publicaties zijn blootgesteld aan een proces van vergetelheid. De kennis die in tijdschriftjaargangen of in boeken is gebundeld, speelt een steeds geringere rol naarmate de publicaties ouder worden. De argumentatie voor die opvatting steunt op het citeergedrag van onderzoekers. Dit wordt door 'bibliometristen' onderzocht. Bibliometrisch onderzoek levert gegevens omtrent de vraag welke wetenschappelijke literatuur op welk moment door welke auteur wordt geciteerd.

In figuur 4 worden de verouderingscurves gepresenteerd voor vier vakgebieden. Ze laten zien hoe oud de literatuur was, waarnaar door onderzoekers in hun publicaties wordt verwezen. De curves van natuurwetenschappen en sociale wetenschappen zijn beide gebaseerd op grote hoeveelheden verwijzingen. Uit die van de natuurwetenschappen, gebaseerd op 9.000.00o verwijzingen van het jaar 1984 kan men globaal aflezen dat er in 1984 ongeveer 900.000 keer naar werk uit 1982 werd verwezen, en 'slechts' ongeveer 18.000 keer naar werk uit 1950. De curves voor de taalkunde en de (literair-)historische geschiedenis op aanmerkelijk kleinere aantallen: ongeveer 5000 citaties elk. Ze zijn ontleend aan tijdschriften waarnaar in het algemeen het meest wordt verwezen. Bij het verzamelen van de historische data is van de verwijzingen naar de (vaak veel oudere) primaire bronnen afgezien.

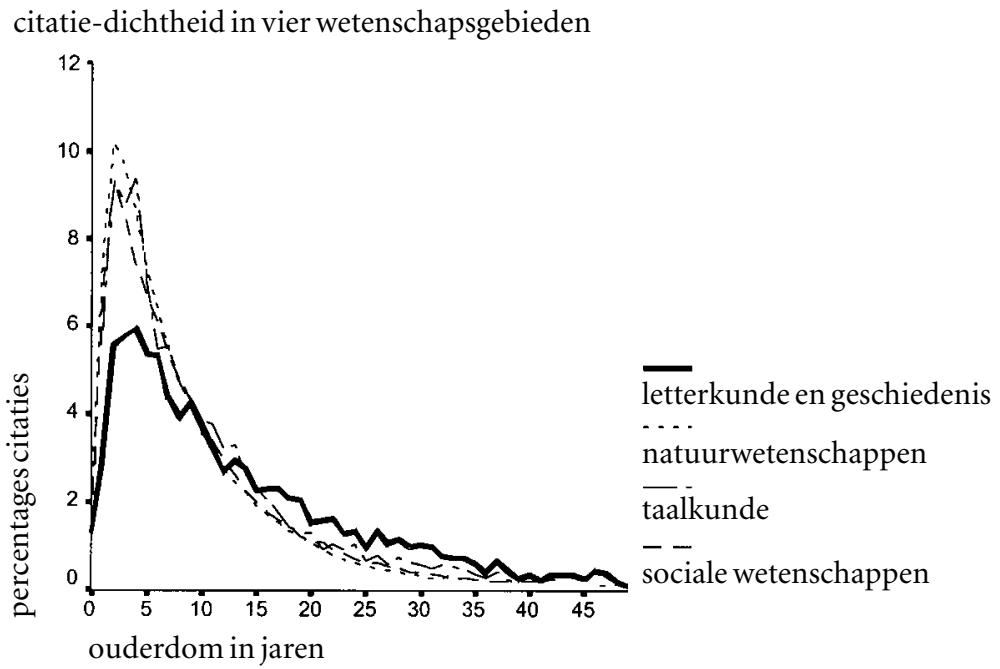

Figuur 4 Verouderingscitatiecurves van natuurwetenschappen, sociale wetenschappen, taalkunde en (literatuur-)geschiedenis 
het begrip groei van kennis in de wetenschapsfilosofie

vooruitblik

Het blijkt dat de curves voor alle vakgebieden ongeveer dezelfde vorm hebben. In alle vakgebieden treedt de veroudering van kennis op. Maar in de (literatuur-)historische vakken gaat het proces langzamer dan elders. Dat is in overeenstemming met de algemene indruk dat 'humanists cite much older material than scientists do', zoals een studie over het bibliotheekgebruik van geesteswetenschappers stelt (Couch en Allen 1993: xii). De meest waarschijnlijke verklaring is dat in de historische vakken slechts weinig mensen tegelijkertijd aan hetzelfde terrein van onderzoek werken. Daardoor zou het aantal relevante publicaties elkaar in een minder snel tempo opvolgen.

Hoe dit ook zij, de som van de aanwas en de veroudering van de literatuur kan maar gedeeltelijk het antwoord zijn op de vragen naar de groei van kennis. Per slot van rekening zou het ook zo kunnen zijn dat de nieuwe kennis die de onderzoekers produceren 'slechts' andere kennis is, geen betere; producten van een mode, geen stappen op weg naar waarheid.

De wetenschapsfilosofische vraag naar de groei van kennis is de vraag naar de vooruitgang van kennis. De vraag is niet of het aantal beschikbare publicaties over Shakespeare tegenwoordig omvangrijker is dan honderd jaar geleden, maar of het totaal van kennis over Shakespeare nu betrouwbaarder is dan toen.

We zullen in dit hoofdstuk eerst drie min of meer 'klassieke' opvattingen omtrent de aard van wetenschappelijke kennis en de vooruitgang van de wetenschappelijke kennis bespreken: die van Popper, die als eerste diepgaand over wetenschappelijke vooruitgang heeft geschreven, die van Kuhn die aantoonde dat Popper een onwerkelijke voorstelling van wetenschappelijke vooruitgang had gegeven, en die van Lakatos die de vondsten van Popper in een nieuw kader plaatst. Aan het einde van iedere paragraaf laten we zien hoe de inzichten van deze auteurs in de letterenvakken functioneren. In een vierde paragraaf staan we stil bij de opvattingen van Susan Haack, die recent een theorie over kennis ontwikkelde waarin recht gedaan wordt aan het idee dat theorieën gedeeltelijk een rechtvaardiging ontlenen aan coherentie. In een slotparagraaf proberen we samen te vatten wat groei van geesteswetenschappelijke kennis zou kunnen inhouden.

\section{Karl Popper}

tegenstander van dogmatische wetenPopper geldt als een van de belangrijkste filosofen van deze eeuw. In al zijn werk toont hij zich een tegenstander van een dogmatische attitude bij de wetenschapper. Die houding vindt hij belichaamd in Freud en Marx.

Einstein 'verbetert'

Daar stelt hij de houding van Einstein tegenover, de natuurkundige Newton 
fallibilisme

we leren van onze vergissingen

theorieën moeten kwetsbaar geformuleerd worden

ook waarnemingen zijn niet onbetwijfelbaar

kritisch rationalisme die aan het begin van de eeuw liet zien dat de zo onaantastbare wetten van Newton niet een universele geldigheid hebben. Einsteins houding is kritisch, zowel tegenover de gevestigde reputatie als tegenover zijn eigen werk.

Het is duidelijk dat Popper meent dat een wetenschapper steeds feilbaar is. Popper is een fallibilist. Hij vindt dat daarom van wetenschappelijk werk geëist moet worden dat het open is voor kritiek. De beste garantie vormt de houding van de onderzoeker: die moet altijd naar de weerlegging van zijn theorie zoeken, en niet naar de bevestiging. Steeds maar nieuwe bevestigingen leveren niet steeds maar nieuwe kennis op. De lezer herinnert zich de Hoogduitse klankverschuiving, die in hoofdstuk 4 aan de orde was. De paar voorbeelden die de klankwet illustreerden, waren voldoende om een idee te geven van de verschijnselen en ook voldoende om te overtuigen dat zulke regelmatigheden bestaan. Maar het zou niet verbazen als de lezer instinctief al snel ook de neiging zou voelen om te zoeken naar de tegenvoorbeelden, naar voorbeelden die afbreuk doen aan de algemeenheid van de wet. Dat is geheel in Poppers lijn. Nog meer voorbeelden kunnen de klankwet wel (her-)bevestigen, 'harder' maken, maar niet interessanter.

Vooruitgang kan alleen maar voortkomen uit het min of meer systematisch zoeken naar de tegenwerping tegen een veronderstelde regelmaat, niet van een nieuwe bevestiging ervan. Verwerping van een theorie zal de onderzoeker dwingen om niet alleen een andere theorie te vinden die de regelmaat verklaart, maar ook de grenzen aan de regelmaat die in de weerlegging zichtbaar is geworden.

Zoeken naar de zwakke plekken garandeert de vooruitgang van de wetenschap. Kennis moet kwetsbaar zijn. Daarvoor moet kennis open zijn. Theorieën moeten zo zijn geformuleerd dat ze toetsbaar, en dus in principe weerlegbaar zijn. Dogmatisch geformuleerde kennis is kennis die geen weerlegging toelaat, niet omdat dogmatische kennis waar zou zijn, maar omdat de kennis niet toetsbaar is.

Ook aan waarnemingsuitspraken, die een intersubjectieve zekerheid bieden, kan geen ontwijfelbare, 'objectieve' zekerheid worden ontleend. Ook waarnemingen zijn 'verbeterbaar', bijvoorbeeld door het gebruik van nieuwe 'waarnemingstechnieken'. Omdat de ontwikkeling van nieuwe waarnemingstechnieken niet ten einde is, moeten we ook ten aanzien van de zekerheid van waarnemingen een slag om de arm houden: ze zouden in de toekomst onjuist kunnen blijken. Dit alles moet de onderzoeker tot een houding van bescheidenheid brengen. Popper brengt dit in het adagium van Socrates tot uitdrukking: 'Ik weet zeker dat ik niets zeker weet.'

Popper heeft in zijn publicaties aanzienlijk bijgedragen aan het inzicht in de werkwijze van wetenschappers, die erkennen dat hun werk 


\section{Karl Popper, Wenen 1902 - Londen 1994}

Wenen was in het begin van de twintigste eeuw een politieke, culturele en intellectuele smeltkroes. Daar groeit Popper op. Als jongen is hij politiek actief in de communistische partij, maar hij raakt snel gedesillusioneerd. Kort voor zijn zeventiende verjaardag is hij getuige van een schietpartij tijdens een politieke demonstratie. Popper acht zichzelf als marxist medeverantwoordelijk.

Marxist theory demands that the class struggle be intensified, in order to speed up the coming of socialism. Its thesis is that although the revolution may claim some victims, capitalism is claiming more victims than the whole socialist revolution. [...] Communism claims to be based on knowledge: knowledge of the laws of historical development. I questioned whether I really knew - whether what I thought was knowledge was not perhaps mere pretence.

Aan zijn korte flirt met het marxisme hield Popper een reeks wijze lessen over.

It taught me the wisdom of the Socratic saying, 'I know that I do not know'. It made me a fallibilist, and impressed on me the value of intellectual modesty. And it made me most conscious of the differences between dogmatic and critical thinking.

In hetzelfde jaar 1919 maakte Popper ook nog kennis met twee psychologische stromingen, die van Adler en Freuds psychoanalyse, die hij later evenzeer als het Marxisme als dogmatische pseudo-wetenschap zou afwijzen.

In mei van dat jaar werd door twee Britse expedities een meting aan de baan van licht gedaan, die alleen bij een eclips kon plaatsvinden. De meting bevestigde een voorspelling van Einstein. Door die uitgekomen voorspelling bleek Einsteins theorie van de zwaartekracht beter dan die van Newton. Popper - opgegroeid met het idee dat Newtons theorie een onwankelbaar (en universeel, d.w.z. overal geldig) fundament van de natuurwetenschap was, - was diep geschokt.

[...] what impressed me most was Einstein's own clear statement that he would regard his theory as untenable if it should fail in certain tests. [...] This, I felt, was the true scientific attitude. It was utterly different from the dogmatic attitude [of Marx, Freud, Adler, and even more so that of their followers] which constantly claimed to find 'verification' for its favourite theories.

Bron: K. Popper, Unended quest. An intellectual autobiography 
rationeel is zonder te kunnen bewijzen dat het resultaat van hun onderzoek de 'waarheid' is. Dit gedachtecomplex staat bekend onder de naam kritisch rationalisme. David Miller, de auteur van een inleiding op een bloemlezing uit het werk van Popper, legt dit begrip als volgt uit:

Its emphasis, unlike that of previous philosophies, is on guesswork as the way it grows, and on criticism as the way it is controlled. Popper himself describes it by saying that knowledge evolves through a sequence of conjectures and refutations, of tentative solutions to problems, checked by searching and uncompromising tests. There is little place in critical rationalism for the preoccupying worries of traditional philosophy: whether our knowledge is securely founded, and if it is, how it is. [...] Arguments, according to critical rationalism, are always negative; they are always critical arguments, used only and needed only to unseat conjectures that have been earlier surmised. (Miller 1985: 10-11)

methodologisch falsi- $\quad$ Poppers opvattingen over de manier waarop die kritische instelling van ficationisme

falsificationisme tegenover verificationisme

dogmatisch falsificationisme de wetenschapper geacht wordt te werken, staan bekend onder de naam methodologisch falsificationisme. Wat is daarmee bedoeld?

Een oud idee over wetenschappelijk onderzoek zegt dat het doel van wetenschap is het doen van beweringen, die bewezen kunnen worden. Alleen die kennis zal worden geaccepteerd die bewezen is. Deze opvatting heet verificationisme. In Poppers voetspoor hebben we eerder al betoogd dat alle theorieën zonder uitzondering onbewijsbaar zijn. De beperkingen van de inductie, het zgn. inductieprobleem, zitten de wetenschappers hier dwars. Dat de wetenschap alleen die beweringen wetenschappelijke kennis zou mogen noemen, die bewezen zijn, is daarom ook een te strenge eis. Anders gezegd, verificatie is als demarcatiecriterium niet geschikt. Het verificationisme is voor de wetenschap een dwaalweg.

Het falsificationisme komt voort uit de erkenning dat de wetenschap met minder genoegen moet nemen; en dus ook minder aanspraken op waarheid kan doen gelden dan altijd werd gedacht. Lakatos, overigens zelf een falsificationist, noemt het falsificationisme een aanzienlijke concessie van het rationele denken. Het geeft toe dat onze rationaliteit beperkt is.

Het falsificationisme is de naam voor de opvatting dat die theorieën als wetenschappelijk kunnen gelden die zo zijn geformuleerd dat ze weerlegbaar zijn. Het falsificatiecriterium is als criterium om wetenschappelijke van niet-wetenschappelijke kennis te onderscheiden geschikter dan het verificatiecriterium.

De dogmatische variant van het falsificationisme stelt dat zoiets kan; dat het inderdaad aan mensen gegeven is om een theorie zo te formuleren 
Popper is methodologisch falsificationist

de natuurlijkheid van de empiricistische standpunten

Popper over de onzekerheid van feiten dat het mogelijk is een volstrekt zekere toets te bedenken die de theorie met volstrekte zekerheid weerlegt. Dit dogmatisch falsificationisme houdt vast aan het idee dat er een volstrekte zekerheid kan bestaan omtrent iets dat in de werkelijkheid wordt waargenomen. Dat wil zeggen: het dogmatisch falsificationisme erkent de feilbaarheid van theorieën, maar niet die van het waarnemingsvermogen. Feiten zijn hard, menen zij; feiten zijn de werkelijkheid zelf en de werkelijkheid liegt niet. Dogmatisch falsificationisten zijn 'foundationalists', wetenschappelijke fundamentalisten: ze delen de mening dat wetenschap met volstrekte objectieve zekerheid in de feiten kan worden gefundeerd. Men herinnere zich de pogingen van Mach, Russell, Wittgenstein en Carnap (vgl. paragraaf 3.2.2) om aan te geven hoe de beweringen er uit moesten zien waaraan deze volstrekte zekerheid kon worden toegeschreven. Volgens foundationalisten is er een rockbottom of knowledge.

Popper nu is geen dogmatisch, maar een methodologisch falsificationist. Popper huldigt de opvatting dat we niet alleen over de theorieën niet absoluut zeker kunnen zijn, maar evenmin over de feiten. Feiten zijn én door het standpunt van de waarnemer én door de gebruikte waarnemingsinstrumenten én door de gekozen woorden om de waarnemingen te verwoorden theoriegeladen. Dit kwam al eerder aan de orde. Over feiten hebben we zekerheid omdat we daarover beslissingen nemen, afspraken maken, maar niet omdat we de observaties waarop ze berusten, nader kunnen rechtvaardigen. Met theorieën kunnen we feiten niet rechtvaardigen omdat theorieën - in de visie van de falsificationisten altijd een onzeker element hebben. Hoe zouden we ze dan wel kunnen 'bewijzen'? In Poppers visie bestaat er geen rockbottom of knowledge.

Veel mensen vinden dit maar moeilijk gedoe, filosofische spijkers op laag water. Men kan zijn eigen ogen en oren toch wel vertrouwen? Als ik zeg: 'Daar staat een glas water op tafel', dan hoeft daar toch niet aan getwijfeld te worden? En als ik in de krant heb gelezen dat er een aardbeving geweest is in Griekenland, dan hoef ik daar toch niet aan te twijfelen?

Deze overwegingen lijken spijkerhard, en lange tijd klampten ook heel streng over 'waarheid' en 'kennis' sprekende filosofen zich aan deze zekerheden vast. We zagen echter in het voorgaande al dat psychologisch onderzoek naar het waarnemingsproces steun biedt voor het idee dat waarneming theoriegeladen is. Hier volgen een paar citaten uit het werk van Popper die duidelijk pogen te maken hoe hij de 'empiricistische' zekerheden ondergraaft, de zekerheden van hen die zeggen: je kunt toch je zintuigen wel vertrouwen; zintuiglijke gewaarwordingen zijn toch 'hard'?

Popper constateert dat de vraag naar de grondslag van onze kennis, naar de rockbottom of knowledge, een eindeloze ketting van vragen tot gevolg heeft. Hij voert een lezer L. van The Times ten tonele die in zijn krant 
heeft gelezen dat de Prime Minister besloten heeft een paar dagen eerder dan aanvankelijk het plan was, terug te keren naar Downing Street 10. De lezer wil weten hoe ze dat zo zeker weten. L. belt The Times en vraagt hoe zij dat weten van de Prime Minister. De redacteur van The Times antwoordt dat ze een telefoontje hebben gehad van het kantoor van de Prime Minister, om dit mee te delen. L. kan vervolgens vragen wie de ambtenaar was die het bericht doorgaf, maar om zeker te zijn moet hij ook aan de redacteur van The Times vragen: 'What is the source of your knowledge that the voice you heard came from an official in the Prime Minister's office?' en zo voort en zo verder.

There is a simple reason why this tedious sequence of questions never comes to a satisfactory conclusion. It is this. Every witness must always make ample use, in his report, of his knowledge of persons, places, things, linguistic usages, social conventions, and so on. He cannot rely merely upon his eyes or ears, especially if his report is to be of use in justifying any assertion worth justifying. But this fact must of course always raise new questions as to the sources of those elements of his knowledge which are not immediately observational.

This is why the programme of tracing back all knowledge to its ultimate source in observation is logically impossible to carry through: it leads to an infinite regress. (Popper 1985: 46-49)

Terugwerken naar de bron van je informatie confronteert je dus met de vraag naar de geloofwaardigheid van de bron, of, als je zelf je eigen 'informant' bent, met de omstandigheid dat je eigen observatie wel voor jezelf maar niet voor een ander een eigen observatie is. Het citaat is evenwel geen antwoord op de vraag waarom we in het dagelijks leven zo succesvol een beroep doen op onze zintuigen, en waarom dit ervaringsgegeven desondanks geen harde, onbetwijfelbare grondslag kan zijn van 'wetenschappelijke kennis'.

de principiële onmogelijkheid te laten zien dat de werkelijkheid niet eenduidig is

Voor een antwoord op deze vraag keren we nog eens terug naar de functie van coherentie als kentheoretische notie, zoals we die in hoofdstuk 6 hebben beschreven. We zagen daar dat we met succes een beroep op coherentie kunnen doen als verschijnselen in de werkelijkheid los van de context dubbelzinnig zijn. Veel verschijnselen manifesteren zich evenwel eenduidig. Dat is de reden dat we blindelings op ons waarnemingsvermogen vertrouwen. Dat is ook de reden waarom we zoveel dingen voor feitelijk waar houden. 'Feiten' - zo zeiden we in 4.1.2 -, 'feiten zijn verschijnselen die niet voor tweeërlei uitleg vatbaar zijn.' Maar of een verschijnsel echt eenduidig is en geen andere interpretaties toelaat, weten we niet zeker. Merk op dat dit afhankelijk is van ons (on-)vermogen contexten te verzinnen waarin het verschijnsel meer dan een interpretatie 
Popper en de groei van kennis heeft. We hebben over de eenduidigheid van het verschijnsel geen zekerheid. We hebben geen middel om deze onzekerheid op te heffen. Het ontbreken van een rockbottom of knowledge is hiervan een consequentie. Belangrijk is echter dat we meestal ook geen reden hebben om er naar te zoeken. Een rockbottom of knowledge zullen we slechst zelden missen.

We verwijzen nog eens naar het geval van de damessandaal, aan de orde gesteld in hoofdstuk 4. De verschillende benadering van de feiten door het lid van de Tweede Kamer enerzijds en de foneticus anderzijds met betrekking tot het aantal [s]-klanken in het woord damessandaal berusten op beslissingen, conventies, afspraken, niet op een objectief fundament. We kunnen dit nu als volgt herinterpreteren. De waarneembare werkelijkheid is dubbelzinnig: men hoort één of twee s-en. Het TweedeKamerlid hoort er twee, en kan zich niet voorstellen dat de werkelijkheid dubbelzinnig zou zijn. Met zijn waarneming is voor hem de kous af. Hij zou echter desgevraagd niet aannemelijk kunnen maken dat zijn waarneming eenduidig is, en hij zal er ook geen behoefte aan hebben dat aannemelijk te maken. Men kan daarom niet zeggen dat er voor hem een rockbottom of knowledge is, en evenmin dat hij die mist. De fonetici nemen een verschijnsel waar waarvan zij de interpretatie 'er is één s' kunnen inpassen in hun theorieën en waarnemingstechnieken. De interpretatie 'er zijn twee s-en' is niet inpasbaar. Ook zij houden de observatie 'er is één $s$ ' ingebed in het kader van hun theorieën en waarnemingstechnieken slechts voor één duiding vatbaar. Dit laatste zullen zij evenwel niet kunnen bewijzen, en daarom kan men ook van hun kennis niet zeggen dat die op een rockbottom is gebouwd.

Hoe dit verder ook zij, ook zonder rockbottom of knowledge kan worden betoogd dat de kennis groeit. Kennis groeit, zegt Popper, wanneer een door de feiten verslagen theorie wordt opgevolgd door een andere theorie die én de oude feiten verklaart, én de feiten die voor de oude theorie te weerbarstig waren. Uit de nieuwe theorie moeten ook nieuwe toetsbare beweringen kunnen worden afgeleid. De status van die nieuwe theorie is een tijdlang onzeker, maar als hij toetsen doorstaat, zal het vertrouwen in de nieuwe theorie groeien, ook al wordt de zekerheid niet $100 \%$. Als de feiten ook die nieuwe theorie om zeep helpen, wordt ook de nieuwe theorie verworpen, en na verloop van tijd opgevolgd door weer een nieuwe. Omdat iedere nieuwe theorie in deze reeks steeds meer feiten verklaart, kan worden gezegd dat onze kennis toeneemt. (Popper 1992: 39) In termen van de boom van deducties: als $\mathrm{P}_{2}$ onwaar is en de empirische inhoud van bewering $\mathrm{P}$ dus gedeeltelijk niet in overeenstemming met de werkelijkheid, dan is P zelf onwaar. Het onderzoek naar de aard van de gevonden strijdigheid leidt tot het opstellen van een nieuwe theorie. Die nieuwe theorie heeft dan overtuigingskracht als die alle feiten verklaart die de oude theorie verklaarde, en zo mogelijk meer, maar 
Popper en de geesteswetenschappen een empirische inhoud heeft waarvan $\mathrm{P}_{2}$ geen deel uitmaakt. Zolang $\mathrm{P}$ standhoudt, is het een natuurlijk streven van onderzoekers om het bereik van $P$ te vergroten, dat wil zeggen een theorie op te stellen waar P zelf uit kan worden afgeleid. Van zo'n theorie is de empirische inhoud groter, en dus ook het aantal toetsingsmogelijkheden. Beide ontwikkelingen gelden als vooruitgang, en als een toenadering tot de 'waarheid'. Omdat we de empirische inhoud van een theorie evenwel nooit compleet kunnen kennen, de theorie dus ook nooit compleet kunnen testen, kunnen we niet zeggen dat we de waarheid ooit zullen bereiken.

Popper is onder geesteswetenschappers een favoriete auteur. Er kan geen historicus afstuderen zonder degelijk met de begrippen 'falsificatie', 'empirische inhoud' en het 'fallibilisme' geconfronteerd te zijn, zoals de historicus Koch in een herdenkingsartikel over Popper schreef. Wetenschapstheoretische uiteenzettingen op het gebied van de taalkunde (Kerstens en Sturm 1989) en van de literatuurwetenschap (bijvoorbeeld Fokkema 1990) zijn ook vaak in hoge mate op die ideeën gestoeld. Daarbij is soms de bewondering groter voor de wetenschappelijke attitude die Popper voorstond: 'openheid-voor-kritiek', 'bescheidenheid', 'anti-dogmatisch karakter', dan voor de verheldering van het eigen wetenschappelijk bedrijf.

Onder historici is het bijvoorbeeld niet ongewoon dat verschillende en niet zelden tegenstrijdige theorieën, visies en uitspraken gezellig jarenlang naast elkaar voortbestaan, zonder dat er ogenschijnlijk sprake is van welke krachtmeting [van theorieën] dan ook - laat staan eliminatie. Afgezien van Poppers tamelijk slappe uitvlucht dat historici geen theorieën hebben maar alleen 'gezichtspunten', blijkt hieruit toch al dat Poppers falsificatie-principe niet zo eenvoudig en rigoureus werkte als hij hoopte. Anderzijds is het zo dat vele geschiedkundige conclusies die een halve eeuw geleden als 'waar' golden, thans door niemand in de historische wereld meer worden geaccepteerd. Er is dus wel degelijk zoiets als een eliminatie-proces gaande. Wetenschap in de praktijk - en zeker geschiedwetenschap [...] gaat veel langzamer en onvoorspelbaarder dan Popper voor mogelijk hield. (Bommeljé 1995: 7-8)

Soms (of vaak) wordt dus een bestaande theorie niet expliciet weerlegd om vervolgens door een andere te worden vervangen, maar verschijnt er naast een bestaande theorie een nieuwe die na verloop van tijd de vorige blijkt te hebben verdrongen, zonder dat precies duidelijk is geworden waarom. Dit hangt ongetwijfeld hiermee samen dat historische theorieën niet gemakkelijk een vorm gegeven kan worden die ze geschikt maakt voor een heldere toetsing. 
inleiding

Kuhns sociologische benadering van de wetenschappen
Thomas Kuhn is een natuurkundige die zich vooral heeft bezig gehouden met de geschiedenis van de wetenschappen, speciaal met de geschiedenis van de natuurwetenschappen. Zijn bekendste publicatie is The structure of scientific revolutions uit 1962. In 1958 werd hij uitgenodigd een tijd te studeren aan een onderzoeksinstituut voor de sociale wetenschappen. Daarover schrijft hij het volgende.

Belangrijker nog was dat een jaar in een gemeenschap, die voornamelijk bestond uit beoefenaren van de sociale wetenschap, mij confronteerde met onvermoede problemen aangaande de verschillen tussen zulke gemeenschappen en die van de beoefenaren van de natuurwetenschap te midden van wie ik was opgevoed. Ik werd in het bijzonder getroffen door het aantal en de omvang van de openlijke meningsverschillen tussen sociale wetenschappers over de aard van echte wetenschappelijke problemen en methoden. Zowel de geschiedenis als de directe ervaring deden me eraan twijfelen dat de beoefenaren van de natuurwetenschappen betrouwbaarder of duurzamer antwoorden bezaten op zulke vragen dan hun collega's van de sociale wetenschap. Toch veroorzaakt de praktijk van de astronomie, de natuurkunde, de scheikunde of de biologie op de een of andere manier geen meningsverschillen over fundamentele zaken die vandaag de dag bijvoorbeeld bij psychologen of sociologen lijken te horen. Een poging om de oorzaak van dat verschil te ontdekken verschafte me inzicht in de belangrijke rol die bij het wetenschappelijk onderzoek wordt gespeeld door wat ik sindsdien 'paradigma's' heb genoemd. Dit zijn algemeen aanvaarde wetenschappelijke prestaties die een tijd lang modelproblemen en modeloplossingen verschaffen aan een gemeenschap van onderzoekers.

Kuhn kijkt naar de ontwikkeling van de wetenschappen met een sociologische, of historische blik. Zijn uitgangspunt is dat er in de wetenschap groepen onderzoekers zijn te onderscheiden die hetzelfde specialisme beoefenen. De onderzoekers van zo'n groep zijn op dezelfde manier opgeleid, kennen dezelfde standaardliteratuur, spreken dezelfde 'taal', hebben officiële en niet-officiële communicatiekanalen. Als je dit soort criteria hanteert, zegt Kuhn, dan levert dat in het algemeen groepen wetenschappers op van misschien honderd leden, misschien minder. 'Gewoonlijk behoren individuele wetenschappers, in het bijzonder de meest competente, tot verscheidene van deze groepen tegelijk of veranderen ze meermalen van groep.' (Kuhn 1979: 230) 
het begrip 'paradigma'

Kuhn en de vooruitgang van de wetenschap

kritiek op Kuhn
Ook de gemeenschappelijke ideeën van zo'n groep, vangt Kuhn onder de term 'paradigma'. Hij bedoelt ermee de overtuigingen en waarden, die de groep gemeenschappelijk heeft; dus ook de theorieën waarover 'zekerheid' bestaat, en dat wat men eventueel bereid is als een oplossing van een zeker probleem te aanvaarden. Ook is er duidelijkheid over de maatgevende voorbeelden van wetenschapsbeoefening die navolging verdienen. In een groep waarin er een paradigma bestaat, houdt men zich bezig met het oplossen van puzzels, niet systematisch met het verleggen van grenzen. De belangrijkste basistheorieën zijn onaantastbaar. En tegenvoorbeelden worden niet zomaar als een weerlegging van een succesrijke theorie beschouwd. Een theorie vertoont een zekere taaiheid tegenover een negatief resultaat van een toetsing. De groep evalueert zelf de eigen prestaties.

Af en toe raakt zo'n groep in een 'crisis'. Door een of ander opduikend theoretisch inzicht wordt er geraakt aan basisveronderstellingen van de groep. Dan kunnen tegenvoorbeelden ineens wel gaan tellen. Als dit inzicht sterk genoeg is, en voldoende belovend, ontstaat er een 'revolutie'. De oude zekerheden worden overboord gezet en door nieuwe vervangen. Er vestigt zich een nieuw paradigma. Een wetenschapsgebied ontwikkelt zich dus doordat paradigma's elkaar afwisselen.

Is het proces waarin periodes van 'normale wetenschap' en 'wetenschappelijke revoluties' elkaar afwisselen, nu ook als vooruitgang te karakteriseren? Kuhn spreekt bij voorkeur van een evolutieproces van de wetenschappen dat vergelijkbaar zou zijn met de evolutie van de cultuur. Net zoals er in de cultuur wel verandering maar geen vooruitgang kan worden geconstateerd, is dat ook bij de wetenschappen zo. Kuhns stelling is dat er tussen leden van twee verschillende paradigma's principieel geen zekerheid bestaat dat zij dezelfde 'taal' spreken. In hoofdstuk 2.1 hebben we daar al over gesproken. En om die reden zou ook niet vaststelbaar zijn dat de wetenschappen als geheel de waarheid steeds dichter benaderen. Paradigma's zijn incommensurabel. Er is niet een hogere 'objectievere' maatstaf voor het meten van de prestaties die onder verschillende paradigmata zijn geleverd, tenminste niet een maatstaf die als zodanig door de leden van beide paradigma's wordt erkend. De 'incommensurabiliteit', de 'onvergelijkbaarheid' van paradigma's verhindert dat kan worden vastgesteld dat het jongste paradigma een vooruitgang is ten opzichte van het oudere.

Kuhn is op grond van deze opinie verweten een relativist te zijn, iemand die ontkent dat er een rationele grondslag voor de keuze tussen theorieën zou kunnen worden gevonden; iemand die erkent dat een keuze voor een theorie een kwestie van een individuele voorkeur is; iemand die meent dat de waarheid relatief is. 
Kuhns succes

Kuhn en de geesteswetenschappen

paradigmata in de geschiedbeoefening?
Volgens Kuhn is wetenschappelijke verandering - de overgang van het ene 'paradigma' naar het andere - een mystieke bekering die niet wordt beheerst en ook niet kan worden beheerst door de regels van de rede en geheel valt binnen het onderzoeksterrein van de (sociale) onderzoekspsychologie. Wetenschappelijke verandering is een soort godsdienstige bekering. (Lakatos 1970: 2)

Het relativisme waartoe Kuhns incommensurabiliteitsbegrip leidt, is voor veel mensen een niet te verteren consequentie. Vandaar dat er gezocht is naar uitwegen om aan deze consequenties te ontkomen. Lakatos heeft daaraan een belangrijke bijdrage geleverd.

Kuhns boek is erg invloedrijk geweest. Men vindt het bovenaan in de lijst van de 50 meest geciteerde werken in de humaniora in de jaren zeventig. Ten eerste was de beschrijving van de groepen onderzoekers die een paradigma gemeenschappelijk hadden, zeer herkenbaar. Gefundeerd als het paradigmabegrip was in een degelijke kennis van de wetenschapsgeschiedenis, leek Kuhns visie meer rekening te houden met de praktijk van de onderzoekers, dan de normatieve standpunten van Popper. Bovendien verschafte Kuhn een soort legitimatie aan onderzoekers die zich in een eigen paradigma wilden verschansen. Immers, allerlei groepen die elkaar op grond van gemeenschappelijke uitgangspunten vonden, konden zich onttrekken aan rationele kritiek van anderen. Veel wetenschappers lijken ook helemaal niet de bedoeling te hebben de theorieën waarop ze zich baseren, steeds ter discussie te stellen, zoals Popper veronderstelt, maar beperken het eigenlijke werk tot het oplossen van puzzels.

Het werk van Kuhn is bij de geesteswetenschappers controversieel. Velen hebben zich op zijn werk beroepen. Maar dezelfde bezwaren als in het bovenstaande al ter sprake kwamen, zijn ook hier te horen. De begrippen 'paradigma' en 'groep' zijn niet glashelder, en 'relativisme' is een onaantrekkelijke consequentie, zoals we in hoofdstuk 2 al lieten zien. Kuhns theorieën zijn overigens voor de geesteswetenschappen niet grondig op hun houdbaarheid onderzocht. In het algemeen moet men zeggen dat de sociologie van de geesteswetenschappen (niet alleen in Nederland, maar ook die in andere landen) een onderontwikkeld terrein is, en daarvan zou men het bij een toetsing van Kuhns ideeën toch moeten hebben. Proberen we daarom enkele indrukken onder woorden te brengen.

Waar zou eventueel van verschillende paradigmata kunnen worden gesproken? In een discussie met een andere historicus merkt Fogel op dat het verschil tussen een kwantitatieve, cliometrische benadering van de geschiedenis en een 'traditionele', niet-kwantitatieve kan wijzen op een paradigmaverschil. (Fogel en Elton 1983: 40) Er zijn andere data, andere vraagstellingen, andere manieren van bewijsvoering, andere samenwer- 
cliometrische benadering

beschrijft collectief gedrag; zich herhalende gebeurtenissen

gelijksoortige data

kwantitatieve bewijsvoering; sociaal-wetenschappelijk

onderzoek is vaker teamwork

men schrijft voor vakgenoten traditioneel-historische benadering

beschrijft gedrag van (bijzondere) individuen

unieke data

hermeneutische bewijsvoering; als in een rechtszaak

onderzoek is kleinschalig en individueel

men schrijft voor een algemeen publiek

Tabel 2 Aspecten van cliometrische en traditionele geschiedbeoefening in de visie van Fogel (naar Fogel en Elton 1983)

kingsverbanden tussen onderzoekers en er is een andere relatie met het niet-historisch publiek. De verschillen, zoals Fogel die ziet, zijn in tabel 2 schematisch weergegeven.

Hoewel Fogels discussiepartner Elton het niet steeds met de analyse van Fogel eens is, concluderen de beide discussianten toch dat de overeenkomsten groter zijn dan de verschillen. Ze zijn het erover eens dat ze geen verschillende kwaliteitsstandaarden van historisch werk hanteren. Beide benaderingswijzen zijn dus niet incommensurabel: de resultaten van het werk van de ene richting zijn bruikbaar in het werk van de andere. Ook is er nog geen sprake van dat het oudste 'paradigma', het traditionele, bezig is het veld te ruimen voor het jongste.

paradigmata in de literatuurwetenschap?
Tegenstellingen tussen groepen onderzoekers die kwantitatieve methoden gebruiken en groepen die een niet-kwantitatieve cultuurhistorische of hermeneutische benadering prefereren, bestaan ook elders in de geesteswetenschappen, met name bij de literatuurwetenschap. Wat de cliometrie is in de geschiedbeoefening, is de zgn. empirische literatuurwetenschap in de beoefening van de letterkunde. De empirische literatuurwetenschap onderzoekt met sociaal-wetenschappelijke methoden herhaalbare, dus kwantificeerbare aspecten van het literaire systeem: reacties van lezers bijvoorbeeld. Maar ook hier is de situatie niet helder in het Kuhnse kader onder te brengen. De literatuurwetenschap wordt door sommigen voor preparadigmatisch gehouden. Daarmee wordt tot uitdrukking gebracht dat er nog geen paradigma voor het vakgebied bestaat, en dat - in afwachting daarvan - iedere onderzoeker zijn eigen theoretisch kader ontwerpt. Anderen menen dat de situatie eerder te kenschetsen is als polyparadigmatisch: er bestaan verschillende paradigma's naast elkaar. (Cf. Van Buuren 1988) Er bestaat animositeit tussen de onderzoekers, maar geen incommensurabiliteit. Uit een interview met 
paradigmata in de taalkunde?

\section{$7 \cdot 3$}

het begrip 'onderzoeksprogramma'
Arie Gelderblom, een van de hoofdredacteuren van een nieuwe Nederlandse literatuurgeschiedenis, blijkt bijvoorbeeld dat men in dat boek de resultaten van de verschillende benaderingswijzen beoogt te integreren. (Cf. Harsema en Schröder 1998)

Ook in de taalkunde vindt men wel tegenstellingen tussen groepen onderzoekers die als paradigmatische verschillen kunnen worden gekarakteriseerd. Beoefenaren van de communicatiekunde, de fonetiek en de tekstlinguïstiek oriënteren zich op de sociale wetenschappen, terwijl de beoefenaren van de generatieve grammatica eigen onderzoeksmethoden bezigen. De laatsten moeten weinig hebben van experimenten of van gekwantificeerde grootheden, de eersten hebben problemen met het gebruik van intuities als data. De verschillende groepen onderzoekers hebben ook duidelijk eigen vraagstellingen, eigen verenigingen, congressen en tijdschriften. Ook hier is het echter de vraag of de resultaten van het onderzoek vanuit deze beide groepen incommensurabel zijn. Psycholinguïstische onderzoekers, doorgaans niet als taalkundige of foneticus opgeleid, maar als psycholoog, lijken op zijn tijd wel degelijk resultaten van het ene veld in het andere te integreren.

\section{Imre Lakatos}

De filosoof-logicus Imre Lakatos, van Hongaarse origine, maar tot zijn dood in 1974 werkzaam in Londen, liet het sociologische uitgangspunt van Kuhn los, maar handhaafde de collectivistische notie die daarin verpakt zit. In plaats van 'theorie' als eenheid van wetenschappelijk werk te nemen, zoals Popper doet, spreekt Lakatos over onderzoeksprogramma's. Wetenschappers werken (alleen of in een groep) aan een aantal verschillende theorieën tegelijk. Het zijn jongleurs die steeds een aantal theorieën tegelijkertijd in de lucht proberen te houden. Popper suggereert dat er in de loop van de tijd steeds één theorie is die de meest geavanceerde verklaring van het beschikbare empirische materiaal biedt. In feite echter is de situatie in een wetenschapsgebied altijd gecompliceerder.

- Ook zonder falsificatie van een eerste theorie $\mathrm{T}_{1}$ zijn er rivaliserende theorieën $\mathrm{T}_{2}, \mathrm{~T}_{3}$ etc. beschikbaar, waarvan het succes lange tijd onzeker is.

- Ook wordt een theorie niet zomaar meteen voor een weerbarstig tegenvoorbeeld opgegeven, al was het maar omdat het tegenvoorbeeld zelf ook 'theoriegeladen' is, zoals we hebben gezien.

- Ook de theorieën die in de waarneming verborgen zitten, zijn bronnen van onzekerheid. In de apparatuur waarmee de waarneming wordt verricht, in de veronderstellingen van de waarnemer of in de 
progressieve en degenererende onderzoeksprogramma's

Lakatos en de geesteswetenschappen

voorbeelden van onderzoeksprogramma's in de letteren woorden die gekozen zijn om de waarneming onder woorden te brengen, kunnen verborgen veronderstellingen zitten die niet noodzakelijk juist zijn.

- Bovendien kunnen er soms hulphypotheses worden geformuleerd met een eigen verklarende kracht - die alsnog de theorie redden, omdat ze het bestaan van de tegenvoorbeelden als het ware verklaren.

Dit betekent dat in de praktijk van het onderzoek een wetenschapper altijd met een hele reeks theorieën tegelijkertijd te maken heeft. Dit conglomeraat noemt hij een onderzoeksprogramma. Daarbij hoeft niet in de eerste plaats aan een expliciet geformuleerd programma gedacht te worden; een onderzoeksprogramma in de bedoelde zin kan ook zoiets zijn als een stroming, een traditie: een stilzwijgende overeenstemming tussen onderzoekers die met dezelfde methodes in dezelfde richting werken.

In een onderzoeksprogramma zal tegelijkertijd naar bevestiging en weerlegging van vermoedens worden gezocht. Maar niet van alle theorieën tegelijkertijd. Het is weer een kwestie van afspraken welke theorieën (een tijdlang) als onaantastbaar gelden. Hier vertoont het begrip onderzoeksprogramma een grote overeenkomst met de notie paradigma, zoals die door Kuhn wordt gehanteerd. Lakatos spreekt van een harde kern van theorieën die een onderzoeker zolang mogelijk buiten schot zal willen houden, om daardoor des te meer inzicht te krijgen in de hardheid van de theorieën die wel aan toetsingen onderworpen worden.

Onderzoeksprogramma's hebben een tijdlang een progressieve werking. Onderzoekers hebben het idee dat ze door de keuzes voor de harde schil en de onderzoeksmethodes veel nieuwe inzichten verwerven. Op een gegeven moment echter raakt het programma uitgeput; het levert weinig nieuwe inzichten meer op; de vondsten zijn niet meer spannend. Het programma degenereert. Het wordt tijd om te zien of er niet een nieuw programma kan worden gestart. Bij de formatie van nieuwe onderzoeksprogramma's wordt kennis benut die men in voorlopige vorm in andere onderzoeksprogramma's heeft gevonden.

De indruk bestaat dat aan het werk van Lakatos bij de verschillende geesteswetenschappen weinig aandacht is geschonken. Het zou kunnen zijn dat dit komt door het karakter van het onderzoek in de geesteswetenschappen, dat wijd en zijd als 'kleinschalig' wordt gekenschetst. Veel onderzoek is een eenmans- of eenvrouwsproject. Zeker voor vakken in een preparadigmatische situatie hoeft dat ook niet te verwonderen.

Onderzoeksprogramma's zijn in de geschiedenis van de geesteswetenschappen van betrekkelijk recente datum. Het enige vroeg-negentiendeeeuwse voorbeeld dat in de buurt lijkt te komen, is dat van de vergelijkende Indo-europese taalwetenschap dat gericht was op het vaststellen van de aard van de verwantschap tussen de talen in het Indo-europese taalge- 
bied. We hebben al opgemerkt dat het een zeer succesrijk programma is geweest, dat als vorm van wetenschap een zeer groot aanzien heeft gehad. Het is in het eerste kwart van deze eeuw 'gedegenereerd' geraakt en onder andere opgevolgd door de dialectologie. De dialectologie leidde zelf in heel Europa en daarbuiten tot nieuwe, regionaal gespreide onderzoeksprogramma's; vooral gericht op de vervaardiging van kaarten van dialectverschijnselen. Ook de dialectologie is gedegenereerd geraakt. De sociolingü̈stiek is te zien als de opvolger ervan. Het is een vakgebied dat niet in regionale maar in sociaal bepaalde taalvariatie geïnteresseerd is, een programma dat met kwantitatieve methoden de 'oude' problematiek van taalverandering is gaan bestuderen.

Een ander vroeg voorbeeld van een onderzoeksprogramma in de sfeer van de letteren is dat van de iconologie in de kunstgeschiedenis, het programma dat de 'verborgen', 'abstracte' betekenissen van (details van) voorstellingen op prenten en schilderijen in kaart heeft gebracht. Hier geldt Erwin Panofsky (1892-1968) als een van de grondleggers. Het onderzoek van De Jongh en Vinken waarover we in hoofdstuk 6 spraken, behoort tot deze traditie.

We geven hier nog enkele, meer recente voorbeelden van onderzoeksprogramma's in de geesteswetenschappen, die in Nederland zijn of worden uitgevoerd, of in ieder geval ook in Nederland een weerklank hebben gevonden. We maken daarbij geen onderscheid tussen programma's die van tevoren als zodanig zijn bedacht en min of meer planmatig tot uitvoering worden gebracht, en programma's die zonder expliciete programmabeschrijving zijn ondernomen.

- het onderzoeksprogramma van de Universele Grammatica, de beschrijving van de aangeboren principes die een kind in staat stellen een taal te leren;

- het onderzoeksprogramma betrekking hebbend op het onderscheid tussen 'goede' en 'foute' Nederlanders in de Tweede Wereldoorlog, dat een tijdlang de geschiedschrijving van de Tweede Wereldoorlog heeft gedomineerd;

- het zgn. MOLART-programma, voor het onderzoek naar de wijze waarop kunstvoorwerpen (vooral schilderijen) in chemische zin verouderen, en de consequenties ervan voor de praktijk van het restaureren ervan. In dit project werken kunsthistorici en restaurateurs samen met chemici en natuurkundigen;

- het onderzoeksprogramma naar het verzuilingsproces in Nederland;

- het programma 'Reconstructie Nationale Rekeningen en Analyse van de Ontwikkeling van de Nederlandse volkshuishouding', een omvangrijk economisch-historisch programma over de Nederlandse economie in de negentiende eeuw; 
- het onderzoeksprogramma 'De Nederlandse cultuur in Europese Context', een zeer breed opgezet programma naar de wijze waarop sinds de zeventiende eeuw de Nederlandse cultuur invloed heeft ondergaan vanuit de Europese omgeving, en omgekeerd welke invloed de Nederlandse cultuur in het buitenland heeft uitgeoefend.

In Nederland is met name door de overheid de laatste decennia bewust gestreefd naar een vergroting van de schaal waarop het wetenschappelijk onderzoek dient te worden geëntameerd en uitgevoerd. In veel grotere eenheden dan vroeger kent men aan programma's subsidie toe.

7.4

het kruiswoordraadsel als analogie

\section{Susan Haack}

In Evidence and Inquiry (1993) heeft Susan Haack gepoogd een aantal belangrijke wetenschapsfilosofische kwesties, die ook in de voorgaande hoofdstukken aan de orde zijn gesteld, op een consistente wijze met elkaar te verbinden.

Men herinnert zich de observatie van Lakatos, dat wetenschappers in het algemeen als jongleurs verschillende theorieën tegelijkertijd in de lucht proberen te houden. Daarom, zegt Haack, biedt het kruiswoordraadsel een goed vergelijkingsmiddel voor de feitelijke gang van zaken in het wetenschappelijk werk. Het is namelijk een kenmerkende eigenschap van kruiswoordraadsels dat antwoorden op opgaven afhankelijk zijn van antwoorden op andere opgaven. We lossen een kruiswoordraadsel op door een vermoeden van een correct antwoord op een eerste (willekeurige) opgave te verzinnen, en voor dat vermoeden een rechtvaardiging te vinden door vermoedens van correcte antwoorden op kruiswoorden te verzinnen. Kijk naar het bijgaande voorbeeld. Probeer na te gaan welke denkstappen je neemt om een oplossing te vinden voor ieder van de opgaven van de puzzel. Merk op dat zich aan beredenering onttrekt hoe men op een mogelijke goede oplossing komt voor ieder van de opgaven. Dat duo een mogelijk goede oplossing is voor 1. horizontaal, 'daar moet je maar op komen'. Maar hoe dat gaat? De context of discovery blijft een gesloten boek. Maar als men eenmaal het vermoeden heeft dat duo een oplossing zou zijn voor 1. horizontaal, dan kan er voor dat vermoeden steun gezocht worden bijvoorbeeld bij een mogelijke oplossing voor 1. verticaal. Duo staat sterker, als 1. verticaal met een [d] begint. Het zou den kunnen zijn. Verdere steun verwerft $d u o$, als 2. verticaal met een $[\mathrm{u}]$ begint, etc. Het vermoeden dat den een mogelijke oplossing is voor 1. verticaal hangt af van de steun die voor de $[e]$ wordt ontleend aan 2. horizontaal waarvoor eega als oplossing kan worden voorgesteld. Maar als 1. horizontaal nu eens dek zou zijn? De werkwoorden paren en dekken zijn toch synoniem? 


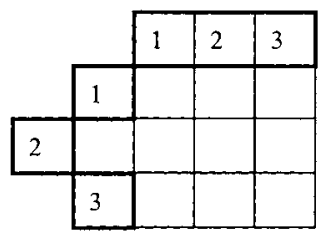

Horizontaal

1. paar

2. gehuwde vrouw

3. vrouwelijke ontkenning
Verticaal

1. lidwoord met naalden

2. eigendunk

3. mogelijke vloeistofdrager

1. horizontaal is dubbelzinnig zolang er geen samenhang is bereikt. Bij het oplossen van een kruiswoordpuzzel wordt er niet alleen gezocht naar een correct antwoord op ieder van de opgaven, maar ook naar coherentie tussen het totaal van de antwoorden. De hele puzzel is goed opgelost als er een coherent geheel ontstaat waarvan alle onderdelen een aanvaardbaar antwoord zijn op de in de redactie gestelde opgave. Uiteindelijk kan de oplossing van de gehele puzzel correct heten, maar dat betekent in principe niet dat er geen andere eveneens correcte oplossing van de gehele puzzel is. Een tweede correcte oplossing voor de hele puzzel zou een toeval zijn, maar kan niet worden uitgesloten. Een verificationistische houding ten opzichte van kruiswoordraadsel-oplossingen is onjuist.

We hebben er al op gewezen dat de analogie van de kruiswoordpuzzel verhelderend kan zijn met betrekking tot de kwestie van de onzekerheid van woordbetekenissen. De mogelijke meerzinnigheid die aan woordbetekenissen eigen is, kan worden bezworen door het netwerk van andere woorden waarin een woord functioneert. De context, de andere woorden, bepalen gedeeltelijk welke interpretatie in een concreet geval zal moeten worden gekozen. Net zoals de oplossing van de ene opgave in een kruiswoordpuzzel mede wordt bepaald door de oplossingen van andere opgaven en omgekeerd.

De parallellie met het wetenschappelijk onderzoek is, denken we, eveneens helder. Het komt er bij het toetsen van een theorie niet alleen op aan steun te vinden in de feiten, door toetsing van de theorie. Steun voor een theorie kan ook gevonden worden in de samenhang. Een vermoeden wordt niet alleen gerechtvaardigd door correspondentie met de werkelijkheid, maar ook door samenhang met andere vermoedens, waarvoor ook gedeeltelijk onafhankelijke steun in de werkelijkheid $\mathrm{kan} /$ moet worden gevonden, zodat er geen cirkelredenering ontstaat. Daarom ook zijn ad hoc-theorieën waardeloos.

foundationalisme vs.

Haack probeert een verzoening tot stand te brengen tussen twee gecoherentisme zichtspunten ten aanzien van de rechtvaardiging van kennis. De eerste staat bekend onder de naam foundationalisme en de andere onder de 
Haacks rechtvaardigingstheorie naam coherentisme. Een foundationalistische visie zegt, zoals we gezien hebben, dat de enige manier om een bepaald vermoeden bevestigd te krijgen is: uit dit vermoeden 'basisvermoedens' af te leiden die aan de werkelijkheid getoetst kunnen worden; en het is in principe mogelijk de correspondentie van basisvermoeden en werkelijkheid objectief vast te stellen. De rechtvaardiging van zo'n basisvermoeden steunt niet op reeds gerechtvaardigde andere vermoedens. In enige vorm hebben erg veel wetenschappers dit soort foundationalistische ideeën: mijn waarnemingsvermogen en de verwoording van mijn vermoeden laten me niet in de steek; de werkelijkheid doet zich niet dubbelzinnig aan me voor. Maar in hun dagelijkse werk zullen ze ook naar samenhang van hun theorieën of vermoedens met andere theorieën zoeken, of zullen ze tevreden zijn, als hun theorie in een patroon van andere theorieën blijkt te passen. Dit laatste is typerend voor de coherentistische visie op de rechtvaardiging van kennis. Zo'n visie kan het beste omschreven worden als het idee dat een vermoeden (een theorie) gerechtvaardigd is als die behoort tot een coherente verzameling van andere theorieën/vermoedens. De overeenkomsten van het foundationalisme enerzijds en het coherentisme anderzijds met resp. de correspondentietheorie en de coherentietheorie van waarheid springen in het oog. Het verschil is dat het in de beide eerste gevallen gaat om theorieën over de wijze waarop kennis kan worden onderbouwd, terwijl de laatste twee theorieën betrekking hebben op het begrip 'waarheid'.

Haack noemt haar eigen opvatting foundherentism. Die term vinden wij te kunstmatig om over te nemen. In plaats daarvan zullen we spreken over Haacks rechtvaardigingstheorie. Haacks theorie omvat het idee dat een theorie meer of minder gerechtvaardigd kan heten. Er zijn gradaties in de zekerheid waarmee wetenschappelijke vermoedens voor juist worden gehouden. Dat is zeker in overeenstemming met de ervaring van de wetenschap van alledag. Er zijn vaak voor een opvatting meer of minder sterke argumenten beschikbaar; en ook al laten we ons ook niet door een sterk argument steeds compleet overtuigen, toch maken we onderscheid tussen sterke en zwakke argumenten. Iemand die het vermoeden heeft dat de benzinetank van de auto binnen vijftig kilometer leeg zal zijn en dat het dus verstandig is een tankstation op te zoeken, kan zo'n vermoeden beter onderbouwen met te wijzen op de stand van de benzinemeter in de auto, dan met het argument dat haar levensgezel al een paar dagen een voorgevoel heeft dat ze vandaag wel eens pech zou kunnen krijgen. Het eerste argument is sterker omdat dit samenhangt met aanvaarde andere theorieën met betrekking tot de werking van onderdelen van auto's, terwijl dat van het andere niet het geval is.

Verder omvat Haacks rechtvaardigingstheorie de veronderstelling dat een bijdrage aan de rechtvaardiging van een theorie geleverd kan worden 
groei van kennis en Haacks rechtvaardigingstheorie zowel door er een basisuitspraak uit af te leiden die aan de werkelijkheid wordt getoetst, als door de samenhang met al of niet gedeeltelijk gerechtvaardigde andere theorieën.

Hoewel Haack zich in Evidence and Inquiry over de groei van kennis niet uitlaat, is wel duidelijk hoe groei van kennis in dat kader moet worden begrepen. Aangezien een vermoeden en de mogelijke rechtvaardiging ervan nooit alleen komen, groeit kennis door een uitbreiding van het netwerk van samenhang tussen verschillende theorieën. Anders dan een echte kruiswoordpuzzel zijn de werkelijkheid en de kennis over de werkelijkheid niet begrensd. We kennen niet bij voorbaat het aantal vakjes dat door een theorie moet worden ingevuld, en dus ook niet het antal 'kruiswoorden' dat een theorie met andere theorieën zou kunnen vertonen. Uitbreiding van de samenhang tussen theorieën kan tot stand komen door de opheffing van tegenspraak, dat wil zeggen door de opheffing van inconsistenties. Het is niet moeilijk om in te zien dat dit precies is wat we doorgaans het oplossen van een probleem noemen: het oplossen van een vermeende tegenspraak tussen vermoedens of theorieën. Een probleemstelling is een beschrijving van zo'n inconsistentie.

Merk op dat men - net als bij de oplossing van een kruiswoordraadsel - niet de zekerheid heeft dat de gevonden oplossing van een probleem de enig juiste is. Anders echter dan bij het kruiswoordraadsel kunnen onder sommige omstandigheden twee gevonden oplossingen worden vergeleken aangaande de omvang van de samenhang die ze bewerkstelligen. Dit is een gevolg van het feit dat kennis in beginsel onbeperkt uitbreidbaar is, en de gezochte samenhang dus in beginsel onbeperkt omvangrijk. Al eerder stelden we vast dat voor wetenschappen waarin het zoeken van een samenhang op de voorgrond treedt, vaak de breedte van de samenhang een argument is voor de kwaliteit ervan.

Kan een samenhang, een verzameling beweringen waarvan er geen strijdig is met de ander, worden weerlegd? Niet in die zin dat als gevolg van de weerlegging geen van de beweringen die in de samenhang betrokken waren nog samenhangt met enige andere. Maar net als het bij een kruiswoordraadsel denkbaar is dat een succesvol ingevulde linkerbovenhoek van de puzzel, toch fouten vertoont op grond van de oplossing van de rest van de puzzel, hetgeen pas aan het licht komt als gepoogd wordt een contact tussen de beide hoeken van de puzzel tot stand te brengen, en de samenhang in de linkerbovenhoek dus niet beslissend is, zolang de rest niet eveneens in de samenhang is opgenomen; zo kan ook een samenhang in een deelgebied van de kennis toch niet correct blijken, in het licht van de kennis van een andere samenhang die kennelijk beter is gefundeerd. 
veelomvattende theorieën in de letteren
Geïnspireerd door deze kennismaking met opvattingen over de groei van kennis die voornamelijk zijn afgeleid uit een analyse van aspecten van de natuurwetenschappen en de sociale wetenschappen, buigen we ons nu over de groei van kennis in de letteren.

Er zijn weinig voorstudies op dit gebied. Men vindt wel her en der impressies van allerlei aard. Er zijn cynici die aan het rationele karakter van hun vak twijfelen, en dus aan de vooruitgang. Er zijn relativisten die de opvatting delen dat ieder nieuw gezichtspunt 'moet kunnen' en dus in alles of niets vooruitgang zien. Er zijn optimistische goudzoekers die subsidiegevers wezenlijke vooruitgang in het vakgebied beloven, en daar zelf een tijdje in geloven. Hoe krijgen we hier vaste grond onder de voeten?

Als we groei van kennis willen vaststellen, zullen we vooral moeten zoeken op plaatsen waar gewerkt wordt aan verdieping van theoretische kennis, en plaatsen waar sprake is van een toename van samenhang tussen kennisgebieden. We wenden ons eerst tot 'theorievorming'.

Werken aan een of meer theorieën zoals bedoeld door Popper en Lakatos is in grote delen van de letteren onbekend. Alleen in de taalkunde bestaat een situatie die vergeleken kan worden met die in de natuur- en levenswetenschappen waar relativiteitstheorie of evolutietheorie grote delen van het onderzoek domineren. Bij de taalkunde wordt die rol vervuld door de theorie van de Universele Grammatica, waarvan de Amerikaan Noam Chomsky de grondlegger is.

We vinden hier een grote groep onderzoekers die talloze aspecten van het menselijk taalvermogen bestudeert met als leidende gedachte dat een klein kind een taal leert in een omgeving die het taalsysteem slechts in een armoedige incomplete vorm aan het kind aanbiedt. De theorie van de Universele Grammatica zegt dat een kind daarin slaagt omdat het geboren wordt met hersenen waarin dit taalvermogen is ingeweven. Het aangeboren taalvermogen bepaalt de algemene eigenschappen van alle talen die een mens op een natuurlijke wijze kan leren. Dit gaat lijnrecht in tegen empiristische leertheorieën die zeggen dat een kind met een 'lege geest', een 'tabula rasa' ter wereld komt en dat alle kennis door zintuiglijke ervaringen wordt verworven.

De theorie van de Universele Grammatica heeft daarmee ook grote delen van de psychologie en de cognitiewetenschappen diepgaand beïnvloed. Hij is ook in die zin vruchtbaar gebleken dat het idee van de aangeboren vermogens ook voor andere hersenfuncties tot nieuwe inzichten aanleiding heeft gegeven: bijvoorbeeld op het gebied van de visuele waarneming, en de muziekwaarneming.

Het theoretische raamwerk van de Universele Grammatica laat de afleiding toe van allerlei deeltheorieën, die aan intuïties, het gebruikelijke 
sommige wetenschappen worstelen met het begrip theorie

theorievorming in de andere geesteswetenschappen

de Sokal-mystificatie empirisch materiaal, kunnen worden getoetst. 'Er zijn hier', zegt de Nederlandse linguïst Jan Koster, 'wezenlijke resultaten geboekt, en wel op een cumulatieve manier (als in de natuurwetenschappen) en niet volgens een opeenvolging van modes [...]' (1997: 60)

De vooruitgang is hier steeds bepaald door nieuwe theoretische raamwerken die uit de bestaande worden ontwikkeld. In de periode die op de publicatie van het nieuwe raamwerk volgt wordt het door nieuw empirisch materiaal verder onderbouwd en ... ondergraven.

Men treft bij de geesteswetenschappen wel vaker 'theorieën'. Maar die hebben eerder een functie als onderzoekskader of visie of reflectie op een praktijk. Te denken valt aan de receptietheorie in de kunstwetenschappen, de theorie van de integrale geschiedschrijving, de verteltheorie, de semiotiek of een interpretatietheorie als het deconstructivisme. Die theorieën lenen zich niet voor de afleiding van toetsbare hypothesen. Maar ze hebben wel nieuw onderzoek uitgelokt. Ze leveren nieuw conceptueel gereedschap. Tot zover over geesteswetenschappelijke theorievorming en de mogelijkheid in deze theorievorming groei van kennis in de zin van Popper of Lakatos aan te tonen.

Soms zoeken onderzoekers in de geesteswetenschappen bij gebrek aan eigen 'grand theories' steun bij invloedrijke filosofische stelsels. Dat blijkt uit de lijst (uit 1987) van de vijftig publicaties waarnaar tussen 1976 en 1983 door onderzoekers op het gebied van de humaniora het meest werd verwezen. Opvallend is de ruime aandacht die het werk van filosofen ten deel valt, zoals Foucault, Derrida, Habermas, Marx, Freud, Gadamer, Sartre, Lacan, Merleau-Ponty. Zie tabel 3.

Ook voor dit soort stelsels geldt: wat hier theorie wordt genoemd, is veel eerder een gezichtspunt van waaruit een deel van de werkelijkheid kan worden bekeken. Het zijn visies, strategieën voor onderzoek, wetenschappelijke stromingen, reflecties op een praktijk, maar geen verzamelingen toetsbare hypothesen. Dat hier sprake kan zijn van 'modes' kan blijken uit een staatje waarin over bijna twee decennia de populariteit van leidende auteurs is uitgezet. Net als tabel 3 is ook dit staatje gebaseerd op de frequenties waarmee in publicaties van geesteswetenschappelijke (A\&HCI) en sociaal-wetenschappelijke aard, naar het werk van de genoemde auteurs wordt verwezen. De veranderingen in de populariteit van Marx, van Foucault en van Derrida kan men uit dit staatje goed aflezen. Zie tabel 4 .

Het modieuze, vaak politieke karakter van deze oriëntaties heeft troebel water gecreëerd waarin het voor sommigen goed vissen was. Een voorbeeld is de mystificatie van Alan Sokal. 
Meest geciteerde auteurs in de geesteswetenschappen

855 Kuhn, The structure of scientific revolutions. 1962

710 Joyce, Ulysses. 1922

699 Frye, Anatomy of criticism. 1957

668 Wittgenstein, Philosophische Untersuchungen. 1953

640 Chomsky, Aspects of the theory of syntax. 1965

488 Foucault, Les mots et les choses. 1966

475 Derrida, De la grammatologie. 1967

454 Barthes, S/Z. 1970

$450 \quad$ Heidegger, Sein und Zeit. 1927

434 Curtius, Europäische Literatur und lateinisches Mittelalter. 1948

426 Gadamer, Wahrheit und Methode.1960

418 Rawls, A theory of justice. 1971

416 Joyce, Finnegans wake. 1939

415 Searle, Speech Acts. 1969

411 Culler, Structuralist poetics. 1975

400 Genette, Figures. 1966

399 Chomsky en Halle, The sound pattern of English. 1968

378 Austin, How to do things with words. 1962

378 Eliot, The waste land. 1922

370 Quine, Word and Object.1960

366 Proust, A la recherche du temps perdu. 1914 etc.

346 Wittgenstein, Tractatus logico-philosophicus. 1922

345 Joyce, Portrait of the artist as a young man. 1916

336 Booth, The rhetoric of fiction. 1961

335 Lévi-Strauss, Anthropologie structurale. 1958

331 Freud, Die Traumdeutung. 1900

319 Propp, The morphology of the folktale. 1928

297 Saussure, Cours de linguistique générale 1915

293 Sartre, L'être et le néant. 1943

292 Kripke, Naming and necessity. 1972

290 Benveniste, Problèmes de linguistique générale. 1966

286 Popper, Conjectures and refutations. 1963

280 Lacan, Ecrits. 1966

272 Derrida, L'écriture et la difference. 1967

272 Chomsky, Syntactic structures. 1957

262 Jakobson, Closing Statement: linguistics and poetics. 1960

255 Hirsch, Validity in interpretation. 1967

253 Lévi-Strauss, La pensée sauvage. 1962

245 Pound, The cantos. 1925

244 Berger en Luckmann, The social construction of reality. 1966

244 Bakhtin, Rabelais and his world. 1965

236 Iser, Der Akt des Lesens. 1976

236 Merleau-Ponty, Phénoménologie de la perception. 1945

235 Eco, A theory of semiotics. 1976

235 Popper, Objective Knowledge. 1972

235 Auerbach, Mimesis. 1946

234 Gombrich, Artand illusion. 1960

228 Thompson, The making of the English working class. 1964

226 Habermas, Erkenntnis und Interesse. 1968

225 Popper, Logik der Forschung. 1935

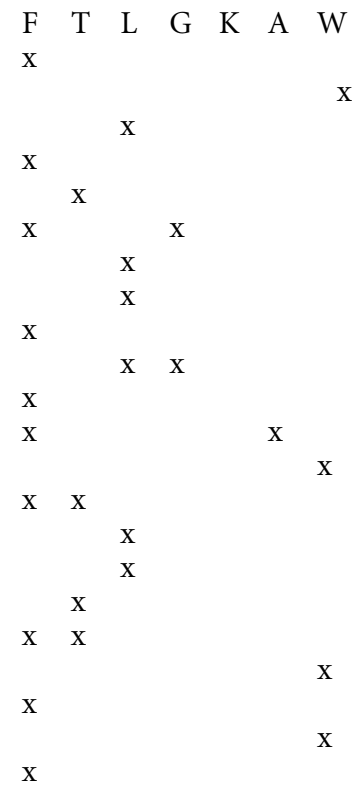

$\mathrm{X}$

$\mathrm{X}$

$\mathrm{X}$

$\mathrm{X}$

$\mathrm{x}$

X

$\mathrm{X}$

$x \quad x$

$\mathrm{X}$

$\mathrm{X}$

$\mathrm{X}$

$x$

X

$x$

$\mathrm{x}$

$\mathrm{X}$

$\mathrm{X}$

X

X

X

$\mathrm{X}$

X

X

X

X

$\mathrm{X}$

Tabel 3 Lijst van de 50 publicaties op het gebied van de geesteswetenschappen die in de periode 19761983 het meest werden geciteerd (naar Garfield 1987, 8-9) F=filosofie; T=taalkunde; L=literatuurwetenschap; $\mathrm{G}=$ geschiedenis; $\mathrm{K}=$ kunstgeschiedenis; $\mathrm{A}=$ ander wetenschapsgebied; $\mathrm{W}=$ literair werk. De twee tijdschriftartikelen zijn onderstreept. 


$\begin{array}{lcccccccccc} & 1980-1989 & 1990 & 1991 & 1992 & 1993 & 1994 & 1995 & 1996 & 1997 & 1997 \\ \text { Gadamer } & 162 & 177 & 220 & 228 & 165 & 160 & 168 & 179 & 185 & (115) \\ \text { Marx } & 634 & 369 & 370 & 384 & 347 & 280 & 260 & 249 & 219 & (325) \\ \text { Weber } & 203 & 181 & 251 & 303 & 278 & 254 & 214 & 217 & 205 & (617) \\ \text { Habermas } & 230 & 278 & 368 & 439 & 374 & 373 & 342 & 333 & 303 & (519) \\ \text { Bourdieu } & & & & & & & 302 & 332 & 358 & (617) \\ \text { Foucault } & 391 & 490 & 671 & 816 & 785 & 758 & 798 & 785 & 800 & (807) \\ \text { Derrida } & 352 & 495 & 599 & 616 & 523 & 529 & 581 & 575 & 577 & (216)\end{array}$

Tabel 4 Aantallen citaties per jaar of groep van jaren (1980-1997) voor verschillende auteurs in A\&HCI en (tussen haakjes) de cijfers voor 1997 in de Social Science Citation Index.

Naar mijn mening verhindert het gebruik van zulke onderzoekskaders een serieuze analyse van groei of vooruitgang. Het is niet verwonderlijk dat de onderzoekers veelal het gedachtegoed van het relativisme omhelzen, en menen dat Kuhn het grootste gelijk van de wereld heeft.

groei van kennis door

Wenden we ons nu tot 'groei van kennis' die bestaat in het vergroten het vergroten van 'samenhang' van 'samenhang'. We sluiten aan bij de opvattingen van de historicus Den Boer (1990: 62-64). Den Boer onderscheidt vier manieren waarop de historische wetenschappen zich kunnen vernieuwen.

vier typen historische - nieuwe data;

innovatie

- nieuwe methoden en technieken;

- nieuwe concepten;

- nieuwe visies.

nieuwe ontdekkingen

We lopen deze typen innovaties na, en bezien wat er in termen van 'groei van kennis' over kan worden opgemerkt. Den Boer noemt als 'eclatante voorbeelden'van nieuwe ontdekkingen

de verlenging van ons verleden door de prehistorische vondsten, door opgravingen van verzonken beschavingen, maar ook door ontcijfering van raadsels, zoals bijvoorbeeld van de hiëroglyfen door Champollion in 1822.

De voorbeelden zijn overtuigend. Het beschikbaar komen van 'nieuw' archiefmateriaal en de analyse ervan hoort ook in deze categorie thuis. Nieuw empirisch materiaal maakt 'nieuwe kennis' mogelijk. Het materiaal is zelf niet te zien als een weerlegging van oude theorieën maar het maakt toetsing ervan mogelijk, en de creatie van nieuwe samenhangen. 


\section{Michel Foucault (1926-1984)}

Foucault, Frans filosoof, behoort tot de invloedrijkste schrijvers van de tweede helft van de twintigste eeuw.

Hij heeft zich vooral met historische onderwerpen beziggehouden, speciaal met de geschiedenis van het denken in de zeventiende, achttiende en negentiende eeuw. Het bracht hem tot filosofische en politieke conclusies die in het bijzonder de positie van de wetenschappen in de moderne samenleving raken. Hij had een bijzondere belangstelling voor de vraag hoe de sociale wetenschappen zich uit het klassieke denken hebben ontwikkeld. Hij analyseerde bijvoorbeeld de ideeën over wat we waanzin of gestoord gedrag noemen, over de manier waarop de samenleving misdadigers bestraft, over taal, over de biologische soorten en over de economische welvaart. Dit denken lokaliseerde hij in het taalgebruik van de onderzoekers. Foucault gebruikt het Franse woord 'discours'. Onder Nederlandse volgelingen is daarvoor het woord 'vertoog' in gebruik geraakt.

De filosofische boodschap is deze. Kennis over de mens is het gevolg van het uitoefenen van macht. De mensen zoeken niet als vrije nieuwsgierige onderzoekers naar de waarheid. Wat waarheid is, wordt bepaald door macht en de spraakmakende machthebbers. Hun taal stuurt de richting van het denken, en bepaalt wat mensen als waarheid zien. Het wetenschappelijke streven om de waarheid te achterhalen is voor Foucault iets gevaarlijks. Het leidt tot uitsluiting van soorten kennis die zich niet op (wetenschappelijke) waarheid richten.

Het is waarschijnlijk de politieke inbedding die Foucault bij 'linkse' academici in Amerika tot een populaire geesteswetenschapper heeft gemaakt. Zijn denken lijkt de gedachte te voeden dat wetenschap bedreigend is.

Foucaults werk is in de wetenschappen buitengewoon omstreden. Als onderzoeker doet hij bijna alles wat God en de wetenschappelijke methode verboden hebben.

Er is geen bronnenkritiek noch verantwoording van de selectie van de bronnen. Het empirisch materiaal is beperkt. Hij schrijft soms ondoorgrondelijk. Hij gebruikt beeldspraak die verwarring zaait. Cruciale termen betekenen niet steeds hetzelfde. Er ontstaat geen toetsbaar theoretisch kader. Hij plaatst zich buiten de traditie van het onderzoek op de terreinen van de geschiedenis van de empirische wetenschappen waar hij over schrijft.

Bronnen: Foucault, De orde van het spreken (inl. en vert. Thomas Widdershoven); Foucault, Discipline and punishment; Foucault, De woorden en de dingen; een archeologie van de menswetenschappen (vert. C.P.HeeringMoorman) 
nieuwe methoden en technieken
Men denke aan de wetenschappelijke vooruitgang die tot stand kwam in de tijd van het humanisme, toen zoveel klassieke teksten weer onder het stof der eeuwen vandaan werden gehaald. Men kan ook denken aan de ontdekking van de Dode Zee-rollen die een compleet nieuw beeld mogelijk maakten van de ideologische basis van het vroege christendom. In het veld van de kunstwetenschappen is de recente herontdekking van het artistieke werk van veel vrouwelijke kunstenaars een ander spectaculair voorbeeld. Deze wijze van vernieuwing illustreert het enorme belang dat de geschiedbeoefening hecht aan de beschikbaarheid van archieven.

Over het belang van nieuwe methoden en technieken hebben we al eerder gesproken. Of ze nu in de geesteswetenschappen ontwikkeld zijn of aan andere vakgebieden worden ontleend, ze kunnen tot een onbetwistbare uitbreiding van kennis leiden. Den Boer doelt vooral op kwantificatie.

\section{De Sokal-mystificatie}

In 1996 publiceerde de Amerikaanse fysicus Alan Sokal een artikel in Social Text, een Amerikaans tijdschrift met een linkse, postmoderne reputatie. Het artikel had een fancy titel: 'Transgressing the boundaries: towards a transformative hermeneutics of quantum gravity'. Het artikel was een grap: het was van het begin tot het eind samengesteld uit zinsneden en jargon ontleend aan de filosofieën die bij sommige sociale wetenschappers en geesteswetenschappers hoog staan aangeschreven. Het maakt gebruik van alle elementen die in de 'wetenschappelijke' mode zijn: interdisciplinariteit, postmodernisme, hermeneutiek, kwantumtheorie, en taal, veel taal. Sokal hutseklutste daar een onbegrijpelijk quasi-filosofisch verhaal van, dat door de redactie voor een bijdrage aan de wetenschap werd gehouden. Nadat Sokal zijn mystificatie had onthuld, trok de geschiedenis overal ter wereld grote aandacht. Men kan een deel van de discussie terugvinden op Sokals homepage <http://www.physics.nyu.edu/faculty/so$\mathrm{kal} / \#$ papers $>$. Sokal had een gevoelige snaar geraakt. Het opzienbarende is niet zozeer dat Sokal zijn stuk gepubliceerd kreeg. Social Text kan nauwelijks een serieus wetenschappelijk tijdschrift heten. Het komt bijvoorbeeld niet voor in de bronnenlijsten van de Social Science Citation Index of de Arts\&Humanities Citation Index. Het is veeleer de opschudding zelf, die er op wijst dat in de mening van opiniemakers de geesteswetenschappers (en sociale wetenschappers) wat al te gemakkelijk hun oor lenen aan speculatieve filosofieën die geen aanleiding zijn voor empirische toetsing. 
nieuwe concepten

nieuwe visie

is innovatie van

kennis ook groei van kennis?
De kwantificatie is, vanaf het einde van de negentiende eeuw aarzelend beginnend, de innovatie bij uitstek. De Russische historicus Loutchisky sprak aan het einde van de vorige eeuw, toen nog geen Franse historicus sommen maakte, van de noodzaak om de ideeën te preciseren door approximatieve percentages.

Kwantitatieve methoden en technieken zijn de laatste decennia in de geesteswetenschappen aan een opmars bezig. In samenhang met de zoektechnieken die door de computer worden geleverd, leidt dat tot veel nieuwe inzichten.

De vernieuwing door de toepassing van nieuwe begrippen illustreert Den Boer als volgt:

Een [...] voorbeeld is François Simiand (1932) die het begrip conjunctuur uit de economische wetenschap in de geschiedenis introduceerde en voor het eerst enkele eeuwen economisch verleden in een conceptueel verband plaatste: een fase A, een periode van expansie waarin onder invloed van de toevoer van edel metaal de prijzen stijgen en de lonen toenemen, gevolgd door een fase B, een periode van recessie, gekenmerkt door monetaire honger, dalende prijzen en verminderende lonen.

Nieuwe begrippen zijn dragers van nieuwe onderscheidingen. De invoering van nieuwe begrippen brengt een nieuwe kijk op of een nieuwe ordening van de werkelijkheid met zich mee.

Innovatie in de vorm van een nieuwe visie op een bekend complex van gegevens licht Den Boer als volgt toe.

Een beroemd voorbeeld is de Herfsttij der Middeleeuwen van Huizinga. De veertiende en vijftiende eeuw - en met name de kunst der Van Eycks - werden door hem niet gezien als een aankondiging van de Renaissance maar als een slotfase van de Middeleeuwen.

Huizinga's boek wordt algemeen gerekend tot de hoogtepunten van het Nederlands historisch onderzoek. Ook zonder expliciete 'falsificatie' van de oude visie kan de nieuwe gezien worden als samenhang van een reeks bekende observaties (betreffende de kunst van de gebroeders Van Eyck), die beter passen bij andere observaties die tot dan toe onbekend waren of niet met de kennis over de Van Eycks in verband waren gebracht. Het beschikbaar komen van de nieuwe visie is te zien als een vooruitgang in de zin van uitbreiding van bestaande kennis.

Vernieuwing is wel een noodzakelijke, maar niet een voldoende voorwaarde voor het benaderen van de waarheid. Ook de kunsten, de mode, 
is een nieuwe visie ook groei van kennis?

bij gevoelige onderwerpen zal de nieuwe samenhang ook de bekende feiten omvatten

het begrip 'gezaghebbende publicatie' de taal, de omgangsvormen vernieuwen zich steeds, zonder dat er van vooruitgang sprake hoeft te zijn.

Wijzen de innovaties die Den Boer noemt, ook op groei? Om van vooruitgang te kunnen spreken is het minimaal ook nodig dat aangegeven wordt op welke punten de nieuwe visie strijdig is met de tot dan toe aanvaarde standpunten, en waarom de nieuwe visie beter is dan de oude. Daarvoor is nodig dat aangetoond wordt dat de nieuwe visie meer/beter correspondeert met de bekende feiten en/of dat de nieuwe kennis meer samenhang vertoont met andere kennis. Zulke demonstraties worden in die geesteswetenschappen waar theorievorming een geringe rol speelt, zelden ondernomen.

Dit heeft te maken met het volgende. De alfavakken zijn niet zozeer probleem-georiënteerd zijn, als wel onderwerp-georiënteerd. Aan veel publicaties in de humaniora stelt men tevergeefs de vraag: 'wat is het probleem waarop een antwoord wordt gezocht? Wat zijn de feiten of wat zijn de theoretische inzichten die zich niet laten verenigen met bestaande kennis?' In plaats daarvan bewerkt men een onderwerp. Dit punt is in kritische zin naar voren gebracht in Berkson (1995). Een hergroepering van een deel van de oude feiten met nieuwe kan zo een nieuw onderzoeksresultaat opleveren. Een verbreding is het resultaat, maar niet noodzakelijkerwijs een verdieping van kennis, omdat niet alle 'oude' feiten in de nieuwe samenhang meedoen. Waar het in de geesteswetenschappen niet om verdieping van de theoretische inzichten gaat, is er geen reden om van een nieuw werk te eisen dat het minimaal recht doet aan de 'oude' feiten.

Er zijn situaties waarin dit wel zal moeten worden nagestreefd. Soms moeten geesteswetenschappers politiek gevoelige onderwerpen behandelen. Of onderwerpen waar veel geld mee gemoeid is. Dat is zo als historici bijvoorbeeld wordt gevraagd een oordeel te vellen over verschillende facetten van de rol van Nederlandse militairen bij de val van Srebrenica, of over de afwikkeling van Joodse financiële zaken als nasleep van de Tweede Wereldoorlog; of als kunsthistorici uitsluitsel moeten geven over de authenticiteit van bijvoorbeeld de aan Rembrandt toegeschreven schilderijen. In zulke gevallen is wel degelijk sprake van een vermoeden van strijdigheid van feiten en/of theorieën, dus van problemen. De nieuwe samenhang zal dan geloofwaardig zijn als ook alle 'oude' feiten recht gedaan wordt in de nieuwe samenhang. In zulke gevallen zal van 'groei van kennis' worden gesproken.

In de bedoelde sectoren van de letteren kan de groei van kennis dus niet in termen van theorieën, paradigmata of onderzoeksprogramma's worden beschreven. Wij denken dat het realistischer is groei van kennis in de letteren te beschrijven in termen van de opvolgende reeksen van 'gezaghebbende publicaties', die hoe langer hoe meer recht zullen doen 
kenmerken van

gezaghebbende

publicaties

groei van kennis in termen van gezaghebbende publicaties

het verouderen van gezaghebbende publicaties aan meer bekende feiten. Daarbij willen we aansluiten bij een idee van Hayden White die over de geschiedbeoefening opmerkt: '[...] history progresses by the production of classics [...].' (geciteerd bij Ankersmit 1990: 43)

Ieder onderzoeksgebied kent voor een reeks van onderwerpen zulke gezaghebbende publicaties. Het zijn boeken of artikelen die door een onderzoeker niet kunnen worden veronachtzaamd, omdat ze de stand van kennis op een onderzoeksterrein het beste representeren. Iedere onderzoeker accepteert een aantal publicaties op het onderzoeksgebied als gezaghebbend. Het zijn in feite deze gezaghebbende publicaties die overtroffen, verbeterd of aangevuld moeten worden in een nieuwe publicatie. Iemand die een bepaald onderwerp wil bestuderen, zal zich daarom oriënteren op publicaties waarin globaal de relevante stand van kennis en de theorievorming het beste is beschreven. Als het goed is, maken studenten in hun studieboeken kennis met deze publicaties. Tijdschriftpublicaties leveren het materiaal op basis waarvan op den duur een nieuwe gezaghebbende studie wordt geschreven. De geschiedschrijving van een vakgebied zal gezaghebbende publicaties als mijlpalen in de ontwikkeling van dat vakgebied behandelen.

Men kan van de opeenvolging van gezaghebbende publicaties op een onderzoeksterrein soms een indruk krijgen door de literatuurverwijzingen van een encyclopedie te raadplegen. Het tempo van de ontwikkelingen zou afgelezen kunnen worden aan de tijd die verloopt tussen het aantal gezaghebbende publicaties over een bepaald onderwerp. Het versplinterde, veelkleurige karakter van de geesteswetenschappen komt goed tot uitdrukking in het bestaan van grote aantallen gezaghebbende publicaties. Het kennisbeheer van de geesteswetenschappen vindt voor een belangrijk deel daarin zijn uitdrukking.

De gezaghebbende publicaties zijn vaak bestemd voor een groter publiek dan de onderzoekers zelf, maar kunnen moeilijk als vereenvoudigde populariseringen van kennis worden beschouwd. (RAWB 1990: 11n)

Kan een gezaghebbende publicatie zijn gezag verliezen? Hayden White meent van niet, getuige het vervolg van het zojuist gepresenteerde citaat: '[...] history progresses by the production of classics, the nature of which is that they cannot be disconfirmed or negated in the way the principal schemata of the sciences are.' Inderdaad: een nieuwe gezaghebbende publicatie zal zich in het algemeen niet hierin van zijn voorganger onderscheiden dat de oude kennis door de nieuwe geheel wordt weerlegd. Maar dat neemt niet weg dat een gezaghebbende publicatie kan verouderen omdat er feiten of inzichten aan het licht zijn gekomen die in die publicatie niet waren geïntegreerd.

Gezaghebbende publicaties lenen zich voor aanvulling en uitbreiding; ze kunnen na verloop van tijd verouderd blijken en ook (soms) 
groei in de geesteswetenschappen? gedeeltelijk weerlegd. Ze kunnen verouderen doordat nieuwe feitenverzamelingen, nieuw archiefmateriaal of nieuwe waarnemingstechnieken beschikbaar zijn gekomen. Ze kunnen gedeeltelijk weerlegd worden als ze een oplossing van een probleem presenteren die zich op den duur slecht blijkt te laten verenigen met sterk gerechtvaardigde inzichten die in samenhang met de eerste moeten worden gedacht.

Publicaties die eens gezaghebbend waren, worden vaak niet weerlegd, maar raken langzamerhand versleten: er komen nieuwe feiten en inzichten; op deelgebieden is de samenhang voor verbetering vatbaar; er is gebleken dat de auteur hier en daar een foute redenering heeft gebruikt etc. In het al eerder gepresenteerde citaat van Bommeljé over de wijze waarop de feitelijke werkwijze van de historici in Poppers ideeën gereflecteerd wordt, is goed tot uitdrukking gebracht hoe men zich dit proces ongeveer moet voorstellen.

Stel dat een ontwikkeling op een onderzoeksterrein in de geesteswetenschappen te karakteriseren is als een elkaar opvolgende reeks van gezaghebbende publicaties op dat terrein van onderzoek. Is dit ook 'groei' van kennis? Dit zou het geval zijn als aangetoond zou kunnen worden dat hoe langer hoe grotere hoeveelheden verzamelingen feiten en visies met elkaar in een samenhangend verband zouden kunnen worden gebracht. Het is denkbaar dat zulks voor een werkelijkheidsgebied zou kunnen worden ondernomen. Maar het is evident dat het praktisch onmogelijk is op dit moment om het ontbreken van strijdigheden in een verzameling van enige omvang aan te tonen. Het is dan ook geen wonder dat men van onderzoekers in de geesteswetenschappen zowel de impressie kan horen dat iedere tijd zijn eigen wetenschap schept zonder te laten zien in welk opzicht de nieuwe kennis superieur is aan die van vroeger tijden, terwijl anderen zeggen, wijzend op toename van publicaties en verbetering van waarnemings- en zoektechnieken, dat ze de stellige indruk hebben dat de kennis in de wetenschappen die niet achter de waan van de dag aanlopen, accumuleert. 


\section{8}

recapitulatie

\section{De waarde van kennis}

Het produceren van objectieve kennis over taal, letterkunde, de kunsten en het verleden mag dan het doel zijn van de cultuurwetenschappen, we hebben geconstateerd dat beperkingen zijn gesteld aan de realisering van dat doel. We sommen hier bij wijze van recapitulatie zes van deze beperkingen nog eens op.

- We kunnen niet theorie-vrij observeren. We kunnen niet waarnemen als een onbeschreven blad. De waarneming is gekleurd door het natuurlijk kenvermogen van het kennend subject. Soms wordt de waarneming door het gebruik van waarnemingsinstrumenten scherper en gedetailleerder. De theoriegebondenheid van de waarneming wordt dan gedeeltelijk verlegd naar de theorie die in het waarnemingsinstrument besloten ligt.

- We kunnen niet theorie-vrij beschrijven; woorden zijn door de wijze waarop wij ze in onze hersenen opslaan en verwerken aan de natuurlijke beperkingen van het taalvermogen gebonden. Woordbetekenissen maken woorden theoriegeladen.

- Bij de waarneming van de werkelijkheid streven onderzoekers ernaar dat het deel van de werkelijkheid dat wordt waargenomen 'klein' is en voor geen dubbelzinnigheid vatbaar. Als waarnemingen hieraan niet beantwoorden is er een probleem. Waarnemingen-in-de-tijd, waarnemingen van een verandering, waarnemingen van een object dat niet in een oogopslag waarneembaar is, zijn problematisch. De verschillen tussen de waarnemingen van twee of meer van dit soort objecten, lopen langs meer dan één dimensie. Verschillen tussen de waargenomen zaken kunnen niet op één schaal worden vergeleken. Zulke waarnemingen kunnen daarom niet worden gekwantificeerd.

- Er kan een probleem zijn als het object van onderzoek 'uniek' is. Onderzoekers zijn er eerder op uit regelmatigheden in de natuur op te sporen, dat wil zeggen uitspraken te doen over regelmatig terugkerende, en dus niet-unieke, objecten, gebeurtenissen, standen van zaken etc. We kunnen unieke verschijnselen alleen uniek karakteriseren als 
we ze zien als een unieke optelsom van algemeen voorkomende kenmerken. Generaliserende uitspraken over kenmerken zijn mogelijk, maar niet over 'unieke' onderzoeksobjecten.

- Ons verstand heeft moeite met het vaststellen en beoordelen van tegenstrijdigheden in grote hoeveelheden (algemene en singuliere) beweringen. Als samenhang, het ontbreken van inconsistenties, de maat van succes is voor verstehend inzicht, dan is deze begrenzing aan het menselijk verstand een beperking op de productie van wetenschappelijke kennis. Denkbaar is dat computers daar op den duur beter in zullen zijn dan het menselijk verstand. Maar voor een niet geformaliseerde theorie lijkt dat tijdstip nog ver weg.

- Iets dergelijks geldt voor het vaststellen van de 'empirische inhoud' van een bewering. De waarheid van een bewering is in beginsel afhankelijk van de waarheid van alle deductief daaruit af te leiden beweringen. Een boom van deducties is onbeperkt in de diepte uitbreidbaar. Voor Popper is dit een beslissend argument voor de opvatting dat de waarheid onbereikbaar is; dat al ons weten 'waarschijnlijkheidsweten' is.

begrensde rationaliteit
Deze elementen maken dat het vertrouwen op de rede als het instrument om kennis te produceren niet mag worden overdreven. De menselijke rede maakt ons niet almachtig. We moeten onze rationaliteit begrensd noemen.

Een begrensde rationaliteit neemt genoegen met voorlopige oplossingen. Volgens Apostel en Marly (1993) lijkt de wetenschappelijke manier van waarheidszoeken daarom op die van een rechter, meer dan onderzoekers doorgaans willen toegeven. Het waarheidszoeken in de rechtspraktijk wordt in hoge mate bepaald door de noodzaak een uitspraak te doen; dat wil zeggen een bewering, die niet in de strenge logische zin kracht van waarheid heeft, maar in de praktijk, in de samenleving wel als zodanig wordt geaccepteerd. Er moet in de rechtspraktijk een waarheid zijn, die althans voorlopig moet worden aanvaard. Daarmee krijgt het waarheidszoeken een doel.

Zo ook in de praktijk van het wetenschappelijk onderzoek. Dat onderzoek verloopt doelgerichter, meer met een voorlopige uitkomst in het achterhoofd dan doorgaans wordt toegegeven.

Vanuit dit perspectief zullen we ingaan op de praktijk van de expertise die in de geesteswetenschappen is opgebouwd. We zullen die expertise proberen te beschrijven in zijn maatschappelijke vorm, dat wil zeggen dat we zullen beschrijven hoe die expertise in de samenleving zichtbaar is en welk gebruik ervan wordt gemaakt. We beginnen met een paragraaf 


\section{Postmodernisme}

Postmodernisme is een term met een veelheid aan inhouden.

\section{In de filosofie}

Het postmodernisme in de filosofie is een stroming die zich keert tegen het vooruitgangsgeloof dat sinds de Verlichting van de achttiende eeuw de westerse wereld heeft beheerst. De term zelf is al oud, maar in de filosofie wordt er - voor het eerst in Frankrijk - van gesproken sinds de jaren zestig. Het is een vorm voor de frustratie over de nederlaag van het marxisme, over de opdringerigheid van de massacultuur en de bedreiging van een voortschrijdende technologie. Het postmodernisme heeft vooral een pragmatische, opportunistische (en sceptische) instelling tegenover de cultuur en de politiek. Het is in postmodern werk soms moeilijk om maatschappijkritiek en algemeen gevoel van zinloosheid van het bestaan van elkaar te onderscheiden. Het postmodernisme stelt zich te weer tegen alles wat met 'groei' of 'vooruitgang' te maken heeft. Het bundelt als zodanig ook allerlei denkbeelden die afbreuk doen aan de positie van de wetenschappen. Het postmoderne onbehagen in de cultuur is in de jaren zestig ontstaan in Amerika, en heeft later een nadere filosofische 'verwoording' gekregen van Franse filosofen, onder wie Foucault en Derrida.

\section{In de literatuur}

Als benaming voor een literaire stroming raakte de term postmodernisme in de jaren zeventig van de twintigste eeuw in zwang. Maar welke literaire werken de oudste postmoderne zijn, is omstreden. Joyce, Nabokov en Beckett worden soms al postmodern genoemd. Thomas Pynchon geldt als de meest postmoderne van alle.

Postmodernisten twijfelen aan de mogelijkheid of wenselijkheid literatuur voor een afbeelding van de werkelijkheid te houden. Literatuur verwijst niet naar de buiten-literaire wereld, maar naar zichzelf. Een literair werk weerspiegelt ander literair werk.

Ook heeft de persoonlijkheid of de biografie van de auteur een ondergeschikte positie.

\section{In de beeldende kunsten en de architectuur}

In de beeldende kunsten betekent het postmodernisme het gebruik van een veelheid aan stijlelementen door elkaar. Er is een herwaardering van kitsch- en popelementen. In de architectuur ligt de nadruk speciaal op het uiterlijk, niet op het functionele van het bouwwerk. Het postmodernisme wordt gezien als de uitdrukking van verzet tegen het modernisme en functionalisme.

Bron: Hans Bertens, The idea of the postmodern. A history 
waarin wat gegevens worden gepresenteerd die een beeld beogen te schetsen van de maatschappelijke positie van de letteren te midden van de andere wetenschappen.

8.1

twee culturen van Snow

bèta’s onder de alfa’s

\section{De geesteswetenschappen en andere wetenschappen}

De Engelse schrijver en fysicus C.P. Snow vestigde in 1958 in een beroemd geworden rede de aandacht op de grote cultuurverschillen tussen alfa's en bèta's. De rede had als titel The two cultures. Het bestaan van deze verschillen is wel uitgelegd als een aanwijzing dat de natuurwetenschappen en de cultuurwetenschappen onvergelijkbare grootheden zijn en dat er niet van een eenheid van kennis en kennisverwerving kan worden gesproken. Het denken van Dilthey, die zoals wij zagen een autonomie voor de alfavakken verdedigde, heeft in de verbreiding van dit idee een belangrijke rol gespeeld.

Van een principieel verschil tussen natuur- en cultuurwetenschappen als rationele activiteit kan naar onze mening echter niet worden gesproken. We hebben al laten zien dat het op een verouderd beeld van de menselijke natuur berust. Een belangrijk argument voor het afwijzen van Diltheys claim is ook het ontbreken van een scherpe scheidingslijn tussen de alfa-achtigen en de bèta-achtigen in de verzameling van de tientallen, zo niet honderden vakgebieden die in de wetenschap worden onderscheiden. Casimir, de oud-directeur van het natuurkundig laboratorium van Philips zei het op een congres over de twee culturen zo:

Het beoefenen van een tak van wetenschap brengt een bepaalde werkmethode en soms zelfs een bepaalde levenswijze met zich mee. Maar is er wat dat betreft een duidelijk verschil tussen alfa en bèta? Onzin. Het verschil tussen de archeoloog en de paleontoloog is zeker niet groter dat dan tussen de astronoom en de ichtyoloog. (Mijnhardt en Theunissen 1988: 61)

De eenvoudige scheidingslijn is er niet, als je kijkt naar de wetenschappelijke methode, en evenmin als je kijkt naar de mate waarin de met die methode verworven kennis betrouwbaar wordt geacht. Sprekend lijkt mij in dit verband ook het argument dat er geen aanwijzingen zijn dat bèta's de kennis die hun historisch geïnteresseerde collega's over de geschiedenis van de natuurwetenschappen produceren, bij voorbaat als irrationeel en onbetrouwbaar afwijzen.

Wellicht ten overvloede: Erkelens (1998) heeft recent vastgesteld dat er een aanzienlijke groep onderzoekers in de letteren werkzaam is, die wetenschappelijke attitudes van de bèta's hebben. Bèta-achtige attitudes 
worden aangetroffen bij de alfa's die nee zeggen op de vraag of hun onderzoek betrekking heeft op de zin van het menselijk bestaan. Volgens Erkelens gaat het hier met name om de taalkundigen.

En inderdaad: een paar keer hebben we in het bovenstaande kunnen vaststellen dat taalkundigen in het gebruik van de onderzoeksmethoden, in soorten data, in theorievorming zich van andere alfa's onderscheiden. Maar ook in Erkelens onderzoek blijken de verschillen en overeenkomsten niet zo scherp dat van twee culturen kan worden gesproken.

In het onderstaande vindt men een paar cijfers die een beeld beogen te geven van de positie van de geesteswetenschappen ten opzichte van de andere vakgebieden. Ze zijn gebaseerd op Langendorf (1990) en Van de Roer (1995).

Het aandeel van de geesteswetenschappen in alle wetenschappelijk onderzoek waar ook ter wereld uitgevoerd, ligt tussen de 5 en de $10 \%$. Voor Nederland was dat in 1992 9.3\%. Taal- en letterkunde samen vullen globaal de helft van dit volume. De kunstvakken en geschiedenis ieder een kwart.

Het aandeel van het aantal studenten dat een opleiding in een geesteswetenschappelijk vak volgt, ligt tussen de 15 en de $20 \%$. Dit aantal is in Nederland nu ongeveer 20.000.

In 1993 waren er in Nederland ongeveer tweeduizend fulltime onderzoeksbanen in de geesteswetenschappen door de overheid gefinancierd. Dat aantal zal tegenwoordig niet veel anders zijn.

$\begin{array}{lrr}\text { vakgebied } & \text { absoluut } & \text { in \% } \\ \text { landbouw } & & \\ \text { natuur } & 2074 & 5 \% \\ \text { techniek } & 6197 & 14 \% \\ \text { gezondheid } & 5376 & 12 \% \\ \text { economie } & 12661 & 28 \% \\ \text { recht } & 2071 & 5 \% \\ \text { gedrag \& maatschappij } & 4224 & 9 \% \\ \text { taal \& cultuur } & 7196 & 16 \% \\ \text { diversen } & 4887 & 11 \% \\ \text { totaal } & 122 & - \\ & 44808 & 100 \%\end{array}$

Tabel 5 Aantallen wetenschappelijke publicaties van Nederlandse onderzoekers in 1992 per wetenschapsgebied (in absolute getallen en procenten). De geesteswetenschappen worden in Nederlandse overheidspublicaties aangeduid als de sector 'taal en cultuur'. Boekbesprekingen en publicaties bestemd voor een algemeen publiek zijn in dit overzicht niet opgenomen. 
'werkplaats'

Volgens de informatie van het Institute of Scientific Information werden er in 1993 op het gebied van de geesteswetenschappen over de hele wereld ongeveer 100.000 artikelen gepubliceerd. 30.000 daarvan zijn te beschouwen als wetenschappelijke bijdragen; de rest wordt voornamelijk gevormd door boekbesprekingen. Ter vergelijking: op het gebied van de natuurwetenschappen verschenen in 1991 rond 400.000 nieuwe artikelen. Het aantal boekbesprekingen is hier gering. De sociale wetenschappen produceerden in 1994 ongeveer 63.000 wetenschappelijke artikelen en daarnaast ongeveer 40.000 boekbesprekingen. Het aandeel van de verschillende wetenschapsgebieden in de totale Nederlandse wetenschappelijke productie, vindt men in bijgaande tabel 5 .

Samenvattend kunnen we zeggen dat de letteren ongeveer een tiende deel vormen van alle wetenschappelijke bedrijvigheid.

Veruit het grootste deel van het onderzoek in de geesteswetenschappen, ongeveer 90\% wordt verricht aan de universiteiten. Daarnaast bestaan er een hele reeks gespecialiseerde onderzoeksinstituten. We noemen er een paar:

- het vroegere RIOD (Rijksinstituut voor oorlogsdocumentatie), thans NIOD (Nederlands Instituut voor oorlogsdocumentatie) voor de geschiedenis van de Tweede Wereldoorlog;

- het BBT(Bureau Basisvoorziening Tekstedities), dat edities van belangrijk Nederlands letterkundig werk verzorgt;

- het Pieter Meertens Instituut, dat vooral historisch-antropologisch onderzoek doet op het gebied van dialecten, volksmuziek, volksverhalen etc.

- het Instituut voor Nederlandse Lexicografie, dat materiaal verzamelt en beheert dat ten grondslag ligt aan Nederlandse woordenboeken.

Ook sommige musea, de diensten voor de Monumentenzorg en de archiefdiensten van rijk, provincies en gemeenten hebben een onderzoekstaak.

\section{2}

de expertise van de letteren betreft drie gebieden: de taal, het verleden en het unieke en waardevolle

\section{De waarde van geesteswetenschappelijke kennis}

De expertise van de geesteswetenschappen ligt op drie gebieden: de taal, het verleden en het unieke en waardevolle. Op ieder van de genoemde gebieden produceren de geesteswetenschappen kennis, en op ieder van die gebieden worden ze op de beschikbare kennis aangesproken. We zullen die aanspraken achtereenvolgens onder de loupe nemen.

Daarbij zullen we een onderscheid aanbrengen tussen de technische rol en de culturele rol van een wetenschap. Over de technische rolvan een 
technische en

culturele rollen van een wetenschap

\subsection{1}

de expertise op het gebied van de taal: de technische rol wetenschap spreken we als de wetenschap antwoord geeft op een vraag die aan de beoefenaren van dat vak wordt voorgelegd. In deze technische rol weerspiegelt een wetenschap het duidelijkst hoe ze door de buitenwereld wordt waargenomen, hoe haar een maatschappelijke functie wordt toegedacht.

We zien een wetenschap in de culturele rol, als de beoefenaren van een vak vrij en ongebonden door directe vragen of problemen nieuwe kennis produceren. In deze culturele rol weerspiegelt een wetenschapsgebied vooral haar interne dynamiek en haar groeimogelijkheden.

\section{De waarde van taalkundige kennis}

Grote delen van het moderne taalkundig onderzoek zijn nog zuiver wetenschappelijk. Hier willen we speciaal aandacht besteden aan die vormen van taalkundig onderzoek die toepasbaar zijn. Er bestaan, voorzover bekend, geen degelijke analyses van het gebruik dat het publiek maakt van taalkundige kennis. Het volgende is gebaseerd op enige impressies.

Van de taalkunde wordt in de eerste plaats verwacht dat ze de taal als lenig en efficiënt instrument voor verkeer van de burgers beschikbaar houdt. Het volgende citaat uit een rede van de historicus Kossmann over de rol en de waarde van de geesteswetenschappen, beschrijft het belang hiervan in geïdealiseerde termen. Het taalaspect wordt erin aangeduid met de term 'vocabulair'.

[...] de beschaving dient het de leden van een samenleving mogelijk te maken elkaar te verstaan. Zij moet een toegankelijk vocabulair en een stelsel van als niet-willekeurig beschouwde waarden scheppen of bewaren. Maar dat is natuurlijk niet voldoende. De totalitaire maatschappijen uit het verleden en het heden waar onze maatschappij zich tegenover pleegt te plaatsen, slagen er immers ook heel goed in zo'n vocabulair en zo'n waardenstelsel te ontwikkelen. Het verschil is dat de totalitaire maatschappij aan haar vocabulair en waardenstelsel het absolutisme van een vrijwel volmaakte zekerheid verleent terwijl vocabulair en waardenstelsel in het democratische bewustzijn middelen vormen, noodzakelijke middelen om individuele standpunten aan andere mensen uit te leggen. Die middelen zijn noodzakelijk, niet omdat zij als volstrekt juist worden ervaren, maar omdat degeen die weigert hen te gebruiken geen begrip zal vinden. Degene die de sociale uitkeringen of de ontwikkelingshulp wil beperken en de defensie wil versterken krijgt voor zijn standpunt nergens gehoor als hij aankomt met het argument dat het bevolkingsprobleem kan worden 
opgelost door de armen te laten verhongeren en bloedige oorlogen te doen uitbreken. (Kossmann 1985)

grammatica en spelling

dubbelhartige houding van taalkundigen ten opzichte van 'goed' en 'fout' taalgebruik

effectief en nieteffectief taalgebruik: communicatiekunde
Hoewel de taal zeker niet te gronde gaat als taalkundigen er zich niet mee zouden bemoeien, is enige zorg voor de taal toch gewenst. Deze 'taalzorg' dient vooral de standaardisering en normering van de taal. Spellingsordening, beschrijving van een woordenschat en regels voor woordvorming en zinsbouw zijn daar traditioneel de duidelijkste uitdrukking van. Hier zien we de taalkunde het meest uitgesproken in een technische rol. De totstandkoming van een Algemene Nederlandse Spraakkunst in 1984 is het antwoord op een vraag vanuit de wereld van neerlandici die het Nederlands in het buitenland of aan buitenlanders in Nederland doceren. De behoefte aan een spellingsregeling is in Nederland door de politiek uitgesproken en zelfs in een taalverdrag tussen Nederland en de Vlaamse gemeenschap in België neergelegd. Het is zeker niet zo dat zonder de overheid de spelling een rommeltje zou worden. Het maatschappelijk gedrag in dezen zou ook heel goed - en waarschijnlijk zelfs beterdoor een samenwerking van lexicografen-taalkundigen en uitgevers in de private sector kunnen worden gestuurd. Maar het is evident dat een ordening ervan maatschappelijk gewenst is. Terwijl gebruikers ervan de spellingsregels en grammatica vooral zien als aanwijzingen over hoe het eigenlijk hoort, als bronnen voor normatieve oordelen over taal, worden ze in de eerste plaats vervaardigd als beschrijvingen van het feitelijke gebruik.

Taalkundigen hebben een dubbelhartige houding ten opzichte van hun eigen rol in het handhaven van wat wel 'verbale hygiëne' is genoemd. (Cameron 1995) Aan de ene kant werken taalkundigen wel mee aan standaardiseringswerk: spellingsregelingen, uitspraakwoordenboeken etc, zodat de taalgebruiker het vastgelegde gebruik kan navolgen, maar aan de andere kant weigeren ze meestal iemands taalgebruik in voorkomende gevallen 'goed' of 'fout' te noemen. Ze erkennen wel dat je de taal effectief of niet effectief kunt gebruiken, maar niet dat je de taal kunt sturen of veranderen. Ze nemen er nota van dat het gebruik van ' $h u n$ ' als onderwerp, zoals in 'hun hebben een nieuwe auto' voorkomt en misschien wel veld wint, maar menen geen taak te hebben op deze ontwikkeling in positieve of negatieve zin invloed uit te oefenen. We ontmoeten hier een verschijnsel dat we ook voor de andere letterenvakken zullen tegenkomen: een duidelijke afstand tussen vraag en aanbod, tussen de intentie waarmee het aanbod aan kennis wordt vervaardigd en de vraag naar die kennis bij het publiek.

De studie van effectiviteit van taalgebruik resulteert in een taalkundige expertise waar de laatste jaren een groeiende vraag naar is. Er is sprake van een groeiende belangstelling voor de mogelijkheden om het taalgebruik 
beheer van dialecten als cultureel erfgoed

taalkunde en automatisering

taalkunde en het taalonderwijs in communicatie te sturen. Het meest duidelijk neemt dat vorm aan in de expertise op het gebied van voorlichtende teksten door overheid en ondernemers. Zo wil de overheid 'leesbare' belastingbiljetten, subsidieregelingen etc. en 'leesbare' instructies om die te gebruiken. Ondernemers erkennen hoe langer hoe meer het belang van 'leesbare' gebruiksaanwijzingen voor elektronica, software, geneesmiddelen etc. Waar vroeger juristen of technici dit soort teksten maakten, wordt nu de waarde van een specialistische communicatiekundige expertise steeds beter erkend. Eenzelfde ontwikkeling is zichtbaar in de steeds groeiende behoefte aan communicatieadviezen op het vlak van het mondelinge taalgebruik. Steeds vaker is de talige interactie tussen professionals (artsen, juristen) en hun cliënten, en tussen politici en hun kiezers voorwerp van specialistische trainingen. Het onderzoek op het gebied van de communicatiekunde is erop gericht een onderbouwing te leveren van de intuitieve normatieve oordelen die het publiek in de eerste plaats verwacht.

Naast de zorg voor de standaardtaal is er ook zorg voor de dialecten. De houding ten opzichte van het dialectgebruik is in de twintigste eeuw radicaal veranderd. Hoewel het actieve gebruik van de dialecten in $\mathrm{Ne}$ derland in de twintigste eeuw snel is achteruitgegaan, is de 'museale' belangstelling ervoor de laatste decennia gegroeid. De dialecten worden nu benaderd als cultureel erfgoed dat als zodanig zorg vereist, zoals monumenten of gebruiksvoorwerpen van vroeger. In het regionaal bewustzijn speelt de taal van de streek voor veel mensen nog steeds een grote rol. Het bestaan van dialectrubrieken in de regionale pers en van toneelverenigingen die toneelstukken in dialect op de planken brengen, getuigt hiervan. Ook hier leveren taalkundigen dialectologische expertise: ze werken aan dialectwoordenboeken en aan de standaardisering van dialectspellingen.

Een heel andere ontwikkeling van de afgelopen decennia is de automatisering. Er is hier een duidelijk herkenbare sector waar taalkundige expertise gevraagd wordt. De taalkunde speelt een rol bij de verwerking van taal door computers in sectoren als de automatische spraakherkenning (spraak is een soort 'vingerafdruk': iedere stem heeft een eigen karakteristiek patroon), de spraaksynthese, het automatisch vertalen en tekst-naar-spraak-omzettingen. Deze gebieden laten hoe langer hoe duidelijker een betrokkenheid van het bedrijfsleven bij het taalkundig onderzoek zien. De toepassingen worden ook hoe langer hoe meer commerciëel 'interessant'.

Ten slotte kan nog gewezen worden op de rol die de taalkundige speelt in de productie van kennis op het gebied van het taalonderwijs. Nieuwe lesmethodes zijn het resultaat. Ook wordt er veel onderzoek verricht naar het effect van het verschil tussen thuistaal en schooltaal, tussen de 
... en de culturele rol

de sociale dimensie van taalkundig onderzoek

de psychische dimensie van taalkundig onderzoek taal waarin een kind wordt opgevoed en de taal die het op school geacht wordt te gebruiken. De laatste decennia is de aandacht op dit terrein verschoven van de problematiek van dialectsprekers naar die van de etnische minderheden. Hoewel op dit gebied wereldwijd veel onderzoek wordt gedaan, en er in het taalonderwijs ook zeer veel veranderingen zijn opgetreden, is het totale effect van het onderzoek op veranderende lesmethodes en leraarsgedrag moeilijk zichtbaar te maken.

Op deze gebieden zien we de taalkunde in zijn technische rol. Kijken we vervolgens naar de culturele rol. De wetenschappelijke fundering van de taalkundige expertise kent twee dimensies, de sociale en de psychische.

In de sociale dimensie onderzoekt men aard, spreiding en dynamiek van variatie van taalgebruik binnen een taalgemeenschap of tussen verschillende taalgemeenschappen. Het dialectonderzoek hoort hier thuis, en het onderzoek naar taaleigenaardigheden die verschillende groepen in de samenleving van elkaar onderscheidt: jongerentaal, studententaal, bargoens etc. Dit onderzoek mag zich in een grote publieke belangstelling verheugen.

De aandacht voor de taal als psychisch fenomeen, de psychische dimensie, heeft sinds de jaren vijftig een bijzondere wetenschappelijke diepgang gekregen door het werk van de Amerikaanse linguïst Noam Chomsky. We hebben al eerder gezien dat het hierbij gaat om vragen omtrent de taal als vermogen van de menselijke geest, en vragen aangaande het taalverwervingsvermogen bij zeer jonge kinderen. Theorieën over taal en taalgedrag zijn kenbronnen geworden van de werking van de menselijke geest, belangrijk voor de psychologie en de andere cognitieve wetenschappen. (vgl. Pinker 1994, 1997)

De taalkunde in deze wetenschappelijke gedaante is - wellicht meer dan een van de andere geesteswetenschappen - esoterisch geworden, dat wil zeggen voor een buitenstaander niet zonder meer toegankelijk. Ook het onderzoek naar verschillende vormen van taalstoornissen (afasie, stotteren, dyslexie etc.) hoort in deze psychische dimensie. Voorzover bekend is de expertise op deze terreinen nog niet van dien aard dat taalkundigen zich al tot therapeuten ontwikkelen.

De waarde van historische kennis

de expertise van de geschiedbeoefening

Kijken we vervolgens naar de geschiedbeoefening. We maken weer een verschil tussen de technische en de culturele rol van de geschiedbeoefenaren.

de technische rol
De historicus in een technische rol heeft in onze cultuur verschillende gedaanten. We onderscheiden 
- de historicus als archivaris;

- de historicus als geschiedschrijver-op-bestelling;

- de historicus op de rechterstoel.

de historicus in de technische rol 1: de archivaris

editeren

de technische rol 2: geschiedschrijving op bestelling

de technische rol 3: de geschiedenis op de rechterstoel
In de rol van archivaris is de historicus beheerder van materiële objecten uit het verleden, meestal van geschreven stukken. Daarbij denken we in de eerste plaats aan degenen die werken in door de overheid in stand gehouden instituten die het beheer van archieven tot doel hebben. De overheid heeft zulke archieven voor het bewaren van door haarzelf geproduceerde documenten, maar helpt ook bijzondere collecties of collecties over bijzondere sectoren of periodes van de cultuur in stand houden. Zo is er voor de sociale geschiedenis van Nederland (en ver daarbuiten) het IISG, het Internationaal Instituut voor Sociale Geschiedenis, en voor de geschiedenis van de Tweede Wereldoorlog, het al genoemde NIOD. Zulke instituten hebben niet alleen tot taak archieven te beheren, maar ze moeten ze ook verwerven en aanvullen, toegankelijk maken, ordenen en beschrijven.Ze moeten zorgen dat er met de archieven gewerkt kan worden.

Onder deze beheerstaak kunnen we ook het editeren rangschikken: het uitgeven van gedeelten van die archieven, die belangrijk genoeg zijn om gemakkelijker, ruimer en houdbaarder beschikbaar te zijn dan in de originele papieren vorm. De indrukwekkende reeks van de Rijks Geschiedkundige Publicatiën, waarin edities van allerlei documentenreeksen werden ondergebracht, vormt een mooi voorbeeld.

Geschiedschrijving kan op bestelling worden geleverd. Als de Staat der Nederlanden in de paspoorten voor haar onderdanen een beschrijving van de geschiedenis van de Nederlanden wil, dan bestelt ze die. Zo worden ook wensen van bedrijven of instellingen bevredigd. Het Prins Bernhard-fonds kan zijn ontstaan en ontwikkeling op bestelling laten onderzoeken en beschrijven, of De Hoogovens, of De Nederlandse Bank etc. Historici leveren de benodigde expertise. De opdrachtgevers behartigen hier tegenwoordig op een chique manier hun public relations mee. Voor historici is het soms extra interessant, omdat bedrijfs- of instellingsarchieven open gaan die anders gesloten zouden zijn gebleven. In onze cultuur zijn het vooral jubilea die historisch onderzoek uitlokken. Historische boek- of tijdschriftpublicaties betreffende een jubilerende instelling of organisatie accentueren de continuïteit waar men deel aan heeft. Er wordt hier op een moderne manier een oude traditie voortgezet. Machtsaanspraken en glorie werden oudtijds al vaak door middel van historisch onderzoek ondersteund. Dit maakte historici soms tot partijgangers van de machtigen der aarde.

Soms krijgen historici de opdracht om belangrijke maatschappelijke controverses te beslechten. Een goed voorbeeld is de recente opdracht die het NIOD van de Nederlandse regering heeft gekregen, om uit te zoeken 
maatschappelijke waarde van dit onderzoek

en de wetenschappelijke waarde?

ethisch relativisme wat er nu precies is voorgevallen rond de val van de Bosnisch-Servische enclave Srebrenica in juli 1995, en welke verantwoordelijkheid de Nederlanders hadden die betrokken waren bij de beslissingen om de enclave op te geven. De opdracht vloeide voort uit de aanhoudende maatschappelijke en politieke onvrede omtrent de rapportages die de minister daarover aan de Tweede Kamer verschafte, en de onmacht of onwil van de minister om meer of andere informatie te verstrekken. Een juridisch onderzoek was niet op zijn plaats, een parlementair onderzoek inopportuun, en een internationaal onderzoek onhaalbaar. $\mathrm{Nu}$ is het dus een historisch onderzoek geworden.

Zien we hier de historicus als rechter? Er zijn duidelijke overeenkomsten. Ook al kan de historicus geen mensen onder ede horen, qua grondigheid, onpartijdigheid en betrouwbaarheid zal het niet voor een gerechtelijk onderzoek behoeven onder te doen. Het oordeel van de historicus heeft geen directe juridische consequenties. Er zullen ook geen onmiddellijke politieke consequenties aan vast zitten. Voor de personen die worden gehoord is er geen directe strafbedreiging. Dat geeft aan de uitkomsten wellicht iets vrijblijvends, maar ook een aspect van belangeloosheid, alsof er afstand is geschapen tot de actualiteit. De functie van het onderzoek lijkt in de eerste plaats te zijn de maatschappij uit de verlegenheid te helpen, en het gevoel van collectieve machteloosheid en schuld een vorm te geven. Hier is zeker van toepassing wat Huizinga over de geschiedbeoefening in het algemeen heeft gezegd: in dit historisch onderzoek geeft de cultuur zich rekenschap van een stukje van haar verleden. Aan de historicus wordt dus soms toevertrouwd een soort eindoordeel te vellen over figuren of groepen die op een bijzondere manier hun stempel op de samenleving hebben gedrukt. 'De tijd zal oordelen' wordt in onze cultuur begrepen als 'de geschiedenis zal oordelen'.

Wetenschapstheoretisch is van belang dat het historisch onderzoek met zulk quasi-juridisch karakter aan weinig wetenschapstheoretische twijfels onderhevig zal zijn, tenzij scherpe politieke tegenstellingen er de achtergrond van vormen. In het algemeen is er net zomin als bij een juridisch onderzoek reden tot twijfel of het onderzoek wel 'waarheidsgetrouw' zal zijn. Wetenschapstheoretische voorbehouden ten aanzien van de waarheidsaanspraken zal de maatschappij niet maken.

We voegen hier nog enkele woorden toe over het zgn. 'ethisch relativis$m e$. We hebben in hoofdstuk 5 gezien dat geesteswetenschappers hun object van onderzoek soms vergelijken met een norm. Dit verschaft inzicht als het gaat om een waardebepaling van dat object, bijvoorbeeld een ethische waarde. We hebben er op die plaats ook al op gewezen dat de keuze van zo'n norm op heftig verzet kan stuiten. Een historicus als rechter heeft bij wijze van spreken zelf de keuze van het wetboek dat hij gebruiken zal. Hij/zij zou enerzijds het ethische waardestelsel van de eigen tijd 
geschiedbeoefening in de culturele rol

historici zijn het niet eens over de rol van de geschiedbeoefening in de samenleving als maat voor het oordeel kunnen nemen, of een waardestelsel dat geacht wordt een universele geldigheid te hebben, zoals dat van de Universele Verklaring van de Rechten van de Mens. Anderzijds staat als mogelijkheid open dat hij/zij het oordeel afmeet aan het waardestelsel dat gold in de tijd of in de cultuur waarover hij schrijft. Handelingen zullen immers vanuit de context moeten worden begrepen. Daar zit een element van verontschuldigen in. 'Alles begrijpen is alles vergeven.' Dit laatste standpunt wordt wel ethisch relativisme genoemd. Waar het kentheoretisch relativisme zegt dat er geen universele waarheden bestaan, waarheden die door ieder mens op rationele gronden moeten worden aanvaard, zegt het ethisch relativisme dat er geen universele regels voor het onderscheid tussen 'goed' en 'kwaad' bestaan. Wat (ethisch) goed is en wat kwaad, wordt bepaald door de omstandigheden. Het dilemma lijkt niet geheel onoplosbaar.

Wie aan het idee van menselijke verantwoordelijkheid en aanspreekbaarheid gehecht is kan [...] de apologetische consequenties van het 'alles begrijpen' alleen vermijden door de onderzochte handelingen niet alleen op de normen van de actor te betrekken, maar ook op universele normen met betrekking tot menselijke verantwoordelijkheid. (Lorenz 1987: 265)

De historicus heeft de vrijheid beide te doen: hij kan zowel het ethische waardestelsel hanteren dat in de door hem beschreven periode en cultuur gold, als het hedendaagse of het veronderstelde universele waardenstelsel.

Terwijl er over de technische rol van de geschiedbeoefening eigenlijk nauwelijks verschil van mening is, lijkt er over de culturele rol van de geschiedbeoefening grote verwarring te bestaan. De bedoelingen van de historici zijn zelf niet onderling consistent, en lijken ver verwijderd van het feitelijk gebruik dat het publiek van historische kennis maakt. We zullen betogen dat dit essentieel is voor de wijze waarop historische kennis in onze cultuur wordt gebruikt.

Historici hebben uiteenlopende denkbeelden over de maatschappelijke waarde van hun vak. In een krantenstuk vonden we de volgende opinies. De een vindt dat een historicus zich bewust moet mengen in het actuele debat over politieke en maatschappelijke kwesties. Een ander is van mening dat een historicus moet laten zien met welke problemen de samenleving worstelt: hij moet de politici helpen rampen te analyseren en te bedwingen. Weer een ander wil dat juist niet. Die ziet een historicus als een antropoloog in een vreemd land, nieuwsgierig naar wat wezenlijk anders is in het verleden om daarover spannende verhalen te vertellen. Men vindt ook historici die zichzelf de rol van psychotherapeut toedich- 
historici lijken hun maatschappelijke rol te dramatiseren

de lijst van Kocka ten, iemand die mensen helpt hun identiteit te vinden. En dan zijn er ook nog boutades als die van Oakeshot die de geschiedenis een geliefde vindt 'waarvan men niet verwacht dat die iets zinvols zegt'.

Welke bijdrage de historicus nu precies levert op basis van het uitgangspunt dat een zo groot mogelijke rationaliteit in het werk wordt betracht, is hieruit niet op te maken. Men kan zich niet aan de indruk onttrekken dat de historicus zichzelf graag een dramatische rol aanmeet: staatsman of politiek adviseur, mensenredder of rampenbestrijder, ontdekkingsreiziger of geestelijk leidsman.

De Duitse historicus Jürgen Kocka (1977) heeft een lijst opgesteld, waarin hij acht functies opsomt van het historisch onderzoek. Eén ervan is 'divertissement'. De andere zeven zijn de volgende.

- de geschiedenis toont de wortels van hedendaagse verschijnselen: waar komt racisme vandaan? waar hebben we de parlementaire democratie aan ontleend?

- de geschiedenis is een reservoir van kennis, voorstellingen, ervaringen, motivaties en normen. Op dat reservoir kan ieder naar eigen goeddunken een beroep doen. Een bekend voorbeeld is de appeasementpolitiek tegenover dictators. De Britse premier Chamberlain meende in 1938 door in München concessies te doen aan Hitler de vrede te kunnen verzekeren. Hitler werd in zijn veroveringsplannen slechts gestimuleerd door die concessies, die hij interpreteerde als tekenen van zwakte van zijn tegenstanders. Zo'n voorbeeld heeft nog steeds kracht. Het werd bijvoorbeeld weer gebruikt in de discussie over de vraag hoe het Westen op moest treden tegen de Iraakse dictator Saddam Hoessein, of de Verenigde Naties tegen de Bosnische Serviërs.

- de geschiedenis geeft door vergelijking meer inzicht in het heden. Over het verleden is soms meer bekend, omdat documenten na verloop van tijd openbaar worden. Ook hebben we tot het verleden meer afstand dan tot het heden, zodat we afstandelijker analyses kunnen geven. De corrumperende werking van macht kun je bijvoorbeeld net zo goed onderzoeken aan de hand van voorbeelden uit de Romeinse oudheid of het vijftiende-eeuwse Florence als met hedendaagse gebeurtenissen.

- de geschiedenis kan gezag legitimeren (en protest ertegen). Dat in Nederland het staatshoofd behoort tot het Huis van Oranje kan met een beroep op de geschiedenis (en met een beroep op de grondwet) worden gelegitimeerd.

- met behulp van de geschiedenis kan de veranderbaarheid van het heden worden gedemonstreerd. Nog maar een paar jaar geleden leek het feit dat het Oostblok communistisch was een op graniet gefundeerd feit. Zien dat de werkelijkheid historisch gegroeid is en niet in alle 
zegt dit iets over de motieven voor de historische vakbeoefening?

de feitelijke productie van historische kennis facetten onvermijdelijk is, kan bijdragen aan een realistische houding tegenover die werkelijkheid.

- de geschiedenis is een leerschool in concreet denken. De geschiedenis houdt zich veelal bezig met individuele gebeurtenissen en concrete gevallen. Dat valt vooral op als je het vak vergelijkt met bijvoorbeeld de sociale wetenschappen, waar de analyse vaak meer gericht is op abstracte categorieën.

- de geschiedenis vormt identiteit. Historische voorbeelden dragen bij aan de betekenisgeving van wat het is om man of vrouw te zijn, Frans of Pools, marinier of wetenschapper, student, christen, allochtoon of autochtoon.

De lijst zegt mijns inziens weinig over de bedoelingen waarmee historische kennis wordt geproduceerd. Een historicus die een studie presenteert en daarmee 'de veranderbaarheid van het heden' wil aantonen, of 'de legitimatie van een of ander gezag', dat hij 'de lezer het heden beter wil leren kennen', 'wil opvoeden tot concreet denken' of 'de identiteit van de lezer wil helpen vormen', zo'n historicus wordt gewantrouwd. De historicus zal de dienstbaarheid aan deze functies ook snel ervaren als een aanslag op de rationaliteit, en zulke dienstbaarheid dus willen vermijden.

Men kan uit de uitspraken van historici over de functie van hun vak niet veel afleiden over de manier waarop dat vak wordt beoefend. De uitspraken zijn veronderstellingen of wenselijkheden over de wijze waarop de samenleving de geschiedbeoefening zal appreciëren.

De cijfers in bijgaande Tabel 6 laten zien waar de aandacht van Nederlandse historici naar uitging in de jaren tachtig. Ze zijn ontleend aan overzichten van de publicaties over de geschiedenis van Nederland, die verschenen zijn in de jaren 1989, 1990 en 1991. In de linkerkolom staat de periode waarop de aantallen publicaties in de middelste kolom betrekking hebben.

Het is opvallend hoeveel boeken en artikelen aspecten van de periode van de Tweede Wereldoorlog aan de orde stellen. Omdat niet alle periodes even lang zijn, is berekend hoe groot de 'publicatiedichtheid' is, dat wil zeggen het aantal publicaties gedeeld door de lengte van de periode waar die publicaties betrekking op hebben. De resultaten vindt men in de rechterkolom van de tabel. De eenzijdigheid van de aandacht van de geschiedbeoefening van Nederland voor de Tweede Wereldoorlog komt nu wel heel scherp aan het licht. Uit de gegevens spreekt ook een zekere verwaarlozing van de negentiende-eeuwse geschiedenis, in ieder geval van die van de tweede helft van die eeuw. Er zijn aanwijzingen dat een groot deel van het onderzoek betreffende de recente geschiedenis door beoefenaren van de sociale wetenschappen wordt gedaan. (Pollmann 1998b) 


$\begin{array}{ll}\text { tijdvak antal publicaties } & \begin{array}{l}\text { aantal publicaties per jaar van de } \\ \text { genoemde periode }\end{array}\end{array}$

$\begin{array}{lrr}4^{\mathrm{e}} \text { eeuw-1492 } & 270 & 0.2 \\ 1492-1555 & 30 & 0.4 \\ 1555-1648 & 121 & 1.3 \\ 1648-1795 & 167 & 1.1 \\ 1795-1813 & 35 & 1.9 \\ 1813-1848 & 53 & 1.5 \\ 1848-1914 & 58 & 0.8 \\ 1914-1940 & 73 & 2.8 \\ 1940-1945 & 761 & 152.2 \\ 1945- \pm 1990 & 186 & 4.1\end{array}$

Tabel 6 Aantallen publicaties uit 1989-1991 over een onderwerp uit de Nederlandse geschiedenis per historische periode; en het gemiddelde aantal publicaties per jaar van die periode (gebaseerd op Bos en Schillings 1992, 1993, 1995)

de waarde van historische kennis vanuit het consumentenstandpunt

noemt de lijst van

Kocka motieven van de consument?
Tot zover over de maatschappelijke positie van de geschiedbeoefening gezien vanuit het gezichtspunt van de 'producent'. Wenden we ons vervolgens tot de 'consument'. Welke behoefte heeft de consument aan historische kennis? Wanneer komt een niet-historicus in aanraking met historische kennis? En wat verwacht men daarvan?

Ook hierover zijn - kenmerkend genoeg - weinig gegevens beschikbaar. Eén onderzoek heeft door middel van een enquête onder de politiek-bestuurlijke elite aan het licht gebracht dat het gebruik van historische informatie op Nederlandse ministeries 'beperkt' is.

Het gebruik van historische informatie in het beleidsproces lijkt het grootst te zijn bij Buitenlandse Zaken, Defensie en Waterstaat. Bij departementen als Economische Zaken en Financiën neemt historische informatie vooral de vorm aan van evaluaties van het gevoerde beleid, vooral ook onder het financiële gezichtspunt. (Hoogerwerf 1989: 68)

In het volgende vindt men over het gebruik van historische kennis enkele impressies aangevuld met wat kwantitatieve gegevens.

Zegt de lijst van Kocka iets over de motieven om historische kennis te consumeren? Laten we beginnen met op te merken dat geen kennis een zo indringende culturele rol speelt als de kennis omtrent het eigen verleden. Mensen, families, groepen net zozeer als organisaties, naties en samenlevingen ontlenen hun identiteit aan hun verleden. Vraag aan iemand wie 
de behoefte aan

historische kennis is toevallig hij/zij is, en als je meer te horen krijgt dan een naam, hoor je een stukje persoonlijke geschiedenis. Geen geschiedenis zo interessant als van de eigen familie, van vrienden of bekenden, van de eigen stad of streek, de eigen club, het eigen bedrijf. Maar door de historicus geproduceerde kennis speelt hierin meestal een ondergeschikte rol.

Maar ook daarbuiten is geschiedenis. Voor wie om zich heen kijkt, stelt de wereld allerlei vragen die een historisch antwoord behoeven. Speciaal op momenten of in situaties die nieuw zijn (op reis, in een periode van crisis) ontstaat de behoefte aan een oriëntatie die noodzakelijk ook kennis omtrent het verleden omvat. Men kan hierin bevestigd zien wat ook uit de lijst van Kocka blijkt - dat de behoefte aan historische kennis niet uit een belangstelling voor het verleden om het verleden voortkomt, maar vooral door het toeval van de persoonlijke omstandigheden of de actualiteit wordt bepaald. Een paar - persoonlijk getinte - voorbeelden.

- Men kan als toerist in Assisi zijn en de behoefte voelen om geïnformeerd te worden over de aard van het religieuze bestaan dat hier kennelijk haar centrum vindt. Een reisgids biedt een eerste oriëntatie. Maar er blijkt veel meer prachtigs over het franciscanisme geschreven te zijn. Wie suggereerde het boek van Nolthenius (1989)? Hoe ver men zich door zijn belangstelling wil laten meeslepen, is moeilijk te voorspellen. De ervaring leert dat die meestal bevredigd is voordat de vraag naar de 'levensidentiteit' van de toerist aan de orde komt. Voor de historisch geïnteresseerde kan die zelfs beter buiten beschouwing blijven.

- Men kan als onderzoeker op een dag de behoefte hebben iets meer te weten over het ontstaan van ons systeem van getallen, de notatiewijze, de uitvinding van de decimale komma, van de nul etc. Daar blijken voortreffelijke boeken over te bestaan (Menninger 1969; Ifrah 1994), die een evidente cumulatie van kennis laten zien, goed gedocumenteerd zijn en een heel rationeel inzicht geven in de wordingsgeschiedenis van het decimale systeem.

- Men kan op een dag door een collega getrakteerd worden op de kennismaking met een historische studie die een overzicht geeft van de ontwikkeling van de gewone - niet gezwollen of retorische - maar zakelijke tekst. In het negentiende-eeuwse Amerika leert men de waarde kennen van een zakelijke omgangstaal, die ontdaan is van retorische overdaad en versieringen (Cmiel 1990). Ook deze geschiedenis blijkt goed gedocumenteerd. Men had zich wellicht nooit gerealiseerd dat deze ontwikkeling die toch in soorten teksten zo manifest is, zou kunnen worden beschreven. Men had zich nooit gerealiseerd dat men iets niet wist; en ineens blijkt ook deze kennis te bestaan. 
historisch onderzoek bevredigt rationele informatiebehoefte

behoefte aan historische kennis wordt bepaald door het heden van de gebruiker de spreiding van de belangstelling voor het verleden
Het blijft mysterieus waarom nu juist deze historische onderwerpen de agenda van de geest bepaalden. Er is geen systematiek, geen behoefte om 'het' verleden als geheel te leren kennen.

De voorbeelden illustreren dat de historische informatie voor de gebruiker ervan in de eerste plaats tegemoet komt aan een informatiebehoefte, waarmee deze zich oriënteert in de wereld. Iemand die niks heeft met Franciscus van Assisi, of met getallen en rekenen, of met retorische middelen, aan zo iemand gaat de genoemde historische informatie voorbij. Maar wat de lezer er precies mee doet, behoeft niet door de historicus te worden aangegeven. Dat kan ook moeilijk door de historicus worden voorzien. De manier waarop de lezer de historische kennis zal integreren in hetgeen hij of zij verder weet van de wereld, bepaalt de lezer het liefst zelf.

De behoefte bij het publiek aan historische kennis komt voort uit een behoefte de eigen wereld en de actualiteit ervan te begrijpen. Vandaar dat de belangstelling voor het verleden in het algemeen afneemt naarmate we verder in het verleden teruggaan. Het volgende kan dit illustreren.

Een indicatie van de frequentie waarmee het publiek in aanraking komt met het verleden is te vinden in de frequentie waarmee in een krant over (delen van) het verleden wordt geschreven. De grafiek van figuur 5 op de volgende bladzijde is gebaseerd op het gebruik van jaartallen in het Nederlandse NRC/Handelsblad en de Frankfurter Allgemeine Zeitung. Van ieder jaartal is geteld hoe vaak het in de krant voorkwam. De aanwezigheid van een jaartal in een krant is een verwijzing naar het verleden. Hun aantallen brengen de aandacht voor het verleden enigermate in beeld. Zoals verwacht neemt het aantal keren dat aan het verleden wordt gerefereerd af, naarmate we verder in het verleden teruggaan. Maar jaren of periodes met een bijzondere culturele betekenis doorbreken deze algemene tendens. In figuur 5 is de periode 1990-1930 in beeld gebracht. Verreweg het grootste deel van de aandacht voor het verleden heeft betrekking op het hele recente verleden, maar er is een duidelijke piek bij de jaren 1944 en 1945. En kleinere piekjes bij 1968, 1938 en 1933. Ook de ronde jaren vertonen pieken.

In figuur 6 zijn de gegevens over periode 1900-1400 in beeld gebracht. Daar ziet men dat de hoeveelheid aandacht die de Nederlandse en de Duitse krant besteden aan de verschillende periodes uit het verleden, niet dezelfde is. De Frankfurter besteedt verhoudingsgewijs veel aandacht aan de tweede helft van de achttiende eeuw, terwijl de $N R C$ van de Nederlandse lezers juist veel aandacht vraagt voor de Gouden zeventiende eeuw.

De grafieken zijn te interpreteren als een afspiegeling van de spreiding van de historische informatie die de krant zijn lezers verschaft en daarom indirect als een afspiegeling van de belangstelling van de krantenlezers. 


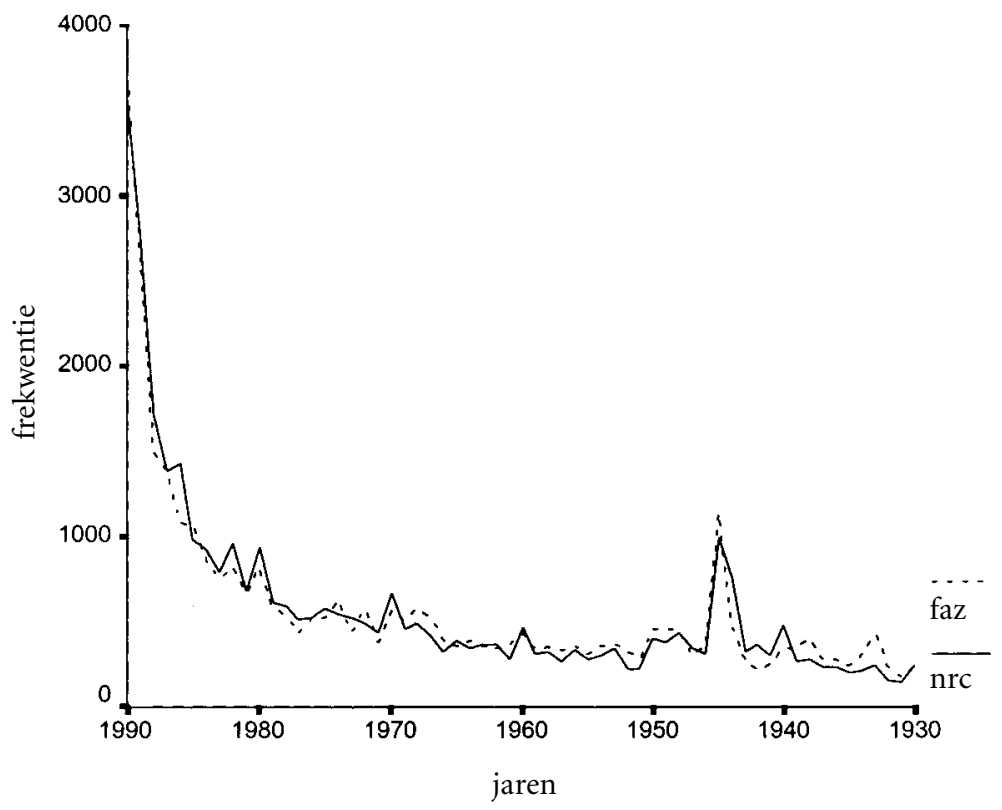

Figuur 5 aantallen jaartallen tussen 1990 en 1930 genoemd in de jaargang 1994 van de Frankfurter Allgemeine Zeitung en de jaargang 1994 en de eerste vier maanden van 1995 in NRC/Handelsblad

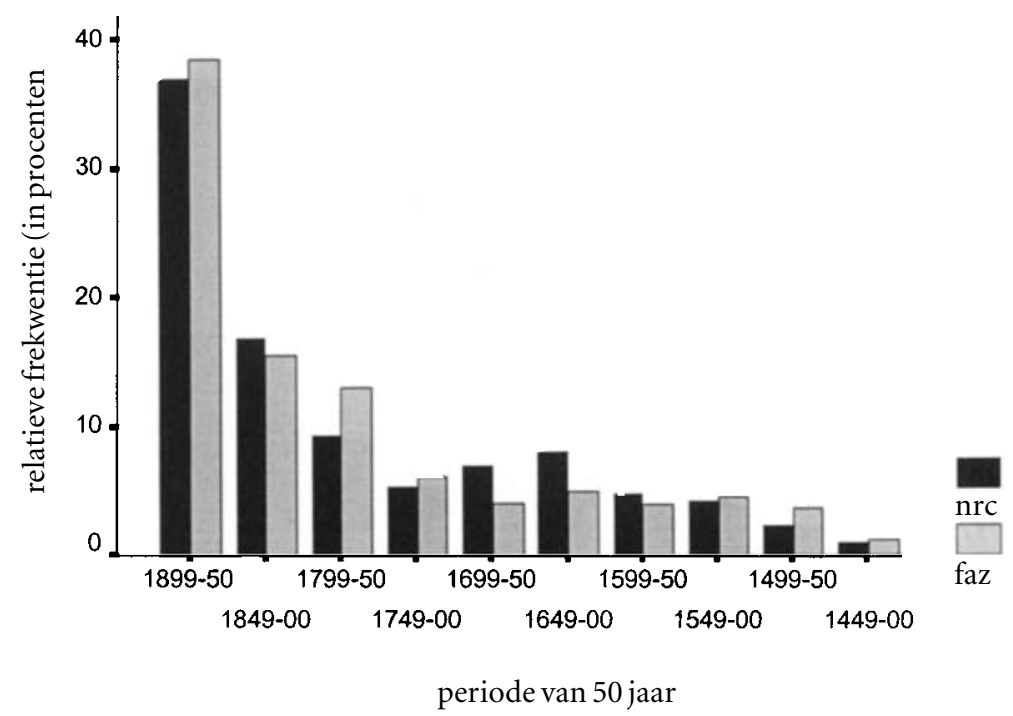

Figuur 6 relatieve frequenties van jaartallen tussen 1900 en 1400 (in groepen van vijftig jaren) in de jaargang 1994 van de Frankfurter Allgemeine Zeitung en de jaargang 1994 en de eerste vier maanden van 1995 in NRC/Handelsblad (in procenten) 
karakteristiek van de culturele rol van de geschiedbeoefening

\subsection{3}

de expertise op het gebied van het unieke en waardevolle: de kunstvakken in hun technische rol...

expertise aangaande de kunstwerken

expertise aangaande het kunstleven
Samenvattend. Het lijdt geen twijfel: de cultuur vertrouwt aan de geschiedbeoefening de zorg toe voor het levend houden van een reeks aspecten van het verleden. Maar de geschiedbeoefenaren beantwoorden niet aan die behoefte op basis van marktonderzoek. Ze volgen doorgaans hun eigen belangstelling; over de belangstelling van het publiek verkeren ze in het ongewisse. Op de markt van de historische kennis gaapt een kloof tussen vraag en aanbod. Historici produceren voor het merendeel in vrijheid en bekommeren zich weinig om wat de lezer (bijvoorbeeld op grond van de veronderstelde functies van historische kennis, zoals we die hiervoor leerden kennen) nodig heeft. En omgekeerd: de lezers maken een tamelijk toevallig en meestal onsystematisch gebruik van wat aan kennis voorradig is. Deze onafhankelijkheid bij producenten en consumenten lijkt essentieel voor het functioneren van de geschiedbeoefening in onze cultuur.

\section{De waarde van de wetenschappelijke kennis over de kunsten}

De technische rol van de kunstwetenschappen komt het duidelijkst tot uitdrukking in de expertise die zij aanwenden in kunstinstellingen. Voorzover de overheid of organisaties het zich tot een taak rekenen de kunstwerken te beheren, leveren de kunstwetenschappers expertise aangaande de beste manier om de kunstwerken te bewaren en voor het publiek beschikbaar te stellen. Wat mensen bewonderen, daar willen ze 'alles'van weten.

De expertise geldt hier in de eerste plaats individuele kunstwerken: hun ontstaan, hun makers, hun geschiedenis, hun interpretatie, de waardering die ze hebben ondervonden, de wijze waarop ze bij het publiek het beste tot hun recht komen etc. De kunsthistorici realiseren deze rol als conservatoren in musea en inrichters van tentoonstellingen. Bij de literatuurwetenschap en de musicologie komt deze beheerstaak tot uiting in het verzorgen van edities van literaire werken en composities. Het lezen en interpreteren van handschriften vergt een expertise omtrent stijl, functie en ontstaansgeschiedenis van de werken. Dit nauwkeurig lezen, interpreteren, van commentaar voorzien en beschikbaar stellen voor hedendaagse kunstliefhebbers wordt filologie genoemd. Hier vinden we de moderne geesteswetenschappers het duidelijkst als erfgenamen van de humanistische geleerdheid van late Middeleeuwen en Renaissance waar we in het inleidende hoofdstuk mee kennis maakten.

Speciaal voor de materiële objecten geldt dat kunstwetenschappers ook in hun rol van connaisseurs betrokken worden bij taxaties, bij echtheidscertificering, bij aankoop, bij het verzamelen, bij restauratie etc.

Maar daarnaast leveren de kunstwetenschappers ook allerlei kennis over het culturele systeem: de relatie van de kunstwerken tot andere cul- 
...en culturele rol

beheer van objecten, kennisbeheer en kennisproductie gaan hand in hand

de kunstkritiek tuurverschijnselen, de kunsttraditie, het kunstbeleid, de wijze waarop kunst in de samenleving functioneert. Kennis omtrent cultuurparticipatie, of omtrent de factoren die dit in de weg staan, maakt hier deel van uit. Verder spelen de beoefenaren van de kunstdisciplines een rol bij de advisering van de overheden in kunstaangelegenheden, en bij het organiseren van kunstmanifestaties, in jury's etc.

De culturele rol van de kunstwetenschappers is in hoge mate vergelijkbaar met die van de geschiedbeoefening: ook hun is als het ware door de cultuur toevertrouwd de zorg voor het levend houden van een reeks aspecten van het verleden. Ze begeleiden het kunstleven. Die culturele rol van de kunstwetenschappen leidt er toe dat een geïnteresseerde leek ook over buitengewoon veel aspecten van literatuur, beeldende kunst, theater, muziek etc. in boekhandels en bibliotheken informatie kan vinden. Ook hier geldt, net als bij de geschiedbeoefening, dat die informatie vaak ontstaat zonder dat er een welomschreven behoefte van potentiële lezers zichtbaar was. Wel wordt een nieuwe presentatie van kunstwerken, een nieuwe teksteditie, een bijzondere programmering in concertzaal of theater soms de aanleiding voor hernieuwd begeleidend onderzoek. Zoals jubilea gemakkelijk historisch onderzoek kunnen uitlokken, zo kunnen tentoonstellingen, uitvoeringen en tekstedities begeleidende gezaghebbende publicaties uitlokken. De Mondriaantentoonstelling van voorjaar 1995 bracht een golf van nieuw onderzoek met zich mee. Hier ontmoeten de technische en culturele rol elkaar. Maar meestal wordt de kennis op het gebied van de kunstdisciplines zonder zo'n direct doel voortgebracht.

De gegeven voorbeelden zullen illustreren dat beheer van de objecten, kennisbeheer en kennisproductie in de maatschappelijke functie van de kunstwetenschappen hand in hand gaan. Dit verklaart op zijn beurt weer de verwevenheid van de kunstwetenschappen en de geschiedbeoefening.

Kenmerkend voor de kunstwetenschappen is nog een ander aspect van hun culturele rol. Dat is de kunstkritiek. We bedoelen daarmee niet in de eerste plaats de praktijk van het recenseren. Met kunstkritiek bedoelen we het genre waarin een wetenschapper optreedt als kunstbeschouwer, als beschrijver van lees-, kijk- en luisterervaringen. Deze critici 'openen' het kunstwerk door het als kunstwerk te beschrijven. Nederlandse voorbeelden van kunstcritici in deze zin zijn Kees Fens en Gerrit Komrij voor de literatuur, Elmer Schönberger voor de muziek, Eddy de Jongh voor de beeldende kunst en Willem Jan Otten voor toneel en film. Hun werk is een combinatie van eruditie, inlevingsvermogen, goede smaak en een grote vaardigheid in lezen, kijken en luisteren. Hun stukken hebben ook pas hun werking als ze zelf kunststukjes zijn geworden. Kunstkritiek wordt ook zelf soms als een kunstvorm beschouwd.

Kunstkritiek heeft kenmerken gemeen met geschiedschrijving. Beide richten zich op een groter publiek dan de vakgenoten. Beide vermijden 
problematische

kanten van de kunstkritiek

de kunstwetenschapper en de kunstenaar kunstkritiek als vorm van kunstwetenschap esoterische vaktaal en hebben de toegankelijkheid van de kennis hoog in het vaandel staan. Beide hebben het karakter van 'toegepaste wetenschap', in die zin dat ze beschikbare kennis en theoretische noties benutten, eerder dan die te helpen ontwikkelen.

Aan dit aspect van het maatschappelijk functioneren van de kunstwetenschappen kunnen drie problematische facetten worden onderscheiden:

- de verhouding van de kritiek ten opzichte van de kunstenaar;

- de kunstkritiek als vorm van (toegepaste) kunstwetenschap;

- de relatie van de kunstbeschouwer ten opzichte van het publiek.

Die aspecten zullen we achtereenvolgens beschrijven.

De kunstwetenschappers zijn experts op het gebied van de kunsten, maar niet zoals kunstenaars dat zijn. Behalve dat ze de objecten waar ze over spreken niet zelf hebben geproduceerd, is hun kennis over kunstobjecten ook van een andere orde. De kunstwetenschappers zullen proberen te systematiseren, en op de wijze van de wetenschap open voor kritiek en controleerbaar hun observaties beschrijven, terwijl de kunstenaars vanuit de eigen creatieve ervaring intuïtief en meestal partieel over eigen en andermans kunst praten. De criticus zal een grotere afstand als perspectief kiezen en een grotere, vaak cultuurhistorische context beschrijven. Soms zijn er sporen van animositeit waarneembaar. Dan heten de critici, in de karikatuur van Frye,

intellectuals who have a taste for art but lack both the power to produce it and the money to patronize it, and thus form a class of cultural middlemen, distributing culture to society at a profit to themselves while exploiting the artist and increasing the strain on his public.

(1957:3)

Zulke kritiek, misschien van toepassing op de knoeiers en middelmatigen, ketst af op het werk van de goeden.

Kunstkritiek wordt lang niet door iedereen als een een vorm van (kunst-)wetenschap gezien. We hebben al vastgesteld dat voor sommige onderzoekers het object van onderzoek niet het individuele kunstwerk is, maar het functioneren ervan in het culturele systeem. Een individueel kunstwerk in beschouwing nemen leidt tot allerlei subjectieve oordelen, gebaseerd op de eigen normen van de criticus, zo menen bijvoorbeeld Fokkema en Ibsch. (1992: 27) Een criticus praat over waarden. De kunstwetenschapper daarentegen beschouwt het kunstwerk (slechts) als een onderdeel van het onderzoeksobject. Het 'maakt er deel van uit voorzover het forum (schrijvers, critici, lezers) hem creëert, respectievelijk op hem reageert, kortom voorzover [het kunstwerk] een betekenis en waarde 
scheppende functie heeft'. Kunstonderzoek is (lees: moet zijn) receptieonderzoek met een 'historisch-documentaire tak, en een empirisch-experimentele [tak, waarin] reacties van levende lezers en lezersgroepen met behulp van sociaal-psychologische methoden worden onderzocht'. (ibidem 32) Verdedigers van de kunstkritiek stellen daar tegenover dat de wetenschap in de hier bedoelde zin het zicht beneemt op de kunstwerken en niet tot interessante probleemstellingen komt. Dat het onderzoek geen betrekking heeft op de vraag: 'wat zijn nu eigenlijk de eigenschappen van die kunstobjecten, die maken dat mensen er genoegen aan beleven?' (Van het Reve 1991: 102). Er is hier sprake van een aanzienlijk verschil van inzicht. Speciaal in de literatuurwetenschap zijn in dit debat veel scherpe woorden gewisseld.

Wat kan hier vanuit de wetenschapstheorie over gezegd worden? Ten eerste moet het opvallende feit gesignaleerd worden dat beide partijen, in ieder geval in de gedaante waarin ze hier in het strijdperk zijn gevoerd, aan anderen voorschrijven welke objecten ze moeten onderzoeken om aanspraak te maken op wetenschappelijkheid. Dat is een zinloze bezigheid. Het enige dat telt ten aanzien van de wetenschappelijkheid van een onderzoeksobject, is de vraag of er een probleem is en of dat probleem van dien aard is dat het rationeel is om aan een oplossing ervan te werken. Mijns inziens kan men aan de kunstwetenschappers niet ontzeggen dat zij laten zien welke (interpretatieve) problemen er om een oplossing vragen. De onleesbaarheid van de wetenschappelijke publicaties deelt de literatuurwetenschap met veel andere wetenschappen, en is op zichzelf geen reden om de onderzoeksresultaten te misprijzen.

Ten tweede is niet goed in te zien waarom kunstkritiek geen rationeel te rechtvaardigen analyses oplevert. Noch het unieke, noch het intentionele karakter van kunstobjecten, noch het vermoeden dat de wetenschap geen laatste of definitieve woorden over kunst kan spreken, maakt de objecten onbenaderbaar voor de wetenschap. We hebben ook gezien dat een verstehende benadering die in de kunstkritiek gangbaar is, een rationele basis niet kan worden ontzegd. Het is niet in te zien waarom een methode die aan de 'historisch-documentaire tak' wordt toegestaan, voor het interpreteren van een literair werk onbetrouwbaar moet worden geacht.

kunstkritiek en waardeoordelen
Maar, zo zou men kunnen tegenwerpen, wat moeten we denken van de waardeoordelen in de kunstkritiek? Zijn die niet in strijd met het in de wetenschappen alom onderschreven waardevrijheidspostulaat, dat zegt dat de wetenschap waardevrij hoort te zijn en dat de wetenschapper zich dient te onthouden van waardeoordelen? Er zijn allerlei redenen waarom deze eis niet noodzakelijk rationele analyses van kunst in de weg behoeft te staan. We noemen er een paar. Ten eerste opereert een kunstcriticus niet in een waardevrije wereld. Ofwel hij of zij ontleent het object van 
natuurlijk vermogen

tot waardeonder-

scheid maakt alle waarneming waardegeladen

kunstkritiek en het publiek onderzoek aan een canon, een (imaginaire) lijst van kunstwerken die er toe doen, of niet. In het eerste geval sleept hij/zij de waardegeladenheid van het object mee in het onderzoek. Niemand die Gorter onderzoekt, kan er onderuit dat zijn Verzen tot de belangrijkste gedichten in de $\mathrm{Ne}$ derlandse taal gerekend worden. Maar als het object niet tot de canon behoort, zoals Gorters socialistische gedichten, ontleent de onderzoeker de redenen om er zich mee bezig te houden toch aan esthetische ideeën die in de contemporaine cultuur bestaan. Hij kan er niet omheen zijn belangstelling aan de canon te meten. De selectie van het onderzoeksobject is onvermijdelijk niet waardevrij.

Hetzelfde geldt voor de effecten van het onderzoek. Ook die zijn niet waardevrij. Bedoeld of onbedoeld zal alle kunstkritisch onderzoek stof blazen van en de schijnwerper richten op cultuurbezit, dat zoals alle menselijke artefacten aan vergetelheid en vergankelijkheid is blootgesteld. Dat dit onvermijdelijk is, hangt onder andere samen met het natuurlijk vermogen tot waardeonderscheid, dat wij mensen hebben. Niet dat we niet door onze omgeving beïnvloed worden in de manier waarop we dit waardeonderscheid hanteren. We leren in onze opvoeding in globale zin wat onze waardehorizon is, dat wil zeggen welke dingen we mooi, nastrevenswaardig, aantrekkelijk en waardevol moeten vinden en welke niet. Maar de gevoeligheid voor het onderscheid kunnen we niet onderdrukken. We kunnen eenvoudig geen dingen in de werkelijkheid waarnemen zonder de waarde ervan te wegen. Het waardevrijheidspostulaat is aan de beperkingen van onze menselijke natuur onderhevig. Net zoals we moeten accepteren dat onze waarneming theoriegeladen is, zo moeten we accepteren dat onze waarneming waardegeladen is. Zelfs als literatuurwetenschappers zich aan een onderzoek zetten van 'triviaal-literatuur', zoals damesromans, doktersromans, kasteelromans etc. zullen daarin sommige werken wel en andere niet worden betrokken. Alle wetenschappen hebben hun canon. Dat neemt niet weg dat expliciete waardeoordelen het functioneren van de kunstkritiek in de weg kunnen staan. Dat heeft te maken met het derde aspect van kunstkritiek dat wij hier onder de aandacht willen brengen, en dat is de functie ervan ten opzichte van het publiek.

We zeiden hierboven dat de kunstkritiek de functie heeft het kunstwerk te 'openen', tot spreken te brengen, uiteraard voorzover het zichzelf niet compleet en zonder raadsels (maar wat is compleet en zonder raadsels?) te kennen geeft. Dat klinkt aanmatigend. Spreekt kunst niet voor zichzelf? In beginsel mogelijk wel, maar veel mensen voelen de behoefte aan een zekere begeleiding en toelichting van de criticus die beter lezen, kijken en luisteren kan. Het bestaan van de cultureel supplementen in de landelijke dagbladen is een belangrijke aanwijzing dat een dergelijke behoefte bestaat. 
De kunstcriticus zal vaak beginnen te problematiseren wat ogenschijnlijk probleemloos is. Niet zelden blijkt een ogenschijnlijk detail een sleutel tot een algemener, 'groter' raadsel. Zolang de criticus het zicht op het kunstwerk niet belemmert en het kunstwerk niet overschaduwd wordt door het commentaar, zal de kunstkritiek aan de behoefte van het publiek kunnen voldoen.

Net als bij de geschiedenis rekent de lezer bij de kunstbeschouwing af en toe op een waardeoordeel, nu niet van een ethische orde, maar van een esthetische. Vergelijking, meten aan een norm, het inpassen van een kunstwerk in een canon van kunstwerken behoort tot de taak van de kritiek. De onderzoeker/criticus vormt of volgt geen jurisprudentie, maar in de terminologie van Rokus de Groot (1993) een 'artisprudentie', een zich ontwikkelende kennis omtrent de aspecten van het 'schone', die er in de oordeelsvorming toe doen. Expliciete waardeoordelen, die voor de kijker, luisteraar of lezer niet voortkomen uit de kijk-, luister- of leeservaring zelf kunnen het tot spreken brengen van het kunstwerk in de weg staan.

De analyse van de grondslagen van deze oordeelsvorming en van de kwaliteiten die in het oordeel kunnen worden betrokken, is het terrein van de esthetica. De doorsnee-geesteswetenschapper toont een zekere huiver om zich met deze expliciete oordeelsvorming bezig te houden, onzeker als hij is over de rationaliteit, de beredeneerbaarheid van deze oordelen.

de expertise van de geesteswetenschappen is deel van het culturele systeem

wetenschappen produceren niet alleen kennis, maar beheren ook kennis
Tot slot nog dit. We hebben in het inleidende hoofdstuk in navolging van Goudsblom de geesteswetenschappen gekarakteriseerd als een verzameling vakgebieden die de samenbindende kracht vindt in een enigszins elitaire cultuuropvatting. Aan hun eenheid ligt een speciale waardegeladen visie op het menselijk bestaan en de cultuur ten grondslag. In deze visie wordt speciaal aan de objecten van onderzoek een bijzondere culturele waarde toegekend. Dit wil nog niet zeggen dat in de cultuur ook een bijzondere culturele waarde wordt toegekend aan de door de geesteswetenschappen geproduceerde kennis over die objecten van onderzoek. In de maatschappelijke discussie worden deze dingen vaak door elkaar gehaald. Dan wordt de culturele waarde van de taalkunde gelijk gesteld aan de culturele waarde van de taal; of de culturele waarde van de kennis over de werken van Rembrandt gelijk gesteld aan de werken van Rembrandt etc. Hoe ontstaat deze verwarring?

In het inleidende hoofdstuk hebben we ook gezegd dat de wetenschappen naast kennisproductie, ook kennisbeheer tot hun taak rekenen. Bij dit laatste moet men denken aan het voor verschillende publieksgroepen in de samenleving beschikbaar stellen, en het reactiveren en toegankelijk maken van kennis. In dit opzicht gaan de objecten van 
onderzoek en de beschikbare kennis over die objecten vaak hand in hand. Zo kan de minister van Onderwijs en Wetenschappen dan ook zeggen over het wetenschappelijk en maatschappelijk belang van de kunstgeschiedenis:

De discipline kunstgeschiedenis verzamelt kennis over en analyseert en interpreteert beeldende kunst, architectuur en kunstnijverheid. Hiermee houdt zij de traditie levend op het terrein van de (beeldende) kunst, waaraan Nederland van oudsher zulk een essentiële bijdrage heeft geleverd. Dit definieert tevens het intrinsiek wetenschappelijke maar ook het cultureel-maatschappelijke belang van de discipline. (HOOP 1993: 122)

de kennis over een De kennis over een verschijnsel dat in de cultuur levend gehouden moet cultuurverschijnsel worden, wordt als het ware een deel van het culturele verschijnsel zelf. De wordt deel ervan kennis gaat onderdeel van de culturele traditie uitmaken waartoe ook de kunstobjecten zelf behoren. Misschien nog sprekender dan voor de kunstgeschiedenis, geldt dit voor de geschiedbeoefening. Behalve in de materiële objecten (archiefbescheiden, monumenten etc.) heeft het verleden immers geen andere bestaanswijze dan in de vorm van de kennis die over het verleden bewaard en op grond daarvan geproduceerd is. 


\section{Bibliografie}

Adviesraad voor het Wetenschaps- en Technologiebeleid (1997) Wisselwerking tussen 'zachte' en 'harde' kennis. Benutting van $\alpha$ en $\gamma$-kennis in van oudsher $\beta$ dominante sectoren. Den Haag

Allen, Bryce, Jian Qin en F.W. Lancaster, (1994) 'Persuasive Communities: A longitudinal Analysis of References in the Philosophical Transactions of the Royal Society, 1665-1990', in Social Studies of Science 24, pp. 279-310

Alpers, Svetlana (1983) The art of describing. Dutch art in the seventeenth century. The University of Chicago Press, Chicago

Alphen, Ernst van, en Maaike Meijer (eds.) (1991) De canon onder vuur: Nederlandse literatuur tegendraads gelezen. Van Gennep, Amsterdam

Andringa, Els (1991) 'Expert readers before 'before the law', in Ibsch, Schram, Steen (eds.) pp. 39-48

Ankersmit, F.R. (1981) Narrative logic. A semantic analysis of the historian's language. Dissertatie Groningen [z.p.]

Ankersmit, F.R. (1990) 'Over aard en toetsing van geschiedkundige interpretaties' in: G. Nuchelmans e.a. (1990) pp. 37-47

Apostel, Leo (1993) Waarde en zin van de cultuurwetenschappen in de twintigste eeuw. Met redactionele medewerking van Theo Venckeleer en Werner Verbeke. Pelckmans, Kok Agora, Vlaamse Vereniging voor Cultuurwetenschappen, Kapellen (B.), Kampen (NL.), Leuven (B.)

Apostel, Leo en Jenny Walry (1993) 'Een nawoord voor de toekomst', in L. Apostel (1993) pp.147-175

Ariosto, Ludovico (1532) Orlando Furioso. De Razende Roeland. (vert. Ike Cialona) Athenaeum Polak en Van Gennep, Amsterdam 1998.

Bank, Jan (1994) 'Muziek: een vergeten hoofdstuk in de Nederlandse cultuurgeschiedenis', in Paul van Reijen (ed.)(1994) pp. 21-30

Barnes, Annette (1988) On interpretation. A critical analysis. Basil Blackwell Oxford (UK), Cambridge (Mass.)

Bart, Peter van en Arie Sturm (1987) Zinsanalyse en de termen die daarbijgebruikt worden. Martinus Nijhoff, Leiden

Berkel, K. van (1985) In het voetspoor van Stevin. Geschiedenis van de natuurwetenschap in Nederland 1580-1940. Boom, Meppel/Amsterdam

Berkson, William (1995) 'Two commandments for the humanities', in I.C. Jarvie en N. Laor (eds.) Critical rationalism, the social sciences and the humanities. Essays for Joseph Agassi. Vol II. Kluwer Academic publishers, Dordrecht etc., pp. 221-233

Beukel, A.van den (1990) De dingen hebben hun geheim; gedachten over natuurkunde, mens en God. Ten Have, Baarn

Bingham, Barry (1966) 'A journalist looks at the humanities', in Monroe C. Beardsley, Northrop Frye, Frank Kermode, and Barry Bingham, The humanities and the understanding of reality. University of Kentucky Press, Lexington. pp. 75-84

Boer, Pim den (1990) 'Innovatie en geschiedwetenschap', in Fokkema en Ruiter (eds.) pp. 57-67 
Bommeljé, Bastiaan, (1995) 'Een dubbel post mortem. Karl Popper en de geschiedfilosofie', in Hollands Maandblad 36-1, pp.3-14

Bos, Th.S.H. en M.C.W. Schillings (1992) Repertorium van boeken en tijdschriftartikelen betreffende de geschiedenis van Nederland verschenen in 1989. Instituut voor Nederlandse Geschiedenis, Den Haag

Bos, Th.S.H. en M.C.W. Schillings (1993) Repertorium van boeken en tijdschriftartikelen betreffende de geschiedenis van Nederland verschenen in 1990. Instituut voor Nederlandse Geschiedenis, Den Haag

Bos, Th.S.H. en M.C.W. Schillings (1995) Repertorium van boeken en tijdschriftartikelen betreffende de geschiedenis van Nederland verschenen in 1991. Instituut voor Nederlandse Geschiedenis, Den Haag

Brakel, J.van, en J.T. van den Brink, (1988) Filosofie van de wetenschappen. Muiderberg, Coutinho

Budd, John M. (1989) 'Research in the two cultures: the nature of scholarship in Science and the humanities', in Collection Management 11-3/4 pp. 1-21

Buikema, Rosemarie en Anneke Smelik (1993) Vrouwenstudies in de cultuurwetenschappen. Coutinho, Muiderberg

Buuren, M.B. van (1988) Filosofie van de algemene literatuurwetenschap. Martinus Nijhoff, Leiden

Cameron, Deborah (1995) Verbal hygiene. Routledge, London

Cmiel, Kenneth (1990) Democratic eloquence. The fight over popular speech in nineteenth-century America. University of California Press, Berkeley-Los Angeles-Oxford

Commissie Toekomst van de Geesteswetenschappen (1995) Men weegt kaneel bij 't lood. Utrecht

Couch, Nena en Nancy Allen (1993) The humanities and the library. Chicago

Culler, Jonathan (1989) On deconstruction. Theory and criticism after structuralism. Routledge \& Kegan Paul, London

Currie G. en A. Musgrave (1985) Popper and the human sciences. Martinus Nijhoff publishers, Dordrecht Boston Lancaster

Darwin, Charles, De reis van de 'Beagle'. Dagboek van de onderzoekingen betreffende de natuurlijke geschiedenis en de geologie van de streken bezocht gedurende de reis van Hr. Ms. 'Beagle'. Arnhem Nijmegen: E. en M. Cohen, z.j. Deel VII uit Darwin's biologische meesterwerken voor Nederlanders bewerkt door H. Hartogh Heys van Zouteveen en T.C.Winkler.

Davids, Karel (1993) 'Technological change and the economic expansion of the Dutch republic, 1580-1680' in Karel Davids en Leo Noordegraaf (eds.) The Dutch economy in the golden age. Nine studies. Amsterdam. pp.79-104

Davidson, Donald (1984) Inquiries into truth and interpretation. Oxford, Clarendon Press

Derks, Peter L. (1994) 'Clockwork Shakespeare: The bard meets the repressive imagery dictionary' in Empirical Studies of the Arts 12 (2), pp.131-139

Derksen, A.A. (1993) 'The seven sins of pseudo-science', in Journal for general philosophy of science 24, pp. 17-42

Deursen, A. Th. van (1994) Een dorp in depolder. Graft in de zeventiende eeuw. Amsterdam, Bert Bakker

Dilthey, Wilhelm (1975) 'Die Auslegung oder Interpretation', in Th. Cramer en $\mathrm{H}$. Wenzel, Literaturwissenschaft und Literaturgeschichte. Wilhelm Fink Verlag München, pp. 70-74

Dilthey, Wilhelm (1983) Texte zur Kritik der historischen Vernunft. Herausgegeben und eingeleitet von Hans-Ulrich Lessing. Vandenhoeck \& Ruprecht Göttingen

Dunk, Herman von der (1974) Kleio heeft duizend ogen. Over historie en historici. Assen, Van Gorcum \& Comp. b.v. 
Dussen, W.J.van der (1988) Filosofie van de geschiedwetenschappen. Martinus Nijhoff, Leiden

Dijksterhuis, E.J. (1943) Simon Stevin. Martinus Nijhoff, 's-Gravenhage

Dijksterhuis, E.J. $\left(1977^{3}\right)$ De mechanisering van het wereldbeeld. Meulenhoff, Amsterdam

Erasmus (1972) Ausgewählte Schriften. Ausgabe in acht Bänden Lateinisch und Deutsch. Siebenter Band. Wissenschaftliche Buchgesellschaft, Darmstadt

Erkelens, Herbert van (1998) 'Kanttekeningen bij de twee culturen', in Tijdschrift voor Wetenschap, Technologie en Samenleving 2, 50-55

Floris Cohen, H. (1988) 'De wetenschapsrevolutie van de 17e eeuw en de eenheid van het wetenschappelijk denken', in Mijnhardt en Theunissen (eds.) (1988), pp. 3-14

Fogel, Robert W. en G.R. Elton, (1983) Which road to the past? Two views of histo$r y$. Yale University Press, New Haven en London

Fogel, Robert W. en Stanley L. Engerman (1974) Time on the cross. Boston (2 delen)

Fokkema, D. (1990) 'The study of literature', in Zürcher en Langendorff (eds.) pp. 227-256

Fokkema, D. en Frans Ruiter (eds.) (1990) Innovatie. Bijdragen tot het symposion 'Innovatie in wetenschap, kunsten bedrijfsleven'. John Benjamins b.v., Amsterdam 1990

Fokkema, Douwe en Elrud Ibsch (1992) Literatuurwetenschap en Cultuuroverdracht. Coutinho, Muiderberg

Foucault, Michel (1977) The order of things. An archaeology of the human sciences. Tavistock Publications, London

Foucault, Michel (1977) Discipline and Punish. The birth of the prison. Penguin books, London

Foucault, Michel (1988) De orde van het spreken. Inleiding en vertaling Thomas Widdershoven. Boom, Meppel/Amsterdam

Fraassen, Bas van (1980) The scientific image. Clarendon Press, Oxford.

Frijhoff, Willem (1988) 'Cultuur in het meervoud? Een alfa-vertoog over de opkomst van een betacultuur' in Mijnhardt en Theunissen (eds.) (1988), pp. 2439

Frye, Northrop (1957), Anatomy of criticism. Princeton

Garfield, E. (1987) 'A different sort of great-book list: the 50 twentieth-century works most cited in the Arts \& Humanities Citation Index, 1976-1983, in Current contents 9-16, pp.3-7; herdrukt in Arts \& Humanities Citation Index. First semi-annual, Volume 1. Institute for scientific information 1994, pp. 7-11

Geerts, G. en andere (1984) Algemene Nederlandse Spraakkunst. Groningen Wolters-Noordhoff/Leuven Wolters

Gelderblom, Arie Jan (1993) 'Ceci n'est pas une pipe. Kunstgeschiedenis en semiotiek', in Halbertsma en Zijlmans, pp. 271-310

Gerritsen, W.P. (1997) 'Het lastige leitje van Lopikerkapel', in Frank Willaert (ed.) Veelderhande liedekens. Studies over het Nederlandse lied tot 160o. Symposium Antwerpen 28 februari 1995. Peeters, Leuven

Goudsblom, Joop (1990) The humanities and the social sciences, in Zürcher en Langendorff (1990) pp. 23-41

Grafton, Anthony (1983-1993) Joseph Scaliger. A study in the history of classical scholarship. Clarendon Press, Oxford (twee delen)

Grafton, Anthony en Lisa Jardine (1986) From Humanism to the humanities. Education and the liberal arts in Fifteenth-and Sixteenth-Century Europe. Harvard University Press, Cambridge (Mass.)

Grafton, Anthony (1991) Defenders of the Text. The traditions of scholarship in an 
age of science, 1450-180o. Harvard University Press, Cambridge (Mass.), London

Grafton, Anthony (1996) 'The new science and the traditions of humanism', in Jill Kraye, The Cambridge companion to Renaissance humanism. Cambridge University Press, Cambridge, pp. 203-224

Grice, Paul (1989) Studies in the way of words. Harvard University Press, Cambridge (Mass.) London

Groot, Rokus de (1993) 'Kiezen en delen: op zoek naar kwaliteitsverschillen tussen muziekwerken', in Nierop, Maarten van, Renée van de Vall en Albert van der Schoot (eds.) (1993) pp. 125-138

Gutman, Robert (1970) Richard Wagner. Der Mensch, sein Werk, seine Zeit. München, Wilhelm Heyne Verlag

Haack, Susan (1995) Evidence and Inquiry. Towards Reconstruction of Epistemolo$g y$. Blackwell Oxford (UK), Cambridge (Mass.)

Halbertsma, Marlite en Kitty Zijlmans (1993) Gezichtspunten. Een inleiding in de methoden van de kunstgeschiedenis. SUN, Nijmegen

Harsema, Martine en Caroline Schröder (1998) 'De nieuwe literatuurgeschiedenis moet een mooi verhaal worden', in VakTaal 11-2, pp. 1-5

Hart, J. 't, R. Collier en A. Cohen (1990) A perceptual study of intonation. An experimental-phonetic approach to speech melody. Cambridge University Press, Cambridge etc.

Hempel, C.G. (1942) The function of general laws in history. Herdrukt als Aspects of scientific explanation. The free press, New York

Hertog, C.H. den $\left(1973^{3}\right)$ Nederlandse spraakkunst ingeleid en bewerkt door $\mathrm{H}$. Hulshof. Derde stuk. De leer van de woordsoorten. W. Versluys Uitgeversmaatschappij b.v., Amsterdam

Hietbrink, Willem en Ronald Lagendijk, (1994) Kwispelen met taal. Phoenix en Den Oudsten Uitgevers, Rotterdam

Hoogerwerf, A. (1989) 'Het gebruik van de geschiedenis in het beleidsproces', in Geschiedenis buiten de perken. Stichting Leidschrift, Leiden, pp. 63-74

HOOP (1993), Ontwerp Hoger Onderwijs en Onderzoek Plan 1994. Ministerie van Onderwijs en Wetenschappen, Zoetermeer

Houten, Kees van en Marinus Kasbergen (1985) Bach en het getal. Een onderzoek naar de getallensymboliek en de esoterische achtergronden hiervan in het werk van Johann Sebastian Bach. Walburg Pers, Zutphen

Huizinga, Johan (1935) In de schaduwen van morgen. Een diagnose van het geestelijk lijden van onzen tijd. Tjeenk Willink, Haarlem

Huizinga, Johan (1905) 'Het aesthetische bestanddeel van geschiedkundige voorstellingen', in Verzamelde Werken VII. H.D.Tjeenk Willink, Haarlem 1950

Hulspas, M. en B. Nienhuys (1998), Tussen waarheid en waanzin. Encyclopedie van de pseudo-wetenschappen. De Geus, Breda

Ibsch, Elrud, Dick Schram en Gerard Steen (eds.)(1991) Empirical studies of literature: Proceedings of the second IGEL-Conference Amsterdam 1989. Atlanta Editions Rodopi, Amsterdam

Ifrah, G. (1989) From one to zero. A universal history of numbers. Penguin Publishers, Hammondsworth

Ifrah, G. (1994) Histoire universelle des chiffres. L'intelligence des hommes racontée par les nombres et le calcul. Robert Laffont, Paris.

Jaarboek 1994 (1994) NWO Nederlandse Organisatie voor Wetenschappelijk Onderzoek.'s-Gravenhage

Jackendoff, Ray (1996) Taal en de menselijke natuur. Het Spectrum, Utrecht

Jansen, Thijs (1991) 'Het project van de moderne hermeneutiek' in Peter Zeeman (red.) Literatuur en context. Een inleiding in de literatuurwetenschap. SUN/Open Universiteit, Nijmegen, pp. 202-251 
Janssen, Susanne (1991) 'The modus operandi of literary reviewers', in Ibsch, Schram, Steen (eds.) pp. 185-193

Jongh, E. de en P.J.Vinken (1961) 'Frans Hals als voortzetter van een emblematische traditie. Bij het huwelijksportret van Isaac Massa en Beatrix van der Laan', in Oud-Holland 76, pp. 117-150

Katechismus van de Katholieke Kerk (1995) Brussel Utrecht, LICAP en Secretariaat Rooms-Katholiek Kerkgenootschap

Kerstens, J. en A. Sturm (1989) Taalkunde als wetenschap. Nijhoff, Leiden

Kirkham, Richard (1992) Theories of truth. A critical introduction. MIT-press, Cambridge (Mass.)

Kocka, Jürgen (1977) Sozialgeschichte. Göttingen

Koningsveld, Herman (1971) Het verschijnsel wetenschap. Een inleiding tot de wetenschapsfilosofie. Boom, Meppel/Amsterdam

Kool, Marjolein (1999) Die consten vanden getale. Een studie over Nederlandstalige rekenboeken uit de vijftiende en zestiende eeuw, met een glossarium van rekenkundige termen. (diss. Utrecht) Verloren, Hilversum

Korthals, Michiel (ed.) Wetenschapsleer. Filosofisch en maatschappelijkperspectief op de natuur-en sociaal-culturele wetenschappen. Boom, Meppel/Amsterdam

Kossmann, E.H. (1985) De functie van een alphafaculteit in onze maatschappij. Groningen

Koster, Jan (1997) 'Kennis, representatie en reductie', in TABU. Bulletin voor Taalwetenschap 27-2, pp. 57-66

Koster, Jan (1998) 'Gapping moet blijven', in TABU. Bulletin voor Taalwetenschap 28-3,pp. 99-106

Kristeller, Paul Oskar (1979) Renaissance thought and its sources. Edited by Michael Mooney. Columbia University Press, New York

Kuhn, Thomas S. (1962) De structuurvan wetenschappelijke revoluties. Boom, Meppel/Amsterdam 1979

Kunst, J. (1988) Filosofie van de muziekwetenschap. Martinus Nijhoff, Leiden

Laan, Nico (1997) Het belang van smaak: twee eeuwen academische literatuurgeschiedenis. Amsterdam

Lakatos, Imre (1970) Wetenschapsfilosofie en wetenschapsgeschiedenis. De controverse tussen Popper en Kuhn. Boom, Meppel

Lange, Eric de (1995) Sober en solide. De wederopbouw van Nederland 1940-1965. NAi uitgevers, Rotterdam

Langendorff, Ton (1990) De geesteswetenschappen in Nederland: een overzicht. Raad voor Advies voor het Wetenschapsbeleid. Den Haag

Lazarsfeld, Paul (1949) boekbespreking van S.Stouffer et al., The American Soldier. Herdrukt in L. Coser (ed.), The pleasures of sociology New York 1980, pp. 5-7

Levelt, W. (1989) Speaking. From intention to articulation. MIT-press, Cambridge (Mass.), London

Lipstadt, Deborah (1993) Denying the holocaust. The growing assault on truth and memory. The free press, New York, etc.

Lorenz, Chris (1987) De constructie van het verleden. Een inleiding in de theorie van de geschiedenis. Boom Meppel/Amsterdam

Maerlant, Jacob van (1994) Spiegel historiael. Bloemlezing bezorgd door Frits van Oostrom. Amsterdam University Press, Amsterdam

Martin, Raymond (1993) 'Objectivity and meaning in historical studies', in History and theory 32 , pp. 27-46

Mayr, Ernst (1993) One long argument. Charles Darwin and the genesis of modern evolutionary thought. Penguin Books, London 
Menninger, K. (1969) Number words and number symbols. A cultural history of numbers. The MIT-press, Cambridge (Mass.)

Mijnhardt, W.W. en B.Theunissen (1988) De twee culturen. De eenheid van kennis en haar teloorgang. Rodopi, Amsterdam

Miller, David (1985) 'Introduction' in Popper (1985)

Mourits, Bertram en Thomas Vaessens (1997) 'This game is shareware. Internet en de letterkundige neerlandistiek', in Nederlandse letterkunde 2-1, pp. 75-84

Nakamoto, Hideshiro (1988) 'Synchronous and diachronous citation distribution', in L. Egghe and R. Rousseau (eds.) Informetrics 87/88, Elsevier Science Publishers b.v

Nederhof, A.J., R.A. Zwaan, R.E. de Bruin, P.J. Dekker (1989) 'Assessing the usefulness of bibliometric indicators for the humanities and the social and behavioural sciences: a comparative study', in Scientometrics 15-5/6, pp. 423-435

Nierop, Maarten van, Renée van de Vall en Albert van der Schoot (eds.) (1993) Mooie dingen. Over de esthetica van het object. Boom, Meppel/Amsterdam

Nolthenius, Hélène (1989) Een man uit het dal van Spoleto. Franciscus tussen zijn tijdgenoten. Querido, Amsterdam

Nuchelmans, G. (1990) 'Pleidooi voor een ingetogen hermeneutiek', in G. Nuchelmans e.a. (1990), pp.7-14

Nuchelmans, G. e.a. (1990) Tekstinterpretatie. Koninklijke Nederlandse Akademie van Wetenschappen, Amsterdam

Nussbaum, Martha C. (1997) Cultivating humanity. A classical defense of reform in liberal education. Harvard University Press, Cambridge (Mass.) en London

O'Hear, Anthony (1989) Introduction to the philosophy of science. Clarendon Press, Oxford

Orlers, Jan Jansz. (1641) Beschrijvinge der stadt Leyden [...] Leyden [etc.]: voor Andries Jansz. Cloeting

Oostendorp, Marc van, en Ton van der Wouden (1998) 'Digitaal. Corpus Internet', in Nederlandse Taalkunde 3-4, pp. 347-361

Oostrom, Frits van (ed.) (1994) zie: Jacob van Maerlant.

Overwater, A.M. (1994) De tijdgids. Zakkalender voor 16 eeuwen. Uitgeverij Van Wijnen, Franeker

Papineau, David (1993) Philosophical naturalism. Blackwell, Oxford (UK), Cambridge (Mass.)

Parker, Geoffrey (1979) Europe in crisis 1598-1648. Fontana Press, London $1988^{5}$

Pfeiffer, Rudolf (1976) History of classical scholarship from 1300-1850. Clarendon Press, Oxford

Philippa, Marlies, (1992) Woord, ik bemin je. Amsterdam, Thomas Rap

Pinker, Steven (1994) The language instinct. Penguin Books, London etc.

Pinker, Steven (1997) How the mind works. Penguin books, London etc.

Pollmann, Thijs (1995) 'Waarheidstheorieën in de geschiedbeoefening', in Theoretische geschiedenis 22-2, 149-164

Pollmann, Thijs (1997) 'De hermeneutische cirkel en de cognitieve psychologie. Interpreteren en waarnemen in de literatuurwetenschap', in Tijdschrift voor Literatuurwetenschap 2-1, pp. 14-23

Pollmann, Thijs (1998a) 'On forgetting the historical past', in Memory and Cognition 26-2, pp. 320-329

Pollmann, Thijs (1998b) 'The process of cognitive distance: A Quantitative Analysis of some Aspects of Historical Culture', in Historical Social Research 23-4, pp. 79-93

Pollmann, Thijs (te verschijnen) 'Forgetting and the aging of scientific publications' 
Popper, Karl (1965) Conjectures and refutations. The growth of scientific knowledge. Harper\&Row Publishers, New York en Evanston.

Popper, Karl (1967) De armoede van het historicisme. Uitgeverij Het Spectrum, Utrecht/Antwerpen.

Popper, Karl (1976) Unended Quest. An intellectual autobiography. Fontana

Popper, Karl (1985) Popper selections. Edited by David Miller. Princeton University Press, Princeton (New Jersey)

Popper, Karl (1992) In search of a better world. Lectures and essays from thirty years. Routledge, London/New York

RAWB (1990) De toekomst van de geesteswetenschappen in Nederland. Raad van advies voor het wetenschapsbeleid, Den Haag.

Rees, C.J.van en G.J. Dorleijn (1994) 'Literatuuropvattingen in het literaire veld: over de integratie van twee benaderingen', in Spektator 23, pp. 91-114

Reve, Karel van het (1978) 'Het raadsel der onleesbaarheid', in Karel van het Reve, Een grote bruine envelop. Uitgeverij G.A.van Oorschot, Amsterdam 1991, pp. 70-91

Reve, Karel van het (1991) 'Wat waren zij kwaad', in Karel van het Reve, Een grote bruine envelop. Uitgeverij G.A. van Oorschot, Amsterdam, pp. 92-108 (Ook in K.van het Reve, Een dag uit leven van de reuzekoeskoes. Uitgeverij G.A.van Oorschot, 1979)

Reve, Karel van het (1990) De ondergang van het morgenland. Uitgeverij G.A.van Oorschot, Amsterdam

Reijen, Paulvan (ed.) (1994) Muziek en muziekwetenschap in de Nederlandse cultuur. Beschouwingen bij het 125-jarig bestaan van de Koninklijke Vereniging voor Nederlandse Muziekgeschiedenis. KVNM, Utrecht.

Roer, H.van de (1995) Staalkaart geesteswetenschappen. Research voor beleid bv., Leiden

Rorty, Richard (ed.) (1967) The linguistic turn. Recent essays in philosophical method. The University of Chicago Press, Chicago/London

Rosch, Eleanor (1975a) 'Universals and cultural specifics in human categorization', in R.W.Brislin, S. Bochner en W.J.Lonner (eds.) Cross-cultural perspectives on Learning. John Wiley \& Sons, New York etc, pp. 177-206

Rosch, Eleanor (1975b) 'Cognitive reference points', in Cognitive psychology7, pp. 532-547

Ruiter, J.P. de (1995) Ingezonden brief in Hypothese, juni 1995, p. 15

Rummens, Maurice, (1994) 'Van Goghs expressieve onhandigheid', in Jong Holland 10 (4), pp. 27-39

Rupp, Jan C.C. (1991) 'Theatra anatomica. Culturele centra in het Nederland van de zeventiende eeuw', in J.J.Kloek en W.W.Mijnhardt (eds.), De productie, distributie en consumptie van cultuur. Rodopi, Amsterdam, pp. 13-36

Samama, Leo (1994) 'Muziek, wetenschap en maatschappij: enkele filosofische en praktische beschouwingen ter gelegenheid van het 25e lustrum van de VNM', in Paul van Reijen (ed.)(1994), pp. 11-20

Sankey, Howard (1997) Rationality, relativism and incommensurability. Aldershot [etc.], Ashgate

Schama, Simon (1987) 'Dutch landscapes: Culture as Foreground', in P.C.Sutton e.a. Masters of the $17^{\text {th }}$-Century Dutch Landscape Painting. Amsterdam etc., pp. 64-83

Scheen, Pieter A. (1969-70) Lexicon Nederlandse beeldende kunstenaars 17501950. Kunsthandel Pieter A. Scheen NV, 's-Gravenhage ( 2 delen)

Schmidt, Otto (1993) Waar gebeurd? Geschiedschrijving en sociaal-wetenschappelijk onderzoek. Het Spinhuis Amsterdam

Schoenmakers, Henri (1989) Filosofie van de theaterwetenschappen. Martinus Nijhoff, Leiden 
Schoenmakers, Henri (1990a) 'Innovatie in de theatrale kunsten en in de theaterwetenschap', in Fokkema en Ruiter (eds.) Innovatie, pp. 79-109

Schoenmakers, Henri (199ob) 'Between reasonless passion and passionless reason: theatre studies in the nineties', in Zürcher en Langendorff (ed.) The humanities in the nineties, pp.175-205

Schrover, Els (1992) Deconstructie en literatuur. Coutinho, Muiderberg

Schulte Nordholt, Annelies en Jos van Winkel (1995) 'In den beginne was er de literaire tekst. Contra het literatuurwetenschappelijke veld volgens Van Rees en Dorleijn', in Forum der Letteren 36-2, pp. 98-107

Seuren, P.A.M. (1990) Filosofie van de taalwetenschappen. Martinus Nijhoff, Leiden

Steiner, George (1975) After Babel. Aspects of language and translation. Oxford University Press, Oxford

Steinmetz, H.A.(1991) 'Tekstinterpretatie in de literatuurwetenschap', in G.Nuchelmans e.a., pp. 239-244

Stoof, Jan (1995) 'Rembrandt onder de massaspectrometer', in Hypothese maart 1, pp. 14

Thompson, E.P. (1963) The making of the working class. Victor Gollancz ltd., London

Tollebeek, Jo en Tom Verschaffel (1992) Devreugden van Houssaye. Apologie van de historische interesse. Wereldbibliotheek, Amsterdam

Tollebeek, Jo (1994) De IJkmeesters. Opstellen over de geschiedschrijving in Nederland en België. Uitgeverij Bert Bakker, Amsterdam

Vries, G. de (1985) De ontwikkeling van wetenschap. Een inleiding in de wetenschapsfilosofie. Groningen

Vries, Jan de, en F. de Tollenaere (met medewerking van A.J.Persijn) (1991) Etymologisch woordenboek. 16e druk, Het Spectrum, Utrecht

Wal, Marijke van der (in samenwerking met Cor van Bree) (1992) Geschiedenis van het Nederlands. Het Spectrum, Utrecht

Wal, S.L.van der (1971) Officiële bescheiden betreffende de Nederlands-Indonesische betrekkingen 1945-1950, [...] voltooid door P.J. Drooglever en M.J.B. Schouten. Nijhoff,'s-Gravenhage, 1971-1996 (20 delen)

White, Hayden (1992) 'Historical emplotment and the problem of truth', in Saul Friedlander (ed.) Probing the limits of representation. Nazism and the 'final solution, Harvard University Press, Cambridge (Mass.)/London, pp. 37-53

Willemijns, R. (1997) 'Laatmiddelnederlands (circa 1350-1550)', in M.C.van den Toorn e.a. (eds.) Geschiedenis van de Nederlandse taal. Amsterdam University Press, Amsterdam, pp. 147-225

Willems, Gerrit (1993) 'Verklaren en ordenen. Over stijlanalytische benaderingen', in Halbertsma en Zijlmans, pp. 103-144

Woude, A.van der (1972), Het Noorderkwartier. (diss. Utrecht) Utrecht

Zanden, J.L. van en R.T. Griffiths (1989) Economische geschiedenis van Nederland in de zoe eeuw. Het Spectrum, Utrecht

Zoest, Aart van (1978) Semiotiek. Over tekens, hoe ze werken en wat we ermee doen. Ambo, Baarn

Zürcher, E. en T. Langendorff (eds.) (1990) The humanities in the nineties. A view from the Netherlands. Swets \& Zeitlinger, Amsterdam/Lisse

Zijlmans, Kitty (1993) 'Kunstgeschiedenis als systeemtheorie', in Halbertsma en Zijlmans, pp. 311-344 


\section{Index}

Abductie 66

Academie 22; 27

Académie Française 22

Ad hoc 40;104; 158

Adler 144

Afleiding 40; 60 e.v.; 64; 107; 161

Alberti 17

Albertus Magnus 10

Alfavakken passim

Algemene beweringen 56; 57; 60 e.v.; 69; 102; 109; 136; 172

Algemene Nederlandse Spraakkunst 178

Ambiguïteit: zie Dubbelzinnig

Alledaagse kennis 30; 33 e.v.

Analytische zinnen 58 e.v.

Ankersmit, Frank 85; 86; 169

Anti-psychologistische attitude 74;79; 95; $115 ; 126$

Apostel, Leo 123;172

Arabisch 10;14

Aristoteles 10; 20

Artes liberales 9; 10;11; 14; 22

Artisprudentie 195

Arts\& $\backsim$ Humanities Citation Index $140 ; 162 ; 166$

Astrologie 37

Atomaire beweringen 99

Augustinus 10

Auschwitz-Lüge 37; 41

Automatisch vertalen 179

Automatische spraakherkenning 179

Automatisering 72;73;124; 179

Axioma 71

Bacon, Francis 19

Barlaeus 13

Bedrijfsgeschiedenis 181

Begrensde rationaliteit 29; 98; 172

Begrijpen 110 e.v.; 123; zie ook Verstehen
Bewering 56 e.v. en passim

Bibliometrie 141

Bijbel 10;13; 32 e.v.; 92; 121

Boer, Pim den 164 e.v.

Boom van deducties $61 ; 63 ; 104$;

$148 ; 172$

Bronnen passim

Bronnenkritiek 76;165

Brunelleschi 17

Canon 75 e.v.; 194 e.v.

Carnap 26;99; 146

Causale samenhang 68;112

Champollion 164

Chomsky, Noam 161; 180

Cicero 10; 12

Classificeren 23; 28; 117 e.v.

Cliometrie 82 e.v.; 152 e.v.

Cohen, Antonie 80

Coherentie 112; 128 e.v.; 130 e.v.; 158; zie ook Samenhang

Coherentietheorie 112; 130 e.v.; 15

Coherentisme 159

Collier, René 80

Common sense 34 e.v.; 68; 109;

$112 ; 123 ; 127 ; 136$ e.v.

Communicatiekunde 154; 179

Concept 88; 116 e.v.; 122 e.v.; 129; $164 ; 167$

Conceptvorming 116 e.v.; 121 e.v.

Conclusie 59; 65

Connaisseurs 190

Context 80; 90 e.v.; 134 e.v.; 147; en passim

Context of discovery $42 ; 115 ; 157$

Context of justification 42; 115

Correspondentie 60 e.v.; 105; 128 e.v.; 158 e.v.

Correspondentietheorie 105; 111; 130 e.v.; 159

Covering law 108 e.v.
Covering law model 108 e.v.

Creationisme 32 e.v.

Criticus 191 e.v.

Cultural Studies 26

Cultureel systeem 76;190; 192

Culturele rol van een weten-

schap 176 e.v.; 191

Cultuurparticipatie 191

Cultuurwetenschappen 58;114;

171

Dante 16

Darwin, Charles 34

Darwinisme 32; 48

Data passim

Davidson, Donald 52

Deconstructie 49;162

Deductie 60 e.v.; 103

Deductief-nomologisch verklaringsmodel 108 e.v.; 111

Deductieve redenering 60

Definiëren 53

Definities 53

Demarcatiecriterium 30; 118

Dendrochronologie 72

Derrida 40;46; 49; 162; 173

Dialectica 9

Dialectkunde 25;156;179

Dilthey, Wilhelm 23; 113; 174

Dogmatisch $31 ; 43 ; 142 ; 149$

Dogmatisch falsificationisme 146

Donatus 10

Droysen, Johann Gustav 23

Dubbelzinnig 80;134; 138; 147; 158

Dürer, Albrecht 17

Dussen van der, W.J. 130

Economie $23 ; 24 ; 83 ; 84 ; 156$

Editeren $176 ; 181$

Einstein 142 e.v.

Elegantie 70 
Elitecultuur 25

Elton 153

Empirisch 49;59;76; 122; 128;

$135 ; 154 ; 162 ; 165$

Empirische cyclus 103 e.v.

Empirische inhoud 62; 148 e.v.; 172

Empirische literatuurwetenschap 153

Empirische wetenschappen 71; 165

Engerman 82 e.v.

Enquête 79; 83

Epistemologie 137

Erasmus $13 ; 16$

Erklären 113; zie ook Verklaren

Esoterisch 55;180; 192

Essayistiek 41 e.v.

Essayistische kennis 30; 41 e.v.

Essentialisme 47 e.v.; 59

Esthetische waarde 69;195

Ethiek 13

Ethisch relativisme 182 e.v.

Etymologie 39; 40

Euclides 10

Experiment 10; 19 e.v.; 36; 79; 103

Experimentele wetenschappen 74

Explanandum 108

Explanans 108

Expliciteren 55

Extensie 51

Extensieprobleem 51

Fallibilisme 128; 143

Falsificatie 145 e.v.; 167

Falsificatiecriterium 145 e.v.

Falsificationisme 145 e.v.

Feiten 86 e.v.; 103; e.v.; 147 e.v. en passim

Fens, Kees 191

Feyerabend 51

Filologie 11;15; 190

Filosofie passim

Fodor, Jerry 96

Fogel, Robert William 82 e.v.; 152

Fokkema, Douwe 192

Fonetiek 72; 80; 81; 84; 89; 148; 194

Fonologie 117

Formaliseren 54 e.v.
Formele taal 45

Foucault, Michel 46;162;164; 173

Foundationalisme 158

Freud, Sigmund $30 ; 142 ; 162$

Frye, Northrop 88; 192

Galenus 10

Galilei, Galileo 32

Geesteswetenschappen passim

Geformaliseerd taalgebruik 29

Gegevens passim

Geloof 31;32; 44

Generaliserende beweringen 56; 66; 102

Generatieve grammatica 125

Geopenbaarde waarheid 31

Geschiedbeoefening 67;71;77; 99; 109; 126; 137; 152 e.v.; 166;

169; 18 o e.v.; $191 ; 196$

Geschiedfilosofie 27

Geschiedschrijving 67; 85; 181

Geschiedvorsing 67

Gezaghebbende teksten 10

Gezaghebbende publikatie 168 e.v.

Gezond verstand zie: Common Sense

Ghiberti 17

Godsdienstige kennis 30 e.v.

Goudsblom, Joop 24; 195

Grammatica 9 e.v.; 15; 78; 122; 178

Grammaticaliteitsoordeel 77 e.v.

Grice, Paul 53

Grimm, Jakob 107

Groei van kennis 129; 140 e.v.

Haack, Susan 142; 157 e.v.

Haacks rechtvaardigingstheorie 159 e.v.

Hart 't, Hans 80

Hempel, Carl 26;30; 108; 109

Hermeneutiek 92 e.v.

Hermeneutische cirkel 92 e.v.; $112 ; 134$ e.v.

Hineininterpretieren 134

Huizinga, Johan 69; 93; 98; 182

Humaniora passim

Humanisme $11 ; 12 ; 14 ; 18 ; 19 ; 20$; 190

Humanisten 11 e.v.; 16
Hypothese 66

Hypothetisch-deductieve werkwijze 66

Ibsch, Elrud 192

Iconclass 121 e.v.

Iconologie 156

Ideaaltype $85 ; 120$

Idiografisch 24

Images 97

Incommensurabiliteit 151 e.v.

Inductie 60; 65 e.v.; 103; 105

Inductief-statistische verklaring 109

Inductieprobleem 65;129

Inductieve redenering 65

Initiële condities 105; 108

Intensie $51 ; 52 ; 54 ; 100$

Interpretatie 74; 80 e.v.; 90 e.v.; 111 e.v.; 131 e.v.; 148 e.v.; 158

Interpreteren zie: Interpretatie

Intersubjectief 96

Intuïties 77 e.v.; 162

Jongh, Eddy de 132 e.v.; 156; 191 Journalistieke kennis 30; 41 e.v. Justinianus 10

Kennend subject 74; 88; 89; 112; $128 ; 171$

Kennisbeheer 28; 29;195

Kennisproductie28; 29; 595; 64; $125 ; 142 ; 179 ; 195$

Kirkham 130 e.v.; 138

Klankwet 105 e.v.; 143

Kocka 184

Koninklijke Nederlandse Academie van Wetenschappen 122

Komrij, Gerrit 191

Koran 31

Kossmann, E. 177

Kritiek 32; 41; 76; zie ook Kunstkritiek; Open voor kritiek

Kritisch rationalisme 143

Kruiswoordpuzzle 157

Kuhn, Thomas 51; 142; 150 e.v.; 164

Kunstgeschiedenis 17;73;75;81;

$82 ; 121 ; 137 ; 156 ; 196$

Kunstkritiek 76;191 e.v.

Kunstmatige taal 45

Kunstvakken 76;175;190 
Kunstwetenschappen 24;75; 166; 190 e.v.

Kwantificeren 80; 82 e.v.; 166 e.v.

Kwantitatief 79; 83; 140; 152 e.v.; $156 ; 166 \mathrm{e}, \mathrm{v}, ; 171$

Lakatos, Imre 142; 152; 154 e.v.

Latijn 10 e.v.; 16 e.v.; 21

Lazarsfeld, Paul 35 e.v.

Leonardo da Vinci 17

Letteren passim

Letterkunde $11 ; 17 ; 21 ; 22 ; 73 ; 75$; 85; 175; zie ook Literatuurwetenschap

Lingua franca 17

Linguistic turn 46

Lipsius, Justus 13

Literatuurgeschiedenis $141 ; 154$

Literatuurwetenschap 122; 135; 149; 190; zie ook Letterkunde

Logica $9 ; 13 ; 45 ; 63 ; 71$

Logica van de situatie 125

Lorenz, Chris 50; 130

Mach, Ernst 99

Marly 172

Marx, Karl 30; 142 e.v.; 162

Massacultuur 25; 173

Medicijnen 9 e.v.; 13; 24

Methode 42; 46;114; 166

Methodologisch falsificationisme 145 e.v.

Model 123 e.v.

Musicologie 72; 75; 190

Muybridge, Eadweard 88

Muziekwetenschap zie: Musicologie

Mythologische kennis 33; 43

Narratieve substanties $85 ; 86$

Narratologie 122

Natuurgeneeswijze 37

Natuurlijke taal 45

Natuurwet 28

Natuurwetenschappen 14;19 e.v.; $23 ; 27 ; 141 ; 161 ; 174$

New economic history 82

Newton, Isaäc 19

Nomothetisch 23;24;102

Objectief $95 ; 98 ; 143 ; 146 ; 148$; $151 ; 159 ; 171$

Observatie 72; passim
Observatietermen 99

Onbevangen waarneming 89;

95

Onderzoeksprogramma’s 154

e.v.; 168

Open voor kritiek 56;143; 149

Openbaring 31 e.v.

Operationaliseren 54

Otten, Willem Jan 41;191

Panofsky, Erwin 156

Paradigma 151 e.v.; 168

Parapsychologie 37

Popper, Karl 26;30; 104; 110; 125 e.v.; 142 e.v.; 154

Positivisme 23

Postmodernisme 166; 173

Predictie 107

Primaire gegevens 76;77

Principe van rationaliteit; 52 e.v.; 96; 127; 128

Principe van welwillendheid 52; 96

Probleem-georiënteerd

Probleemstelling 160;193

Proefpersonen $74 ; 77 ; 80$

Propedeuse 9;14

Protocolzinnen 99

Prototypietheorie 48

Pseudo-etymologie 38

Pseudo-geschiedbeoefening 37

Pseudo-musicologie 38;40

Pseudo-wetenschappen 30;37

e.v.; 44

Psycholinguïstiek 125;154

Putnam, Hilary 130

Quadrivium 9

Rationaliteit $28 ; 51 ; 69 ; 116 ; 125$; $128 ; 140 ; 145 ; 174 ; 184 ; 185 ; 193$

Rationaliteitsprincipe zie: Principe van rationaliteit

Rechten 9 e.v.; 13; 15; 21

Rede 28; zie ook Rationaliteit

Redenering 59 e.v.; passim

Reductionisme 21

Reformatie 12

Regelmaat 66

Relativisme 51;151 e.v.; 161

Religieuze kennis 30 e.v.

Rembrandt 195

Renaissance 12;190
Retorica 9 e.v.

Retrodictie 107

Reve, Karel van het 193

Rickert, Heinrich 24

Rijksinstituut voor Oorlogsdocumentatie (RIOD) 176

Rockbottom of knowledge 146 e.v.

Rosch, Eleanor 48

Royal Society 22

Russell, Bertrand 99

Samengestelde feiten 80

Samenhang 68 e.v.; 131 e.v.; passim

Scaliger, Joseph 14; 15

Schama, Simon 138

Schleiermacher 92

Schoenmakers, Henri 140

Schönberger, Helmer 191

Secundaire gegevens 78

Singuliere beweringen 57;60;

$68 ; 172$

Situational logic 125 e.v.

Situationslogik 125 e.v.

Snow, C.P. 174

Sociale wetenschappen $22 ; 84$;

$141 ; 161 ; 165 ; 176 ; 185$

Sociolinguïstiek 156

Sokal, Alan 162; 166

Spengler, Oscar 110

Spraaksynthese 179

Statistische methodes $39 ; 84$

Statistische uitspraken $58 ; 81$;

108

Stevin, Simon 16 e.v.

Stilistisch onderzoek 82;120

Structuralisme 117

Studia humanitatis 11 e.v.

Stijl $81 ; 120$

Stijlanalyse $81 ; 82 ; 120$

Synthetische zinnen 58

Taalfilosofie 46

Taalkunde 18; 22; 24; 73; 77 e.v.;

$81 ; 141 ; 149 ; 175 ; 177$ e.v.; 195

Taalkundige expertise 177 e.v.

Taalonderwijs 179

Taalzorg 178

Talige vorm van kennis 45 e.v.

Technische rol van een weten-

schap 176 e.v.; $180 ; 190$

Teksten 67 e.v. 
Tekstkritiek 12; 18

Tekstlinguïstiek 154

Theaterwetenschap 140

Theologie 9 e.v.; 13; 21; 31

Theoretisch kader 63

Theoretische termen 99 e.v.

Theorie passim

Theoriegeladen 48; 96 e.v.; 101; 122; 171

Thomas van Aquino 10;31

Thompson, E. 119

Toetsen $43 ; 60 ; 63 ; 64 ; 71 ; 103$;

104; 106; 207; 227 e.v.; 129; 149

Toeval $38 ; 39 ; 83 ; 84$

Triviale kennis 34 e.v.

Trivialiteiten $34 ; 66 ; 102 ; 128 ; 137$

Trivium 9

Twee culturen 21;174

Ufologen 37

Uniek 24; 57; 58; 114; 116 e.v.; 171; 193

Unificatie 15;104

Universele grammatica $156 ; 161$

Universiteit 9;10;13;21;22; 27

Vakjargons 53; 55; 192

Vergelijkende Indo-europese

Taalwetenschap 155
Verificatie $129 ; 145$

Verificationisme $145 ; 158$

Verklaren 102 e.v.; 108; passim

Vermoeden passim

Verstehen 110 e.v.; 136 e.v.; 172; 193

Vertaalprobleem 50; 99

Vinken, Pierre 132 e.v.; 156

Volkskunde 25

Volkstaal 16

Voorspelling 20;103;107;108

Vossius, Gerard 13

Vries, Gerard de 58; 130

Vrouwengeschiedenis 25

Vrouwenstudies 123

Waardegeladen 24;55

Waarden 193

Waardeoordeel 193 e.v.

Waardeprobleem 50;99

Waardevrijheid 193 e.v.

Waarheid 128 e.v.;; passim

Waarheidsaanspraken 28; 43; 182

Waarheidstheorie 105

Waarnemen 90 e.v.; passim

Waarneming 9o e.v.; passim

Waarnemingsprocessen 91 e.v.; 146
Waarnemingstechnieken $72 ; 88$

Waarnemingsvermogen 89 e.v.; $138 ; 159$

Waarschijnlijkheidsuitspraken $58 ; 66 ; 108$

Waarschijnlijkheidsweten 172

Wagner, Richard 110; 111

Walry, Jenny 123

Weber, Max 85; 120

Welwillendheidsprincipe zie

Principe van welwillendheid

Wetenschappelijke kennis 30

e.v.; passim

Wetenschappelijke methode 23

Wetenschapsfilosofie 26; 27; 58 ;

$140 ; 142$

Wetenschapsgeschiedenis 27

Wetenschapssociologie 27

Wetenschapstheorie 27

Wetering van de, Ernst 114

Wetten 102; 108 e.v.

Wiener Kreis 26

Windelband, Wilhelm 23

Wiskunde 14; 19; 20; 21; 45

Wittgenstein, Ludwig 99

Woordbetekenis 47;51;96;171

Zekerheid 62 e.v.; passim 